\title{
Van gangbaar tot problematies drankgebruik
}

Citation for published version (APA):

Knibbe, R. A. (1984). Van gangbaar tot problematies drankgebruik. [Doctoral Thesis, Maastricht University]. Rijksuniversiteit Limburg. https://doi.org/10.26481/dis.19841005rk

Document status and date:

Published: 01/01/1984

DOI:

10.26481/dis.19841005rk

Document Version:

Publisher's PDF, also known as Version of record

\section{Please check the document version of this publication:}

- A submitted manuscript is the version of the article upon submission and before peer-review. There can be important differences between the submitted version and the official published version of record.

People interested in the research are advised to contact the author for the final version of the publication, or visit the DOI to the publisher's website.

- The final author version and the galley proof are versions of the publication after peer review.

- The final published version features the final layout of the paper including the volume, issue and page numbers.

Link to publication

\footnotetext{
General rights rights.

- You may freely distribute the URL identifying the publication in the public portal. please follow below link for the End User Agreement:

www.umlib.nl/taverne-license

Take down policy

If you believe that this document breaches copyright please contact us at:

repository@maastrichtuniversity.nl

providing details and we will investigate your claim.
}

Copyright and moral rights for the publications made accessible in the public portal are retained by the authors and/or other copyright owners and it is a condition of accessing publications that users recognise and abide by the legal requirements associated with these

- Users may download and print one copy of any publication from the public portal for the purpose of private study or research.

- You may not further distribute the material or use it for any profit-making activity or commercial gain

If the publication is distributed under the terms of Article $25 \mathrm{fa}$ of the Dutch Copyright Act, indicated by the "Taverne" license above, 


\title{
VAN GANGBAAR TOT PROBLEMATIES DRANKGEBRUIK
}

\section{Proefschrift \\ ter verkrljging van de graad van doctor in de Sociale Wetenschappen \\ aan de Rljksuniversitelt Limburg,}

op gezag van de Rector Magniflcus Prof.Dr. H.C. Hemker, volgens beslult van het College van Dekanen

in het openbaar te verdedigen

op vrljdag 5 oktober 1984 des naniddags on 16.00uur precies

\author{
door \\ Ronald Amold Knibbe \\ geboren te Amsterdam in 1947
}


Promotor: Prof.Dr. Maria J. Drop

Referenten: Prof.Dr. J. Casselman

Prof.Dr. F. Sturmans 

Manuscrlpt: Sylvia Nelk Figuren: Ger van Wunnik Ontwerp onslas en foto: Frank van Helfteren Druk: Ben Meerstad 
De uitvoering van de onderzoeken waarvan in deze studie de gegevens worden gebrufikt berustte bif twee Instellingen, namelijk de Rijksuniversiteit Limburg, capaciteltsgroep Medische Soc1ologie en de G. G. \& en G. D. - Rotterdam, afdeling G.V.O.

Deze onderzoeken zijn mogelifk genaakt door subsıdies van het Ministerle van Volksgezondheid en M1lieuhyglëne, van het preventlefonds, van de gemeente Rotterdam, de Provinclale Staten van Limburg en de Rijksuniversiteit Limburg.

De publikatie van dit proefschrift is mede mogelijk gemaakt door een subsidie van de Stichting Alkohol Fonds. 


\section{INHOUDSOPGAVE}

HOOFDSIUK

Inleiding

Deel I: Probleemstellingen, theorle en hypothesen

I: $\quad$ Probleemstellingen

I.1.: Enkele begrippen

I. 2.: Drankgebruik en soclale kontrole:

een nadere omschrifving

I. 3. : Normatleve opvattingen

I. 4.:

Probleemstelilingen

II. : Gangbare drinkpatronen

II. 1. : Drankgebrutk als gewoonte, drinkpatronen

II.2.: Roltheorie: een nadere plaatsbepaling van drankgebrulk

II.2.1.: Statusrollen

II.2.2.: Positierollen

II. 3.1.: : Statusrol en drinkpatroon

II.3.2. : Statusgroeperingen die verschtllen in gangbaar drinkpatroon

Samenvatting

III. : Intensivering van drankgebrulk

III. 1. : Inleiding

III. 2. : Geheelonthouding

III. 2. 1. : Statuskemmerken en geheelonthouding

III.3.1.: Roltheorie en kondities die lelden tot intensivering van drankgebrulk

III. 3.2.: Werksituatie

III. 3. 3. : Gezinssituatle 
IV: Nadelige gevolgen van drankgebrulk, zorgen en afkeuring

IV. 1. : Gevolgen van drankgebrulk:

IV.2.1.: Drinkpatroon

IV. 2.2.: Drinkgeschledenis

52

IV.2.3.: De sociale situatie

52

IV.3. : Afkeuring van of zorgen over

drankgebrulk

IV. 3. 1.: Begripsomschrijving en de relatie

van nadelige gevolgen met afkeuring

54

IV.3.2.: Gangbaar drinkpatroon

54

IV.3.3.: Drinkgeschledenis

55

IV. 3. 4. : Soclale situatie

56

Samenvatting

Deel II Onderzoek

V.:

De gebrutkte onderzoeken: betrouwbaarheld en geldigheld van konsumptiegegevens

V.1.: $\quad$ Steekproeven en veldwerk

V.2.: Betrouwbaarheid en geldigheld van

gegevens over alkoholkonsumptle

V. 3. : Non-respons als bron van onderschatting

V. 4. : Onderrapportage

V. 4.1.: Onopzettelljke onderrapportage

V.4.2.: Opzettel1jke onderrapportage

V. 5 .

Konklusle

VI. : Drinkpatronen en verschillen tussen statusgroeperingen

VI. 1.: Inleiding

VI. 2.: Drinkpatronen

VI.2.1.: Opzet van de analyse

VI.2.2.: Beschrifving van drinkpatronen

Verschilien in drinkpatroon

tussen statusgroeperingen

Samenvatting 
VII.: Faktoren van invloed op intensivering van drankgebruik

VII. 1.: Inlelding

VII.2.: Konstruktie van de variabele

'strukturering van het dagelljks bestaan' 89

VII.2.2. : Opzet van de analyse

VII.3.1.: Verschillen in alkoholkonsumptle naar gelang werk- en gezinssituatie

VII. 3.2.: Verschillen in alkoholkonsumptie naar gelang werk- en gezlnssituatie

VII. 4. : Invloed van al dan niet dagonderwijs

VII. 5. : Gemeentegrootte

VIII. : Gangbaar drinkpatroon en nadelige gevolgen van drankgebrulk

VIII. 1.: Operationalisering van nadelige gevolgen van drankgebruik

VIII. 2. : Relatle van drinkpatroon met nadelige

VIII. 3. : Resultaten

IX. : Faktoren van invloed op

$$
\text { nadelige gevolgen }
$$

IX.1.: Inlelding

IX.2.1.: Invloed van statusfaktoren op de skore op de index

IX.2.1.1.:Verschillen tussen mannen en vrouwen

IX.2.1.2.:De Invloed van leeftijd en soctale klasse bij mannen en vrouwen

IX.2.2.: Gewenning

IX.2.3.: De invioed van strukturering van het dagelijks leven

IX.3. : Strukturering van het dagel1jks

leven en nadelige gevolgen:

een nadere analyse

Samenvatting/diskussie 
X. : Zorgen over en afkeuring van drankgebrutk

X. 1.: Inleiding

X. 2.: Indicering van zorgen over en afkeuring

X.3.: : Resultaten

X. 4.: : Fen nadere analyse

Samenvatting/diskussie

XI.: $\quad$ Samenvatting en slotbeschouwing

XI.1.: Samenvatting van de studie

XI. 2.: Ind1katoren voor strukturering

van het dagelifks bestaan

XI. 3. : Dorzakell jkheld en geldigheld van

XI. 4. : Enkele beleidsoverwegingen

Summary

L1teratuur

B1flage I: tabellen

B1jlage II: logitanalyse

B1Jlage III: vragenlifst

Dankwoord

XLV

Curriculum V1tae

XIVII 
DEEL I: PROBIEEMSTEITINGEN, THEORIE EN HYPOTHESEN 



\section{INLEIDING}

Het gebruik van alkoholhoudende drank behoort in onze samenleving tot de alledaagse gedragsmogelijkheden die nauwel1 jks of niet tegenover anderen gerechtvaardigd hoeven te worden. Volwassen Individuen kunnen een in eerste instantie vanzelfsprekend recht laten gelden op het gebrulk van alkoholhoudende drank. Dat wil zeggen een stof die gedrags- en bewustzijnsveranderende werking heeft. Fen stof ook die op velerlel wifze schadelifk kan zijn voor een geordend verloop van sociale processen; onder andere door schade aan de gezondheld, verslechterde relaties, ongelukken, agressie, e.d.

op zijn minst kan gesteld worden dat er sprake is van een spanningsveld tussen enerzijds een vanzelfsprekend recht van Individuen am alkoholles drank te gebruiken en anderzijds de schadelijke gevolgen voor individu en samenleving die uit dit gebrutk kumen voortvloelen. Dit spanningsveld moet onontkoombaar worden geacht voorzover en voorzolang drankgebruik tot de legltieme gedragsmogelljkheden behoort. Anders gezegd: vanult het nivo van de samenleving bezlen, is het onmogel1jk een konsumptientvo aan te geven waarblj geen schadelijke gevolgen van drankgebruik voor individu of samenleving optreden. (Bruun, e.a.,1975; de Lint 1976, Frankel, Whitehead, 1981).

In deze studie zal alkoholgebrulk vanutt een soclologiese optiek worden beschreven. Centraal staan twee onderling nauw verwante aspekten van drankgebrutk als soclaal verschifnsel: enerzljds de manier waarop in een samenleving drankgebrulk tot de vanzelf'sprekende gedragsmogel1 Jkheden behoort, anderzljds de soclale processen waardoor alkoholgebmutk een verschljnsel wordt dat negatieve reaktles oproept bif de soclale ongeving of bif de drinker zelf. Kortom, het proces van gangbaar tot problematies drankgebruik vormt het hoofdthema van deze studie.

B1f de beantwoording van de probleemstellingen die binnen dit thema worden ontwlkkeld, zullen gegevens gebrulkt worden van twee vrljwel identleke surveys naar probleendrinken in respektlevelijk de provincle Limburg en de gemeente Rotterdam.

Over belde onderzoeken is reeds gepubliceerd. Onder andere 
In dr1e rapporten (Garretsen, 1982, Knibbe 1982; Garretsen, Knibbe, 1983) en een dissertatie (Garretsen, 1983).

De hier te presenteren studie onderscheldt zich in negatief opzlcht van voorgaande publikatles door het feit dat de prevalentiebepaling van probleemdrinken niet centraal staat. In positlef opzlcht onderscheldt deze studie zich van eerder genoemde publikatles doordat systematles en diepgaander het thema van gangbaar tot problematies drankgebruik wordt ultgewerkt. 


\section{Probleemstellingen}

\section{1. Enkele begrippen}

Het begrip drankgebruik behoeft naar ik aanneen niet nader omschreven te worden. Gezien het felt dat de meeste Nederlanders regelmatig alkoholiese drank gebrulken of hebben gebrulkt hoeft over drankgebmiik, ook zonder formele definitie, geen misverstand te bestaan.

Tot de kategorle alkoholgebruikers of "drinkers" worden hier diegenen gerekend die het laatste half jaar minstens één keer één (standaard) glas alkoholhoudende drank hebben gedronken. De kategorie geheelonthouders is daarmee ook omschreven: het zi.jn diegenen die gedurende zes of meer maanden voorafgaand aan het interview geen alkoholhoudende drank hebben gekonsumeerd.

Binnen de soclologiese traditie, kan het thema van gangbaar tot problematles drankgebrulk gezlen worden als een probleem van soclale kontrole.

Met een variant op de door Mok en de Jager (1978) als 'klasslek' bestempelde definitle van soclale kontrole zou ik dit begrip willen amschrifven als de in een samenleving te onderscheiden kulturele en strukturele elementen en gedragingen die er toe bljdragen dat soctale processen ordelijk verlopen. Bezlen vanult het perspektlef van soclale kontrole, zljn de volgende dimensies aan alkoholgebrulk te ondersche1den:

- de wljze waarop het in een samenleving nomaal geachte drankgebrulk is ingerlicht,

- de konditles die leiden tot drankgebruik met nadelige gevolgen voor de drinker of voor zljn soclale omgeving,

- de kondities die ertoe bijdragen dat drankgebrulk of de gevolgen ervan afkeuring in de soctale omgeving van de drinker oproepen of zorgen bif de drinker zelf.

Deze drle perspektieven liggen in elkaars verlengde en vullen elkaar aan. De kondities waaronder drankgebrulk een maatschappelijk aanvaard verschifnsel is, worden beschreven vanult het eerste perspektief. De faktoren die samenhangen 
met de effektiviteit van soclale kontrole, in de betekenis van het voorkơmen van nadelige gevolgen, worden vanult het tweede perspektlef toegelicht. De kondities die ertoe bijdragen dat drankgebrulk als drankmisbrulk wordt gezien, worden vanuit het derde perspektlef beschreven.

Met name vanult het tweede perspektief, het voorkómen van schadelijke gevolgen, en het derde perspektlef, het def1nièren van drankgebrulk als drankmisbruik, doet zich de vraag voor in hoeverre normatleve opvattingen over drankgebrulk en 'alkoholisme' een belangrljk element van soclale kontrole zifn. Meer toegespitst moet ten eerste de vraag gesteld worden of er soclale normen zijn aan te wijzen die het drinkgedrag van individuen op effektleve wijze dusdanig beperken dat de kans op schadelifke gevolgen minimaal 1s. Ten tweede de vraag of er opvattingen over 'alkohollsme' zijn die b1jdragen aan herkenning van schadelljk drankgebruik door de drinker zelf en door de soclale omgeving.

Deze vragen wil $1 \mathrm{k}$ in dit hoofdstuk al stellen en globaal beantwoorden omdat het antwoord richtinggevend is voor de WIJze waarop het thema wordt ultgewerkt. In de hlemavolgende paragraaf zal eerst precleser aangegeven worden op welke aspekten van de soclale kontrole van drankgebruik $1 \mathrm{k}$ me zal richten. Daarna zal ingegaan worden op de normatleve opvattingen.

In de laatste paragraaf van dit hoofdstuk zullen de probleemstellingen worden geformuleerd.

I.2. Drankgebmitk en sociale kontrole: een nadere amschrijving

In deze studie zullen niet alle aspekten van de soclale kontrole van drankgebrulk aan de orde gesteld worden. Zo wordt de bifdrage van de gezondheldszorg aan het voorkómen, herkermen of behandelen van nadelige gevolgen van drankgebrulk hier niet besproken (W1lktns, 1974; Edwards e.a. , 1973; Knibbe, 1982; Knibbe en Meyers 1983).

ook op het aandeel van het justitieel apparaat in het voorkómen of beperken van schadelijke gevolgen van drankgebrutk (Edwards e.a., 1973; Casselman, 1980; Kntbbe en Meyers, 1983), wordt niet Ingegaan. Eveneens bulten beschouwing bl1jft het aandeel dat de overheld heeft in de soctale kon- 
trole van drankgebrulk door konsumptlebeperkende maatregelen als accijnsen, openingstijden van café's, vergunningenstelsel, leeftijdsgrenzen, e.d. (Popham e.a. 1976; Garretsen, Knibbe, 1983).

Hoe belangr1jk deze vormen van soclale kontrole ook geacht kunnen worden, ze geven welnig of geen inzlcht in de wifze waarop drankgebrulk van een vanzelfsprekend recht tot een omstreden gewoonte wordt. Konsentratie op de drinker en relevante anderen uit zijn leefongeving laat toe precleser te beschrifven hoe drankgebrulk tot een probleem wordt.

De konsentratie op dit aspekt van soclale kontrole kan, behalve met wetenschappelijke redenen, ook met meer praktlese redenen worden gemotiveerd. U1t onderzoek van Hingson e.a. $(1980,1982)$ en Mulford (1977) blijkt dat één van de voornaamste impulsen on het drinkgedrag te veranderen -met of zonder professlonele hulp- is dat het drankgebrulk door mensen in de direkte omgeving -partner, vrienden, kollega's e.d. - als probleem wordt ervaren. Derhalve moet aan de sociale kontrole zoals die in de direkte angeving van de drinker verankerd ligt, een belangrljke rol worden toegekend in het voorkómen of herkennen van schadel1.jke vormen van drankgebruik en in de motivatle om het drinkgedrag te veranderen.

I. 3. Normatleve opvattingen

In deze paragraaf zal antwoord gezocht worden op de vraag of normatleve opvattingen van de drinker en van mensen in zijn angeving een belangrifk element van soclale kontrole zijn. De in een samenleving heersende opvattingen over alkoholgebrulk worden in hoge mate gekermerkt door ambivalentie (Phtllpsen 1980, Philipsen e.a., 1983, 1984). Deze amblvalentle tegenover drankgebrulk is zowel struktureel als kultureel verankerd. Struktureel ondat b1 Jvoorbeeld enerz1jds de rljksoverheld drankgebrulk toelaat en er fors aan verdient (Tempel, 1977), anderzljds dlezelfde rijksoverheld van mening is dat initiatieven on de schadelijke gevolgen van drankgebrulk te beperken wenselijk zijn (Garretsen en KnIbbe, 1983). Kultureel omdat er diskrepantle 1 s tussen drinkgedrag enerzilds en opvattingen over drankgebmuik ander$\mathrm{zljds}$.

Bljzonder goed laat dit laatste zich 1llustreren met het 
gegeven dat in Limburg $79 \%$ en in Rotterdam $83 \%$ van de respondenten van mening is dat alkoholgebmulk meer kwaad dan goed doet. En dat terwljl verreweg de meerderheld van deze respondenten zelf regelmatig drinkt.

Deze struktureel en kultureel verankerde amblvalentle geeft de kontekst aan waarin de vraag of nomatleve opvattingen over drankgebrulk bijdragen aan het voorkómen of herkennen van schadel1jk drankgebrulk gesteld moet worden. Immers, gegeven de mate waarin ook drinkers vinden dat drankgebmulk meer kwaad dan goed doet, kan verwacht worden dat er mechanlsmen zifn waardoor drinkers het eigen drinkgedrag als onschuldig kunnen blljven beschouwen.

Fén van deze mechanismen is de vanzelfsprekendheld waarmee drankgebrulk is ongeven, wardoor drinkgedrag (te onderschelden van de gevolgen van drankgebmulk) aan normering wordt onttrokken. Gadourek (1963) merkte al op dat het al dan niet drinken nauwelijks aan normatieve verwachtingen onderhevig 1s. Recenter komt Schippers (1981) tot de konklusle dat 'drinknormen bepalen waar en wanneer men drinkt, nauwelijks of niet echter hoeveel men drinkt'. Ik heb mifn twiffels of er sprake is van algemeen geldende normatieve verwachtingen over waar en wanneer men drinkt, ik ben het echter eens met het belangrijkste onderdeel van Schippers konklusle: ten aanzien van de hoeveelheden die men per keer drinkt bestaan er nauwelijks normatieve opvattingen.

In de onderzoeksgegevens van Limburg en Rotterdam komt dat op een verrassende wi fze naar voren. Er zijn in deze onderzoeken vragen gesteld aan de respondent blj hoeveel glazen de partner of beste vrlend(In) zou vinden dat de respondent teveel zou drinken op respektlevelljk een doordeweekse en een weekenddag.

Een zeer hoge percentage van de respondenten met partner - te weten $42 \%$ in Limburg en $44 \%$ in Rotterdam- weet in het geheel geen antwoord te geven op de vraag wanneer hun partner zou vinden dat ze teveel zouden drinken op een doordeweekse dag. Een nog hoger percentage van alle respondenten -respektleve$11 . j k$ 73\% en $71 \%$ in Limburg en Rotterdam- kan geen antwoord geven op de vraag bij hoeveel glazen hun beste vrlend(in) zou vinden dat ze teveel drinken op een weekenddag. $\mathrm{Er}$ bestaan met andere woorden nauwelljks gedeelde normatleve opvattingen over de hoeveelheden drank die men op een doordeweekse of weekenddag mag drinken. Het ontbreken van deze 
normatieve verwachtingen kan als eerste argument aangevoerd worden on geen grote warde te hechten aan normen als element waarmee schadel1 jk drankgebrulk wordt voorkomen.

$\mathrm{Nu}$ stelt Schippers $\infty \mathrm{k}, 0$. a. In navolging van Gadourek, dat 'drinknormen sterk verbledend zijn met betrekklng tot de schadelijke fysieke, materiele en soclale gevolgen van alkoholgebrulk'. En Inderdaad, vergelljking van de gegevens van LImburg en Rotterdam ult 1981 met gegevens van Gadourek ult 1958, 111ken er op te duiden dat gevolgen van drankgebrutk in 1958 en 1981 in even sterke mate afkeuring oproepen. Zo antwoordde in $195898 \%$ van de respondenten ult de landel1jke steekproef van Gadourek dat ze het 'erg zouden vinden als een famillelid ledere week dronken zou z1Jn' Anno 1981 is nog steeds $95 \%$ van de bevolking in Limburg en Rotterdam dezelfde mening toegedaan (Garretsen, Knibbe 1983). Toch zifn er goede redenen on te twiffelen aan de effektivitelt van deze norm wat betreft het voorkómen van dronkenschap. Tussen 1958 en 1981 is de konsumptle per hoofd van de bevolking in Nederland meer dan verdrlevoudigd. Deze st1jging van de gemiddelde konsumptle kan zelfs niet voor een klein deel worden toegeschreven aan een afname in die perlode van het percentage geheelonthouders. Integendeel het percentage geheelonthouders is b1 mannen stablel; b1j vrouwen is er zelf's sprake van een slgniflkante toename van het percentage geheelonthouders tussen 1958 en 1970 (van Reek, e.a. 1983, Philipsen e.a., 1983). Dit betekent dat de konsumptie per hoofd van de drinkende bevolking in deze perlode fors is toegenomen.

$\mathrm{Nu}$ is herhaaldel1 jk bevest1gd dat er een sterk verband is tussen de gemlddelde konsumptie per hoofd van de bevolking en het aantal excessleve drinkers, meestal gedefinleerd als mensen die 8 of meer glazen gemiddeld per dag drinken(Lederman, 1964; de Lint, Schmidt, 1968, Bruun e.a., 1975), en Nederland is hler geen ultzonderlng op (Knlbbe, 1984). D1t betekent dat het aantal drinkers dat regelmatig dronken 1s, tussen 1958 en 1981 meer dan verdrlevoudigd 1s. En dit ondanks de in 1958 en 1981 nagenoeg even sterk negatieve waardering van dronkenschap. Als tweede argument om nlet teveel waarde te hechten aan normen als element van soclale kontrole kan dan ook aangevoend worden dat zelfs sterk gedeelde en stablele normen nauwel1jks of niet b1jdragen aan het voorkómen van regelmatige dronkenschap dan wel aan de beperking van de groep die regelmatig dronken is. 
Nu kan men zlch afvragen of dan nlet minstens wat betreft het expliclet en nadrukkel1,jk herkennen van drankmisbruik als alkohollsme konkrete en gedeelde opvattingen bestaan in een bevolking. Ook hlerop moet het antwoord naar mifn mening ontkennend zifn. Het valt integendeel julst op dat zelfs verschl Jnselen die duldeli Jk wljzen op excesslef en risikovol drankgebrulk-b1 Jvoorbeeld twee maal per week een kater, drank nodis an verdrlet te vergeten, ruzle met familie over drinken- door. slechts een minderhe1d van de bevolking in Llmburg en Rotterdam gezlen worden als tekenen van alkohollame (Garretsen, Knibbe 1983).

Antons en Schulz (1976) komen op grond van soortgel1jke bevindingen dan ook tot een op het eerste oog verrassende, echter plausibele konklusie. Z1j stellen dat de opvattingen over alkohollsme niet gezlen moeten worden als een element dat als funktie heeft drankmlsbrulk te herkennen, maar integendeel dat 1... dle Starke Distanz zum Alkoholikerb11d, das welt ausserhalb des elgenen Selbstb1ldes und Iebensst1les llegt, Permissivitat im elgenen Trinkverhalten unterstutzt...... Een derde argument on aan normatleve opvattingen geen grote rol toe te kennen als element van soclale kontrole is derhalve dat de opvattingen over alkohol Isme in een samenleving, eerder begrepen moeten worden als rechtvaardiglng van de gangbare vormen van drankgebrutk, dan als b1 jdrage aan herkenning van excesslef drankgebrulk als schadelijk voor individu en/of samenleving.

De genoemde argumenten $\mathrm{zljn}$ de reden waarom in deze studie verder geen aandacht gegeven wordt aan normatleve opvatt ingen. Voorgaande wil echter niet zegsen dat $1 \mathrm{k}$ van mening ben dat ultgesloten kan worden dat normatleve opvattingen een b1 jdrage leveren aan het voorkómen of herkernen van drankmisbrulk. Wel ben $1 \mathrm{k}$ van mening dat onderzoek naar nomen of opvattingen over alkohollsme anders opgezet dlent te worden dan mu veelal gebeurt an dit te kumnen aantonen.

Zo zou ondermeer nagegaan moeten worden welke relevante anderen de meeste Invloed hebben op de grenzen die het individu zelf stelt aan zifn drankgebrutk (Blddle, e.a. 1980), en wat de relatie is tussen de opvattingen van het individu over toelaatbare hoeveelheden en z1Jn feltel1 jk drinkgedrag in verschlliende drinksituaties (Bruun, 1959; Skog, 1979). Dok de gedrags- en persoonl1jkheldskemerken die men aan 'alkoholisten' toeschrljft zouden onderzocht moeten worden (Mc. KIman, 1977, 1978). 


\section{4. Probleemstellingen}

De konklusie van voorgaande paragraaf kan ook als volgt worden geformuleerd: een meerderheld van de bevolking 1 s van mening dat alkohollese drank meer kwaad dan goed doet, enlgszins konkrete en adekwate opvattingen over drankmisbrulk zijn er echter niet of nauwelijks.

Naar mijn mening is de daarmee gepaard gaande onduidel1Jkheld of onentgheld in een samenleving over de grens tussen drankgebruik en drankmisbrulk nlet op te heffen.

De verantwoordelifkheid voor drankgebrulk wordt namelijk in de eerste plaats door de soclale omgeving aan de Individuele drinker zelf toegekend. Anders gezegd: de individuele drinker heeft tot op grote hoogte het recht om bemoelenis van anderen met zijn drinken af te wijzen. In het verlengde hiervan moeten de nomatieve opvattingen van drinkers meer gezlen worden als rechtvaardiging van hun drinkgedrag, dan dat deze opvattingen het drinkgedrag beperken. Van hierult bezlen treft het dan ook niet als verrassend dat er een sterke negatleve samenhang is tussen de bereldheld symptomen van excesslef drankgebrulk als tekenen van alkohollsme te zlen en het konsumptienivo (Knibbe 1982; Garretsen 1983). Toch is er een punt waar de sociale ongeving van de drinker het recht neemt om het drankgebmulk af te w1jzen. Daarb1j wordt het feit dat nadelige gevolgen van drankgebrutk een belangrijke rol spelen bij de afkeuring ervan, niet door mil bestreden. Wel wll ik er een vraag aan toevoegen, name$11 \mathrm{jk}$, of er kondities aan te wljzen z1jn waaronder b1j overeenkomstige mate van nadelige gevolgen de kans op af"keurling van drankgebrulk verschilt.

Het onder andere ult ultspraken van Gadourek en Schtppers te dest11leren model waarmee afkeuring van drankgebruik wordt verklaard kan, sterk vereenvoudigd, als volgt weergegeven worden: 
De plfl die naar konsumptlenfvo wifst, staat voor de verscheldenheld aan faktoren dle geInterpreteerd kunnen worden als konsumptlebevorderend.

Naar mifn mening geeft dit model slechts een beperkt beeld van de ontw1kkeling van drankgebrulk als vanzelfsprekende gewoonte tot een soclaal probleem. In navolging van Philipsen (1976) ben ik van mening dat nadellge gevolgen van drankgebrulk op zlich niet tot afkeuring hoeven te lelden. Worden nadellge gevolgen van drankgebrulk echter door anderen gezlen als corzaak van een nlet of onvolledig nakomen van belangrijk geachte soclale verplichtingen, dan zal er zeker afkeuring optreden. Fen voorbeeld ter lilustratie: blj lemand die twee maal per week dronken thuls kont, echter z1In werk normaal doet, huls en tuin op op orde houdt, en geen flnanclele problemen heeft, acht lk de kans dat het drankgebrutk afgekeurd wordt geringer dan bly lemand die twee maal per week dronken is en geen baan (meer) heeft, financiele problemen heeft en huls en haard verwaarloost.

Vanult deze omschrljving van het punt waarop in een samenleving drankgebrulk als probleem gezien gaat worden, dringt zich nog een andere tekortkoming op van het aan Gadourek en Sch1ppers toegeschreven schema. De kans namel1jk, dat gevolgen van drankgebrulk geassocleerd worden met een nlet of onvolledig nakomen van soclale verplichtlingen, kan naar $1 \mathrm{k}$ aanneem, ook belnvloed worden door de mate waarin de gevolgen van drankgebrulk opvallen. Opvallen in twee betekenissen: Ten eerste kan gesteld worden dat dronkenschap, kater, tremors, black-outs duldel1jker herkenbaar in relatle staan met dronkenschap dan bifvoorbeeld levercirrose, slokdarmkanker, maagzweren. Ten tweede, en dat zal hier een belangrijkere rol spelen, opvallend in de betekenis dat het veel vaker voorkomt dan normaal wordt geacht in de betreffende populatie, on het laatste weer met een voorbeeld te 11lustreren: In kringen waar ledere weekenddag genlddeld zo'n 6 glazen gedronken wordt, kan het vrif gemakkel1jk als onbetekenend incident worden afgedaan als men 1 of 2 keer per maand dronken thuiskomt. Echter in kringen waar bijna alleen bij b1jzondere gelegenheden als verjaardagen, famlliefeestjes e. d. wordt gedronken, zal lemand dle langere t1fd minstens 1 maal per maand dronken is opvallen.

Dit houdt in dat het in een samenleving of subpopulatie normaal geachte drankgebrulk zowel de kans op het vóórkomen van nadelige gevolgen beinvloedt als de kans op afkeuring van drankgebrulk. 
Fen adekwate beschrifving van het proces waarin drankgebruik van een geaksepteerde gewoonte tot een probleem wordt, verelst mifns lnzlens dan ook dat ingegaan wordt op de onderschelden vormen van normaal drankgebrulk en op de faktoren dle samenhangen met versch1llen in "normaal drankgebrulk" Het voorgaande samenvattend, kumen de belangrijkste momenten in het proces warin drankgebruik tot een probleem wordt, als volgt in schema gebracht worden:

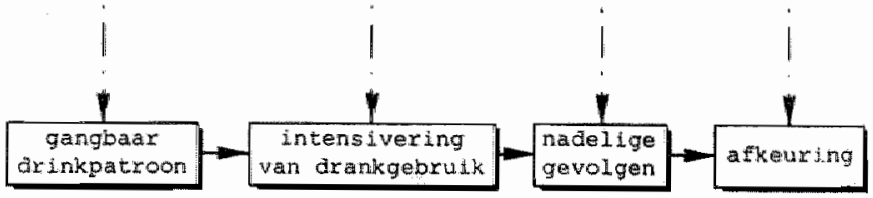

Dit schema is niet alleen uitgebreider andat de varlabele 'gangbaar drinkpatroon' (hlervoor steeds genoemd 'normaal geacht drankgebrulk') er in is opgenomen. Het is vooral uitgebrelder ondat ten aanzien van leder van de punten in het proces die de overgang van drankgebrulk als vanzelfsprekend verschifnsel naar problematies verschifnsel markeren, de vraag gesteld wordt welke faktoren daarop van invloed zifn. Uit dit schema vloeien dan ook de probleemstelilingen voort die hler behandeld zullen worden:

I. Welke gangbare drinkpatronen zijn er in Limburg en Rotterdam te onderschelden?

II. ZIjn er verschillen tussen subpopulaties in de mate waarin één van de te onderschelden drlnkpatronen dominant 1 s?

III. Welke kondities en faktoren -anders dan die welke samenhangen met verschillen in gangbaar drinkpatroonbeinvloeden de kans dat het drankgebrulk geintens1veerd wordt?

IV. Welke andere varlabelen dan konsumptientvo belnvloeden de kans dat drankgebrulk gepaard gaat met schadelljk te achten gevolgen?

V. Welke andere faktoren dan het optreden van schadell Jk te achten gevolgen van drankgebrulk, beInvloeden de kans dat drankgebmulk negatieve reaktles ult de ongeving oproept en/of zorgen bij de drinker zelf? 
In deze serie probleemstellingen zlt impliclet een opeenvolging In de t1jd: men leert te drinken volgens een bepaald drinkpatroon; bepaalde kondities lelden tot dusdanige intenslvering van drankgebrulk dat er nadelige gevolgen optreden, die mogel1 Jkerwl fs afkeuring van het drankgebrutk oproepen. Ideaal zou zifn als deze vragen met gegevens ult een prospektlef opgezet onderzoek beantwoord konden worden. Er wordt hier echter gewerkt met gegevens die op één t1jdstip zijn verzameld. Er kunnen derhalve alleen korrelaties worden gepresenteerd, waarvoor aannemel1jk gemaakt zal moeten worden dat deze $z 1$ jn te interpreteren als corzakel1jke verbanden. Ten aanzlen van de relatles tussen gangbaar drinkpatroon, intensivering van drankgebrutk, gevolgen en afkeuring $11 \mathrm{jkt}$ het me overbodig on uitgebreid te argumenteren waarom het warschl Inlljker is dat bv. het konsumptienivo van invloed 1s op gevolgen in plaats van andersom. Wellswaar moet b1j verslavende stoffen altijd rekening gehouden worden met circula1re kausalltelt (van D1Jk, 1976). Echter in het geval dat bv. onthoudingsverschijnselen lelden tot excesslef drankgebrulk, is de primaire oorzaak toch het konsumptienivo.

Anders is het gesteld met de variabelen die respektlevel1jk gangbaar drinkpatroon, konsumptienivo, gevolgen van drankgebrutk en afkeuring belnvloeden. Voor deze variabelen zal, o. a. door de theoretlese uttgangspunten aan te geven, aannemel1.jk gemaakt moeten worden dat gevonden samenhangen geInterpreteerd mogen worden als corzakel1 jke samenhangen. In de hiemavolgende hoofdstukken II, III en IV zullen dan ook de theoretlese ultgangspunten en in het verlengde daarvan de hypothesen geformuleerd worden.

De opzet van deze studie -probleemstellingen, theorle, hypothesen, toetsing- kan de indruk wekken dat er op emploles en theoreties gebled een traditle bestaat van waarult éénduldig is af te lelden welke faktoren van invloed $\mathrm{zI}$ In op het proces waarin gangbaar drankgebrulk tot een probleem wordt dat afkeuring oproept. Deze indruk is onjuist. Ten aanzien van drle probleemsteli1ngen -die betreffende gangbaar drinkpatroon, nadelige gevolgen en afkeuring- is nauwelijks of geen gedragswetenschappel1Jke 11teratuur voorhanden. Dit is geen reden geweest on af te zien van theorlevorming en het aflelden van hypothesen. Het is wél de aanlelding om in de analyse, voorzover relevant en mogelijk, verder te gaan dan de toetsing van de hypothesen op zich verelst. Dit geldt met 
name de hypothesen over de invloed van strukturering van het dagel1jks bestaan op respektlevel1 jk konsumpt1enlvo, nadel1ge gevolgen en afkeuring van drankgebrulk. B1f deze verdergaande analyses heeft deze studie een meer explorerend dan toetsend karakter. 


\section{Gangbare drinkpatronen}

In dit hoofdstuk komen de eerste twee probleemstellingen aan de orde. Dit zal gebeuren door de gedragskategorle waarin alkoholgebrulk thulshoort aan te geven en te beredeneren waarom verwacht wordt dat de verscheidenheld aan ind1vidueel drinkgedrag zich laat beschrifven in enkele gangbare drinkpatronen (eerste probleemstelling). Tevens zal in dit hoofdstuk een antwoord gezocht worden op de vraag welke groeperingen mogellfkerwifs verschillen in drinkpatroon (tweede probleenstelling).

B1 f de behandeling van de eerste twee probleemstellingen zal de theorle beschreven worden die in deze studie de selektle van faktoren bepaalt die van invloed geacht worden op verschillen in gangbaar drinkpatroon. Deze theorle is ook de leidraad in de volgende hoofdstukken, waarin de faktoren die van invloed kumnen zifn op achtereenvolgens intensivering van drankgebrulk, nadelige gevolgen van drankgebrulk en zorgen over of afkeuring van drankgebrulk worden besproken.

\section{1. Drankgebrulk als gewoonte, drinkpatronen}

De gedragskategorle waartoe Gadourek drankgebrulk (1963) rekent -die van de gewoonten- is nog steeds geldig. Hif onschrifft gewoonten als: "een elementa1re struktuur van het kollektleve gedrag, die de enkeling van de samenleving op een haast onbewuste wljze overneemt, in zlifn persoonlifkheldsstruktuur opneemt en in niet al te lange intervalien in z1.jn handelingen en verrichtingen manlfesteert' (Gadourek, 1963, p. 37).

Daarmee zijn gewoonten onderschelden van andere gedragskategorieèn zoals

- Individuele eigenaardigheden, $\infty \mathrm{k}$ al worden die dagelljks herhaald

- incidentele en/or butten het alledaagse leven vallende gedragswijzen, ook al zijn ze kollektlef (folklore, traditles)

- t1jdelljke (vaak modieuze) gedragswijzen ook al zijn ze kollektlef en maken ze voor een bepaalde perlode deel ult van het dagelljks leven (rages) 
- rolgedrag, dat, $\infty \mathrm{k}$ al is het regelmatig en maatschappe$11 \mathrm{jk}$ bepaald, nlet als en elementalre struktuur van het kollektleve gedrag bechouwd mag worden volgens Gadourek

Het in de eerste twee probleemstellingen gebrulkte begrip "gangbaar drinkpatroon" kan worden opgevat als een specif1katie van het begrip gewoonte.

Een formele anschrijving van gangbaar drinkpatroon is: een vorm van drankgebrulk, blj grote delen van de drinkende bevolking aan te treffen, die gekenmerkt wordt door een spec1fleke samenhang tussen onderschelden aspekten van het drinkgedrag.

Relevante aspekten van drinkgedrag zijn onder andere de konsumptle per keer, de frekwentle waarmee wordt gedronken, de situaties waar meestal wordt gedronken (bv. café of thuis), de soort drank die wordt gedronken.

Het begrip gangbaar drinkpatroon, in de hier aangehouden omschrifving verschilt overigens essentiëel van door andere onderzoekers gebrulkte typologleën van drinkers (Strauss, Bacon, 1953; Cahalan, e.a. 1969; Robinson, 1976; Sijlbing, 1978; Schtppers, 1981; Fitzgerald en Mulford, 1981; Garretsen, 1983) Deze onderzoekers hanteren een zogeheten 'quant1ty-frequency-index', warmee drinkers in felte grotendeels geordend worden naar konsumptienivo. Grotendeels, omdat zoals Skog (1981) aantoont drinkers met een zelfde totale konsumptle aan alkohol toch in verschlliende kategorleën van de door deze onderzoekers gehanteerde indexen geplaatst kumnen worden.

Het essentlele onderscheld tussen de door deze onderzoekers gehanteerde typologleën van drınkers en het begrlp gangbaar drinkpatroon is dat bif gangbare drinkpatronen verschilien In konsumptienivo niet bij voorbaat tot de definiërende kenmerken gerekend worden. Vanzelfsprekend kunnen deze verschlllen er zIJn maar, om een voorbeeld te geven, eenzelfde konsumptientvo van 20 glazen per week kan op twee geheel verschillende drinkpatronen wijzen: 1eder dag van de week bljna drle glazen, of twee weekenddagen gemiddeld 10 glazen en op doordeweekse dagen niets.

Het begrlp gangbaar drinkpatroon veronderstelt dat de verschillen tussen individuen wat betreft drinkgedrag niet zo groot zijn dat een meer samenvattende beschrijving in één of 
meer gangbare dr1nkpatronen onmogel1jk wordt. Voor éen aspekt van het drankgebrulk, namel1jk konsumptienivo, kan op grond van onderzoeksgegevens bevest1gd worden dat er een vrlj grote unfformitelt is. Het bl1jkt namelijk dat in verschillende samenlevingen de verdeling van drinkers naar konsumptienivo verloopt volgens een kurve met slechts één plek (zogeheten unimodale kurve) en dat deze kurve stell onhoog gaat naar de top on vervolgens ook vrly snel te dalen (Ledermarn, 1956; de Llnt, Schmidt, 1968; Brun, e. a. 1975; Schmldt 1977). De snelle st1Jglng en daling betekent dat twee derde van de bevolking evenveel of slechts weinig meer of minder arlinkt dan het gemlddelde konsumptienivo in de betreffende bevolking. (Skog, 1983)

ook al betreft het slechts éen aspekt van het drinkgebrulk, toch is het opmerkel1 $1 k$ dat b1 een gedragselenent als drankgebrulk, waar het individu een zo grote vrijheid heeft or bemoelenis van anderen af te wljzen, door een zo grote unfformitelt wordt gekermerkt.

De verklartng voor deze uniformitelt in konsumptienivo, een unlformltelt die naar $1 \mathrm{k}$ verwacht ook voor andere aspekten van drankgebruik zal gelden, moet gezocht worden in de wljze waarop de enkeling 'op haast onbewuste wljze' de gewoonte van drankgebmulk overneemt.

Ledermann (1956) typeert dit proces als 'besmetting'. Kort gezegd stelt hif dat als individuen zlch werkelljk vrlf zouden gedragen, de verdeling van drinkers over opeenvolgende konsumptlentvo's volgens een Gauss nomaalverdellng zou verlopen. Aangezien er sprake is van een stellere verdeling met een lange ultloper naar rechts -aangenomen wordt dat een log-nomaal-kurve de verdel1ng van konsumptle adekwaat zou beschr1 Jven (Ledermann, 1956, Bmun e.e., 1975, Skog, 1982, 1983) -moeten er soclale krachten aan het werk z1jn, voornamel1jk in de sfeer van onbedoelde maar toch sterke wederz1Jdse beInvloeding, die tot deze unlfomitelt in konsumptlenivo lelden.

Skog (1980) laat zien dat het proces in temen van soclale Interactle beschreven kan worden. Sterk vereenvoud1gd, Implleeert de redenering van skog dat mensen zelden alleen drinken en dat in groepen de hoeveelheld die een Individu drlnkt sterk beInvloed wordt door de hoeveelheld die anderen drinken. Deze wederzl jase beinvloeding verloopt volgens bepaalde regels. Rondjes geven 1 s een heel konkreet voorbeeld van een gedragsregel die tot een grote unlformitelt in kon- 
sumptlenfvo leldt. Twee meer algemene regels die Bruin (1959) op grond van een observatiestudle formuleert, lelden ook tot unfformitelt in konsumptientvo:

- "A member of the group is forbldden to drink less than the other members";

- "A member of the group is permitted to arink more than the other members"

In groepsexperimenten is 0. a. aangetoond dat de hoeveelheden die proefpersonen drinken sterk afhankel1jk zIJn van de hoeveelheden die anderen (waaronder vooraf" geinstmueerde medewerkers aan het experiment) drinken (Caud111 en Marlatt, 1975; Reld, 1978, De Rlcco en Garlington 1977). Echter ook als er geen vooraf gelnstrueende deelnemers bIj een drinksituatle aanwezlg z1jn, bl1jken deelnemers van groepen slechts welnig te verschillen in konsumptlentvo (Bruun, 1959, Cutler, Stom, 1975).

Het hlervoor aangedulde soclale proces geeft een naar miln menling goede beschrijving hoe in drinksituaties een zekere uniformitelt tussen deelnemers tot stand kont wat betreft te drinken hoeveelheden. De vraag 1 s echter of de deelname aan de grote verscheidenheld aan drinksituaties (b.v. thuls bif het eten, b1j vrlenden, café, receptle, feestjes etc.) door een even grote uniformitelt wordt gekenmerkt. Skog (1980) 11jkt impllclet de mogelljkheld open te houden dat er ten aanzlen van konsumptientvo - en dat is een varlabele die samengesteld is uit de frekwentie van drankgebrulk (1.c. deelname aan drInksituaties) en de hoeveelheld die per keer wordt gedronken- in een samenleving stablele verschillen bestaan tussen groeperingen.

Hij stelt namelifk dat in het netwerk een sterke wederzljdse beInvloeding 1s, zowel wat betreft de situatles waarin het nomaal is te arinken als wat betreft de hoeveelheden die in deze situatle worden gedronken. In een samenleving kumnen netwerken echter meer of minder onafhankel1 Jk van elkaar $\mathrm{z} 1 \mathrm{Jn}$, waardoor er stablele verschillen tussen soclale groeperlingen kumnen ontstaan in $0 . a$. de hoeveelheld die per keer wordt gedronken en/of" de sltuatles waarin wordt gedronken. Voorzover het bestaan van netwerken ale verschillen in drinkpatroon af"geleld kan worden uit stablele verschillen in konsumptlentvo, kan voor Nederland verwezen worden naar twee artikelen (Phllipsen e.a., 1983; van Reek e.a. 1983) warlin aangetoond wordt, dat tussen 1958 en 1981 er stablele ver- 
schillen zIjn in konsumptienfvo naar geslacht, oplelding, en godsdienst.

De eerste hypothese is derhalve:

de verscheidenheid aan drinkgedrag van individuen kan

samenvattend beschreven worden in enkele gangbare drinkpatronen.

Echter nlet aangegeven kan worden hoe deze gangbare drinkpatronen er ult zlen. Voor de wljze waarop verschillende aspekten van drinkgedrag als waar men drinkt, wanneer, hoeveel, met wle, zich samenvoegen tot een gangbaar drinkpatroon $\mathrm{zl} J \mathrm{n}$, naar $1 \mathrm{k}$ meen, geen algemene regels te geven. Hier wordt derhalve verondersteld dat de wijze waarop de enkeling op "haast onbewuste wljze" drankgebrulk als soclale gewoonte overneent, geschledt via het overnemen van één van de gangbare drinkpatronen.

Drinkpatronen bevatten, meer impliclet dan expliclet, aanwijzingen hoe drankgebmutk in het geheel aan gedragsmogelijkheden een betekenlsvolle plaats te geven. Deze aanwifzIngen kumnen nomatlef genoemd worden ondat in een samenleving drankgebrulk slechts dan als 'soclale gewoonte' ervaren kan worden voorzover het drinkgedrag is te plaatsen in de kontekst van één van de gangbare drinkpatronen. Een voorbeeld: het Inrullen van het slaapmuts je voor een opkikkertje in de vorm van een glas jenever bij de ochtendkoffle zal niet of zelden als 'sociale gewoonte' worden gezlen.

Is er hier nu sprake van een tegenstelling met eerdere ultspraken dat drankgebrulk niet of nauwel1 Jks genomeerd 1s? Naar mifn mening niet. Eerder had $1 \mathrm{k}$ het over normen die het drinkgedrag dusdanig beperken dat de kans op nadelige gevolgen geminimaliseerd wordt. Hier heb $1 \mathrm{k}$ het over aanwi fzingen voor betekenlsvol gebrulk van alkohollese drank. Aangenomen mas worden dat in het leven van alledag er een minder sterke preokkupatle is met het felt dat drankgebrulk tot nadelige gevolgen kan leiden dan bv. b1 f onderzoekers naar drankgebrulk. De in drinkpatronen impliclet aanwezige aanwljzingen voor drankgebrulk geven de sociale kontekst van drankgebruik, en daarbinnen hebben Individuen het recht bemoelents van anderen af te wljzen. Het zijn geen aanwijzingen hoe men een verstandige, matige en tevreden drinker kan zijn. In Limburg bv, antwoordt 49\% van de respondenten dat een man zoveel mag drinken op een feestje als hif zelf wil en $44 \%$ van de respondenten vindt hetzelfde ten aanzien van drankgebrulk door vrouwen op een feestje. Tegenspraak zle $1 \mathrm{k}$ 
hier derhalve niet. Wel een spanningsveld, omdat de grens tussen het recht van het individu de bemoelenis van anderen af wljzen en het recht van anderen nadelige gevolgen van drankgebruik te veroordelen nlet vast ligt. Dit spanningsveld is echter onophefbaar, en de konstatering ervan is in felte een andere manier om te zeggen dat drankgebrulk, soclologies gezlen, tot de riskante gewoonten gerekend moet worden.

De tweede probleemstelling-groeperingen die verschillen in drinkpatroon- betreft meer toegespitst de vraag of er behalve de brede verwachting de enkeling zifn drankgebrutk volgens één van de gangbare drinkpatronen inricht, nog verdergaande verwachtingen zifn aangaande welk van de drinkpatronen het meest geschikt is.

De redenering van Skog volgend zou de tweede probleemstelling als volgt geformuleerd kunnen worden: ziln de netwerken die gekenmerkt worden door een relatief uniform drinkpatroon samengesteld uit individuen met overeenkomstige soclale kenmerken?

Of, vanuit het perspektief van het individu gesteld: volgt de enkeling wat betreft drinkpatroon die anderen na, met wle hif gemeenschappel1jke sociale kermerken heeft.

Men kan in antwoord op de vraag redeneneren dat van het individu verwacht wordt dat hif één van deze drinkpatronen volgt. Verdergaande verwachtingen aangaande welke van de gangbare drinkpatronen wensel1jk is, zijn echter ntet aanwezlg.

Deze redenering wordt hier niet gevolgd. Hier wordt er vanult gegaan dat op twee manieren verdergaande verwachtingen kunnen (echter niet moeten) bestaan aangaande het specifleke drinkpatroon dat voor lemand 'normaal' wordt geacht:

- binnen en/of bulten een soclale groepering kumnen opvattIngen bestaan over drInkpatronen die beslist niet passend worden geacht voor leden van de betreffende soclale groeperling.

B1jvoorbeeld, gesteld dat cafébezoek in het weekend één van de gangbare drinkpatronen 1 , dan kunnen vele mannen en vrouwen van mening zijn dat deze vorm van drankgebrulk niet passend ('fatsoenll $1 \mathrm{Jk}$ ') is voor oudere gehuwde vrouwen.

Fr kunnen in een soclale groepering ook meer of minder sterk gedeelde opvattingen bestaan over het meest passende drinkpatroon. 
Vanzelfsprekend kan de opvatting dat een hepaald drinkpatroon niet "nomaal" is heel goed samengaan met de opvatting dat een ander drinkpatroon passend wordt gevonden.

Het algemene antwoord op de vraag welke subpopulaties zullen verschillen in de mate waarin een bepaald gangbaar drinkpatroon voorkomt (probleenstelling II), Is dat dit statusgroeperingen zullen ziln.

Daarmee $1 \mathrm{~s}$ over1gens niet gezegd dat tussen alle statusgroeperlngen verschilien in gangbaar drinkpatroon zijn vast te stellen.

Het begrip statuskenmerken wordt hier gebmulkt in de betekenls van aan het Individu te onderschelden kenmerken waarop het weinig of geen invloed heeft en die op entgerlel wijze soclaal gewaardeerd worden.

Voorbeelden van statuskenmerken zlJn: geslacht, leeft1 Jd, godsdlenst, soclale klasse. Een aspekt van statuskemmerken dat in de soclale wetenschappen vaak benadrukt worden is dat enerz1Jds de enkeling welnig of geen Invloed heeft op deze kermerken, anderzljds de sociale waarderling in een rangordening tot ultdmukking komt waardoor statuskermerken $z 1 \mathrm{fn}$ mogel1jkheden en kansen in het soclale leven belnvloeden. Dok hier zal aan dit aspekt nlet voorbl Jgegaan worden. Dehter In eerste Instantle zullen we ons op een ander aspekt van statuskemmerken konsentreren.

Variult het IndIvidu bezlen kan aan statuskenmerken een pos1tleve funktle worden toegekend. Omdat deze kermerken aan het individu zelf zljn gebonden, in afwljking bifvoorbeeld van een positle in een ocganlsatie, impliceert een statuskemnerk ook een meer kontlnue en met anderen gedeelde orlëntatie hoe zlch te gedragen in wlsselende soclale sltuaties. Met name In situaties waar geen of slechts in geringe mate expliclete soclale verpllchtingen het handelen structureren -en daartoe behoort het overgrote deel van de drinks1tuaties- zal deze met anderen gedeelde orlëntatle zifn invioed doen gelden op de selektle van gedragingen. Voor een verdere ultwerking van deze gedachtengang, moet $1 \mathrm{k}$ gebrulk maken van een begrip waarvan Gadourek stelt dat het ongeschikt is om drankgebrulk te verklaren: het rolbegrlp. In de volgende paragraaf zullen de voomaamste begrippen van een rol theorle ulteengezet worden. Aan de hand van deze roltheople zullen de onafhankel1 Jke varlabelen die van invloed worden geacht op gangbaar delnkpatroon, konsumptlentvo, nadellge gevolgen en afkeuring van drankgebrutk, worden geselekteerd. 
II. 2. Roltheorie: een nadere plaatsbepaling van drankgebrulk

Het argument van Gadourek on drankgebrulk niet tot het rolgedrag te rekenen, is dat drinkgedrag niet begrepen kan worden vanult de maatschappel1jke positie en daarmee verbonden rol -bv. leraar, polltleagent, hulsvrouw- die lemand inneemt. Wat betreft bovengenoemde voorbeelden kan daarmee Ingestemd worden, echter in navolging van Gerhardt (1971) kan een onderscheld gemaakt worden tussen statusrollen, positierollen (daaronder vallen bovengenoemde voorbeelden) en situatierollen.

Philipsen (1976) heeft laten zien dat de beschrijving van drankgebruik vanult deze roltheorie tot soclologles relevante inzlchten leidt. Dok hier zal de roltheorie, met name die van Gerhardt, gebrulkt worden om tot een theoretlese plaatsbepaling te komen van drankgebmulk. Allereerst zullen de begrippen status-, positie- en situatierol nader omschreven worden. Daarna zal beschreven worden welke plaats drankgebrulk in dit schema heeft.

II.2.1. Statusrollen

Statusrollen worden gevormd door de verwachtingen die anderen koesteren Jegens lemand op grond van de statuskermerken die $h i j / z 1 j$ heeft. Statuskenmerken $z 1$ jn al eerder anschreven als aan het individu te onderscheiden kenmerken waarop het weinfg of geen invloed heeft en die op enlgerlel wijze soclaal gewaardeerd worden. In de verwachtingen die tot een statusrol behoren kan een globaal onderscheld gemaakt worden tussen gedragsverwachtingen die in een statusgroep leven en de gedragsverwachting die leden van een andere statusgroepering hebben. In eerste instantle beperk $1 \mathrm{k}$ me tot de statusrolverwachtingen die relevant zifn binnen de statusgroepering waartoe lemand behoort.

Omdat statuskenmerken aan het individu zelf gebonden $\mathrm{zl} \mathrm{fn}$, kunnen statusrollen in principe in alle sociale situaties tot gelding gebracht worden, ook in situaties waar de interaktle voor een groter of kleiner deel tot positie- of sltuatierollen te herleiden 1s. In bifvoorbeeld een werksituatie, zal de interaktie grotendeels voortvloelen uit de 
positierollen van de diverse deelnemers. Toch kumnen in de wIjze waarop men met kollega's of superleuren omgaat elementen van de statusrol temg te vinden zijn.

In statusrollen ligt het aksent niet zozeer op nauwkeurig onschreven gedragsverwachtIngen, maar meer op in de betreffende statusgroepering relevant geachte waarden. Waarden die In een verscheidenheld aan situaties en gedragingen tot ultarukking gebracht kunnen worden. Voor het Individu is de komblnatie van met anderen gedeelde relevante waarden en de relatlef grote individuele vritheld daar gedragsmat1g vorm aan te geven een belangrljk aspekt van statusrollen. Daardoor bleden statusrollen potentiëel de mogelifkheid een soclale 1dentite1t te ontwikkelen, waar In verbondenhe1d met anderen en persoonl1jke gedragskeuzes gekomblneerd worden. Ondat bif de statusrol sprake is van een relatief grote vritheld daaraan gedragsmatig vorm te geven, is minder nauwkeurlg aan te geven wanneer bepaald gedrag sankties oproept. Toch zijn de vrlJheden begrensd. Er zljn ten eerste de waarden waarover bimen de statusgroepering grote konsensus bestaat. Is gedrag over langere t1 jd niet in overeensteming met wat binnen de statusgroepering als statusrol wordt opgevat, dan is de basis voor een vanzelfsprekend elkaar aksepteren en angaan met elkaar weggevallen. Ten tweede kumnen andere statusgroeperingen dan waartoe men behoort, statusrolverwachtingen koesteren waaraan men zich moe $111 \mathrm{jk}$ onttrekken kan.

Ondat statusrollen voor het individu middel zifn on zifn soclale 1dentiteit tot ultdrukking te brengen, kan het oordeel dat deze nlet adekwaat ultgevoerd worden, verstrekkende konsekwentles hebben. Onder meer kan men bekend komen te staan als 'afwljkend" waardoor men in meer of mindere mate gelsoraakt.

II. 2.2. Posttierollen

Positierollen bestaan ult normatleve verwachtingen gekoesterd op grond van de positie die lemand inneemt in een organlsatle of Institutie. Kenmerk van posities -en positierollen- is dat deze los gezlen kumnen worden van de aktuele bekleder van de positie. Duidel1jk is dat b1j de positie van 
direkteur, bankemployee, leraar, pol1tleagent, voorzltter van een verenlging. Echter ook binnen het familleleven zifn posities en daaraan verbonden rolverwachtingen te onderschelden die los staan van de aktuele bekleders: vader, moeder, kinderen, coms, tantes, e.d.

Positierollen zIIn, sterker dan blj statusrollen het geval is, te omschrljven in termen van Inhoudelijke gedragsverwachtingen: van een diensthoofd bijvoorbeeld wordt verwacht dat hif taken goed verdeelt, de ultwoering bewaakt. Ook het t1jdstip van ultvoering en de angeving waar positierolien worden uitgevoerd $\mathrm{zIJn}$, vergeleken met statusrollen, beter aan te geven. Doordat positierollen nauwkeuriger zifn onschreven, maar ook omdat men voor het elgen funktioneren afhankelijk is van een adekwate vervulling door anderen van hun positierollen, zlJn aan het niet nakomen van positilerolverplichtingen veel direkter sanktles verbonden.

Positierollen hebben vanult het individu bezlen de funktie van strukturering van het dagel1jks leven. Positierollen bestaan grotendeels uit specifleke verplichtingen, die met zekere regelmaat nagekomen moeten worden. Daamee 1 s een Broter of kleiner deel van de tijd met betekenisvolle akt1vitelten gevuld.

\section{2. 3. Situatierolien}

Situatlerollen worden gevormd door de nomatleve verwachtingen van deelnemers aan situatles waarin doeleinden worden nagestreefd die in de betreffende situatle worden verwezen11.jkt. Verkeer, feestjes, sportwedstrijden bezoeken, t.v. $\mathrm{kl}$ jken, cafébezoek zljn voorbeelden hlervan en het geneenschappe 11jke kemmerk is dat het op z1chzelf" staande sltuaties z1jn, van een beperkte t1jdsduur, waarin de situatierol het deelnemers mogel1 $\mathrm{jk}$ maakt $\mathrm{zlch}$ adekwaat te gedragen. S1tuatierollen kunnen worden getypeerd naar de mate waarin deze speciflek of diffuus z1.jn (Gerhardt, 1971). Fen spec1fleke sltuatlerol als b1jvoorbeeld verkeersdeelnemer, impliceert dat de ultvoering van de rol aan een specifleke ongeving is gebonden. Kenmerk van deze rollen is dat de gedragsregels veelal nauw omschreven $z 1 j n$ en er weinis of geen mogel1.Jkheden zlJn on elementen van de statusrol in deze situatles (ook) tot uitdrukking te brengen. 
Een diffuse sltuatierol kan in een verscheldenheld van situaties tot gelding gebracht worden. Voorbeelden hlervan z1jn: deelnemer aan een feestje, gastvrouw, cafébezoeker. De gedragsverwachtingen $z 1 . \mathrm{Jn}$ minder scherp omschreven en in deze s1tuatlerol is het mogelijk on elementen van de statusrol tot ultarukking te brengen.

II. 3. Gangbare drinkpatronen en roltheorie

II. 3. 1. Statusrol en drinkpatroon

Gebrulk van alkohollese drank vormt geen onderdeel van de positierol. Integendeel, drankgebrulk tijdens de uitvoering van positierollen wordt in de regel afgekeurd. In alledaagse termen: drinken t1jdens het werk mag niet, alhoewel er ook op deze regel uttzonderingen zifn aan te wifzen, bifvoorbeeld kasteleins, d1sc-Jockeys.

Evenzeer geldt dat drankgebrutk voordat het werk gedaan is -1.c. voordat verplichtingen voorvloelend uit posities die men inneemt vervuld zijn- in de regel afgekeurd wordt. Vanult de roltheorle kan verslaving beschreven worden als verdringing van positierollen door situatierollen die een direkte behoefte bevredigen (Philipsen 1976). Zo bezien valt een hulsvrouw die door bingo-spelen of dokterromannetjes lezen positierolverplichtingen als eten koken, de verzonging van kinderen verwaarloost, onder de verslaafden. De hulsvrouw die zonder zichtbare noodzaak dag in dag ult bli.jft poetsen mag echter, soclologies gezien, niet tot de verslaafden worden gerekend.

Drankgebruik hoort thuis in situatierollen. De meeste situaties waarin een groter of kleiner deel van de bevolking drinkt -feestjes, bif het eten, 's avonds thuis, in het café, blj kennlssen op bezoek, receptles, etc.- hebben gemeen dat er geen positierolverplichtingen gelden die het gedras in de betreffende situatie bepalen. Het is bij het ontbreken van deze verplichtingen dat drankgebrulk in principe tot de mogelljkheden gaat horen. Simpeler gezegd: drankgebruik hoort thuis in de vrije tijd. 
De selektie van situaties wartn men gewoon is te drinken, is echter een element van de statusrol.

Van de statusrol is gezegd dat het de enkeling een meer kontinue orlëntatie biedt in de wisselende soclale situaties waarin hif zich beweegt. Deze in de statusrol vervatte orlëntatie komt ook tot uitdrukking in aanwl jzingen voor het individu hoe drankgebrulk als een betekenisvol element in het geheel van zifn gedragsmogelljkheden is op te nemen. Deze aanwljzingen mogen rolverwachtingen genoemd worden, ondat het opvolgen van deze aanwljzingen mede bepaalt of anderen het drankgebruik van de enkeling als een soclale gewoonte kumen zlen. Een soclale gewoonte in twee opzichten:

- men deelt met anderen de betekenissen waarmee drankgebrutk is amgeven. Om een paar voorbeelden te noemen: men deelt de mening dat drankgebrulk in het bijzonder (of ultsluitend) geschikt is an bifzondere gebeurtenissen luister bif te zetten; of men deelt de mening dat een aperitief de overgang van werk naar huis vergemakkel1jkt; of men deelt de mening dat in het weekend in het café men zich pas echt bevrifdt van alledaagse beslomeringen.

- de gedeelde opvattingen over situaties waarin men drankgebrulk normaal acht, impliceren gedeelde opvattingen over de beperkte plaats die drankgebrulk in het geheel aan gedragsmogelijkheden heeft. Anders gezegd: men deelt opvattingen in welke situatles drankgebrulk niet vanzelfsprekend is, welke motieven an te drinken niet de juiste z1jn.

Zich onttrekken aan deze in de statusrol gelegen aanwfjzingen voor drankgebmulk betekent dat men de verdenking op zich laadt niet tot de 'soclale' drinkers te horen. Anders gezegd als men bif de 'verkeerde' gelegenheden en met 'verkeerde' motieven drinkt, loopt men grote kans als potentieel alkoho11st beschouwd te worden, zelfs al is het betreffende drankgebrulk nlet schadelijk.

Met het voorgaande is aangegeven waarom ik het 't meest waarschilnl1.jk acht dat statusgroeperingen zullen verschillen in gangbaar drinkpatroon. De roltheorle leent zich niet voor een verklaring hoe in een statusgroepering gedeelde opvattingen ontstaan over de wijze warop drankgebrulk als een betekenisvol element in het leefpatroon kan worden opgenomen. Noch geeft deze theorle ultslultsel welke statusgroeperingen het meest waarschijnlijk zullen verschillen in gangbaar drinkpatroon. De vraag naar het ontstaan van ge- 
deelde opvattingen over drankgebrulk valt bulten het bestek van deze studle. De tweede vraag, welke statusgroeperingen zullen verschllien in gangbaar drinkpatroon, behoort wel in deze studie thuls en zal in de volgende paragraaf worden behandeld.

II. 3.2. Statusgroeper1ngen die versch1llen in gangbaar drinkpatroon

Afgaande op blmen- en bultenlands onderzoek (Gadourek, 1963; Siflbing, 1978; Garretsen, 1982; Kntbbe, 1982; Cartwrlght en Shaw 1978; Cahalan e.a. 1969; F1tzgerald e.a., 1979; Hauge, 1978, Phillpsen e.a. 1983) wordt voor de volgenden statuskenmerken het vaakst een verband gemeld met verschillende aspekten van drinkgedrag: geslacht, leeft1 fd, soclale klasse, godsdlenst en etniese groepering. U1tgezonderd het voor Nederland in deze kontekst minder relevante statuskenmerk etnlese groepering, kunnen verschilien in gangbaar drinkpatroon verwacht worden tussen statusgroeperlingen gedefintëerd door één of meer van bovengenoende kenmerken.

Moellijker wordt het on aan te geven welke statusgroeperingen nu konkreet zullen verschillen in gangbaar drinkpatroon.

Behalve het felt dat de drinkpatronen zelf nog niet beschreven z1.jn, spelen nog drie andere problemen een rol:

- Ntet bekend is of er in de onderzoekspopulaties als geheel, of grote delen ervan onverschllligheld heerst aangaande de vraag welke van de gangbare drinkpatronen $\mathrm{mu}$ de meest passende is.

- Er is welnig bekend over de strukturele en kulturele voorwaarden waaronder drankgebmulk een dermate gewaardeerd gedragselement is, dat statusgroeperingen geneigd zijn een speciflek drinkpatroon als "stijlelement" aan hun statusrol toe te voegen.

Ik zou bv. niet met enlge precls le kunnen aangeven onder welke voorwaarden een statusgroepering geneigd is bv. cafébezoek in het weekend of drankgebruik bij het avondeten te benadmukken als "st1.jlelement" in de statusrol. Er is welnig onderzoek gedaan naar de voomwarden waronder een negatief oordeel van anderen over een in een 
bepaalde statusmoepering, gewaardeerd drinkpatroon,

leldt tot verandering van het betreffende arinkpatroon.

Over alt probleem is echter lets meer te zeggen. Besllssend moet hier worden geacht dat de afkeuring in de dagel1jkse leefsltuatie merkbaar is.

Een tweetal voorbeelden van gevallen waar wel negatleve oordelen over het huldige drinkpatroon bestaan zonder dat verwacht kan worden dat dit daadwerkel1jk Invloed heeft op het drinkpatroon zullen worden gegeven.

Door grote delen van de Noorse bevolking schljnt dagelijks drankgebmulk als extravagant, zoal niet excesslef, beschouwd te worden (Hauge, 1978). Toch vindt men dit drankgebrulk vaak in de hogere klasse in Noorwegen en de afkeuring van voornamelljk mensen uit de midden- en lagere klasse weerhoudt ze niet on het als een gewaardeerd element van hun leefstijl te blijven zien.

Het tweede voorbeeld betreft het drinkpatroon dat gangbaar is b1 J Jongeren in Limburg. Het drinkpatroon van Jonge mamen in Limburg roept bif grote delen van de Limburgse bevolking verontrusting op (Knibbe, 1982), omdat het zo vaak leldt tot nadelige gevolgen. Gezlen het felt dat een mulme meerderheld van de jongere mannen ult lagere en middenklasse en een grote minderheid van de jongere mannen ult de hogere klasse dit drinkpatroon volgen, kan echter niet gesteld worden, dat deze verontrusting veel invloed heeft op de mate warin het betreffende drinkpatroon positief gewaardeerd wordt door jongeren.

U1t genoemde voorbeelden kan duidel1jk worden dat als de afkeuring nlet struktureel in de leefsituatle van de betreffende statusgroepering is verankerd, deze afkeuring niet effektlef is. B1j de hogere klasse in Noorwegen onttrekt de gezinssituatie zich aan observatie en daarmee aan direktie afkeuring van lagere en middenklasse. Blf de fongeren mist de afkeuring effektivitelt andat deze veelal in een overgangssituatle zitten waar het ouder $11 \mathrm{Jk}$ gezag aan geldingskracht verllest en het drankgebruik zlch voor een groot deel bultenshuls, in café, disco e. d. afspeelt.

B1j de genoemde statuskenmerken (geslacht, leeft1jd, soclale klasse en godsdlenst) is er slechts één waarvan verwacht kan worden dat, zo er negatieve verwachtingen omtrent een drinkpatroon bestaan, deze ook daadwerkel1jk van Invloed zullen zijn: vrouw -zijn. Voor vrouwen zou het moell1jker kumnen zIJn zich aan negatieve verwachtingen van mannen omtrent 
drinkpatroon te onttrekken andat, met name bij gehuwde vrouwen, de leefsituatile zich sterker dan bif mannen bepaalt tot de gezlinssituatle. Mogel1Jk dat in deze bil vrouwen nog verschillen ziJn naar soclale klasse. Zou het drankgebrulk dezelfde trend volgen als het roken van slgaretten, dan is te verwachten dat vrouwen uit de hogere soclale klasse zich sterker onttrekken aan negatieve verwachtingen ontrent voor vrouwen nomaal geacht drankgebruik (van Reek,1983). Konkreet zou dit betekenen, dat in de hogere klasse het versch1l tussen marnen en vrouwen in gangbaar drinkpatroon gerlnger is dan in de lagere en middenklasse.

Vatten we voorgaande in een hypothese samen dan luldt deze:

er zijn verschilien in drinkpatroon tussen statusgroe.

peringen gedefinieerd door een of meer van de status-

kenmerken geslacht, leeftiti, sociale klasse en

godsdienst.

Afgezlen wordt van speciflkatle van deze hypothese wat betreft versch1llen tussen mannen en vrouwen naar gelang soclale klasse. Bif de resultaten zal daar wel op temg worden gekomen.

Samenvatting

Drankgebrutk kan in navolging van Gadourek tot de gedragskategorle der 'gewoonten' worden gerekend. Het begrip gangbaar drinkpatroon, te onschrljven als een vorm van drankgebrulk, blj grote delen van de bevolking aan te treffen, die wordt gekenmerkt door en spec1fleke samenhang tussen verschillende aspekten van drinkgedrag, is een verdere toespltsing van het begrip gewoonte op drankgebrulk.

Het begrlp gangbaar drinkpatroon veronderstelt dat ondanks het ontbreken van gedeelde gedragsnomen aangaande drankgebrulk, de Individuele verscheidenheld aan drinkgedrag nlet dusdanig groot is dat een meer samenvattende beschrijving in enkele drinkpatronen onmogel1jk 1s.

AanwlJzlngen dat er sprake is van een zekere unfformiteit in drınkgedras kan ten aanzlen van één aspekt van drınkpatro- 
nen, konsumptientvo, gevonden worden in de emplriese verdeling van drlinkers naar konsumptienivo.

In verschillende samenlevingen en op diverse tijdstippen blifkt de unimodale kurve die deze verdeling beschrijft vrly stell te verlopen. Hierult is onder andere af te leiden dat een grote meerderheld van de drinkers evenveel of slechts welnig meer of minder drinken dan de geniddelde konsumptie per hoofd van de bevolking in de betreffende populatie. U1t experimenteel en observationeel onderzoek blijkt dat in konkrete drinksituaties de participanten slechts weinig verschillen in de hoeveelheld alkoholhoudende drank die wordt gedronken.

Met betrekking tot drinkpatronen moet echter de vraas gesteld worden of ten aanzien van andere aspekten van drinkgedrag, waaronder de selektie van situaties warin men gewoon is te te drinken (1.c. de frekwentie van drankgebruik), ook unlfomiteit is te konstateren.

Skog doet de suggestle dat in een samenleving verschlllende netwerken kunnen bestaan die zich onderschelden wat betreft de situaties waarin men gewoon is te drinken en/of de hoeveelheden, soort drank e.d. die men gewoon is te drinken. In deze studie wordt als hypothese aangehouden:

de verseheidenheid aan drinkgedrag van individuen kan samenvattend beschreven worden in enkele gangbare Arinpatronen.

De tweede probleemstelling van dit hoofdstuk -groeperingen die verschillen in gangbaar drinkpatroon- is benaderd vanult de roltheorle van Gerhart. Volgens deze theorie hoort drankgebruik thuls in situatlerolien. Situatierollen zijn te omschrlfven als de nomatleve verwachtingen van deelnemers aan situaties, waarin doeleinden worden nagestreefd die in de betreffende situatie worden verwezenlijkt. Met de plaatsing van drankgebruik in situatierollen wordt ook een begrenzing van drankgebrulk aangegeven. Algemeen gesproken kan worden gesteld dat s1tuatlerollen die een direkte behoefte bevredigen een adekwate ultvoering van (belangrijker geachte) positierollen niet in de weg mogen staan. Positierollen zijn te omschrifven als de normatieve verwachtingen gekoesterd op grond van de posttie die lemand inneemt in een organisatie of institutie.

De derde soort rollen zijn de zogeheten statusrollen, te onschrlfven als de verwachtingen die jegens lemand gekoes- 
terd worden op grond van de statuskenmerken die $h i j / z i j$ heeft. Van deze soort rollen is gesteld dat ze met name van invloed zijn op de selektle van sltuaties waarin men gewoon is te drinken. Ondat de statusrol de enkeling een meer omvattende en kontinue orlëntatie bledt hoe zich in een grote verscheldenheld aan sltuatles te gedragen, kan de statusrol aanwl fzingen bevatten voor het individu hoe drankgebruik als een betekenlsvol element in zijn leefwljze is op te nemen. De roltheorle biedt geen uitslultsel welke statuskenmerken samenhangen met gangbaar drinkpatroon. Op grond van de onderzoeksilteratuur werd echter als hypothese geformuleerd:

ex win verschizlen in gangbar crinkpatroon tussen statusgroeperingen gedefiniëerd door één of meer van de statuskenmerken geslacht, leeftijd, sociale klasse en godsdienst. 


\section{Intensivering van drankgebruik}

III. I. Inlelding

De probleenstelling die in dit hoofdstuk wordt besproken is eerder geformuleerd als "welke kondities en faktoren -anders dan die welke samenhangen met verschillen in gangbaar drinkpatroon- beInvloeden de kans dat het drankgebrulk geIntens1veerd wordt?".

Intensivering van drankgebruik wordt hier gebrulkt in de betekenis van een, vergeleken met andere leden van de onderzoekspopulatie, hoog konsumptienlvo. De term vergel1 jkenderwi Is impliceert dat de grens tussen nomaal geacht en intenslef drankgebrulk kan verschillen naar gelang de onderzoekspopulatie.

Konsumptientvo wordt hier gedefintëerd als het aantal standaardglazen alkohol dat lemand in een bepaalde tijdseenheld konsumeert. Er wordt geen onderscheid gemaakt tussen soorten drank: een standaardglas jenever telt even zwaar als een standaardglas b1er.

Een verschil van de hier gebrutkte omschrljving van konsumptient vo met de door andere onderzoekers gehanteerde "quant1ty frequency" indexen (Garretsen 1983; S1Jlbing 1978; Cahalan 1969; F1tzgerald en Mulford 1981) is dat de klassifikatle van drinkers naar konsumptienivo éénduldig is hetgeen, zoals reeds eerder is gesteld, bif andere amschrifvingen niet gegarandeerd is (Skog, 1981).

Bif de formulering van de probleemstelling is uitgegaan van de veronderstelling dat voorzover statusgroeperingen verschillen in konsumptientvo, deze verschillen gerekend moeten worden tot de in de betreffende samenleving normaal geachte verschilien in konsumptienivo.

Een voorbeeld; ult een studie van Phillpsen, e.a. (1983)

blijkt dat vrouwen in grote meerderheld een drinkpatroon kan worden toegeschreven dat zich kenmerkt door een laag konsumptienivo. BIj mannen domineren, variërend naar leeftijd en soclale klasse, drinkpatronen met en hoger konsumptlenfvo. Het hier aangehouden standpunt is dat het onzinnig is op grond van deze verschillen de vraag te stellen waarom mannen hun alkoholgebrutk 'gelntensiveerd' hebben. Zo er h1er een relevante vraag gesteld moet worden is het die naar de kulturele en strukturele kondities die ertoe lelden dat 
mannen en vrouwen verschilien in de warde en betekenis die ze aan drankgebrulk hechten.

Statusfaktoren dle samenhangen met drinkpatronen zullen desalnilettemin wel opgenomen worden in de analyse van intens1vering van drankgebrutk op konsumpt1enivo. Voomultiopend op het hoofdstuk waarin de analyse zal worden gepresenteerd, kan namel1 jk nu al gezegd worden dat de 1deale vorm van analyse, namell Jk die waarin apart voor statusgroeperingen met een relatief homogeen drinkpatroon wordt geanalyseerd of de verwachte verbanden zich voordoen, vanwege te klelne aantallen onuttvoerbaar 1s. De statusfaktoren die samenhangen met verschllien in drinkpatroon zullen derhalve als kontrole varlabelen in de analyse worden opgenomen. Dok om een inhoudel1jke reden zullen statusfaktoren dle samenhangen met verschlllen in drinkpatroon, opgenomen worden in de analyse. Intensivering van drankgebrulk moet mede afhankel1jk geacht worden van de betekenissen waarmee drankgebruik is ongeven. Een voorbeeld: bif een drinkpatroon dat zich beperkt tot drankgebrutk blj blyzondere gelegenheden, is het onwaarschlinlljk dat in het leven van alledag gelegen spanningen lelden tot intensivering van drankgebrulk. Zo niet bij een drinkpatroon waarbly dagel1jks wordt gedronken, hier moet het warschijnlljker geacht worden dat intensivering van drankgebmilk een voor de hand liggende manier wordt gevonden on spanningen te neutrallseren.

De bespreking van de faktoren die van invloed geacht worden op konsumptientvo zal begonnen worden met een heel speciaal geval van konsumptlentvo, namel1 Jk geheelonthouding. Daarna zal aangegeven worden voor welke faktoren op grond van de roltheorle een verband met intenslverlng van drankgebrulk wordt verwacht. Tot slot zullen twee andere varlabelen warvoor een verband verwacht wordt met intenslvering van drankgebrulk worden besproken te weten dagonderwl $\mathrm{js}$ volgen en gemeentegrootte.

\section{2. Geheelonthouding}

Zifn er slechts klelne, graduele verschlllen tussen geheelonthouders en drinkers of zIJn er grotere verschillen tussen 
deze twee kategorieën te konstateren? Dat is de vraag waarmee $1 \mathrm{k}$ me $1 \mathrm{n}$ deze paragraaf zal bezlghouden.

De vraas wordt in de eerste plaats on een praktlese reden gesteld. Zo geheelonthouders op relevante punten b111ken te verschlilen van drinkers, dan kan deze kategorle beter bulten beschouwing gelaten worden bif de analyses over drankgebruik. Aan deze praktiese reden kan een inhoudelijke reden worden toegevoegd: het inzlcht in het verschljnsel geheelonthouding wordt vergroot als voor een aantal faktoren nagegaan wordt of mensen, die minstens zes maanden geen alkoholhoudende drank hebben gedronken - dat is de hler aangehouden operationele definitle van geheelonthouding-verschillen van degenen die meer of minder regelmatig drinken.

De kenmerken waarvoor nagegaan zal worden of geheelonthouders en drinkers verschillen zijn:

- de statusfaktoren geslacht, leeft1 jd en soclale klasse

- specifleke redenen an niet te drinken

Ondat verschilien tussen geheelonthouders en drinkers geen centraal onderwerp in deze studie 1s, zullen reeds hier de resultaten gepresenteerd worden. Voor ultgebreldere analyses van de verschillen tussen geheelonthouders en drinkers in Limburg en Rotterdam zif verwezen naar het rapport Probleemdrinken in Limburg (Knibbe, 1982) het rapport Alkoholprevalentle onderzoek Limburg/Rotterdam (Garretsen, Knibbe, 1983) en de dissertatie 'Probleemdrinken' van Garretsen (1983).

\section{2. 1. Statuskemerken en geheelonthouding}

In Limburg gaf $16.5 \%$ van de respondenten op de laatste zes maanden of langer geen alkoholhoudende drank te hebben gedronken, in Rotterdam 19.5\%. Rotterdam benadert daamee meer het landel1.jk gemiddelde van 1981 blj de bevolking van 20 tot 65 Jaar: 21\% (Adriaanse e.a., 1981).

In LImburg en Rotterdam is het percentage geheelonthouders bif vrouwen groter dan bif mannen. Het verschil in deze tussen mannen en vrouwen is in Limburg echter groter dan in Rotterdam: $25 \%$ van de vrouwen en $8 \%$ van de mannen in Limburg is geheelonthouder. In Rotterdam z1jn deze percentages $25 \%$ en 13\%. Ook naar leeft1jd zijn er tussen Limburg en Rotterdam verschilien in percentages geheelonthouders tussen Lim- 
burg en Rotterdam. Voor Rotterdam geldt dat b1f mannen en vrouwen het hoogste percentage drinkers te vinden is in de leef t1 Jdsgroep 25-49 Jaar. In Limburg is het hoogste percentage drinkers bif mamnen en vrouwen te vinden in de leeft1.jdsgroep 16-44 jaar. In Limburg begint men klaarblijkelijk op jongere leeft1 jd met drinken. In Rotterdam zljn zowel de oudere als jongere leefti Jdsgroepen oververtegenwoordigd bij de geheelonthouders, in Limburg alleen de oudere leefti jdsgroepen.

B1j vrouwen in Limburg en Rotterdam en bif mannen in Rotterdam z1 Jn analoge verschillen in percentages geheelonthouders naar soclale klasse te vinden. In de hogere sociale klasse is het percentage geheelonthouders lager dan in de middenklasse, in de lagere soctale klasse wordt het hoogste percentage geheelonthouders gevonden. Adriaanse e.a. (1981) vinden voor een landelljke steekproef ook dat in de lagere soclale klasse het hoogste percentage geheelonthouders voorkomt. Casselman e.a. (1982) rapporteren dat in Belglë blj schoolgaande Jongeren ult de lagere klasse hogere percentages geheelonthouders worden aangetroffen. Mannen in L.1mburg, waar zlch geen verschtlien in percentages geheelonthouders naar soclale klassse voordoen, l1jken een ultzondering te zl In op de regel dat in de lagere soclale klasse een hoger percentage geheelonthouders wordt aangetroffen.

In een apart voor mannen en vrouwen in Iimburg en Rotterdam uitgevoerde diskrıminantanalyse blijken de variabelen leeftijd en sociale klasse bif te dragen aan de verklaring van het verschil tussen geheelonthouders en drinkers, ook als op de nog te bespreken, sterkere, samenhangen met gezondheldsIndikatoren wordt gekontroleerd. (zle ook Kn1bbe, 1982; Garretsen, 1983).

Een specifleke reden on nlet te drinken kan een slecht geachte gezondheld $\mathrm{zl} \mathrm{Jn}$. Voor drle gezondheldsindikatoren, te weten de skore op de verkorte VOEG-schaal (DIrken, 1967), het oordeel over de elgen gezondheld en het aantal dagen dat men het afgelopen half Jaar zlek 1 s geweest, is de samenhang met geheelonthouding nagegaan.

Het blijkt dat b1j mannen en vrouwen ouder dan 40 jaar ten aanzlen van twee of meer van de gezondheldsindikatoren de verwachte verbanden worden gevonden. Bid mannen en vrouwen Jonger dan 40 Jaar in Limburg en Rotterdam worden echter, op één ultzondering na, de verwachte verbanden nlet gevonden (zle bljlage I, tabel 1). 
Klaarblijkelijk gaan pas op oudere leeft1jd gezondheldsoverwegingen gewicht in de schaal leggen wat betreft de keuze wel of niet drinken. In een apart voor mannen en vrouwen uitgevoerde diskriminantanalyse blijken gezondheidsindikatoren (met name het oordeel over de elgen gezondheld) het sterkst bij te dragen aan de verklaring van verschillen tussen geheelonthouders en drinkers (zie ook Knibbe, 1982; Garretsen 1983).

Een groter of kleiner deel van de geheelonthouders ouder dan 40 jaar zlifn naar alle waarschlfnlljkheld mensen dle gestopt zijn met drinken. De toename van het percentage geheelonthouders in oudere leeftijdsgroepen (Knibbe, 1982; Garretsen, 1983), die blijkens longitudinale analyse van drankgebrulk (van Reek e.a.; 1983) nlet toegeschreven kan worden aan generatieverschilien, pleit daarvoor.

Een precieser inzlcht in de geldigheld van de gezondheidsoverwegingen, die mensen ertoe brengt te stoppen met drinken, $11 \mathrm{jkt}$ gewenst.

Dit temeer daar in verband met de $b 1 f$ geheelonthouders gekonstateerde grotere kans op een hartinfarkt (Klatsky, 1983, Knipschild, 1982) gesproken is over '...enkele duizenden hartinfarkten die niet nodig zifn' (Knipschild, 1982). Zolang er geen precieser inzicht is in de geldigheld van de gezondheldsoverwegingen die mensen ertoe brengt te stoppen met drinken, zou mijns inziens dit soort uitspraken beter niet gedaan kunnen worden.

Samenvatting

Er zifn verschilien tussen geheelonthouders en drinkers te konstateren wat betreft geslacht, leeft1jd, soclale klasse, en gezondheidsindikatoren. De genoende verschillen tussen drinkers en geheelonthouders rechtvaardigen het de geheelonthouders buiten de analyse over drankgebrutk en de gevolgen daarvan te houden. 
III. 3. 1. Roltheorle en kondities die lelden tot intensivering van drankgebrulk

Vanult de roltheorle is de vraag naar kondities die leiden tot Intensivering van drankgebrulk de vraag naar de faktoren, die de kans beInvloeden dat situatlerollen waarin drank wordt gebrulkt, worden uitgebreld en/of geIntensiveerd. U1t de roltheorle kan afgeleld worden dat bif mensen in posities waaraan rollen verbonden $z 1 j n$ dle het dagelljks leven slecht struktureren, de kans op intenslvering en/of uitbreldins van sltuatlerollen het grootst is.

Toegespltst op drankgebrulk zijn aan deze verhoogde kans twee aspekten te onderschelden:

- er is een grotere gelegenheld tot drankgebrulk, omdat de tijasbesteding in mindere mate bepaald wordt door het nakomen van verplichtingen gelegen in de positierol.

Deze grotere kans geldt voor alle positlerollen die het dagelljks leven welnis struktureren.

- situatlerollen waarin drank wordt gebmulkt kunnen aangewend worden $\mathrm{om}$, zif het gebrekkiger dan positierollen dit doen, betekenls en struktuur aan het dagelljks leven te geven.

De kans hlerop is naar alle waarschl.jnlljkheld verschillend naargelang de betekentssen waarmee drankgebrulk is omgeven, 1.c. verschillend voor statusgroeperingen die verschtlilen in gangbaar drinkpatroon. Hlerop is in de inlelding van het hoofdstuk al in gegaan.

Een andere faktor, die mogelijk beinvloedt of bif een groepering met een weinig gestruktureerd dagel1jks leven, intenslvering van drankgebrulk optreedt, is de gezondheldstoestand. Het 11 jkt me aannemelifk dat in groeperingen dle zowel gekenmerkt worden door een welnig gestmuktureerd dage11.jks leven, alsook door een vergel1 jkenderw1 Is slechte gezondheld (1.c. arbeldsongeschikten), de tendens tot intensivering van drankgebrulk zich nlet of minder zal voordoen.

U1t het voorgaande kan als hypothese afgeleld worden: een weinig gestruktureerd dagelijks leven, zal de kans op intensivering van drankgebruik doen toenemen. 
Daarbif zijn twee kondities aangegeven waaronder deze hypothese niet hoeft op te gaan:

- statusgroeperingen die verschillen in gangbaar drinkpatroon, kunnen verschillen in de mate waarin een weinis gestruktureerd dagelijks leven leldt tot intensivering van drankgebruik.

- bij groeperingen die zowel gekenmerkt worden door een vergelijkender wljs weinig gestruktureerd dagelljks leven, alsook door een slechtere gezondheid, zal geen of In mindere mate intensivering van drankgebruik optreden. De indikatoren voor de mate van strukturering van het dage$11 \mathrm{jks}$ leven worden ontleend aan werk- en gezinssituatle. Het hebben van arbeldsverplichtingen butten gezinsverband, het samenleven met een partner en de zorg voor thuiswonende kinderen, worden opgevat als indlkatoren voor verplichtingen die struktuur geven aan het alledaags handelen. Deze drle Indikatoren zullen gekombineerd worden tot één variabele, 'strukturering van het dagelljks leven'. De skore op deze variabele kan variëren van mul -geen werk, geen partner, geen zorg voor thuiswonende kinderen- tot drle: werk, partner en zorg voor thulswonende kinderen. (z1e hoofdstuk VII voor de praktiese uitwerking).

In de twee hternavolgende subparagrafen zal echter om verscheldene redenen op werk- en gezinssituatle afzonderlifk Ingegaan worden. Ten eerste komt in de literatuur over alkoholgebrulk de komblnatle van aspekten van werk- en gezinssituatie tot één variabele niet voor. Ten tweede zullen in deze studie, behalve een analyse van de invloed van strukturering van het dagelifks leven, ook analyses gepleegd worden voor verschillen in konsumptle naar werk- en gezlnssituatie afzonderlijk. Hoewel deze analyses, gegeven het theoreties raamwerk waarmee hler wordt gewerkt, niet noodzakelijk z1jn, maken ze het mogelifk de ultkomsten te spec1flceren.

III. 3.2. Werks1 tuatie

In de werksituatie worden al die posities waraan geen arbeidsverplichtingen buiten het gezin verbonden $z 1 \mathrm{Jn}$, gerekend tot de positles met rollen die weinlg struktuur geven aan het dagelijks leven. Respondenten die op een vraag naar 
werksltuatle opgaven rkzoekend, arbeldsongeschlkt of gepensioneerd te $\mathrm{zl} \mathrm{fn}$, wordt derhalve een, vergeleken met werkenden, minder gestruktureerd dagel1.1ks leven toegeschreven.

Vrouwen die op de vraag naar werksltuatle opgaven "hulsvrouw" te zlin worden, voorzover de alskussie zlch beperkt tot de invloed van de werks1tuatie, gerekend tot de werkenden.

D1t vanult de veronderstelling, dat b1j vrouwen die opgaven werkzoekend, arbeldsongeschikt of gepensioneerd te $\mathrm{zl} \mathrm{fn}$, het dagel1 jks leven minder gestruktureerd is door pos1tierolverwachtingen dan b1 vrouwen die opgaven hulsvrouw te $z 1 \mathrm{jn}$. Voorzover de ind1katoren in werk- en gezinssituatie tot een varlabele, "strukturer1ng van het dagel1 Jks leven" gekomb1neerd worden (zle hoofdstuk VII), zal het hebben van arbeldsverplichtingen bultenshuls bif vrouwen op dezelfde wIfze als indikator gebrulkt worden als bif mannen.

Behalve posities die zich kermerken door het ontbreken van een arbeldsrol, zifn er ook posities waarvan de verplichtingen niet noodzakel1jkerw1js met regelmaat nagekomen hoeven te worden. Aan degenen die dagonderwl $J \mathrm{~s}$ volgen wordt wel eens zo' $\mathrm{n}$ vrljheld toegeschreven. Maar ook bepaalde beroepsrollen worden gekenmerkt door een relatlef grote vrl theld: schrlfver, kunstschllder, Journalist. Of degenen die dagonderwl fs volgen een, vergeleken met werkenden intenslef drankgebmulk kennen, zal in deze studle worden nagegaan.

De gegevens laten echter nlet toe na te gaan of b1j respondenten met beroepsrollen dle welnig struktuur geven aan het dagel1jks leven, sprake is van een vergel 1jkenderwl js intenslef drankgebruik.

Aangaande de vergel1 Jking van onderwl jsvolgenden met werkenden zal geen hypothese worden geformuleerd. Ondanks dat in onderzoek naar drankgebrulk b1j untversite1tsstudenten (Janssen en Voestermans, 1978; van Rooyen, 1981) en scholleren ( $v$. d. Wal, 1984) erop werd gewezen dat degenen die dagonderwijs volgen een hoog konsumptienlvo hebben, waag ik het te betwijfelen of het hoger is dan werkenden van vergelijkbare leeft1jd. Deze twljfel heb ik niet alleen omdat $1 \mathrm{k}$ niet zonder meer wens aan te nemen dat degene die dagonderwi fs volgen vergeleken met werkenden minder verplichtingen hebben dLe hun dagel1Jks leven struktureren. Vaak zullen degenen Ale dagonderwljs volgen ook minder geld beschikbaar hebben dan werkenden, en dit kan ook van lnvloed zlJn op de alkoholconsumptie. 
In de literatuur zifn voomamel1jk aanwljzingen te vinden voor samenhangen tussen arbeldsloos bestaan (1.c. werkzoekend, arbeldsongeschikt en gepenstoneerd) en drankgebrulk. Een recent rapport in Nederland waarin ook alkoholgebrulk ter sprake kont, Leeft Nederland Oké? (Adriaanse e.a., 1981), 11jkt resultaten op te leveren dle afwijken van wat hier verondersteld wordt. Gevonden wordt dat door ekonomles nlet-aktieven (arbeldsongeschikten, langdurlg werkzoekenden en vervroegd gepensioneerden) nlet vaker 6 of meer glazen per keer wordt gedronken dan door een representatleve steekproef van de bevolking.

Toch kan deze uitkomst geen reden zifn on nu al de hypotheses te verwerpen. Een vergelljkenderwljs hoog konsumptienivo hoeft niet tot uitdrukking te komen in een groter aantal keren dat 6 of meer glazen per keer wordt gedronken.

Grosveld en van Oyen (1982) presenteren andere ultkonstien. Hun onderzoeksgroep betreft mannelljke automobilisten aangehouden onder verdenking van het rijden onder invloed. Nemen we bloed-alkoholgehalte als ind1kator voor konsumptienivo, dan blijken met name de arbeldsongeschikten zich te kermerken door een hoog percentage (28.3\%) dat een promillage had van meer dan $20 / 00$. B1j de werkende en werkzoekende aangehouden mannen was dit respektlevel1 jk $15.3 \%$ en 13.5\%. De werklozen bl1jken zlch wat betreft deze indikator voor konsumptienivo niet te onderschelden van werkenden. Werkzoekenden bl1jken echter wel, evenals arbeldsongeschikten, gemiddeld hoger te skoren dan werkenden op een screeningstest voor probleemdrinken, naar ik vermoed mede amdat ze gemiddeld meer drinken.

Wat hierbil opvalt is dat arbeldsongeschikten zich sterker dan werkzoekenden onderscheiden van werkenden. Men zou verwachten dat bil arbeldsongeschikten gezondheldsoverwegingen zouden leiden tot matig gebrulk. De verklaring is wellicht dat de betreffende onderzoeksgroep geen a-selekte steekproef vormt van de werkende en ekonomles nlet-aktleve bevolking. De verklaring die deze onderzoekers geven voor de mate waarin probleemdrinken bif arbeldongeschikten voorkomt, wil $1 \mathrm{k}$ toch aanhalen andat deze in het verlengde $11 \mathrm{gt}$ van de hier aangehouden theorle: 'men $\mathrm{krljgt}$ een zlekte, aandoening of bl1fvende handicap, kan zifn werk niet meer aan, wordt op den duur ultgestoten ult het arbeldsproces, verliest $z 1 . j n$ soclale kontakten bulten het gezin en zoekt zifn hell in kontakten bultenshuls, waarb1j de kans op alkoholgebruik 
groelt'. Werkzoekenden zouden wat dit betreft nog beter af z1.Jn volgens de auteurs ondat deze nog ultzlcht hebben op een "nomale" arbeldsrol. Desondanks geldt voor zowel werkzoekenden als arbeldsongeschikten dat een hoger percentage (respekt1evel1jk 22.1\% en 26.9\%) dan b1j de werkenden

(16.5\%) al voor de middag begint te drinken. Dit is een duldel1Jk teken van ultbrelding van situatierollen waarin drank wordt gebmulkt.

Wat betreft bultenlands onderzoek kan 0. a. verwezen worden naar resultaten van Armor e.a. (1976). Z1f vonden voor een representatieve steekproef van de bevolking in de V.S. dat werklooshe1d en ongehuwd $21 . j n$ (waarover straks meer) bijdragen aan de verklaring van een hoger konsumoptienivo, ook na kontrole op geslacht, leeftijd en soctale klasse.

Het interessante van deze ultkomst is dat in 1eder geval op een aantal statuskemmerken, die naar $1 \mathrm{k}$ veronderstel samenhangen met verschilien in drinkpatroon, is gekontroleerd.

\section{3. 3. Gezinssituatie}

In de gezinssituatie zijn zoals gezegd twee indikatoren voor de mate van strukturering van het dagelljks leven aan te wlfzen: het samenleven met een partner en de zorg voor thulswonende kinderen.

Het samenleven met een partner en de zorg voor thulswonende kinderen zullen, waar gezinssituatie op zich ter diskussle staat gekombineerd worden tot één varıabele die de volgende kategoriën heeft:

- zonder partner

- met partner, zonder kinderen

- met partner en thulswonende kdnderen

- met partner en bultenshuis wonende kinderen.

De kategorie zonder partner betreft niet alleen nooft gehuwden, maar ook gescheldenen en degenen wler partner is overleden en die niet hertrouwd zilfn.

Vergeleken met degenen die samenleven met een partner kan van allen zonder partner gezegd worden dat ze in hun thuissituatle minder rekening hoeven te houden met andere volwassenen. In dat opzicht kan voor allen zonder partner de gelegenheld tot drankgebrulk groter geacht worden. Tussen dege- 
nen zonder partner kan er echter verschil zijn of er wel of geen kinderen zlJ $n$. Heeft men geen partner echter wel zorg voor klnderen, dan is er geen sprake van een positierol die het dagel1 $\mathrm{Jks}$ leven weinlg struktureert. In de analyse zal dit punt buften beschouwing gelaten worden ondat de aantallen respondenten in de kategorle zonder partner het niet toelaten dit punt bif de analyse te betrekken.

Degenen zonder partner kunnen ook op een tweede punt onderling verschillen. BIf gescheldenen en oudere noolt gehuwden kunnen, anders dan bif jongere noolt gehuwden en weduwes/weduwnaars gevoelens van onvermogen on een relatie te kontinueren (gescheldenen) dan wel een duurzame relatle aan te gaan (oudere noolt gehuwden) aanwezig zijn. Mogel1jk dat deze gevoelens de aanlelding zijn tot een grotere behoefte aan drinksituaties waarin deze gevoelens geneutrallseerd kunnen worden.

De laatst besproken verschillen tussen degenen zonder partner worden belangrijk genoeg geacht on -voorzover mogelijkin specifleke analyses aan te houden.

Zeker bif vrouwen, mogelijk ook bif mannen, moet het al dan nlet hebben van kinderen en of deze thulswonen van invloed worden geacht op de verplichtingen die in de gezinsrol zijn vervat.

Zonder thulswonende kinderen ziJn er minder positierolverplichtingen dan met thuiswonende kinderen. Verder kan er nog verschil zifn naar gelang de zorg voor kinderen is weggevallen (1.c. waar de kinderen ult huls zijn), dan wel dat er (nog) geen kinderen z1.jn. De gelegenheld tot drankgebrulk mag in belde situatles overeenkomstig $\mathrm{zIJn}$, wellicht dat bif het wegvallen van verplichtingen die voorheen, met name bij vrouwen, betekenis gaven aan het alledaags handelen, sprake is van een sterkere behoefte om situatierollen te intensiveren dan wel uit te brelden. In de analyse zal hlerop worden lingegaan.

Aangaande onderzoek in Nederland is $\mathrm{mlj}$ alleen bekend dat Schlppers (1981) meldt dat er tussen gehuwden en ongehuwden geen verschil is in percentages excessleve of probleemdrinkers.

Bif sekondalre analyse op gegevens afkomstis ult onderzoek van Gadourek (1963), Jessen (1970) en Adriaanse e. a. (1981), blifkt dat in Nederland, op één ultzondering na, reeds ge- 
ruime tifd in de leeftifdskategporle 20 tot 30 jaar de ongehuwden gemiddeld méér drinken dan gehuwden.

\begin{tabular}{|c|c|c|c|c|}
\hline & \multicolumn{2}{|c|}{ MAWNEN } & \multicolumn{2}{|c|}{ VROUNBN } \\
\hline & onsehuwd & gerumw & ongeruxt & genatiod \\
\hline 1958 & 5.7 & 3.7 & 1.7 & 1.5 \\
\hline 1970 & 16.0 & $12 \cdot 5$ & 4.7 & 3.5 \\
\hline 4981 & 10.6 & 11,6 & 6.1 & 4.4 \\
\hline
\end{tabular}

De ultzondering z1jn de ongehuwde mannen in 1981 die, opmerkel1 Jk genoeg, lets minder dan gehuwde mannen drinken. Voor oudere ongehuwden $z 1 \mathrm{Jn}$ geen gegevens voorhanden.

Ferder is reeds de bevinding van Armor e.a. (1976) aangest1pt, namel1jk dat na geslacht, leeft1jd en soc1ale klasse ook burgerlifke staat bifdraagt aan de verklaring van de varlantie in konsumptienivo. Ongehuwden drinken meer dan gehuwden. De gegevens die Cahalan e.a. (1969) presenteren maken het mogelljk de bevindingen van Armor e.a. konkreter in te vullen. Uit de resultaten van Cahalan e.a. blijkt dat

- b1j gescheldenen, ook als gekontroleerd wordt op geslacht en leeftijd, een hoger percentage zware dminkers is te vinden dan bif gehuwden,

- bif de noolt gehuwden een hoger percentage zware drinkers is te vinden dan bil de gehuwden in overeenkomstige geslacht en leeftijdskategorleèn,

- bij de weduwen en weduwnaars een lager percentage zware drinkers is te vinden dan b1j gehuwden in de overeenkomstige geslacht- en leeft1 jdsgroepen.

De verschillen tussen gescheldenen en gehuwden in percentages zware drinkers zljn groter dan die tussen noolt gehuwden en gehuwden.

Dok de Invloed van het al dan niet hebben van thulswonende kinderen is door Cahalan e.a. nagegaan. In tegenstelling tot de hier geufte verwachting, melden alf dat bij vrouwen met 
thulswonende kinderen, een hoger percentage tot de 'heavy drinkers" gerekend moet worden dan bif vrouwen zonder thuiswonende kinderen. De auteurs geven als mogelljke verklaring aan dat de spanningen van de zorg voor en het opvoeden van kinderen zwaarder wegen dan de wens het goede voorbeeld te geven aan kinderen die nog thuls wonen. Tussen mannen met en zonder thulswonende kinderen bleken overigens geen relevante verschillen in konsumptle te aljn.

\section{II.I. 4. Gemeentegrootte en konsumptientvo}

U1t onderzoek in de Verenigde Staten komt de gemeentegrootte (gedefintëerd in termen van aantal inwoners) konsekwent naar voren als een faktor die het konsumptienivo beinvloedt. In grotere steden wordt meer gedronken dan in kleinere gemeenten of op het platteland (Mulford, Miller, 1963, Cahalan, e.a. 1969).

Cahalan e.a. utten als vermoeden dat de sociale kontrole in steden zwakker is dan in klelnere gemeenten en op het platteland. Daardoor is in grote steden de mogel1Jkheld am onopgemerkt veel te drinken groter dan in klelne gemeenten. Naast deze verklaring moet wat betreft de Verenlgde staten van Amerika minstens nog één andere genoemd worden.

Fitzgerald en Mulford (1981) rapporteren dat tussen 1958 en 1981 in Iow (V.S.) het versch1l in konsumptie tussen 'farm residents' en inwoners van gemeenten met meer dan 2500 Inwoners fors is afgenomen. Zif geven als verklaring dat de verkrljgbaarhe1d van drank voor 'farm-residents' in deze perlode sterk is toegenomen.

In twee landen waar voorzover ik weet geen relevante verschillen in verkrljgbaarheld van drank naar gelang gemeentegrootte bestaan, zijn echter nog recent verschilien in drankgebrulk naar gelang Inwonersaantal gekonstateerd. Voor Belgle wordt door Casselman e. a. (1982) gerapporteerd dat schoolgaande jongeren ult Brussel beduldend meer drinken dan schoolgaande jeugd utt kleinere steden als Leuven en Gent.

Voor Nederland maakt Sijlbing (1978) een zljdelingse opmerking. HIj vindt klelne verschillen in percentages geheelonthouding naar urbanisatiegraad (gedefiniëerd aan de hand van de C.B.S.-typologle). Opvallend is dat in plattelandsgemeen- 
ten een klelner percentage geheelonthouders is te vinden (14\%) dan b1 Jvoorbeeld in de grote steden (20.5\%).

Vergel1jken we een grote stad als Rotterdam met een reg1o die voomamel1jk bestaat ult kleinere gemeenten, Limburg, dan is in Limburg de gemlddelde konsumptle per hoofd van de bevolking (11.6 glazen per week) hoger dan in Rotterdam ( 9.3 glazen per week).

Een storende faktor is echter dat Limburg een dominant katholleke reglo is en van katholleken is bekend dat ze meer drlnken dan protestanten (Gadourek, 1963, S1flbing, 1978, van Reek e.a. 1983).

Nu stelt Drop (1979), de traditle van Durkheim (1965) volgend, dat een "toenemend soclaal volume" (te indiceren door aantal Inwoners) gepaard gaat met een grotere interakt lefrekwent1e. Deze leidt tot "een naar verhouding geringere intensitelt van de interakties en dearmee tot een veriles aan belangstelling voor andermans doen en laten en een verslapping van de collectleve survelllance". (Drop, 1979). Er is geen reden on aan te nemen dat dit niet óók voor een dom1nant katholleke reg 10 als Limburg geldt.

Als hypothese wordt dan ook aangehouden:

in Limburg is in grote gemeenten het gemiddeld konsumptienivo hoger dan in kiteine gemeenten.

OverIgens wordt er in deze hypothese st1lzwijgend van uitgegaan dat de in kleinere gemeenten groter geachte belangstelling voor andermans doen en laten tot uitdrukking komt in het sneller afkeuren van veel drinken. Is er echter sprake van nomen die Julst aanzetten tot drinken -bv. cafëbezoek In het weekend, rondjes geven (en $\mathrm{krlj}$ jgen), niet achterbl1 jven met drinken- dan kan de in kleinere gemeenten groter geachte belangstelling voor de ander ook lelden tot een gemlddeld hoger konsumptlenivo. Anders gezegd: Blj één of meer statusgroeperıngen kan drankgebruik een dusdanig benadrukt stljlelement van de statusrol zl Jn, dat de in kleinere gemeenten groter te achten sociale kontrole, leldt tot een verge 11 Jkenderw Is hoog konsumptlentvo.

B11 de analyse zal moeten blljken of Inderdaad aan het mogel1Jk bestaan van deze normen voorb1jgegaan mag worden. 


\section{Samenvatting}

De probleemstelling met betrekking waartoe in dit hoofdstuk hypothesen geformuleerd zljn, luldt: Welke konditles en faktoren, anders dan die samenhangen met verschillen in gangbaar drinkpatroon, beinvloeden het konsumptlenlvo?

Vanult de roltheorle is als algemene hypothese af te lelden: een weinig gestruktureerd dagelijks leven zal de

kans op intensiveming van situatierolten warin drank wordt gebruikt, doen toenemen.

BIj deze hypothese zIjn twee beperkende kondities geformuLeerd:

- statusgroeperingen die verschillen in drinkpatroon kunnen verschillen in de aanwezigheld dan wel sterkte van het verwachte verband.

- in groeperingen waar een welnig gestruktureerd dagel1jks leven wordt gekombineerd met een vergelifkenderwl is slechte gezondheldstoestand, vindt mogel1jk geen 1ntensivering of ultbreiding plaats van situatierolien waarin drank wordt gebrutkt plaats.

De indikatoren voor posities met rollen die het dagelijks leven struktureren, zijn gezocht in werk- en gezinssituatie. In de werksituatie wordt het hebben van arbeidsverplichtingen bulten het gezin als indikator voor de mate van strukturering van het dagelljks leven opgevat. In de gezinssituatle het samenleven met een partner en de zorg voor thuiswonende kinderen. Deze drie indikatoren zullen gekomb1neerd worden tot één variabele "strukturering van het dage$11 \mathrm{jks}$ leven", waarvoor nagegaan zal worden of er sprake is van de verwachte invloed op konsumptienivo. Tevens zal, voorzover mogelijk, voor de onderschelden kategorleën in werk- en gezinssituatle afzonderlijk nagegaan worden of er relevante verschillen in konsumptientvo zifn. Wat betreft werks ltuatie 1 s daarb1 $\mathrm{J}$ een aandachtspunt of bil degenen die dagonderwljs volgen sprake is van een, vergeleken met werkenden, intensiever drankgebrutk. B1j de analyse voor gezinssituatie zal, waar mogelljk, nagegaan worden of blj zowel noolt gehuwden, gescheldenen als weduwes/weduwnaars de verwachte verschilien in konsumptle met degenen mét een partner zich voordoen. Tevens of er verschillen zl fn tussen gehuwden zonder (thuls- of bultenshuls wonende) kinderen en gehuwden met buitenshuis wonende kinderen.

Ten aanzlen van nog een andere varlabele dan de hlervoor 
genoemde 1 is een hypothese geformuleerd:

in Limburg is in grate gemeenten het ge-

middeld konsumptienivo hoger dan in

kleine gemeenten.

In kleine gemeenten mot namel1 Jk de soclale kontrole groter geacht worden, weshalve een vergel1 jkenderwl Js hoog konsumptlenlvo sneller afkeuring oproept.

Wel moet ter relativering van voorgaande redenering toegevoegd worden dat daar waar gedeelde normen bestaan dle aanzetten tot drankgebrulk, de in klelne gemeenten sterker te achten sociale kontrole julst tot een gemiddeld hoger konsumptienlvo kan lelden. 


\section{Nadelige gevolgen van drankgebruik, zorgen en afkeuring}

In dit hoofdstuk worden de laatste twee probleenstellingen vanult theoretles perspektlef ultgewerkt.

Ferst zal aandacht gegeven worden aan de probleemstelling 'welke andere varlabelen dan konsumptienivo belnvloeden de kans dat drankgebrutk gepaard gaat met schadelifjk te achten gevolgen?'

Vervolgens zal aangegeven worden welke andere faktoren dan schadelifk te achten gevolgen van drankgebrulk de kans beInvloeden dat drankgebrutk negatleve reaktles utt de omgeving oproept en/of zorgen bif de drinker zelf.

IV.1. Gevolgen van drankgebruik: begripsomschrijving

Onder het etiket gevolgen van drankgebrulk kan een zeer grote verscheldenheld aan verschijnselen worden samengevat: alkohollese levercirrose, ongevallen vanwege drankgebruik, met drankgebrutk samenhangende aandoeningen als slokdarmkanker, maagzweren, en de verschijnselen die tijdens of kort na excesslef drankgebrulk optreden: dronkenschap, tremoren, black-outs, e.d. (z1e o.a. Bruun e.a., 1975; WilkIns, 1974; Cahalan, 1976).

De omschrifving van nadelige gevolgen van drankgebrutk in deze studie, onvat slechts een gedeelte van alle nadelige gevolgen, namel1jk: t1jdens of na het drankgebrulk optredende verschijnselen die een adekwaat funktioneren van de drinker in enigerlei opzicht nadelig belnvloeden en door de gebrutker of mensen in ziJn leefomgeving gezlen worden als gerelateerd aan drankgebrulk.

De beperking betreft het felt dat de drinker zelf of mensen uit zi.jn leefomgeving het drankgebruik moeten herkennen als bron van verstoord funktioneren. Fen beperking die een praktlese reden heeft: de respondent moet zelf kumnen rapporteren welke nadelige gevolgen door hem of door anderen aan zifn drankgebmulk worden toegeschreven. Zou deze beperking in de amschrifving van nadelige gevolgen worden losgelaten, 
dan zljn onbetrouwbare meldingen te verwachten. Immers voor zover alkoholgebrulk leidt tot $b . v$. leverclrrose of een maagzweer, is het zeer goed mogelifk dat de drinker zelf of mensen uit zifn omgeving het verband tussen aandoening en drankgebrulk niet leggen. Voorzover de arts deze relatie onderkent, is er nog een grote kans dat deze dit niet of nlet duidelljk aan de patient vertelt (W1lkins, 1974; Hore en Wilkdns, 1976; van Dijk, 1978).

De vraag doet zich hierb1j voor of er drankgebrulk is dat vrijwel niet gepaard gaat met door de drinker zelf of door anderen herkende gevolgen, echter vanult medlese optlek schadelljk genoemd moet worden. Het is een vraag die men in de 11teratuur terug vindt als de korrespondentle tussen het, in deze studie aangehouden, "soclologlese" model voor alkoholmisbrulk en het "mediese" model.

Va1llant e.a. (1982) zifn nagegaan in hoeverre er overeenstermig is tussen een medische en gedragswetenschappelijke omschrifving van alkoholmisbrulk. Deze auteurs komen tot de konklusle dat de twee omschrijvingen elkaar empiries gezlen voor een zeer groot deel overlappen.

Toch blifven er twijfels, vooral als de gedachte wordt loslaten dat er een éénduldige mediese definitle van alkoholmisbruik is te geven. Wordt namelijk gekeken naar de drinkers die voor alkoholproblemen worden behandeld, dan kan een aantal typen alkoholisten worden onderschelden (Evenson e. A., 1973; Gibbs, 1980; Peters, 1982). Zo onderscheldt Peters (1982) na clusteranalyse van een groot aantal kermerken van opgenomen probleemdrinkers, drie typen: de uft de hand gelopen gewoontedrinker, de essentielle alkoholist en de defensleve alkoholproblematikus. Van het type, door hem benoemd als ult de hand gelopen gewoontedrınker, kan gesteld worden dat het een vorm van probleemdrinken betreft die nlet of moell1jk met een gedragswetenschappellijk model voor alkoholmisbruik geIdentificeerd wordt. Het voornaamste kenmerk b1j deze drinkers is namelijk het vóórkomen van leverclrrose én het ontbreken van verschijnselen als black-outs, tremors, dronkenschap e.d. Laatst genoemde verschifnselen ziJn, in tegenstelling tot levercirrose, in het gedragswetenschappelijk model voor alkoholmisbruik belangrijke indikatoren voor gevolgen van drankmisbruik. Het optreden van levercirrose wordt niet systematies nagevraagd vanwege eerder genoemde reden: de betrouwbaarheld van meldingen hlerover van de drinker is twiffelachtig. Gezien het voor- 
gaande is de velligste aanname, dat er en groep drinkers is voor wle de hierna te ontwikkelen hypothesen over de relatie tussen konsumptie en nadelige gevolgen nlet goed te ver1flëren zljn. Uit de resultaten van Peters blijkt dat de uit de hand gelopen gewoontedrinker vooral te vinden is bif mannen ult de hogere klasse. Met name voor deze populatle geldt de hiervoor geformuleerde beperking.

Er zifn drie groepen faktoren die van invloed kunnen worden geacht op de kans dat drankgebruik leldt tot nadelige gevolgen:

- het konsumptienivo, maar meer in het bijzonder de wljze waarop wordt gedronken, 1.c. het drinkpatroon

- de drinkgeschledenis

- de sociale situatie van de drinker

IV.2.1. Drinkpatroon

Naarmate men meer drinkt is de kans groter dat het drankgebrulk gepaard gaat met nadelige gevolgen. Ik neem aan dat dit verband, ook al omdat het in alle studies bevestigd wordt, niet nader verklaard hoeft te worden. Ook een volgende stap: konsumptientvo is sterker dan andere faktoren van invloed op de kans dat drankgebrulk gepaard gaat met nadelige gevolgen, behoeft naar ik aanneem geen nadere verklaring. BIf de daarop volgende stap echter, namelifk andere faktoren dan konsumptienivo die van Invloed kunnen zijn op de kans dat nadelige gevolgen optreden, komen we op een terrein waar nauweli.jks emplries onderzoek is gepleegd, en waar minder vanzelfsprekendheden $\mathrm{zI} \mathrm{jn}$.

De Invloed van drinkpatroon op de kans dat nadelige gevolgen van drankgebrulk optreden, kan met een voorbeeld verdu1del1jkt worden. Een zelfde aantal glazen per week, b1jvoorbeeld 20 glazen, kan op tenminste twee verschillende drinkpatronen wIJzen: een drinkpatroon waarbil op twee weekenddagen 10 glazen per keer wordt gedronken en een drinkpatroon waarbif op ledere dag van de week ongeveer drie glazen wordt gedronken. B1 $\mathrm{j}$ een drinkpatroon van twee maal per week 10 glazen moet de kans op nadelige gevolgen van drankgebruik als dronkenschap, kater, symptomen van excesslef gebruik, groter worden geacht dan b1j een drinkpatroon waarin de konsumptle wordt gespreld over de zeven dagen van de week. 
Fir zal dan cok nagegaan worden of populatles die verschillen in drinkpatroon, ook verschillen in de kans dat bij overeenkomstig konsumptlenivo, nadelige gevolgen van drankgebruik optreden. De hypothese luidt:

statuggroepemingen, die verschitlen in dminkpatroon,

kunnen verschilzen in de mate waarin bij overeen-

komstig konsumptienivo, nadelige gevolgen van

drankgebruik voorkomen.

In de mij bekende literatuur zifn slechts schaarse aanwljzingen te vinden voor de invloed van het drinkpatroon op nadelige gevolgen van drankgebrutk.

Cartwright e.a. (1978) vonden bif survey-onderzoek in een voorstad van London dat '...different age, sex and occupational groups reported different problemscores for similar levels of total consumption". Vervolgens tonen ze aan dat deze verschillen gedeeltelljk teruggaan op verschillen in drinkpatroon: naar gelang een gel1Jk aantal glazen over een kleiner aantal dagen van de week wordt gekonsumeerd, is de kans op nadelige gevolgen groter.

B1j kontrole op zowel konsumptlenivo als de frekwentie van arankgebmulk echter bl1 jkt, dat jongeren en respondenten u1t de lagere soclale klasse nog steeds vaker nadelige gevolgen van drankgebrulk melden dan respektlevel1jk ouderen en respondenten utt de hogere soclale klasse. De auteurs veronderstellen dat de leefomstandigheden van ouderen en van respondenten ult de hogere soclale klasse beter beschermen tegen de nadelige gevolgen van drankgebrulk.

De tweede aanwljzing is te vinden bly skog (1983) die op grond van theoretlese overwegingen als hypothesen formuleert dat naast konsumptienivo ook het drinkpatroon en cultureel bepaalde verwachtingen over drankgebrulk van invloed $z 1$ In op de kans dat drankgebrulk gepaard gaat met nadellge gevolgen. Belde hypothesen worden bevest1gd in een studie van Hauge en Irgens-Jensen (1984) die het drankgebrulk in FInland, Zweden, Noorwegen en IJsland vergeleken. $21 \mathrm{~J}$ vinden dat in IJsland, waar vergeleken met de andere skandinaviese landen de gemiddelde Konsumptle lager is, vaker nadelige gevolgen voorkomen. De onderzoekers maken aannemel1 Jk dat in IJsland, sterker dan in de andere Skandinaviese landen, de "roes" een kultureel akseptabel doel van alkoholgebrulk 1s. Tevens dat dit in IJsland leldt tot een drinkpatroon waarin vergeleken met de andere Skandinavlese landen, de frekwentle van drank- 
gebrulk laag is, de hoeveelheld die per keer wordt gedronken echter zeer hoog.

Onduldelljk is hoe in de theorle die de laatste jaren veel aandacht heeft gekregen, het zogeheten 'single distribution model (Ledermann, 1964, Popham e.a., 1976, de Lint en Schmidt, 1968, 1971, Bruun e.a., 1975, Cartwright e.a. , 1978; Fitzgerald, Mulford, 1981) wordt gedacht over de invloed van drinkpatroon c. q. soclale kermerken samenhangend met drinkpatroon, op nadelige gevolgen van drankgebrulk. Fén van de belangriflkste, zo niet dé belangrijkste hypothese van dit model is dat er een vaste relatie is tussen het gemiddeld konsumptientvo per hoofd van de bevolking en de proportie excessieve drinkers.

De onderzoeker, die als grondlegger van de in dit model besloten gedachtengang beschouwd mas worden, Ledermann (1964), heeft als kwallfikatie aan de veronderstelde vaste relatie tussen gemiddeld konsumptientvo en percentage excessieve drinkers toegevoegd, dat deze uitsluitend geldt voor populaties met een homogeen drinkpatroon. Opmerkelifk genoeg is er ondanks deze opmerking, nauwel1 Jks onderzoeksmaterlaal gepresenteerd (ook nlet door Ledermann zelf) waarult blijkt dat bij verschillen in drinkpatroon ook verschillen optreden in de relatie tussen gemiddeld konsumptienivo en proportile excessleve drinkers. De ultzondering is hier Skog (1977) die stelt dat mannen en vrouwen dusdanig verschillen in drinkpatroon dat de relaties tussen gemiddeld konsumptienivo en excesslef" drankgebrulk konsekwent van elkaar verschillen. De vraag of "excesslef drankgebrulk", door aanhangers van het single distribution model meestal gedefiniëerd als gemiddeld 8 of meer glazen per dag (Bruan, e.a., 1975), ongeacht drinkpatroon een goede indikator is voor de mate waarin nadelige gevolgen van drankgebrulk voorkomen, wordt door drie prominente vertegenwoordigers, Popham, Schmidt en de Iint (1976) bevestigend beantwoord.

Het single distribution model laat derhalve twee vragen, die vanult de hier aangehouden optiek relevant zijn, grotendeels onbeantwoord:

- of "verzamelingen" (In de betekenls van geen gemeenschappel1jk soclaal kenmerk) drinkers die overeenkomen in gemiddelde konsumptie per hoofd van de bevolking, echter verschlllen in drinkpatroon, verschillen dan wel overeenkomen in percentages overmatige drinkers, 
- of overmat1g drankgebrulk, gedef1nlëerd in termen van gemiddeld aantal glazen per week, ongeacht drinkpatroon, in dezelfde mate tot nadellge gevolgen van drankgebrulk leldt.

Deze vragen behoren niet tot de probleemstellingen van deze studie. Beantwoording ervan verheldert echter wel de achtergrond van de verwachte relatie tussen statuskenmerken die samenhangen met drinkpatroon en de kans op nadelige gevolgen. Derhalve zal in deze studle de kans aangegrepen worden, ook enlge analyses aan bovengenoemde twee vragen te wljden. In hoofdstuk VIII zal hierop worden ingegaan worden en zullen ook hypothesen worden geformuleerd.

IV. 2. 2. Drinkgeschiedents

In de onderzoeksliteratuur is veel te vinden over 'gewenning", dat w1I zeggen de bij langere duur van drankgebruik op en bepaald nivo optredende tolerantie voor de effekten van alkoholhoudende drank. Eksperlmenteel is aangetoond dat b1f langere duur van alkoholgebrulk steeds grotere doses nodig zlJn on hetzelfde effekt te berelken (Schippers, 1981). Ik neem aan dat deze 'verworven tolerantle' ook blijkt utt het afnemen van de kans op effekten als dronkenschap, blackouts, tremors, naarmate men langere tijd dezelfde (hoge) hoeveelheden alkoholhoudende drank gebrulkt.

Als hypothese zal worden aangehouden:

bij grotere gewenning aan alkoholhoudende drank

leidt drankgebruik, ook na kontrole op konsumptienivo, in mindere mate tot nadetige gevolgen.

IV. 2.3. De soctale situatie

In het vorig hoofdstuk is gesteld dat bif een weinig gestruktureerd dagelijks leven de behoefte aan intensivering van situatierolien groter 1s, ondat daarmee het ontbreken van struktiur en betekenis in het alledaags leven $-\mathrm{z} 1 \mathrm{j}$ het wellicht gebrekkig- geneutrallseerd wordt. Deze redenering wifst er al op dat bif een weinig gestruktureerd dagelijks 
leven sprake is van een vergelljkenderwljs moellijker soclale situatie.

Betekent dit nu ook dat, b1f een overeenkomstig konsumpt1enivo, de kans op nadelige gevolgen van drankgebrulk groter is als er sprake is van en weinig gestruktureerd dagelijks leven?

Afgaande op de mif bekende literatuur, moet dit een open vraag genoemd worden, omdat er noch op theoreties vlak, noch met onderzoeksresultaten uftspraken over gedaan worden.

Toch acht ik het mogelijk dat bij mensen met een weinig gestruktureerd dagelijks leven de kans op nadelige gevolgen van drankgebmuik hoger 1s. Drie redenen wil tk daarvoor noemen.

1. Het is mogelijk dat b1j mensen met een weinig gestruktureend dagelijks leven vaker dan bif anderen incldenteel overmatig drankgebruik voorkomt (eruptief drinkgedrag). Dit drankgebrulk laat zich nlet of nauwelijks registreren met vragen naar de gemiddelde konsumptle per dag of de konsumptie in de afgelopen week, maar verhoogt wel de kans op nadelige gevolgen als dronkenschap, tremoren e.d.

2. Bif mensen met een weinig gestruktureerd dagelljks leven, kan de subjektieve definitie van de effekten van drankgebrulk anders $z 1 j n$. BIf een weinig gestruktureerd dagelifks leven zal de hinderlijkheid van nadelige gevolgen als bv. kater en tremor wellicht nadrukkelijker gevoeld en geregistreerd worden dan in een situatie waar het nakomen van verplichtingen tot op zekere hoogte dwingt de aandacht op andere zaken te richten. Dit kan resulteren in een verschil in melding van nadelige gevolgen van drankgebrulk bif een zelfde konsumptienlvo.

3. Bif de posities met rollen die het dagelijks leven welnfg struktureren kan een onderscheld gemaakt worden tussen posities die gekenmerkt worden door het ontbreken van een door velen in de samenleving normaal geachte roll: werkzoekend, arbeldsongeschikt, geschelden, ouder noolt-gehuwd, en posities die een meer vanzelfsprekende overgang in levensfase markeren: kinderen ult huls, gepenstoneerd, weduwe/weduwnaar.

Uit onderzoek van 0.a. Merens Riedstra (1981) komt naar voren dat het ontbreken van een matschappelifk normaal geachte rol, op zlch een bron van spanningen 1s. Spanningen die, gezien de uitkonsten van Bazuin en Mulder 
(1981), ook kumnen lelden tot een verhoogd gebrulk van slaap- en kalmerende middelen, blj gescheldenen (echter ook verweduwden) en werkzoekenden. ook in het eerder aangehaalde onderzoek van van Oyen en Grosveld(1982) en van Adriaanse e.a. (1981) valt op dat de arbeidsongeschlkten c.q. niet aktleven en werkzoekenden veel vaker slaap- en kalmerende m1ddelen gebrulkten dan de werkenden.

Deze sparningen, eventueel meer speciflek de komblnatie van slaap- of kalmerende middelen met alkohollese drank, kan ertoe lelden dat eenzelfde doses alkoholhoudende drank harder aankomt, 1.c. meer nadelige effekten heeft. Als hypothese wil ik dan ook aanhouden:

bij mensen met een weinig gestmiktureerd dagelijks

leven is, bij een overeenkomstig konsumptienivo,

de kans op nadelige gevolgen van drankgebmik grotex.

Afgezien wordt van een verdergaande hypothese over mogelijke verschillen tussen degenen bij whe een maatschappelijk normaal geachte rol ontbreekt en degenen bif wie de levensfase hun huidige positie bepaalt. B1j de analyse zal, voorzover mogelljk, hier wel op worden ingegaan.

\section{3. Afkeuring van of zorgen over drankgebruik}

IV.3.1. Begripsomschrijving en de relatie van

Afkeuring van en zorgen over drankgebrutk worden amschreven als: aanmerkingen op het drinkgedrag van lemand of op de gevolgen van diens drankgebrulk, dan wel zorgen van de drinker zelf over zi jn drankgebrulk of de gevolgen ervan.

In de meeste studies naar probleendrinken wordt afkeuring van drankgebrufk gezien als één van de problemen waarmee drankgebruik gepaard kan gaan, naast bv. symptomen van drankgebrulk of psychologlese afhankelljkheld (Cahalan, 1976). Hler wordt afkeuring van drankgebrutk gezien als reaktle op ult het drankgebrutk voortvloelende gevolgen, als bv. symptomen en dronkenschap.

De voomaamste reden voor afkeuring van of zorgen over 
drankgebrutk zal zljn de mate warin drankgebrulk gepaard gaat met nadelige gevolgen. Deze nadelige gevolgen Immers $\mathrm{z}$ Ijn een mogelijke bron van overlast voor anderen en kumnen aanlelding zifn voor twijfel bif de drinker zelf of mensen uit zijn amgeving of hij nog in staat is maatschappell $\mathrm{jk}$ belangr1jk geachte verplichtingen (1.c. positierollen) adekwaat na te komen. Toch is er meer te zeggen over de kans dat drankgebruik afgekeurd wordt.

Ook b1f een overeenkomstige mate van schadelifke gevolgen van drankgebrulk, kan er nog verschil z1jn in de kans op afkeuring van drankgebrulk naar gelang:

- het gangbaar drinkpatroon

- de drinkgeschiedenis

- de sociale situatie van de drinkers

IV.3.2. Gangbaar drinkpatroon

Naar gelang gangbaar drinkpatroon, kan er verschil zijn in de mate waarin nadelige gevolgen van drankgebrulk geperclpieërd worden als incldent dan wel als verontrustend teken van excessief drankgebruik. BIJ een gangbaar drinkpatroon, waarbif op weekenddagen 6 of meer glazen per dag worden gedronken, kan 1 of 2 maal per maand dronkenschap nog gezlen worden als een Incident. Immers het grootste aantal keren dat lemand drinkt treden er geen nadelige gevolgen van drankgebrulk op. Bif een drinkpatroon waarbij alleen bif b1jzondere gelegenheden wordt gedronken, stel maximaal vier keer per maand, betekent 2 maal per maand dronken dat de helft van het aantal keren dat lemand drinkt, deze ook dronken 1s. De kans moet groter geacht worden dat anderen of de drinker zelf, dit als teken van onvermogen zlen om met drank om te gaan en derhalve het drankgebrulk afkeuren.

De hypothese is:

in statusgroeperingen waar een drinkpatroon gangbaar

is dat vergelijkenderwijs vaak leidt tot nadelige

gevolgen, is de kans op afkeuring van of zorgen over drankgebruik geringer dan in een statusgroepering waarin drankgebruik minder vaak gepaard gaat met nadelige gevolgen. 


\section{IV.3.3. Drinkgeschiedents}

B1y langere dunur van excesslef drankgebrulk wordt het, naar 1k aanneem, moellifker on nadelige gevolgen van drankgebrulk af te doen als onbelangl $1 \mathrm{jk}$ inc1dent. De kans op afkeuring of zorgen neemt naar $1 \mathrm{k}$ vermoed toe. De onderzoeken waarover 1k. kan beschikken, bevatten geen gegevens over de duur waarmee het drankgebrulk gepaard gaat met nadelige gevolgen. Wel 1s gevraagd hoe lang men het huldig aantaal glazen per dag drinkt.

In de hypothese wordt daarom duur van huldig drankgebrutk -als globale ind1kator voor de perlode waarover drankgebrulk gepaard is gegaan met nadelige gevolgen- als onafhankellyke variabele genoemd.

De hypothese luidt als volgt:

bij overeenkomstige mate van nadelige gevolgen van drankgebruik, zal de kans op afkeuming van drankgebruik grotex zijn naarmate men over een langere periode een bepaald aantal glazen per dag drinkt.

IV. 3.4. Soclale s1tuatie

Het nlet kumnen vervulien van verplichtingen voortvloelend ult positierollen is een sterke reden voor afkeuring van drankgebrutk. Is het nu echter zo, dat als er in mindere mate alledaagse verplichtingen $z 1 \mathrm{jn}-1 . c$. bif een weinig gestmuktureerd dagelijks leven- nadelige gevolgen van drankgebrulk sneller tot kritlek of zorgen leiden?

Er $z 1 \mathrm{fn}$ twee redenen aan te geven an deze vraag bevestigend te beantwoorden.

- als men In mindere mate kan $w 1 j z e n$ op een alledaags handelen waarin men verpllchtingen Jegens anderen nakomt, dan kunnen nadelige gevolgen van drankgebrutk door de sociale ongeving en/of de drinker zelf geperclplëerd worden als een markanter aspekt van de leefstifl dan in het geval dat, ondanks nadelige gevolgen, verplichtingen jegens anderen nog worden nagekomen.

Indfen door het ontbreken van een maatschappel1.jk normaal geachte rol (werkzoekende, arbeidsongeschikte, gescheidene, oudere noolt gehuwde) het dagel1jks leven weinig gestruktu- 
reerd is, kan nog een meer spectfleke reden genoemd worden: - błj het ontbreken van een maatschappel1jk normaal geachte rol, zullen nadelige gevolgen van drankgebrulk sneller geperclplëerd worden als 'oorzaak' van het ontbreken van een maatschappelijk normaal geachte rol. Dit zal sneller krltiek of zorgen over het drankgebrulk uftlokken, dan waar maatschappelifk normaal geachte rollen vervuld worden.

BIf deze laatste redenering moet erop gewezen worden dat bif een aantal van degenen bij wie een maatschappelifk normaal geachte rol ontbreekt, het drankgebruik $\infty \mathrm{k}$ daadwerkell jk kan hebben bijgedragen aan bv. het verlies van werk of partner. Volgens de mlj ter beschllking staande gegevens, kan dit aantal niet hoog worden genoemd. In Limburg geven 8 respondenten op dat hun partner gedrelgd heeft weg te gaan of is weggegaan vanwege drankgebruik, in Rotterdam 10. In Limburg en Rotterdam geven respektlevelijk 4 en 10 respondenten op dat ze vanwege drankgebrulk opgehouden $z 1 \mathrm{jn}$ met werk. Zo de verwachte samenhangen worden gevonden, 11jkt het mij onwaarschijnlijk dat deze klelne aantallen respondenten daarvoor verantwoordelijk zIjn.

Als hypothese wordt aangehouden dat:

bitj overeenkomstige mate van nadelige gevolgen van drankgebruik, is de kans op afkeuring of zorgen hoger ingeval van een weinig gestmiktureerd dagelijks leven. Ik wil wat betreft de hypothese afzlen van nadere speclfikatie aangaande de samenhang tussen het ontbreken van een maatschappelifk normaal geachte rol en de kans op afkeuring of zorgen. Door middel van nadere analyse zal wel gepoogd worden aan te geven of b1j het ontbreken van een maatschap pelljk nomaal geachte rol de in de hypothese genoemde tendens zich sterker voordoet.

In de onderzoeksliteratuur is één summlere aanwljzing te vinden over het verband tussen het ontbreken van normaal geachte rollen en de kans op afkeuring van drankgebruik. Hingson e.a. (1980) vonden dat bij probleemdrinkers die ruwweg overeenkwamen in konsumptientvo en drinkproblemen, echter verschilden wat betreft het erkennen dát ze drinkproblemen hadden (te vergelljken met zorgen over drankgebruik), zich op twee punten van elkaar onderscheidden. Bif de probleemdrinkers die erkenden dat hun drankgebrulk problematles was, was een hoger percentage werkloos en een hoger percentage met kinderen. Geen verschillen vonden deze 
onderzoekers wat betreft beroepsnlvo, al dan niet met partner samenlevend, religle en aantal goede vrlenden.

Het hogere percentage werklozen blj degenen die erkenden drinkproblemen te hebben, komt overeen met mijn hypothese. Zo nlet het hogere percentage met kdnderen. Deze ultkomst kan eraan herinneren dat ook andere dan de hier genoemde faktoren van invloed kumnen zijn op afkeuring van of zorgen over drankgebrulk. Met name als anderen sterk afhankel1,jk zIIn van adekwate uitvoering van een positierol -zoals $\mathrm{k}$ nderen van ouders- kan drankgebruik, gepaard met nadelige gevolgen, wellicht sneller leiden tot kritiek of zorgen. De analyse zal dan cok moeten leren of de geformuleerde hypothese ongewlyzigd is te handhaven.

Samenvatting

Twee probleemstellingen, te weten andere faktoren dan konsumptienivo die van invloed zifn op nadelige gevolgen van drankgebrulk en de faktoren die van invloed zl In op de kans dat drankgebrulk afgekeurd wordt, z1 In in dit hoofdstuk vanuit theoreties perspektief toegellcht.

Nadellge gevolgen van drankgebrutk zifn omschreven als tijdens of na drankgebrulk optredende verschijnselen, die een adekwaat funktioneren van de drinker in enigerle1 opzicht beinvloeden en door de gebrulker of mensen uit zijn leefomgeving gezien worden als gerelateerd aan drankgebrulk. BIf deze amschrlfving is de kanttekening gemaakt dat, voor de verzameling drinkers bif wle de nadelige gevolgen van drankgebrulk beperkt bl1fven tot verschijnselen die niet of zelden door leken herkend worden als gerelateerd aan drankgebrulk, bv. leverclrrose, maagzweer, de ontwlkkelde hypothesen nlet te ver1f1ëren z1.Jn. Afgaande op de 11teratuur moet deze verzameling drinkers vooral bil oudere mannen ult de hogere klasse worden gezocht.

op grond van theoretlese overwegingen werden de volgende hypothesen ontwlkkeld:

Statusgroeperingen die verschizien in drinkpatroon, kunnen verschizien in de mate warain, bij overeenkomstig konsumptienivo, nadelige gevolgen van drankgebruik voorkomen.

Bij grotere gewenning aan alkohothoudende drank aal, ook na kontrole op konsumptienivo, het drankgebruik 
in mindere mate gepaard gaan met nadelige gevolgen. Bij mensen met een weinig gestmktureerd dagelijks Leven is, bij overeenkomstig konsumptienivo, de kans op nadelige gevotgen van drankgebruik groter.

Afkeuring van of zorgen over drankgebruik, de athankel1 jke varlabele in de tweede probleemstelling, is onschreven als aanmerkingen op het drinkgedrag van iemand of op de gevolgen van diens drankgebruik, dan wel zorgen van de drinker zelf over ziJn drankgebrulk.

Aangenomen wordt dat naarmate het drankgebruik gepaard gaat met meer nadelige gevolgen en/of de konsumptie hoger is, de kans op afkeuring van drankgebmulk groter is.

Dok bif kontrole op konsumptientivo en nadelige gevolgen, kumnen echter nog verschillen zljn in de kans op afkeuring of zorgen. De volgende hypothese werden geformuleerd:

In stutusgroeperingen war aen drinkpatroon gangbaar is dat vergelijkenderwijs vaak leidt tot nadezige gevolgen, is de kans op zorgen of afkewring gexinger dan in statusgroeperingen met een gangbaar drinkpatroon dat minder vaak tot nadelige gevolgen leidt. Bij overeenkomstige mate van nadelige gevolger. van drankgebmik, zat de kans op afkeuring van drankgebruik groter zijn naarmate men over een zangere periode het huidig aantal alazen per dag drinkt.

Bij overeenkomstige mate van nadelige gevotgen van drankgebruik, is de kans op afkeuring of zorgen groter bij een weinig gestmktureerd dagelijks leven.

In onderstaand figur zijn de in hoofdstuk II tot en met IV ontwikke lde hyothese weergegever.

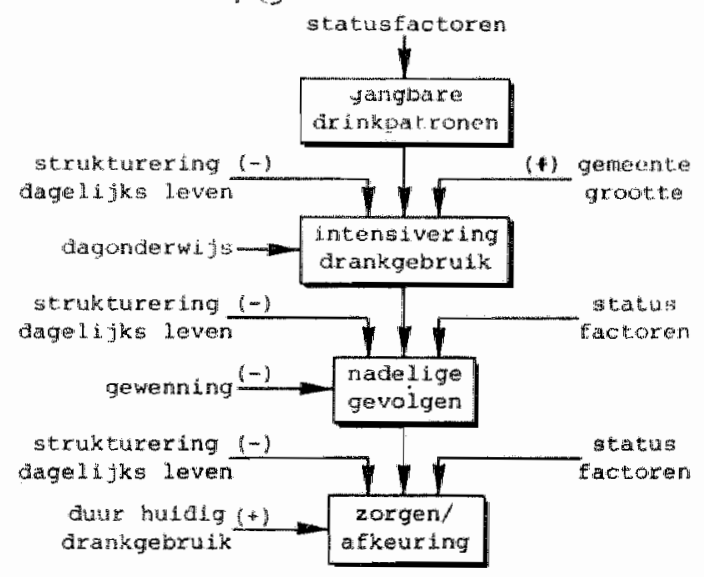


In de hoofdstukken VI, VIII en IX zullen de resultaten aangaande deze hypothesen worden gepresenteerd. Eerst volgt echter een hoofdstuk over de onderzoeken die in deze studie worden gebruikt en wordt de betrouwbaarheid en geldigheld van de gegevens over alkoholkonsumptle besproken. 
DEEL II : ONDERZOEK 
V De gebruikte onderzoeken; betrouwbaarheid

en geldigheid van konsumptiegegevens

Zoals gezegd zullen in deze studie onderzoeksgegevens gebrulkt worden uft Limburg en Rotterdam. Het betreft twee 1dentleke survey-onderzoeken naar probleemdrinken, ultgevoerd door respektlevel1.jk de Rifksuniversiteit Llmburg en de $G G$ en GD in Rotterdam.

Het veldwerk is ultgevoerd elnd 1980 en begin 1981. Over belde onderzoeken is uitvoerig gerapporteerd. (Garretsen, 1982; Kn1bbe, 1982, Garretsen, Kn1bbe, 1983; Garretsen, 1983)

Bif deze rapportage is ook de onderzoeksopzet, steekproeftrekking, representativiteit en non-respons verantwoord. Hier zullen deze onderwerpen derhalve slechts kort behandeld worden.

U1tvoeriger zal ingegaan worden op de betrouwbaarheld en geldigheld van de gegevens over alkoholkonsumptle. Hoewel het hier niet gaat on de prevalentie- van probleendrinkers, is het vraagstuk van de betrouwbaarheid en geldigheld van gegevens over alkoholkonsumptle ook van belang voor de geldigheld van samenhangen tussen alkoholkonsumptle en andere faktoren.

V.1. Steekproeven en veldwerk

Steekproef

In LImburg en Rotterdam zifn de bevolkingsregisters gebrulkt on naar geslacht, leeft1Jd en in Limburg ook naar regio en gemeentegrootte, gestratificeerde steekproeven te trekken.

De in Rotterdam en Limburg geselekteerde aantallen potentiele respondenten werden tamelljk hoog genomen in verband met de verwachte non-respons van $\pm 25 \%$ en de wens in de geinterviewde populatie een voldoeñde aantal probleemdrinkers aan te treffen.

In Rotterdam, waar het bevolkingsregister is geautonat1seerd, kon vrij eenvoudis een gestratificeerde a-selekte steekproef van 3040 respondenten in de leeft1ja van 16 tot 70 Jaar worden getrokken. 
In Limburg is de steekproeftrekking van in totaal 2670 potent1ele respondenten lets gekompliceerder geweest. Begonnen werd met een selektie van gemeenten en wel op de volgende wiflze:

- alle gemeenten met meer dan 30.000 inwoners werden b1 $J$ het onderzoek betrokken;

- van de geneenten met inwonersaantallen tussen de 5.000 en 30.000 Inwoners werd op wlllekeurlge wifze ledere tweede gemeente genomen. (C.B.S.-1ndel1ng, kat. B2, B3, $\mathrm{C} 1$ en $\mathrm{C} 2$, met uitzondering van Venray en Weert, belden gerneenten met meer dan 20.000 inwoners);

- van de semeenten met minder dan 5.000 inwoners werd op w11lekeurige w1Jze ledere derde geneente geselekteerd. (C. B. S. -indeling, kat. A1, A2, A3, A4 en B1).

De reden voor deze selektle van gemeenten was de wens een zekere konsentratle van adressen van respondenten in kle1nere gemeenten te bewerkstelligen en zodoende relstijd en -kosten te besparen bif de uitwoering van het veldwerk.

De aldus geselekteerde gemeenten werden aangeschreven. Alle gemeenten bleken bereld mee te werken. Gezlen de wens bij de steekproeftrekking in LImburg op geslacht, leeft1jd, reglo en urbanisatlegraad te kontroleren, zljn bif de geselekteerde gemeenten mulmschoots meer adressen aangevraagd dan de geplande 2670 potentlèle respondenten. Zodoende was het namel1jk mogel1jk binnen het bestand verkregen adressen op a-selekte wijze een naar geslacht, leeft1 jd, urbanisat1egraad en regio gestratificeerde steekproef te trekken van exakt 2670 potentlèle respondenten.

Wat betreft de trekkingsmethode, die wlj de gemeenten gevraagd hebben te volgen, hebben wilj ons georlënteerd op de b1j het C.B.S. gebrulkel1 Jke 'Ilneaalmethode'. Deze methode bestaat hlerult, dat de lengte van het kaartbestand van de gemeente gedeeld wordt door het aantal respondenten dat door ons werd aangevraagd, een procedure dle de zogeheten "stapgrootte! oplevert. De gemeenten werd gevraagd na de stapgrootte nog drle kaarten door te tellen en de daarop vermelde persoon als respondent op te geven. Het doortellen na stapgrootte was nodig om personen met kaarten die dikker waren andat ze veel gellcht waren ult het bestand-bv. vaak verhuisd, veel kinderen- niet een grotere kans te geven in de steekproef te komen. De gemeenten leverden ons de respondenten aan op 11jsten warop naam, adres, geboortedatum en geslacht vermeld stonden. 
Ultwoering veldwerk

Voor de uttwoering van het veldwerk is zowel in Limburg als Rotterdam gebrulk gemaakt van de diensten van de Nederlandse Stichting voor Statistiek.

Deze stichting beschikt over getrainde interviewers, waarbif voor het veldwerk in Limburg als voorwaarde werd gesteld, dat de Interviewers één van de Limburgse dialekten beheersten. Deze voorwaarden werd ingegeven door de wens misverstanden tussen interviewer en respondent te vermijden en een zo goed mogelifk kontakt tussen hen te bewerkstelligen.

De vragenlijst waarmee in Rotterdam en Limburg werd gewerkt, was van tevoren getest bif 'normale' drinkers en bif drinkers die bif het C.A.D. bekend waren als probleendrinkers. De interviewers $\mathrm{zl} \mathrm{fn}$ via een groepsgewlyze instruktie vertrouwd gemaakt met de doelstellingen van het onderzoek en geinstmueerd over het afnemen van het interview. Tevens namen de interviewers elkaar een proefinterview af dat vervolgens met de onderzoeksleiders in Limburg en Rotterdam werd besproken.

Tot de instrukties aan de interviewers behoorde ook de opdracht die personen die bleken te $\mathrm{z} 1 \mathrm{Jn}$ opgenomen in een algemeen of psychlatries zlekenhuls, dan wel wonachtig waren In opvangtehuizen, kostscholen, intermaten e.d., niet tot de respondenten te rekenen. Dit gold ook voor personen die niet (voldoende) de Nederlandse taal beheersten.

Belde kategorleën zljn uitgesloten ondat de vragenlifst niet op hun situatie berekend was. Voor degenen die verbleven in een instelling kwam daarbif dat moellijkheiden konden optreden om toesteming te krljgen voor een interview.

op de non-respons zal in paragraaf V. 3. gedetallleerd ingegaan worden.

De doelstelling dat de geinterviewde steekproef een afsplegeling is van de bevolking kan, voorzover het de soclale kennerken betreft waarop bij de steekproeftrekking is gekontroleerd, gerealiseerd worden geacht.

De grootste afwljking in Limburg betrof een oververtegenwoordiging van 2.5\% vrouwen in de leeftijdskategorle 55-70 jaar bij de respondenten vergeleken met bevolkingsgegevens van het C.B.S.

In Rotterdam is de grootste afwijking dat de steekproef 3. 3.\% meer vrouwen van 20-29 Jaar telde dan verwacht kon 
worden op grond van de bevolkdingsgegevens van de gemeente Rotterdam.

Voor Llmburg kon worden vastgesteld, dat ook voor een kenmerk waarop niet bif steekproeftrekking is gekontroleerd -burger 11jke staat- de afwlJking van de gelntervlewde populatle met de gehele bevolking niet groter is dan $4 \%$.

V.2. Betrouwbaarheld en geldigheld van gegevens over alkoholkonsumptie

In het Limburgse en sterker nog in het Rotterdams onderzoek is aandacht gegeven aan de betrouwbaarheid en geldigheid van gegevens over alkoholkonsumptle. De omvang van dit probleem kan afgelezen worden ult onderstaande tabel (overgenomen ult van Reek e.a., 1983).

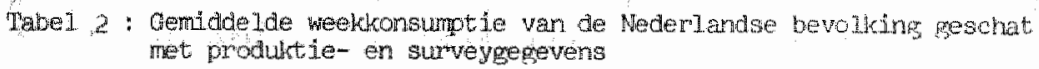

Feektonsumptie

ondersmateing

$\begin{array}{lccc} & \text { proa.cigers } & \text { survey-gegevens } \\ 1958 & 5.1 \mathrm{gg.} & 2.5 \mathrm{gl} . & 51 \% \\ 1970 & 12.8 \mathrm{gg} . & 6.2 \mathrm{gl} . & 52 \% \\ 1981 & 17.1 \mathrm{gl} . & 7.5 \mathrm{gl} . & 56 \%\end{array}$

De schattingen van konsumptle op grond van surveygegevens z1Jn konstant onstreeks de helft lager dan schattingen van de konsumptle op grond van de betrouwbaarder produktlegegevens. Deze onderschatting is derhalve een niet gering probleern.

Wellswaar z1.jn er beperkingen aan de vergel1jkbaarheld van surveygegevens en produktlecljfers. De schatting volgens produktlegegevens wordt berekend voor de bevolking van 14 Jaar en ouder, en er is geen korrektle mogellyk voor bultenlanders die in Nederland drinken, noch voor nederlanders die In het bultenland drinken. Deze beperkingen tasten echter de omvang van het probleem nauwel1jks aan. De voornaamste bronnen voor deze onderschatting van alkoholkonsumptle moeten gezocht worden in de non-respons en in onderrapportage bij de geInterviewde steekproef. Deze bronnen van 
onderschatting zullen in de volgende paragrafen worden behandeld.

\section{3. Non-respons als bron van onderschatting}

In tabel $3 \mathrm{z} 1 \mathrm{jn}$ voor Limburg en Rotterdam de percentages non-respons in onderschelden geslachts- en leeftljdsgroepen weergegeven.

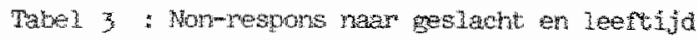

\begin{tabular}{|c|c|c|c|c|c|c|}
\hline \multirow[b]{2}{*}{ leartiga } & \multicolumn{2}{|c|}{ Master } & \multicolumn{2}{|c|}{ WROA FIDN } & \multirow{2}{*}{ 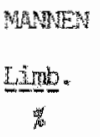 } & \multirow{2}{*}{$\begin{array}{l}\text { EN WOUWEN } \\
\frac{\text { R dam }}{\pi}\end{array}$} \\
\hline & 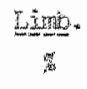 & 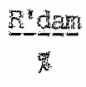 & 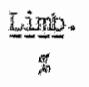 & $\frac{x^{2} \mathrm{dam}}{{ }^{2}}$ & & \\
\hline $16-69$ aar & 26.1 & 3 & 22.9 & 25.6 & 24.1 & 28.3 \\
\hline $16-35 \mathrm{jag}$ & 31.4 & 32.9 & 26.3 & 28.0 & 28.8 & 30.3 \\
\hline $36-69$ saat & 22. & 29.9 & 19.3 & 24.4 & 20.7 & 27.1 \\
\hline
\end{tabular}

Een eerste inzlcht in de bijdrage van de non-respons aan de onderschatting van alkoholkonsumptie kan verkregen worden door na te gaan of de non-respons hoger is in subpopulaties die gekemmerkt worden door een vergellfkenderwl js hoog konsumptientvo. Er wordt namelijk aangenomen dat in de non-respons het percentage zware drinkers hoger is dan in de respons (Pemanen, 1974).

In Limburg en Rotterdam is het konsumptienfvo van mannen (respektlevel1fk 16.2 en 12.9 glazen per week) hoger dan dat van vrouwen (respektlevelijk 6.2 en 5.5 glazen per week) en is ook de non-respons blf mannen hoger.

In Limburg en, in minder sterke mate, in Rotterdam is de non-respons in de Jongere leeftijdsgroepen hoger dan in de oudere leef't jdsgroepen. In Limburg kenmerken de jongere leeft 1 Jdsgroepen zlch door een hoger geniddeld konsumptlenivo. Mogelijk zou bif en gelljke non-respons bif jongeren en ouderen in Limburg, het gevonden verschil in konsumptle nog groter z1jn.

In Rotterdam acht $1 \mathrm{k}$ de verschillen tussen leeftijdskategorleën In non-respons ( $3 \%$ bif mannen en $3.6 \%$ bif vrouwen) te klein om uitspraken aan te verbinden. Konkluderend kan ge- 
steld worden dat er aanwljzingen zijn dat in Limburg en Rotterdam de versch11len in konsumptle tussen mannen en vrouwen. groter $z 1 j$ in dan ult de survey-gegevens blifkt. In Limburg z1.jn mogel1jk de verschillen in konsumptie tussen Jongere en oudere mannen en vrouwen groter dan ult de survey-gegevens biljkt.

Zoals gezegd, wordt aangenomen dat zware drinkers eerder genelgd $\mathrm{zlj}$ n een interview over drankgebrulk te welgeren dan wel moell1jker te berelken z1jn voor een interview (Pemanen 1974).

Garretsen (1983) is nagegaan of onder de non-respons van het Rotterdams onderzoek probleemdrinkers zaten die bekend waren bif de Bouman-Stichting in Rotterdam (C. A. D. en twee alkoholk.1nieken).

H1 j kwam tot de konklusle dat op grond van dit deelonderzoek nfet gesteld kan worden dat de non-respons onder probleemdrinkers hoger is dan onder nlet-probleemdrinkers'. In het Limburgse en Rotterdamse onderzoek is het gelukt bif een deel van de non-respons alsnog enkele gegevens over alkoholkonsumptle te verkrilgen, voomamell jk door telefonlese ondervraging.

Verrassend genoeg bleek bil deze respondenten een hoger percentage dan in de ultgebreld gelnterviewde steekproef te verklaren dat vragen over drankgebmuk op hen nlet van toepassing waren (Knibbe, 1982, Garretsen, 1983). Zekerheld, dat dit ook allen geheelonthouders zifn volgens de omschrifving die hlervoor in belde onderzoeken is aangehouden, is er niet. Desalniettemin bl1jft het een opmerkel1jke ultkomst. Hier is echter relevanter de ultkomst in Limburg, echter niet in Rotterdan, dat bif de drinkers onder de non-respons d1e alsnog gegevens over alkoholkonsumptle verstrekten, het percentage dat de afgelopen zaterdag 6 of meer glazen hadden gedronken hoger was dan b1j de drinkers in de ultgebreld. geIntervlewde steekproef.

Er is derhalve voor Limburg met enige zekerheld te bevestIgen dat in de non-respons het percentage overmatige drinkers hoger is dan in de geInterviewde steekproef. 
V. 4. Onderrapportage

Van onderrapportage is sprake als respondenten, al dan niet opzettelijk, een lagere alkoholkonsumptle opgeven dan ze in werkelljkheld hebben gedronken. Eerst zal de onopzettelljke onderrapportage worden besproken.

V.4.1. Onopzettelijke onderrapportage

De belangrljkste bronnen van onopzettelljke onderrapportage zifn:

- vergeetachtigheld van de respondent

- het nlet systematies navragen van konsumptie op hoogt1jdagen als verjaardagen, kerstdagen, karnaval, e.d.

- het noteren van de konsumptie in standaardglazen alkohol.

Beginnen we met vergeetachtigheld, dan kan vermoed worden dat naarmate de konsumptie langer geleden is, de opgaven minder betrouwbaar worden. D1t wordt bevestigd door Ph1lipsen e. a. (1983). Z1j berekenen door "een fictieve Nederlander* (te) creeëren, voor wle -voorzover het om de doordeweekse dagen gaat- zijn geheugen niet verder hoeft terug te gaan dan twee dagen geleden", dat de gemiddelde Nederlander twee glazen meer per week drinkt dan bij schattingen van weekkonsumptie waarin cok opgaven over konsumptle van meer dan twee dagen geleden $\mathrm{zl}$ fn opgenomen. Uitgaande van deze fictleve nederlander zou de onderschatting van konsumptle in 1981 niet 56\% maar 44\% zijn geweest.

* De "fictleve Nederlander" werd gekonstrueerd door per doordeweekse dag (maandag $t / m$ donderdag) de gemiddelde konsumptle te berekenen ultsluftend afgaande op de antwoorden van respondenten voor wle de betreffende dag "gisteren" of "eergisteren" was. De zo berekende schatting van de gemiddelde konsumptle op die dag werd geldig geacht voor alle drinkers in de steekproef. 
U1t een vergelljking van dagboek- en vragenlijstgegevens over drankgebrulk blljkt nog duldelljker dat de ongewlide onderrapportage aanzlenl1jk is. Polkalanen en Kărkkainen (1983) konstateren dat bif 49 mannelfjke vrljwllligers de gem1ddelde konsumptie volgens dagboekopgaven ( 6 aaneengesloten weken bestrifkend) rufm 1.6 maal hoger is dan volgens vragenlifst opgaven. Deze onderzoekers melden dat de verschillen in konsumptie volgens dagboek- en vragenlijstmethode niet afhankelifk zljn van leeftijd, konsumptienivo, frekwentle van drankgebrulk en frekwentle van dronkenschap. De konklusle van belde onderzoekers is relevant genoeg om geclteerd te worden: '.... the ranking of subjects according to questionnalre data is not blased in a group motivated to give accurate answers'.

Gezlen het voorgaande, is het begrijpelijk dat in surveyonderzoek veelal naar recent drankgebrulk wordt gevraagd, on aan de hand daarvan tot schattingen over jaarlijks gebruik te komen. Noodzakelljkerwljs wordt hierdoor echter voorbilgegaan aan het drankgebrulk bif bijzondere gelegenheden -feestjes, recepties- en op kollektleve feestdagen, bv. de kerstdagen en oud en Nieuw. Echter Juist op die dagen wordt er door meer mensen gedronken en vaak een groter aantal glazen dan in een "gewone" week.

Derhalve ligt hier ook een bron van onderrapportage.

De laatste bron van onopzettel1jke onderrapportage 1 s dat de opgaven van respondenten over konsumptie vrijwel altijd in standaardglazen wordt genoteerd. Het grote voordeel hiervan is dat door deze methode de konsumptie van verschillende soorten drank - Jenever, bler, wi In e.d.- b1j elkaar opgeteld kan worden omdat het aantal cl. pure alkohol per standaardglas voor deze verschlllende soorten drank bif benadering gelifk 1s. Aangenomen mag echter worden dat met name bif drankgebrulk in hulselifke situatles, de glazen wel eens voller geschonken worden dan standaard is. Wilson (1981) heeft bly een representatieve steekproef van de bevolking van Engeland en Wales, de respondenten die sterk-alkohollese drank gebmulkten gevraagd ".... to pour an equivalent of water into their own glass and this was measured by interviewers using small flasks". Het glas thulsgeschonken sterk alkohollese drank bleek gemiddeld anderhalf keer zo veel te bevatten als en standaardglas sterk-alkoholiese drank. Derhalve een ongewilde onderraportage van $33 \%$ bij thulsgeschon- 
ken sterk alkohollese drank. Tk neem aan dat bil andere soorten drank de glazen thuis ook wel eens voller geschonken worden dan standaard is.

Gezlen het feit dat in Limburg 7 van de 10 keren en in Rotterdam 8 van de 10 keer thuls wordt gedronken, is het waarschijnl1jk dat het en aanzlenl1jk deel van de onderschatmting in alkoholkonsumptle betreft.

Samenvattend kan gezegd worden dat onopzettelifke onderrapportage verantwoordeli $\$ \mathrm{k}$ is voor mlnimaal $12 \%$ onderschatting van alkoholkonsumptie, zeer waarschifnlifk echter meer. Ongewllde onderrapportage is een bron van onderschatting die waarschljnlljk niet sterk zal verschlllen voor verschlliende soclale groeperingen. Derhalve zal deze bron van onderschatting niet of niet sterk de geldigheld van gevonden verbanden tussen alkoholkonsumptie en soclale varlabelen aantasten.

\section{V.4.2. Opzettel1jke onderrapportage}

Garretsen (1983) rapporteert uitvoerlg over twee methoden ter detektie van onderrapportage door respondenten. Eén methode hield in dat voor alle probleemdrinkers en 300 willekeur 18 gekozen respondenten uit het Rotterdams onderzoek nagegaan werd of ze bekend waren bif het C.A.D. In Rotterdam of b1j twee alkohol-klinieken in Rotterdam. Het bleek dat totaal 9 respondenten, waarvan v1jf probleemdrinkers, ook bekend waren bij één van bovengenoemde instellingen. Door toepassing van een statistiese bewerking komt Garretsen tot de konklusie dat "als men de vragenlifst zou voorleggen aan Boumancliënten (d.w.z. C.A.D. of één van de twee alkoholkl inieken) verwacht kan worden dat zeer waarschf fnlljk meer dan 53\% van hen als niet-probleemdrinker zou skoren".

Deze konklusie zegt veel over de sensitivitelt van kriterla voor probleemdrinken zoals dle in survey-technjeken worden gehanteerd. De konklusie ten aanzien van onderschatting is minder dramaties. De kans dat probleemdrlnkers bekend bij instellingen in de steekproef zitten en vervolgens door onderrapportage bljdragen aan onderschatting is bijzonder kleln. In Limburg bijvoorbeeld zijn naar schatting maximaal 2000 Limburgers in 1980 geholpen vanwege alkoholproblemen bly het C.A.D., de G.G.Z. of in een algemeen of psychlatrles 
zlekenhuls (Knibbe, 1982). Op een populatie van omstreeks 750.000 mensen en een steekproef van 2670 mensen zouden anstreeks 7 van deze probleemdrinkers tot de potentiele respondenten behoren. De ultkonst van Garretsen breder interpreterend, kan wel gesteld worden dat probleemdrinkers in het algemeen sterker geneigd zullen zijn tot opzettelijke onderrapportage dan niet-probleendrinkers.

De tweede methode die Garretsen toepast is het interviewen van de partners van 395 willekeurlg gekozen gehuwde of samenwonende respondenten over het drinkgedrag van de respondent.

On de informatie die de partner geeft over het drinkgedrag van de respondent te interpreteren, houdt Garretsen als vooronderstelling aan dat als de partner opgeeft dat de respondent meer drinkt of meer drinkproblemen heeft dan de repondent zelf, de partner de betrouwbaarste bron 1s. In het ongekeerde geval echter - de respondent meldt zelf meer te drinken en/of meer problemen vanwege drinken te hebben dan de partner opgeeft- wordt de respondent zelf als de betrouwbaarste bron aangehouden.

Gegeven deze vooronderstellingen kumnen de volgende konklusles worden getrokken:

- rutm 7\% meer mannen en 2\% meer vrouwen drinkt dagel1jks alkoholhoudende drank als ook afgegaan wordt op antwoorden van de partner.

- 1.1 maal zoveel mannen en 4.5 maal zoveel vrouwen drinkt minstens 1 maal per week zes of meer glazen per keer als ook afgegaan wordt op informatie van de partner hierover. Vrouwen verzw1 Jgen derhalve vaker dan mannen dat ze 6 of meer glazen op een dag hebben gedronken.

- door vrouwen wordt ook vaker dan door mannen verzwegen dat er problemen met de ongeving zijn vanwege drankgebrulk

- onkerkel1jken verzw1jgen vaker dan andere drinkers dat ze dagelijks drinken dan wel 3 maal per week of vaker 6 of meer glazen drinken.

- er zlJn geen relevante verschilien in onderrapportage natr opleidingsnivo, beroepsntvo en leeftijd.

Het beeld dat ult deze bevindingen voortkornt samenvattend, kan gesteld worden dat naar alle waarschljnlifkheld de onderrapportage van het veel per keer drinken groter bly vrou- 
wen is dan bij mannen en bif onkerkelijken groter dan bif degenen die zich tot een kerk rekenen. Bif mannen is, vergeleken met vrouwen, de onderrapportage van bet dagel1 fks drinken hoger.

\section{V.5. Konklusie}

Gezien de omvang van onderschatting van alkoholkonsumptie met survey-gegevens, is het opmerkelijk dat er zo weinig onderzoek naar is gedaan.

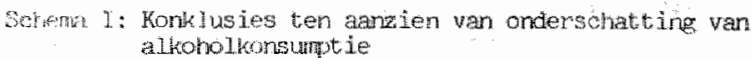

brot var onderschating

morm respons

oregerinde rovportage

bewuste anderrappontage

(1) ronklusies t. a. vi socianil-denografiese groepen

* verschil in konsumptie tussen mannen en vouwer groter dan blijkt ult surwey-gegevens. *verschil ir konsumptie tussen jongeren en oudemen moter (alleen Limburg)

* warachijnlijk niet sterk verschillend voot ondersoheiden subpopulaties

* groter bij vrouwen dan marrien

groter bij onkerkelijken dan kerke 1 jker * geen versohil narar leertijd, opheiding en sociale klasise

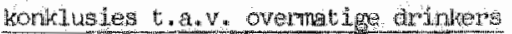

percentage overnatige arinters horer bij non-respons dad bis geinterwiewde populatie

(aideen woon Hiburg gevorich)

*niet bekena

"groter bij plobenderinker 
geldigheld van gegevens over alkoholkonsumptie en verbanden tussen alkoholkonsumptie en andere variabelen aangegeven kunnen worden. In bovenstaand schema is -met terzljdestelling van vele nuances- weergegeven welke konklusies getrokken kunnen worden.

Vr1f zeker is dat overmatige drinkers zowel via non-respons ais v1a onderrapportage sterker bljdragen aan de onderschatting van alkoholkonsumptie dan andere drinkers. Dok Pernanen (1974) en Celentano en Mc.Queen (1978, a,b) komen tot deze konklusie. In het kader van deze studie is daarb1 $\mathrm{J}$ vooral van belang of deze onderschatting door overmatige drinkers dezelfde is in de sociale groeperingen die in dit onderzoek zifn opgenomen. Het onderzoeksmateriaal laat slechts konklusies toe ten aanzlen van geslacht, leeftijd, ople1ding, soclale klasse en godsdienst.

De onderzoeksresultaten van Garretsen geven het sterke vermoeden dat het veel per keer drinken sterker door vrouwen wordt ondergerapporteerd dan door mannen. Tevens dat bif de onkerkelijken het 6 of meer glazen per keer drinken vaker voorkomt dan uit survey-gegevens blijkt.

De sterke onderrapportage bif vrouwen van het veel per keer drinken is waarsch $f$ fnlijk ten dele te wIjten aan sterkere soclale afkeuring van dit drinkgedrag bif vrouwen.

In de analyse kan tot op grote hoogte rekening gehouden worden met een mogelljk versch1l in de mate van onderrapportage bif mannen en vrouwen, door de analyse gescheiden ult te voeren. Dit is niet mogelijk wat betreft kerkelijken en onkerkelljken. Algemeen gesproken kan gesteld worden dat de verschillen in konsumptle tussen kerkelljken en onkerkelijken waarschijnlijk groter zifn dan ult survey-gegevens blijkt. Dit geldt wat betreft Limburg ook voor het versch1l In konsumptle tussen mannen jonger en ouder dan 35 jaar. Hoewel het prettig is te kunnen melden dat er in Rotterdam geen relevante versch1llen in onderrapportage gevonden werden naar leeft1jd, oplelding en soclale klasse, is het voorbarlg op grond daarvan te konkluderen dat deze verschillen niet bestaan. Ten aanzlen van deze en andere faktoren geldt in relatie tot alkoholkonsumptie dat verbanden, gezien de onderschatting, alt1 jd met de nodige voorzlchtigheld geinterpreteerd moeten worden. 
VI Drinkpatronen en verschillen tussen

statusgroeperingen

VT.1. Inleiding

In hoofdstuk II is gesteld dat het drinkgedrag in een populatie -ondanks het ontbreken van expliclete gedragsnormen -door een zekere unfformitelt wordt gekenmerkt.

Vanult twee gezichtshoeken kan de verwachting dat het drinkgedrag in een samenleving door een zekere uniformitelt wordt gekenmerkt, worden toegelicht:

- Vanult de samenleving bezien is het van groot belang dat het Individu -hoewel in zijn drinkgedrag nlet ingeperkt door expliciete normen- toch op een soclaal akseptabele wijze van de vrijheid om te drinken gebrulk maakt. Drinkpatronen als kollektlef gedragselement hebben als funktie dat het drinkgedrag als soclaal akseptabel gedrag herkend kan worden.

Met opzet is gekozen voor de formulering 'sociaal akseptabel', ondat drinkpatronen niet in de eerste plaats gezien moeten worden als een manier om schadelijke gevolgen van drankgebruik te voorkomen. Een beter perspektief om drinkpatronen te begrijpen is uit te gaan van de struktureel en kultureel verankerde ambivalentle rond drankgebrulk. Gangbare drinkpatronen maken het mogelifk - . a. door de massaliteit waarmee het betreffende gedrag voorkomt- de vraag naar de schadelijkheld van het betreffende gedrag goeddeels te negeren.

- Vanuit het individu bezien is, juist bif een gedragselement ten aanzlen waarvan expliclete gedragsnomen ontbreken en waarover amblvalentle bestaat, navolging van anderen een voor de hand liggende manier om deze gedragsmogel1jkheld op een akseptabele en betekenisvolle wijze in het leefpatroon op te nemen.

De serste hypothese die in dit hoofdstuk getoetst zal worden

is tan ook:

de wscheidenheid aan drinkgedrag van individuen

laal aich samenvatten in enkele gangbare drink-

patroner. 
De tweede hypothese betreft de wljze warop deze drinkpatronen in de bevolking gespreld zifn.

op zich behoeven de soclale verwachtingen ten aanzien van het Individuele drinkgedrag nlet verder te gaan dan de verpllchting het drankgebmulk in te rlchten volgens één van de gangbare drinkpatronen. Evenwel, voor bepaalde groeperıngen kunnen elders gangbare drinkpatronen niet geschikt of passend geacht worden, een oordeel van anderen waaraan men $\mathrm{z} 1 \mathrm{ch}$ mogel1jkerwljs in de betreffende groepering moell1.jk kan onttrekken. Dok kumnen in een groepering uitgesproken opvattingen heerssen welk drinkpatroon het meest passend is voor mensen van deze soclale groepering. Deze positleve en negat1eve verwachtingen omtrent drinkpatroon zifn geplaatst in het kader van de statusrol. Van de statusrol is gezegd dat het een brede oriëntatie geeft op het soclale leven en daarmee een relevante ordening van gedragsmogelljkheden bledt in een grote verscheldenheld aan sltuatles. Dok drankgebruik valt onder deze ordening van gedragsmogel1 Jkheden en, afhankelifk van blinen en/of bulten een statusgroeperling aanwez1ge opvattingen over gewenst drinkpatroon $z 1 \mathrm{Jn}$ er verschiliten in gangbaar drinkpatroon tussen statusgroeperingen te verwachten.

Op grond van de bevinding dat in verschlllende onderzoeken de statuskemerken geslacht, leeft1 jd, soclale klasse en godsdlenst naar voren komen als kenmerken dle met meerdere aspekten van arankgebmulk samenhangen, is als hypothese geformuleerd:

Qr ain versonitlen in gangbar drinkpatroon tussen statusgroepemingen, gedefiniëend doon ëen of meer van de statukenmerken geslacht, leeftijd, sociale klasse en godsdienst.

In de derde paragraaf van dit hoofdstuk zal nagegaan worden of deze hypothese verworpen dient te worden. 
VI. 2. Drinkpatronen

VI. 2.1. Opzet van de analyse

Het begrip drinkpatroon is eerder anschreven als een spec1fleke samenhang tussen verschillende aspekten van drinkgedrag.

De aspekten die hier gebrutkt worden voor de operationele definitie van drinkpatronen zifn:

- frekwentie van drankgebrutk

- konsumptle op doordeweekse dagen (maandag $t / m$ vrljdag)

- konsumptie op weekenddagen (zaterdag en zondag)

- verhouding tussen bultenshuls drinken en in hulselijk verband (In elgen huis of bif famille, kennissen e.d.) drinken.

Een vierdemensionele tabel, hier niet geproduceerd, is gekonstrueerd met de Limburgse en Rotterdamse gegevens waarin deze aspekten van drinkgedrag tegen elkaar zifn ultgezet.

Bif de formulering van drınkpatronen heb $1 \mathrm{k}$ me sterker laten leiden door de wens de drInkpatronen duIdelijk van elkaar te onderscheiden dan door de wens ledere drinker één bepaald drinkpatroon toe te schrijven. Inspektie van deze tabellen leldde tot de formulering van vler drinkpatronen die in de volgende subparagraaf beschreven zullen worden.

VI. 2.2. Beschrijving van drinkpatronen

In schema II is aangegeven hoe de verschillende drinkpatronen zijn gedefiniëerd. Tevens zijn in tabel. 4 voor een reeks aspekten van drinkgedras de gemiddelde waarden aangegeven. In biflage I, tabel $2 \mathrm{zl} f \mathrm{n}$ de t-waarden voor verschillen in drinkgedrag bif de onderschelden drinkpatronen weergegeven. 


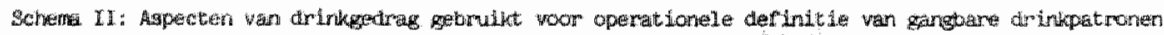

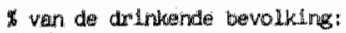

limburing:

Rot tendem:

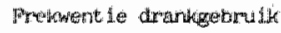

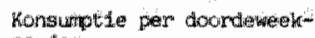
ge dats

Kon un tie per wekerdats.

Vertrouding thuis/but tenshulig dristiken

\begin{tabular}{|c|c|}
\hline $\begin{array}{l}\text { Imelden- } \\
\text { tae ma- } \\
\text { the drin- } \\
\text { ken }\end{array}$ & 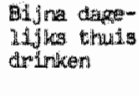 \\
\hline
\end{tabular}

\section{1}

$19 x$

20 keer per meara of vaker

\section{8 keer per} ma:and

minter an

3 gliasen

minaler dan 3 glazen

$*$ meer dan

1 ias

mere dan

1 glat

$2 / 3$ of meer van het drarkgebmilk chuis.

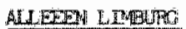

Perlodion veel

drinken

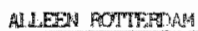

Hentrorm

derisen

\begin{tabular}{|c|}
\hline $\begin{array}{c}20 \% \\
x\end{array}$ \\
\hline 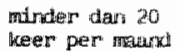 \\
\hline- \\
\hline $\begin{array}{l}3 \text { glazen of } \\
\text { meer }\end{array}$ \\
\hline . \\
\hline
\end{tabular}

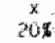

tusiand the 6 wim 20 kear per nand

Thiner dari

3 glazen

miningr dan

3 glasen

- nilet probijht b13 operationele derinitie

Het blijkt dat twee drinkpatronen, benoemd als incidenteel matig drankgebrulk en bljna dagelijks thuls drinken in vrijwel gel1jke mate b1y drinkers in Rotterdam en Limburg voorkomen.

Van de andere twee drinkpatronen 18 er één -benoend als perlodiek veel drinken- alleen in Limburg gevonden. In Rotterdam voldoet slechts $8 \%$ van de drinkers aan de kriterla voor dit arınkpatroon. B1j deze 8\% komt café bezoek ook minder vaak voor dan bij degenen in Limburg die perlodiek veel drinken. Het geringe aantal Rotterdamse drinkers dat aan de kriterla voor dit drinkpatroon voldoet, laat niet toe het in Rotterdam tot de "gangbare" drinkpatronen te rekenen. Het vierde drinkpatroon, 'mengvorm' genoend, is alleen in Rotterdam gevonden. Vergeleken met andere drinkpatronen, is het een minder karakteristieke wijze on drankgebruik in het leefpatroon op te nemen. Daarover zal straks meer gezegd worden.

In totaal blijkt in Limburg aan $73 \%$, in Rotterdam aan $78 \%$ 
van de drinkers één van de bovengenoemde drinkpatronen toegeschreven te kunnen worden. De hypothese dat de verscheldenheld aan individueel drinkgedrag samengevat kan worden in enkele gangbare drinkpatronen, kan bevestigd worden geacht.

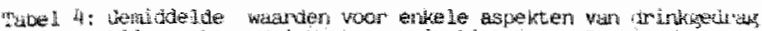

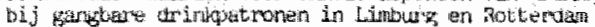

\begin{tabular}{|c|c|c|c|c|c|c|}
\hline & $\begin{array}{l}\text { INCIID } \\
\text { SAT?TO }\end{array}$ & TETH & $\begin{array}{l}\text { BITHA } \\
\text { THYTS }\end{array}$ & $\begin{array}{l}\text { HORLINKS } \\
\text { RIMNGEN }\end{array}$ & 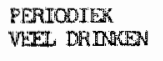 & MONOWOA \\
\hline$\because$ & Line. & Rldam & Limo. & B'dann & Donet. & $\underline{n^{+} d \operatorname{deg}}$ \\
\hline 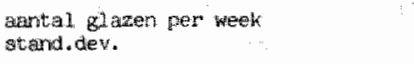 & $\begin{array}{r}2.10 \\
2.9\end{array}$ & $\begin{array}{l}1.6 \\
2.4\end{array}$ & $\begin{array}{l}22 \cdot 0 \\
33 \cdot 9\end{array}$ & $\begin{array}{l}21.9 \\
14.8\end{array}$ & $\begin{array}{l}30.3 \\
16.1\end{array}$ & $\begin{array}{l}4.1 \\
3.7\end{array}$ \\
\hline 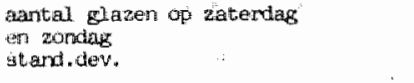 & $\begin{array}{l}1.2 \\
1.6\end{array}$ & $\begin{array}{l}0.8 \\
1.3\end{array}$ & $\begin{array}{l}7.9 \\
5.7\end{array}$ & $\begin{array}{l}7.5 \\
5.3\end{array}$ & $\begin{array}{r}12.3 \\
6.7\end{array}$ & 1.9 \\
\hline $\begin{array}{l}\text { bantal. giazeri op maan- } \\
\text { dage t/m ur ijodag } \\
\text { stand dew. }\end{array}$ & $\begin{array}{l}0.8 \\
2.0\end{array}$ & $\begin{array}{l}0.7 \\
1.9\end{array}$ & $\begin{array}{l}14 \times 1 \\
10.2\end{array}$ & $\begin{array}{l}13.6 \\
10.6\end{array}$ & $\begin{array}{r}7.9 \\
12.7\end{array}$ & $\begin{array}{l}2.2 \\
3.3\end{array}$ \\
\hline 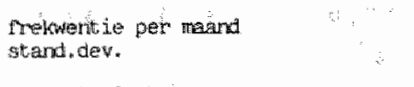 & $\begin{array}{l}3.2 \\
2.4\end{array}$ & $\begin{array}{l}3.0 \\
2.4\end{array}$ & $\begin{array}{r}31.1 \\
0.6\end{array}$ & $\begin{array}{r}30.8 \\
5.3\end{array}$ & $\begin{array}{l}9.7 \\
4.7\end{array}$ & $\begin{array}{r}11.6 \\
3.4\end{array}$ \\
\hline $\begin{array}{l}\text { hoverel he ad per keer } \\
\text { stiand. dev. }\end{array}$ & $\begin{array}{l}1.11 \\
1.3\end{array}$ & $\begin{array}{l}0.9 \\
1.1\end{array}$ & $\begin{array}{l}3.7 \\
2.3\end{array}$ & $\begin{array}{l}3.5 \\
2.3\end{array}$ & 7.44 & $\begin{array}{l}1.6 \\
1.1\end{array}$ \\
\hline $\begin{array}{l}\text { rrokwernte care bezolk per naward } \\
\text { stand.cev. }\end{array}$ & $\begin{array}{l}1.2 \\
1.7\end{array}$ & $\begin{array}{l}1.3 \\
1.7\end{array}$ & $\frac{2.5}{2.6}$ & $\begin{array}{l}2.41 \\
2.3\end{array}$ & $\begin{array}{l}4.0 \\
3.3\end{array}$ & $\begin{array}{l}2.7 \\
2.7\end{array}$ \\
\hline 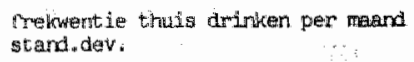 & $\begin{array}{l}2.3 \\
2.2\end{array}$ & $\begin{array}{l}2.5 \\
2.3\end{array}$ & $\begin{array}{r}28.2 \\
4.8\end{array}$ & $\begin{array}{r}28.5 \\
4.6\end{array}$ & $\begin{array}{l}4.8 \\
4.4 \\
4\end{array}$ & $\begin{array}{l}9.0 \\
3.9\end{array}$ \\
\hline
\end{tabular}

Wordt gekeken naar de kriterla waarmee de drinkpatronen gedefiniëerd zifn, den kan het lijken alsof er tussen de drInkpatronen slechts geringe verschillen in drinkgedrag bestaan. Wordt echter gekeken naar de gemiddelde waarden voor onderschelden aspekten van drinkgedrag (tabel 4), dan blijkt sprake te zljn van beduldende verschillen, die het rechtvaardigen on de drinkpatronen (wellicht met ultzondering van het als mengvorm benoemde drinkpatroon) als karakterlstieke en sterk verschillende vormen van drankgebrulk te zlen. Dok b1j toetsing blijken er, op één ultzondering na, signifikante verschillen te bestaan tussen de diverse aspekten van de drinkpatronen (tabel 2 uit bljlage). De uftzondering is dat er in Limburg geen signifikant verschil is in gemiddeld 
aantal glazen per week blj perlodiek veel drinken (20.3 glazen) en b1jna dagel1 jks thulsdrinken (22.0 glazer). Op deze relevante ultzonderlng zal in hoofdstuk VIII worden teruggekomen.

De rationale voor de bet1teling "incldenteel matig drankgebrulk" wordt duidel1jk als de gemiddelde waarde voor frekwentle van drankgebrulk (minder dan 1 maal per week) en de hoeveelheld per keer (onstreeks 1 glas) wordt nagegaan. B1y het drinkpatroon bijna dagel1Jks thuls drinken of periodiek veel drinken is het gemiddeld aantal glazen dat per week wordt gedronken mim 10 keer hoger.

Zo 1 s er ook een goede reden voor de betiteling "bijna dage$11 \mathrm{jks}$ thuls drinken" als de gemlddelde waarde voor de frekwentle van drankgebrulk b1f dit drinkpatroon in aamerking wordt genomen. Er wordt op alle dagen van de maand gedronken en op gemiddeld 28 dagen van de maand in hulselijk verband. Wat overlgens opvalt is dat de gemiddelde hoeveelheid per keer -3.5 en 3.7 glazen in respekt1evel1 jk Rotterdam en Limburg- zeker nilet laag genoend kan worden.

Alleen bif degenen die perlodiek veel drinken is het gemiddeld aantal glazen per keer hoger: 7.4. glazen.

Deze hoge hoeveelheld per keer is één van de karakterlst1eken warmee laatstgenoemd drinkpatroon zlch van de andere ondersche1dt. De andere karakteristlek is het verschil in konsumpt1e op doordeweekse en weekenddagen. Op de twee weekenddagen tezamen worden gemiddeld 12.7 glazen gedronken, op de v1Jf doordeweekse dagen minder: 7.9 glazen.

Dit drinkpatroon zou dan ook betiteld kunnen worden als weekenddrinken, ware het niet dat voor alle drinkpatronen, $z 1 j$ het veel minder sterk, geldt dat in het weekend meer gedronken wordt dan door de week.

Zoals gezegd, is het als mengvom benoemde drinkpatroon een minder karakteristleke wijze van drankgebruik. De overeenkomst van dit drinkpatroon met incldenteel matig drankgebrulk is dat er op doordeweekse of weekenddagen niet meer dan drle glazen wordt gedronken, het verschll is dat de frekwentle van drankgebmulk hoger is: gemiddeld mulm 11 keer per maand tegen 3 keer per maand blj incidenteel matig drankgebrulk. Het voomaamste verschil met bijna dagel1jks thuis drinken is dat er minder vaak wordt gedronken. 
$\frac{x}{4 t}$

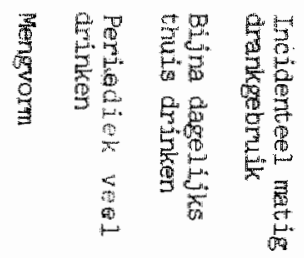

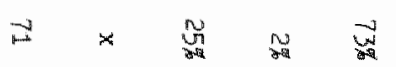

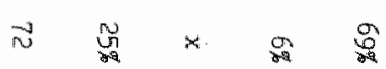

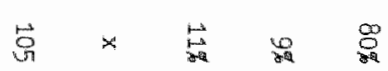

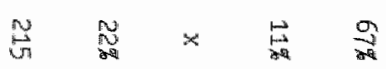

$\pm \quad x \quad \frac{5}{29}$ or

ज小

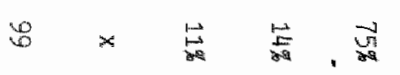

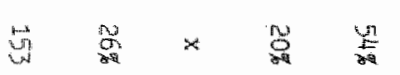

zit

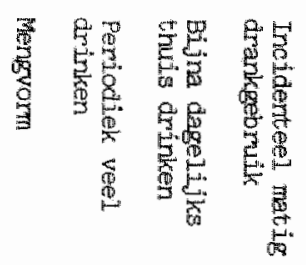

骂

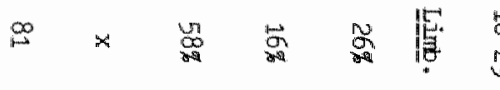

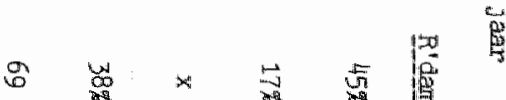
岁 $x$ 等

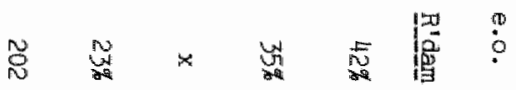

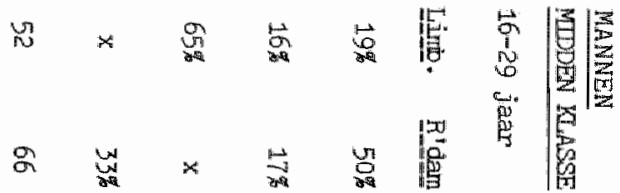

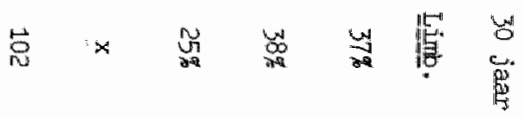

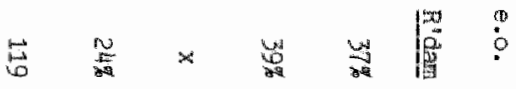

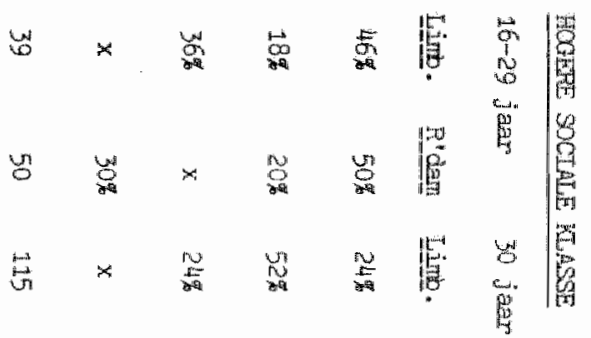

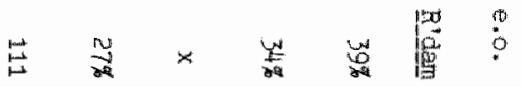

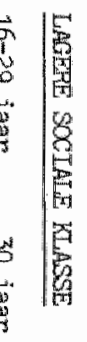


VI. 3. Versch11len in drinkpatroon tussen statusgroeperingen

on snel verschillen in drinkpatroon tussen sociale groeperingen te achterhalen is een diskriminantanalyse uitgevoerd ten aanzlen van drinkpatronen met de volgende onafhankelijke varlabelen:

geslacht, leeft1jd, (16-29/30 Jaar en ouder), soclale klasse (laag, midden, hoog), onkerkelijk ( $\mathrm{ja} / \mathrm{nee})$, rooms-kathollek ( $\mathrm{Ja} /$ nee), protestant ( $\mathrm{Ja} /$ nee), gezinssituatle (met/zonder partner), werksituatle (wel/nlet onvrijwillig werkloos).

In deze analyse werden ook gezinssituatie en werksituatie opgenomen om na te gaan of wellicht relevantere en grotere verschillen in drinkpatroon bestonden naar gelang positie in werk- en/of gezinssituatie dan naargelang statusgroepering. Dit bleek overigens niet het geval te zijn.

De variabelen die zowel in Limburg als Rotterdam gemeenschappel1,jk het beste onderscheldden tussen de drie in Limburg en Rotterdam gangbare drinkpatronen waren de statuskenmerken geslacht, leeft1jd en soclale klasse.

De volgende stap was om voor statusgroeperingen gedefiniëerd in termen van geslacht, leeftijd en soctale klasse, de verdeling van drinkpatronen weer te geven. In tabel 5 is de uitkomst daarvan te vinden.

B1j de bespreking zal hoofdzakelljk schema III worden gevolgd. Daarin is aangegeven in welke statusgroeperingen een bepaald drinkpatroon sterk domineert. Als grens voor "dominantie" 1 s genomen dat aan 50\% of meer van de drinkers in een statusgroepering het betreffend drinkpatroon kan worden toegeschreven. Tevens $z 1 \mathrm{jn}$ in dit schema, met voorbl Jgaan aan de preclese percentages, ook kleinere verschillen in het vóórkomen van drinkpatronen in de onderscheiden statusgroeperingen weergegeven. 
Sehema III: Statusgroeperingen waarin meenderheid van da drinkers een specifiek drinkpatroon kan worden toegesehreven

\section{LTMBUAC}

Incidenteel ratig drankgeoruik

Periodiek vee! orinken

Bijna dagelijks thuis drirken

Versonilen natr sociale klasse:

Verschilien naar leeftijd:

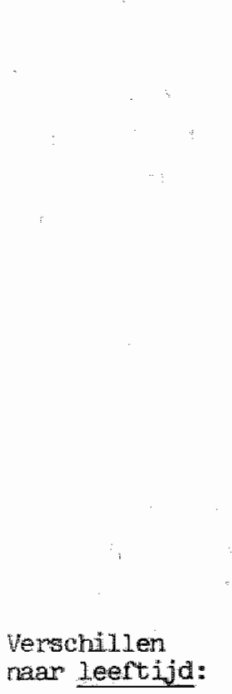

Bij mannen en vrouwen
Vrouwen ongeacht leer ijd en sociale klasse

Mannen jonger dam 30 jaar uit lagere en middenklasse

Marnen ouder dan 30 jaar uit de hogere klasse
ROTIMDAN

Vrouwen onseacht Leeftijd on met uitzondering van hom gere sociale kasse

Mannen jonger dar 30 jaar ujt midden- en togeme klasse *afname periodiek veel drinken bij populatie ouder dan 30 jaar

*toename bijna dagelijks thuis drinken bij: populatie ouder dan 30 jaar

Bij.j mannen wit lagereen midden klasse

*toename incidenteel matig drankgebruik bij populatie ouder dan 30 jaar
- in hogere klasse hoger percentagige dat bijna dagel $1, j \mathrm{ks}$ thuis dirjnkt dan In middenen lagsere klasse

BH,j mannen en virouwen

*aframe van mengvorm bij populatie ouder dan 30 jaar, het sterkst in middenklasse en mannen uitt lagere klesse

toename bijna dage $1, j \mathrm{ks}$ thuis drinken bij populatie ouder dan 30 jaar

Bij mannen uit midden- en hogere klasse

* afname lincidenteel matig drankgebruik bij populatie ouder dan 30 jaar 
Ten eerste valt op dat in Llmburg 9 van de onderschelden statusgroeperingen, in Rotterdam een kleiner aantal, name$11 \mathrm{kk} 6$, in meerderheld één bepaald drinkpatroon kan worden toegeschreven.

In Rotterdam domineert in elk van deze zes statusgroeperingen het incidenteel matig drinken.

In Llmburg echter zljn er naast statusgroeperingen waar een meerderheld incidenteel matig drinkt (vrouwen) ook statusgroeperingen waarin een ander drinkpatroon sterk dominant 1s: perlodiek veel drinken b1j mannen Jonger dan 30 jaar u1t midden-/en lagere klasse) en b1jna dagel1jks thulsdrinken bly mannen ouder dan 30 jaar utt de hogere klasse.

Voor die statusgroeperingen in Limburg waar periodiek veel drinken of b1jna dagel1jks drankgebmulk domineert, vormt drankgebrulk ook sterker dan in Rotterdam in enige statusgroepering het geval is, een 'stijlelement' van hun statusrol. Immers, vergeleken met incidenteel mat1g drankgebruik, zifn perlodiek veel drinken en bljna dagel1jks thuis drinken sterker geprononceerde vormen van drankgebmulk. Waar en meerderheld van een statusgroeperıng één van deze karakteristleke vormen van drankgebrulk toegeschreven kan worden, kan gesproken worden van een stiglelement in de statusrol: men gaat op specifleke wljze met alkohollese drank om en daamee onderscheldt men zich van andere groeperingen.

Een bespreking van de verschillen in drinkpatroon naar, achtereenvolgens, geslacht, soclale klasse en leeftljd leldt tot een aantal relevante bevindingen.

op éen ultzondering na (vrouwen uit de hogere k].asse in Rotterdam) geldt voor Rotterdam en Limburg dat een meerderheld van de vrouwen tot de incldenteel mat1ge drinkers gerekend kunnen worden. Vergeleken met mannen $1 \mathrm{~s}$ de uniformiteit in drinkpatroon bif vrouwen dan ook veel groter.

Het is waarschilnl1.jk dat de mate waarin vrouwen zich beperken tot incldenteel matlg drankgebmulk ook beinvloed wordt door de houding van vele mannen dle andere vormen van drankgebrulk voor vrouwen als niet passend of te riskant afwljzen. Tevens moet van invloed worden geacht dat vrouwen ten aanzlen van het drankgebrulk van sexegenoten, strengere normen hanteren dan ten aanzlen van het drankgebrulk van mannen (Knibbe, 1982; pag. 35).

Zoals gezegd vomen vrouwen ult de hogere klasse in Rotterdam een ultzonderlng. Precleser bekeken blifken zowel in 
Rotterdam als in Limburg in de hogere klasse de verschtllen in drinkpatroon tussen mannen en vrouwen geringer te $z 1 . \mathrm{Jn}$ dan in de midden en lagere klasse. Deze mogelljkheld werd, onder verwifzing naar de ontwikkelingen in het roken bij vrouwen, al geopperd in hoofdstuk II. Het duidelijkst laten de verschillen in drinkpatroon tussen mannen en vrouwen zich 1llustreren aan verschillen in de mate waarin vrouwen dan wel mannen tot de incidenteel matige drinkers gerekend kunnen worden.

In Rotterdam b. v. is in de hogere klasse het verschil tussen mannen en vrouwen te verwaarlozen. B1f respondenten ouder dan 30 jaar uit de midden- en lagere klasse kumnen echter respektievelijk $17 \%$ en $25 \%$ meer vrouwen dan mannen tot de Incidenteel matige drinkers worden gerekend.

Het geringere verschil in drinkpatroon tussen mannen en vrouwen in de hogere klasse is naar het zlch laat aanzlen, gevolg van een proces dat onstreeks 1970 is begonnen. Uit longitudinale onderzoeksgegevens die van Reek e.a. (1983) presenteren blijkt namelijk dat bij de hoger opgelelde vrouwen -1.c. vrouwen uft de hogere klasse- na 1970 het konsumptienivo sterker is gestegen dan bij hoger opgeleide mannen of bif lager opgelelde vrouwen. Waar er over het geheel genomen blijkens de resultaten van van Reek e.a. er geen emanclpatorlese ontwikkelingen in drankgebrulk $\mathrm{zl} j \mathrm{n}$ aan te wifzen sinds 1958, vormen vrouwen ult de hogere klasse hlerop wellicht een uitzondering. Blijkens $\mathrm{ml}$ in gegevens kan daaraan toegevoegd worden dat in Rotterdam in de hogere klasse deze emanclpatle wat betreft gangbare dr.inkpatronen min of meer voltoold geacht kan worden, in Limburg echter nlet.

De differentlatie in drinkpatronen naar soclale klasse geldt In Rotterdam voornamelljk voor vrouwen, in Limburg zowel voor mannen als voor vrouwen. Behalve de reeds besproken verschillen in drinkpatronen naar soclale klasse bif vrouwen, zifn er bif mannen in Limburg verschillen naar soclale klasse in perlodiek veel drinken (bl.j mannen Jonger dan 30 jaar) en bifna dagelifks thuis drinken (bif mannen ouder dan 30 jaar).

Bezien we de verschilien in drinkpatronen naar leeftijd, dan valt op dat zowel in Rotterdam als in Limburg voor de gehele populatie geldt dat bijna dagelijks thuis drinken vaker 
voorkont b1f respondenten ouder dan 30 jaar. In L1mburg geldt tevens voor de gehele populatie dat bij de ouderen een klelner percentage perlodiek veel drinkt; in Rotterdam geldt, met uitzondering van vrouwen uft de lagere en hogere klasse, dat bif de oudere populatie een lager percentage de mengvorm als drinkpatroon kan worden toegeschreven. Jongere en oudere mannen verschillen ook in incidenteel matig drankgebmulk. De verschilien zi.jn echter ntet identlek in Limburg en Rotterdam. In Rotterdam is b1j oudere mannen uit de midden- en hogere klasse het percentage incidentele matige drinkers lager; in Limburg geldt dit alleen voor mannen ult de hogere klasse. In Limburg zljn er bif oudere mannen ult lagere en middenklasse meer incidenteel matige drinkers dan bif jongere mannen, een verschil dat zich in Rotterdam niet voordoet.

De hier gepresenteerde resultaten wat betref't drinkpatroon vertonen overeenkomst met de resultaten van Philipsen e.a. (1983,1984) Deze auteurs beschrifven de ontwlkkeling van drinkpatronen. Op grond van gegevens over drankgebruik uit 1958 gaan ze ervan utt dat toendertijd de meerderheld van de Nederlandse bevolking tot de incidenteel matige drinkers gerekend kon worden, en dat er voomamel1jk thuis werd gedronken. Sindsdien hebben zlch twee trends in drankgebrulk voorgedaan die uiteindelijk in drie drinkpatronen resulteerden. Eén trend is dat naast drankgebruik thuis ook drankgebrulk buitenshuis met name in het weekend tot de gewoontes gaat behoren hetgeen resulteert in een drinkpatroon dat te vergelijken is met periodiek veel drinken of de mengvorm in Rotterdam. Deze trend is vooral bif jongeren en het sterkst bif mannen te vinden. De andere trend is een sterke uitbre1ding van het aantal dagen waarop thuis wordt gedronken, hetgeen resulteert in een drinkpatroon dat hiler als bijna dage11Jks thuis drinken is benoemd. Deze trend is vooral blf ouderen te vinden en het sterkst in de hogere sociale klassen. Daarnaast stellen $\mathrm{zlj}$ vast dat bif vrouwen het oorspronkel1jke Incidenteel matig drankgebruik als drinkpatroon bllifft overheersen.

Gaan we na wat de hier gepresenteerde resultaten betekenen voor de door ons geformuleerde hypothese, dan is er geen aanlelding deze te verwerpen, ook al worden er geen relevante verschillen in drinkpatroon gevonden tussen godsdienstige 
groeperingen. Tussen statusgroeperingen, gedefinleerd door de overlge statuskenmerken worden er wel relevante versch1llen in drinkpatroon gevonden.

Samenvatting

In dit hoofdstuk is nagegaan of voor de volgende twee hypothesen steun is te vinden:

De verscheidenheid aan drinkgedrag van individuen laat

wich samenvatten in enkele gangbare drinkpatronen.

Er zijn verschillen in gangbaar drinkpatroon tussen statusgroeperingen gedefiniëerd door tén of meer van de status-

kenmerken geslacht, leeftijd sociale klasse en godsdienst. Voor Limburg en Rotterdam werden op indukatieve wijze drle gangbare drinkpatronen geformuleerd.

Twee daarvan "b1jna dagelljks thuis drinken" en "incidenteel matig drinken" komen zowel in Limburg als Rotterdam voor. "Perlodiek veel drinken", gekenmerkt door een hoge konsumptie op weekenddagen, kan alleen in Limburg als gangbaar drinkpatroon worden gekenmerkt. Het drinkpatroon benoemd als "mengvorm", waarb1f vaker gedronken wordt dan b1f inc1denteel matig drankgebrulk en minder vaak dan bif bijna dagelifks thuis drinken, komt alleen in Rotterdam voor.

Gezien het felt dat in Limburg aan $73 \%$ en in Rotterdam aan 78\% van de drinkers één van de gangbare drinkpatronen kan worden toegekend, kan de eerste hypothese bevestigd worden geacht.

In Llmburg en Rotterdam konden, overeenkomstig de hypothese, verschillen in drinkpatroon tussen statusgroeperingen gedefinlëerd in termen van geslacht, leeftijd en soclale klasse worden gekonstateerd. Er waren geen relevante verschillen in drinkpatroon naar godsdienst.

Het grootste verschil in drinkpatroon is te vinden tussen mannen en vrouwen. In Limburg en Rotterdam kan, op eén uitzondering na, aan vrouwen in meerderheld een drinkpatroon van incidenteel matig drankgebruik worden toegeschreven. De uftzondering betreft vrouwen ult de hogere klasse in Rotterdam b1j wie een even grote diversiteit aan drinkpatronen is te konstateren als bij mannen uit de hogere klasse in Rotterdam. 
Precleser bekeken bl1jkt voor zowel Rotterdam als Limburg te gelden dat in de hogere soclale klasse het verschll tussen mannen en vrouwen in drinkpatroon het kleinst 1s. Gezlen de longltudinale gegevens die van Reek e.a. (1983) voor Nederland presenteren, 13 warschifnl1fk anstreeks 1970 b1j vrouwen in de hogere klasse de emanclpatle ten aanzlen van drinkpatronen op gang gekomen. Bl1Jkens de hier gepresenteerde gegevens kan vermoed worden dat dit proces in Rotterdam in de hogere klasse vrlywel voltoold is, in Limburg daarentegen nog gaande.

In Limburg, echter niet in Rotterdam, zifn er ook bif mannen verschillen in drinkpatronen naar soclale klasse. Het voornaamste verschll in Limburg is wel dat bif de mannen ouder dan 30 jaar uit de hogere klasse een meerderheld bljna dagel1jks thuis drinkt. B1J mannen ouder dan 30 jaar ult de lagere en middenklasse in Limburg kan slechts onstreeks een kwart het drinkpatroon van b1jna dagel1jks thuis drinken worden toegeschreven.

Naar leeft1jd bezien valt op dat, zowel in Limburg als in Rotterdam, bifna dagel1Jks thuls drinken vaker in de leeftijdskategorle ouder dan 30 jaar voorkont dan bij degenen dle Jonger dan 30 Jaar z1Jn.

Wordt afgezien van de klelnere verschillen in drinkpatroon tussen jongeren en ouderen, dan blifft één ultkomst over als vermeldenswaardig. In Limburg kan van de mannen jonger dan 30 Jaar ult midden- en lagere klasse aan een ruime meerderheld een arıinkpatroon van periodlek veel drinken worden toegeschreven. BI. mannen ouder dan 30 jaar is dat een minderheld varlërend $\operatorname{van} 32 \%$ in de lagere klasse tot $38 \%$ in de middenklasse.

Op twee punten werden opvallende verschllien tussen enerziljds Limburg anderzijds Rotterdam gevonden:

- Het in Limburg gangbare drinkpatroon periodiek veel drinken bevat veel duldel1jker aanwljzingen voor drankgebruik dan het in Rotterdam gangbare drinkpatroon benoemd als "mengrom"

- In Limburg kan bij 9 van de onderschelden statusgroeperingen, $50 \%$ of meer van de drinkers één speciflek drinkpatroon worden toegekend. In Rotterdam kan dat slechts bij 6 statusgroeperingen

Beide felten tezamen laten mljns inzlens de konklusle toe 
dat in Limburg drankgebruik een duidelijker een sterker geIntegreerd element van de statusrol 1s. Preclezer bekeken blijkt dit verschil in integratie van drankgebrulk in de statusrol zich vooral toe te spitsen op mannen in Limburg en Rotterdam.

In de volgende hoofdstukken zal blijken dat dit -nlet verwachte- verscht1 in integratie van drankgebrulk in de statusrol een belangrijke verklarende faktor is voor andere verschillen tussen Lifmburg en Rotterdam. 


\section{Faktoren van invloed op intensivering}

\section{van drankgebruik}

VII. 1. Inlelding

In dit hoofdstuk zal nagegaan worden welke faktoren van Invloed $z 1 \mathrm{Jn}$ op intensivering van drankgebruik. In hoofdstuk III z1jn daarover een aantal hypothesen geformuleerd. In onderstaande flguur is in het omllynde gedeelde aangegeven welke samenhangen verwacht worden.

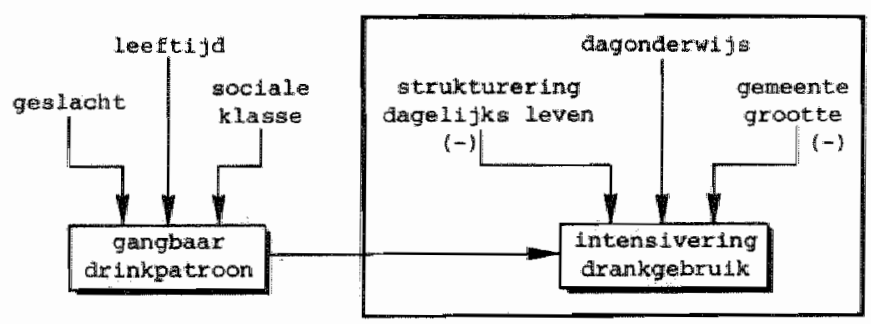

De hypothesen luiden als volgt:

Bij een weinig gestruktureerd dagelijks leven is er vaker sprake van intensief drankgebruik. In grotere gemeenten is het gemiddeld konsumptienivo hoger dan in kleine gemeenten.

Daarbif werden bif de eerste hypothese de volgende beperkingen aangegeven:

- statusgroeperingen die verschillen in drinkpatroon kunnen verschillen in de mate waarin de verwachte tendens zlch voordoet;

- voorzover een groepering met een weinig gestruktureerd dagel1jks leven ook wordt gekermerkt door een gemlddeld slechtere gezondhe1d, 1.c. arbeldsongeschikten, zal mogelifk geen intensivering van drankgebmulk optreden. 
De indikatoren voor een wein $1 \mathrm{~g}$ gestruktureerd dagel1jks leven zifn gezocht in de werk- en gezinssituatle. Ten aanzlen van degenen die dagonderwI fs volgen is geen hypothese geformuleerd. Deze zullen echter wel vergeleken worden met werkenden.

Als voornaamste hypothese beschouw ik de hypothese betreffende het verband tussen een weinig gestruktureerd dagelijks leven en intensivering van drankgebmulk. Hieraan zal dan ook in paragraaf VII.2. de meeste aandacht worden gegeven. In paragraaf VII.3. en VII. 4. zal achtereenvolgens de invloed van dagonderw1 is volgen en urbanisatlegraad worden besproken. Het hoofdstuk wordt besloten met een samenvatting en diskussie van de resultaten.

\section{VII.2. 1. Konstruktie van de varlabele strukturering van het dagel1 jks leven}

De variabele strukturering van het dagelijks leven is gevormd met behulp van de volgende Indikatoren:

- arbeldsverplichtingen bulten gezinsverband; werkzoekenden, arbeldsonge schlkten, gepensioneerden en hulsvrouwen werden geacht geen arbeidsverplichtingen bulten gezinsverband te hebben

- samenleven met een partner; gescheldenen, verweduwden en degenen die opgaven noolt gehuwd te zifn en niet samen te leven werden geacht zonder partner te leven

- zorg voor thulswonende kinderen; zowel degenen die geen kinderen hebben als degenen wier kinderen buttenshuls wonen werden geacht geen zorg voor thulswonende kinderen te hebben.

Al naar gelang een respondent positlef skoorde op éên of meer van de genoemde indikatoren, werd één punt op de varıabele strukturering van het dagellyks leven toegekend. De skore op deze variabele kan derhalve variëren van 0 punten -geen arbeidsverplichtingen buiten het gezin, geen partner en geen zorg voor thuiswonende kinderen- tot 3 punten. In biflagen I, tabel $3 \mathrm{zl}$ jn de frekwentieverdelingen -apart voor mannen en vrouwen- weergegeven. Zoals te verwachten komt blj vrouwen minder vaak een skore van drle voor, ondat gehuwde vrouwen met thuiswonende kinderen minder vaak dan gehuwde mannen met thuiswonende kinderen bultenshuls werken. 
VII. 2.2. Opzet van de analyse

Het voorgaande hoofdstuk heeft opgeleverd dat de statusfaktoren geslacht, leeftijd en sociale klasse, z1j het in verschillende mate in Limburg en Rotterdam, samenhangen met drinkpatronen. On twee redenen worden deze statusfaktoren blif de analyse betrokken:

- Intensivering van drankgebruik mag niet verward worden met in een samenleving normaal geachte verschilien in konsumptienivo tussen statusgroeperingen,

- statusgroeperingen kumnen verschilien in de mate waarin een weinig gestruktureerd dagelijks leven leldt tot intensivering van drankgebruik.

Met de faktor geslacht is rekenting gehouden door de analyses geschelden voor mannen en vrouwen ult te voeren. Er wordt in het hiernavolgende daardoor in felte gewerkt met vier onderzoekspopulaties: mannen en vrouwen in Limburg en Rotterdam. De faktoren soclale klasse en leeftijd worden als kontrole variabelen in de analyse opgenomen.

Het voomaamste problemen dat zich bif de opzet van de analyse voordeed was een analyse techntek te vinden die adekwaat rekening houdt met de mogelljkheld dat het verband tussen strukturering van het dagelljks bestaan en konsumptie niet lineair is maar, bifvoorbeeld, kromlifnig.

In het algemeen kan verondersteld worden dat, waar het riskante gewoonten betreft, in een groepering tegelifkertijd een tendens tot intensivering als (In reaktie op het risiko) tot minimalisering van de betreffende gewoonte kan optreden. Voor Limburg werd wat betreft konsumptle op doordeweekse dagen een tendens daartoe gevonden bIy werkzoekenden. BIf werkzoekenden bleek, vergeleken met werkenden, zowel het percentage dat minder dan één glas op doordeweekse dagen drinkt ( $53 \%$ versus $49 \%$ ) hoger te $\mathrm{z} 1 \mathrm{Jn}$ als ook het percentage dat gemiddeld meer dan vler glazen op doordeweekse dagen delnkt (27\% versus 16\%; Knibbe, 1982).

De mogel1jkheld van een kroml1jnig verband heeft er in belangrifke mate toe bifgedragen een analysetechniek te kiezen die niet opgenomen is in het statistles pakket dat doorgaans In de soclale wetenschappen wordt gebrulkt, het SPSS-programma (de Nie, e.a. 1975). De multivariate technieken in het SPSS programa hebben allen als vooronderstelling dat er 
sprake is van een linealr verband tussen varlabelen. Weliswaar zijn er mogelijkheden on onder deze vooronderstelling ult te komen, geen is echter erg bevredigend en adekwaat. Besloten is met logit-analyse te werken, een analyse-techniek die een antwoord bledt op het probleem van mogel1jke kromlijnige verbanden en statlstles gezlen bifzonder geschikt is indien zoals hiler, wordt gewerkt met een zogeheten multinominaal sample.

Logitanalyse laat zich beschrijven als een proces waarin, uitgaande van het eenvoudigste model (in deze studle is dat een model waarin slechts één term voor de onderlinge interaktie tussen statusfaktoren en strukturering van het dage$11, j \mathrm{ks}$ leven is opgenomen) nagegaan wordt of het toevoegen van andere termen $-b v$. een direkt verband tussen strukturering van het dagel1jks leven en konsumptle -leldt tot een signifikante verbetering in de voorspelling van de afhanke11.jke variabele. (zie ook b1jlage II; Finebers, 1980) In het proces van selektle van het model dat het meest adekwaat de afhankel1jke varlabele voorspelt, zljn de volgende elementen te onderschelden:

- er is in alle gevalien een term opgenomen in het model die staat voor de onderlinge interaktle tussen onafhankelifke en kontrolevartabele $(n)$.

Zodoende wordt gekontroleerd voor de ongel1jke sprelding van strukturering van het dagel1jks leven over statusgroeperingen.

- er wordt nagegaan of er interaktie 1s van statusfakto$r(e n)$ en strukturering van het dagel1 jks leven met konsumptie. Een voorbeeld van zo'n interaktle zou zijn als b1f jongeren een welnlg gestruktureerd dagel1.jks leven leldt tot matiging van drankgebrut $k$, bil ouderen daarentegen tot Intensivering van drankgebrulk.

- nagegaan wordt of, gegeven de interaktle tussen de kontrole- en onafhankelljke vartabele( $n)$ onderling en gegeven de (mogel1jke) Interaktle van kontrolevariabelen en onafhankel1 jke varlabelen met konsumptie, er nog signiflkante voorultgang in de voorspeli1ng geboekt kan worden door een direkte relatie tussen onafhankel1 Jke en afhankel1jke varlabele (1.c. konsumptienivo) te veronderstellen. De slgnifikantle van de voorultgang in voorspelling is nagegaan met de pearson chi-kwadraat flt en de Iog-1ikelyhood fit. (B.M. D. P., W.J. Dixon e.a. 1981). De ultkomsten van deze analyse die hier gepresenteerd zullen 
worden zlin de "multiplikatleve effekten", een maat die aangeeft in hoeverre er naar gelang strukturering van het dage$11 \mathrm{ks}$ leven verschilien zi.Jn in "welnig" drinken en "veel" drinken (de operationalisering van "welnig" en "veel" drinken zal later gegeven worden).

ondat er nlet bly voorbaat van ultgegaan kan worden dat de relatle tussen onafhankelljke en afhankel1jke varlabele 11nealr 1s, werd als er sprake bleek van een effekt van de onafthankel Ijke varlabele zowel het mult1plikatlef effekt voor weinls als voor veel drinken berekend.

Slechts waar eén of meer van de statusfaktoren en/of de varlabele strukturering van het dagel1jks leven bijdraagt aan het voorspellen van konsumptlenlvo zlfn de multiplikatleve effekten berekend.

Het "welnif drinken' is in alle analyses op dezelfde wijze geoperationallseerd: minder dan één glas per week. Het veel drinken is echter verschillend geoperationaliseerd ondat er grote verschilien in gemiddeld konsumptientvo bestaan tussen mannen en vrouwen en bif mannen tussen Limburg en Rotterdam. Zou In alle populaties eenzelfde operationalisatle van veel drinken worden aangehouden dan zouden in sommige populaties de aantallen veeldrinkers dusdanlg klein $z 1 j n$ dat analyse onmogel1.jk wordt. Belangrljker is echter een Inhoudelijk argument. U1telndel1jk gaat het hier on intensivering van drankgebrulk. Deze intenslvering moet gerelateerd worden aan wat "gewoonlijk" gedronken wordt on relevante verschillen in alkoholkonsumptle op te sporen. Het meer dan gebruikelijk drinken -1.c. "veel arı́nken"- is, vóôn de analyse begon, met een grof krtterlum vastgesteld, namel1 Jk dat 10 tot $13 \%$ van de onderzoekspopulatle in de hoogste konsumptiekategorle moest vallen. Dit betekende dat voor vrouwen het veel drinken 18 geoperatlonallseend als 14 glazen of meer per week; yoor mannen in Limburg als 28 glazen of meer per week en voor mannen in Rotterdam als 21 glazen of meer per week.

De presentatie van de resultaten aangaande de invloed van strukturering van het dagel1jks leven, valt in drie delen ulteen:

- verschlllen naar gelang skore op de varlabele strukturering van het dage11jks leven,

- verschilien naar gelang werk- en gezinssituatie. 
VII.3.1. Strukturering van het dagelljks bestaan

De in deze paragraaf' te bespreken resultaten $z 1$ fn uitkomsten van analyses waarin de volgende variabelen zifn opgenomen: leeftijd (<30 faar/ > 30 Jaar), sociale klasse (laas/midden/hoog), strukturering van het dagelijks bestaan en alkohol konsumptie. Daarbl $j$ zijn de waarden 0 en 1 van de varlabele strukturering van het dagelijks bestaan samengenomen om voldoende aantallen voor de analyse te hebben.

Ik wil beginnen de voor vrouwen gevonden resultaten te bespreken, ondat deze het snelst en eenvoudigst een konklusle toelaten.

Noch in Limburg, noch in Rotterdam kon voor vrouwen aangetoond worden dat er naargelang strukturering van het dagelifks bestaan verschillen zljn in intensitelt van drankgebruik. Er zifn ook geen verschillen in welnig drinken. Er zijn in Limburg wel verschillen naar gelang leeftijd en soclale klasse en in Rotterdam naar gelang soclale klasse. Voor de volledigheid zijn hieronder in de tabel de multiplikatleve effekten weergegeven.

De konstante in de tabel duldt op de kans om tot de veel of weinigdrinkers te behoren, ongeacht statusgroepering.

De multiplikatieve effekten zljn te interpreteren als een maat voor de kans dat men tot de welnigdrinkers behoort (le kolom) dan wel tot de veeldrinkers (2e kolom).

In Limburg blijkt naast een bescheiden direkte Invloed van sociale klasse en leeft1jd, ook sprake te zijn van interakt1e van soclale klasse en leeftijd met alkoholkonsumptie. Bif jongere vrouwen ult de lagere klasse 1 s zowel de kans op veel als op weinig drinken kleiner dan in de midden- en hogere klasse. Daarentegen is bif oudere vrouwen ult de lagere klasse sprake van een vergelljkenderwl js hogere kans op veel én weinig drinken.

In Rotterdam is er bij vrouwen uft de hogere klasse sprake van een lagere kans op welnig drinken en een hogere kans op veel drinken. 


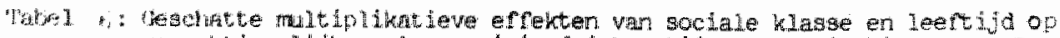

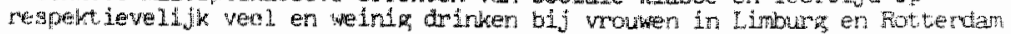

\section{LIMENFT}

$$
\begin{aligned}
& 41 \mathrm{gl} \text {. per wek } 714 \mathrm{kz} \text {. per werk }
\end{aligned}
$$

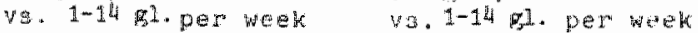

\begin{tabular}{|c|c|}
\hline Kanedurato & 0.48 \\
\hline 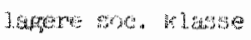 & 1.3 \\
\hline 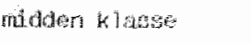 & 1.6 \\
\hline 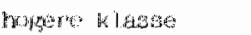 & 0.49 \\
\hline
\end{tabular}

\begin{tabular}{|c|c|c|c|}
\hline \multicolumn{2}{|c|}{$16-29$; a } & 0.82 & 0.98 \\
\hline 30 and & 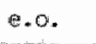 & 1.2 & 1.0 \\
\hline \multirow{3}{*}{$16-29$} & Lefgene & 0.72 & 0.82 \\
\hline & midden & 1.2 & 1.1 \\
\hline & hogere & 1.4 & 1.2 \\
\hline \multirow{3}{*}{730} & lagere & 1.4 & 1.2 \\
\hline & mitaden & 0.82 & 0.90 \\
\hline & hogere & 0.87 & 0.91 \\
\hline
\end{tabular}

ROTLERDAM

$\begin{array}{lll}\text { konstante } & 0.52 & 0.25 \\ \text { lagere soc. klasse } & 1.6 & 0.82 \\ \text { midden klasse } & 1.1 & 0.96 \\ \text { hoggere kllasise } & 0.57 & 1.3\end{array}$

B1. mannen in Limburg en Rotterdam is de varlabele strukturering van het dagelijks leven zowel van invloed op intensivering van drankgebmulk alsook op het weinig drinken. In Limburg is deze invloed blijkens tabel 7 vrij eenduidig aan te geven ondat de twee faktoren leeftijd en strukturerlng van het dagel1jks bestaan onafhankel1 jk van elkaar b1 fdragen aan een betere voorspelling van konsumptienlvo. 


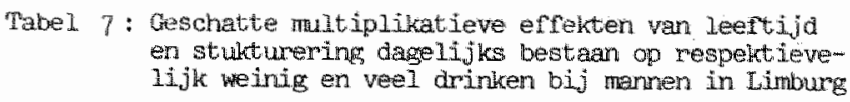

1 gias per week
vs. $1-28$ gl. per week
728 gater per wetk

Ws. 1-28 gil. per week

$\begin{array}{lll}\text { Konstante } & 0.16 & 0.33 \\ 16-29 \text { jatar } & 0.67 & 1.29 \\ 30 \text { jaar e.0. } & 1.5 & 0.78 \\ \text { Stmuktiarerings } & & \\ \text { dage 1. bestaan } & & \\ \text { skore 0. of 1 } & 1.4 & 1.3 \\ 2 & 1.3 & 1.1 \\ 3 & 0.56 & 0.73\end{array}$

In Limburg komt het veel drinken vaker voor bif jongere mannen, het weinig drinken daarentegen minder vaak. Deze verschillen zijn ongetwljfeld een ultvloelsel van de in Limburg grote verschillen in drinkpatroon tussen Jongere en oudere mannen.

Tevens blifkt dat bif een weinig gestruktureerd dagelijks leven -met name b1j een skore van 0,1 of 2- zowel het veel drinken alsook het weinig arinken vaker voor te komen. Wat betreft het veel drinken is deze ultkomst overeenkomstig de hypothese.

Voor Rotterdam zlet de tabel met de multiplikatieve effekten er veel ingewikkelder utt ondat er sprake is van interakt1e van soclale klasse, leeft1jd en strukturering van het dage$11 \mathrm{Jks}$ bestaan met alkoholkonsumptle. Daarom moesten niet alleen de multlplikatleve effekten van soclale klasse, leeft1jd en strukturering van het dagel1jks bestaan afzonder 11.jk worden berekend, maar ook van alle komblnatles van deze variabelen. Dit levert een tabel op die moelifjk leesbaar is en daarom in de bijlage is opgenomen. (tabel 4) Hier wordt een tabel gepresenteerd met de 'odds' voor strukturering van het dagelijks leven voor de verschlllende komblnatles van leeft1 jd en soclale klasse weergegeven. Deze tabel is lets gemakkel1jker te lezen. De 'odds' zijn de rat10's van de kans op respektllevel1jk weinig drinken en het veel drinken teri opzlchte van het 1-21 glazen per week drinken. 


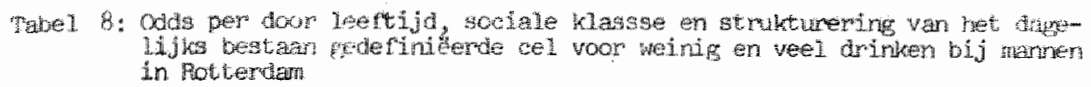

Mirder dan 1 glas nor woek

verous 1-21 glazer per weok

Leterijd

$16-29,3 \mathrm{arar}^{*}$

30 jagr en ouder

Meer dan 21 elazen per wesk verans $1-21$ glazen per week

leeftijal

16-29 jaar

30 jaer en ouder soclaye Hasse

Hags

mididen

hoogs

1 ates

midden

hoog:

Strukturering van het demelifk bestant

$0.0 f^{1}$
0.33
0.42
0.15
0.41
0.414
0.56

Strukturering van het dape 1.jis bastan

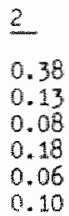

3

0.17

Q. 4.3

0.17

0.30

0.21

0.10

sociale klasse
laas
midden
hoos
laak
mid
hoog

sociale klasse

lavas midden

larger

hoogs

\subsection{1 \\ 0.67 \\ 0.37 \\ 0.54 \\ 0.53 \\ 0.50 \\ 0.44}

Met betrekking tot de hypothese laat zich uit deze tabel een duidelijke konklusie trekken. Met één ultzonderıng is er -overeenkomstig de hypothese- bij een weinig gestruktureerd dagel1jks bestaan (met name skore 0 en 1) sprake van een hogere kans op veel drinken. De ultzondering betreft Jongere mannen ult de lagere klasse. Daar doet zich een tegenovergestelde tendens voor: b1j een meer gestruktureerd dagelijks leven wordt intenstever gedronken. Daarmee onderschelden de jongere werkende gehuwde mannen met thulswonende klnderen ult de lagere klassse in Rotterdam zich vrlj sterk van werkende gehuwde mannen met thulswonenende kinderen ult middenen hagere klasse in Rotterdam.

Deze ultzonderling acht ik echter geen voldoende reden on de hypothese aangaande de invloed van strukturering van het dagelijks bestaan op intens 1vering van drankgebruik bij mannen te verwerpen.

Voor mannen ouder dan 30 Jaar in Rotterdam geldt, evenals in I.lmburg voor alle mannen, dat ók de kans op wein $1 g$ drinken hoger is bif een welnig gestruktureerd dagell jks leven. 
VII.3.2. Versch1llen in alkoholkonsumptle naar gelang werken gezinssituatie

Fen nadere analyse van verschillen in alkoholkonsumptie naar gelang werk- en gezinssituatle is ondernomen, om na te gaan of alle indikatoren voor een welnig gestruktureerd dagelijks bestaan in dezelfde mate tot verschillen in alkoholkonsumptie leiden. Tevens am voor zover mogelijk na te gaan of bij degenen zonder arbeldsverplichtingen respektlevelijk zonder partner, nog relevante verschillen zifn tussen subkategorleën als bv. arbeidsongeschikten en gepensioneerden. Bij werksituatle z1 fn de volgende kategorleën onderscheiden

- werkzoekend

- arbeidsongeschikt

- gepensioneerd

- huisvrouw

- arbeidsverplichtingen buiten het gezin

Voor gezInssituatie wordt de volgende indeling aangehouden:

- gescheiden

- weduwe/weduwnaar

- noolt gehuwd (en niet samenlevend met een partner)

- gehuwd (of samenlevend met een partner) zonder kInderen

- gehuwd (of samenlevend met een partner) met thuiswonende kinderen

- gehuwd (of samenlevend met een partner) met buitenshuis wonende kinderen

B1j degenen zonder partner kon vanwege te kleine aantallen geen nader onderscheid gemaakt worden naar zorg voor thulswonende kinderen.

Bif de vergelijking naar gelang werksituatie zal er vanult gegaan worden, dat bij een andere werksituatie dan werkend of hulsvrouw er sprake is van een minder gestruktureerd dagelijks leven. Het felt dat hier -anders dan b1f de vorming van de variabele strukturering van het dagel1 jks levenhuisvrouwen en 'werkenden' worden samengenomen, is Ingegeven door de onstandigheid dat er te weinig buitenshuis werkende vrouwen ziljn.

BIf gezinssituatie zal er vanult gegaan worden dat bil gehuwden met thuiswonende kdnderen het dagelijks leven sterker gestruktureerd is dan bij de andere gezinssituaties. 
In b1jlage I is in schema I aangegeven hoe de analyses $z 1, j n$ uitgevoerd.

Hierbly wll ik slechts twee van de vele beslissingen vermelden:

- b1j de analyse naar werksituatle is, met één ultzondering, de varlabele gezinssituatle als kontrolevariabele opgenomen. De uitzondering betreft de vergelijking van werkzoekenden en werkenden. Het aantal werkzoekenden liet niet toe nog een variabele in de analyse op te nemen.

- Bif de analyse naar gezinssituatie zifn de werkzoekenden, arbeldsongeschlkten en gepensioneerden ultgesloten.

Beide beslissingen zifn ingegeven door de wens interaktieeffekten tussen werk- en gezinssituatie onder kontrole te brengen dan wel uit te sluiten.

Werksituatie

Ik wil eerst de resultaten met betrekking tot verschillen naar gelang werksituatie bespreken.

Voor vrouwen $z 1 \mathrm{fn} e r$, in het ene geval dat de analyse kon worden ultgevoerd, geen verschillen in veel of weinig drinken te konstateren tussen werkzoekende en werkende (inkluslef hulsvrouwen) vrouwen in Iimburg, weshalve geen mult1plikatieve effekten berekend konden worden.

B1 f mannen zijn er wel verschillen in konsumptie naar gelang werksituatle. In Limburg en Rotterdam is b1 $\mathrm{j}$ werkzoekenden, vergeleken met werkenden, zowel de kans op veel drinken alsook de kans op wein1g drinken hoger. In Rotterdam wordt dit verband ook gevonden voor arbeldsongeschikte en gepensioneerde mannen. Bif arbeldsongeschikte mannen in Limburg is de kans op welnig drinken hoger en -in tegenstelling tot Rotterdam- de kans op veel drlnken klelner dan bij een vergell jkbare kategorle werkenden.

of bij arbeldsongeschikte mannen gezondheldsoverwegingen een belangrijke rol spelen bij drankgebrulk, kon voor LImburg worden nagegaan met behulp van partiele korrelaties. In Rotterdam is er, zoals uit de tabel is af te lezen, sprake van een kromlijnig verband tussen arbeldsongeschiktheid en konsumptlen1vo, waardoor nlet verder geanalyseerd kan worden met partiele korrelaties. In Limburg blijkt de korrelatle tussen arbeldsongeschiktheld en konsumptienivo nauwelifks te veranderen als wordt gekontroleerd op het oordeel over elgen gezondheld. De in vergelljking met werkenden grotere matigheld bif arbeldsongeschikte mannen in Limburg kan derhalve 
niet verklaard worden doordat arbeidsongeschikten hun gezondheld negatiever becordelen.

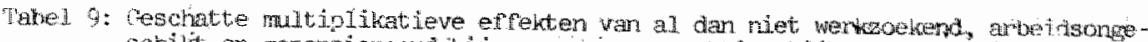

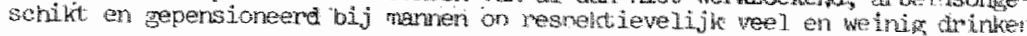

\section{LMBURG}

< 1 glas per week vis. $1-28$ gllaren per week
Konst ante

werkzoekend

weritrend

16-29 jaar

30 jaar en owder

\subsection{3}

1.. 7

0.58

0.91

1. 2
- 28 mlazer pen week vis. 1-28 glazen po: week

0.42

1.3

0.75

1. 4

$\begin{array}{lll}\text { Konstiante } & 0.23 & 0.12 \\ \text { arbeidsongeschikt } & 1.67 & 0.59 \\ \text { Werkend } & 0.60 & 1.70\end{array}$

ROTYERDAM

$\begin{array}{lcc}\text { konstante } & 1.1 & 0.78 \\ \text { werkzokend } & 1.7 & 2.4 \\ \text { werkend } & 0.6 & 0.42 \\ 16-29 \text { jaam } & x & x \\ 30 \text { javar en ouder } & x & x\end{array}$

\section{konstante}

arbeidsongeschikt

werthend

nongtamte

gepers lioneer

werkend
0.44

1.6

0.63

0.33

1.5

0.66
0.36

1.9

0.52

0.25

2. 4

0.42

Terzljde wll ik hier opmerken dat het nut van logit-analyse ook biljkt uit het felt dat Garretsen (1983) in een door hem ultgevoerde multiple regressieanalyse op de gegevens van Rotterdam, niet aan kon tonen dat onvrijwillige werkloosheid (arbeldsongeschikt, werkzoekend/anders) van invloed was op konsumptientvo. Blijkens de hier gepresenteerde resultaten is er bij werkzoekende en arbeidsongeschikte mannen in Rot- 
Tabe 10: Geachate multiplikatieve effekter van familie-

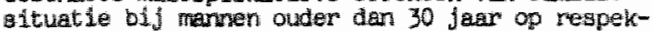
wheweiljk veel en weling drinkem

\section{LIMBUAC}

* 1 glas per weok ws. $>28 \mathrm{gl}$. per week va. 1-28 glazen per wek 1-28 gl. per wegk

\begin{tabular}{|c|c|c|}
\hline 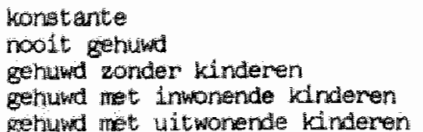 & $\begin{array}{l}0.18 \\
2.6 \\
0.59 \\
0.69 \\
0.94\end{array}$ & $\begin{array}{l}0.21 \\
2.2 \\
1.8 \\
0.96 \\
0.27\end{array}$ \\
\hline
\end{tabular}

\section{ROTTFODAM}

< 1 glas per week vs. >21 gl. per week vs. 1-21 glazen per week 1-21 glazen per week

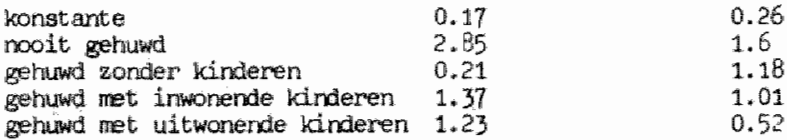

Gesohat m mitiplikatieve effekten wan familiesituat le bij vrowwen ouder diar 30 jam op respekthevelijk veel en welnig arinken

\section{LIMBURG}

$<1$ glas per week vis. 1-14 glazen per week
0.76
1.6
1.2
0.52
0.78
0.79
1.6
0.37
0.99
1.0
$0.52^{2}$
0.65
3.1.0

$>14$ gl. par week vs * 1-14 glazen per week

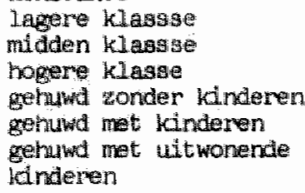

\section{ROITETLAM}

< 1 glas per week vs. $\quad>14 \mathrm{gl}$. per wek vs. 1-14 glazen per week 1-14 gitazen per week

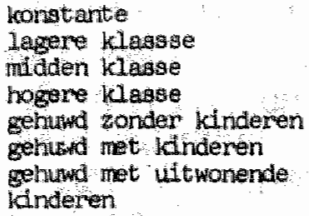
Ginderen 
terdam wel degelljk sprake van een verhoogde kans op veel drinken.

Een verschil tussen Rotterdam en LImburg wat betreft de Invloed van werksituatie bij mannen is te opvallend om niet vermeld te worden. In Rotterdam is het ontbreken van een arbeldsrol niet alleen sterker (zie werkzoekende mannen in Limburg en Rotterdam) maar ook vaker nameliffk óok bij arbeldsongeschikten en gepensioneerden) van invloed op intensivering van drankgebrulk dan in Limburg. In de diskussie zal op dit verschil tussen Limbung en Rotterdam nog worden teruggekomen.

Gezinssituatie

Bif mannen en vrouwen fonger dan 30 jaar is er noch in Limburg, noch in Rotterdam Invloed van de gezInssituatie op konsumptientvo aan te wijzen.

B1j mannen en vrouwen ouder dan 30 jaar is die invloed er blifkens tabel 10 wel. Bif mannen in Limburg blifkt bif noolt gehuwden en gehuwden zonder kinderen het veel drinken vaker voor te komen dan b1j gehuwden met ultwonende kinderen. In Rotterdam geldt dit alleen voor de noolt gehuwde mannen. B1.j noolt gehuwden mannen in Rotterdam is ook sprake van een vergelifkenderwijs hogere kans op weinig drinken. Helaas kunnen hier voor gescheidenen en weduwnaars geen ultspraken worden gedaan, vanwege te kleine aantallen.

De zorg voor thulswonende kinderen heeft bij mannen blijkbaar geen eendu1dige invloed op konsumptientvo. In LImburg is bif mannen zonder (thuis- of buitenshuiswonende) kinderen de kans op veel drinken hoger. Wonen de kdnderen buitenshuis, dan is er zowel bif mannen in Limburg als in Rotterdam sprake van een lagere kans op veel drinken en een hogere kans op weinlg drinken.

B1f vrouwen in Rotterdam zijn er geen verschillen in konsumptle naargelang gezinssituatie. In Limburg zifn die er wel: b1f gehuwde vrouwen met buitenshuis wonende kinderen is sprake van een verhoogde kans op veel drinken én een verhoogde kans op weinig drinken.

Overlgens is dit de enige keer dat er voor vrouwen een verschil wordt gevonden voor een indikator voor een minder gestruktureerd dagel1jks leven. Deze steun voor de hypothese betreffende de invloed van een weinig gestruktureerd dage- 
lijks leven, moet onvoldoende worden geacht om de hypothese voor vrouwen onveranderd te handhaven. In de diskussle zal hilerop worden teruggekomen.

Ten aanzien van het drankgebmuk van gehuwde vrouwen met bultenshuls wonende kinderen in Limburg kan nog een relevant detal1 vermeld worden. In het rapport over probleemdrinken in Limburg (Knibbe, 1982) werd gemeld, dat er op weekenddagen geen versch11 in alkoholkonsumptie is tussen gehuwde vrouwen met thuis- dan wel bultenshuls wonende k1nderen. Op doordeweekse dagen drinkt echter 13\% van de vrouwen met bu1tenshulswonende kinderen gemiddeld vier of meer glazen per dag, tegen slechts $4 \%$ van de vrouwen met thulswonende kinderen. De limburgse vrouwen zonder thulswonende kinderen zifn dan cok de enlge ultzondering op de regel dat op weekenddagen meer wordt gedronken dan op doordeweekse dagen.

VII. 4. Invloed van al dan niet dagonderw1 js volgen op konsumptientvo

U1tgesloten bij deze analyse zijn respondenten die opgaven:

- 30 jaar of ouder te z1Jn aangezien er bij degenen die 30 jaar of ouder $z 1 j n$, nauwelljks nog respondenten zijn die dagonderw $1 \mathrm{~s}$ volgen

- In een andere gezinssituatie te verkeren dan 'noolt gehuwd', ook hler ondat bij een andere gezinssituatie dan noolt gehuwd niet of nauwel1jks respondenten voorkomen dle opgaven dagonderwl js te volgen

- gepensioneerd, werkzoekend of arbeldsongeschikt te zijn, omdat $1 \mathrm{k}$ wllde vergel1Jken met werkenden.

De volgende varlabelen $z 1 \mathrm{Jn}$ in de analyse opgenomen: soclale klasse (laag, midden, hoog), dagonderwl Jsvolgend ( Ja/nee) en, als afthankel1jke varlabele, alkoholkonsumptlenivo (kategorleën verschillen naar gelang geslacht en reg10; zle de hlema te presenteren tabel). 


\section{Mannen}

Een model warin een direkte relatie tussen alkoholkonsumptie en al dan niet dagonderwljs volgen werd verondersteld bleek, vergeleken met andere modellen, tot een signifikant betere ordening van drinkers naar konsumptienivo te lelden. In tabel 11 zifn de multiplikatieve effekten weergegeven.

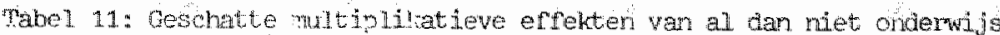
wolgem bij mannen op respektievelj.jk veel en weinig doinken

konstante degondierwis werkend

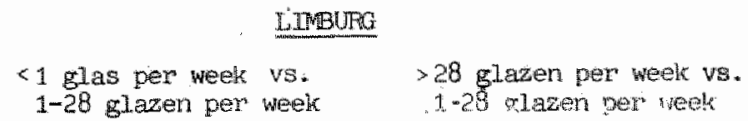

1 glas per week vs.
$1-28$ clazen per week

0.16

1.30

0.77

0.34

0.63

1.60

\section{FCTPERDAM}

< 1 glas per week vs.

1-21 glazen per week
$>21$ plazen per weok vs. 1-21 plazen per. week konstante
Aagonderwi.js
werkend

\subsection{9 \\ 1.30}

0.80
0.31

0.62

1.6

Het blijkt dat zowel in Limburg als Rotterdam b1j mannen die dagonderwI'ls volgen de kans hoger is dat ze tot de weinig drInkers behoren en de kans klelner dat ze tot de veel drInkers behoren. Korton werkende jongere mannen drinken meer dan Jongere mannen die dagonderw1.js volgen. Dit versch1l in intensiteit van drankgebruik tussen werkenden en "studerenden", kan nlet worden toegeschreven aan verschillen in burgerlifke staat, aangezien alleen noolt gehuwden in de anaIyse z1.Jn opgenomen.

Wellicht dat er naar gelang type onderw1 fs nog verschil is in intensitelt van drankgebrulk. $\mathrm{Er}$ zljn ultspraken gedaan dat op universitelten van intensief drankgebrulk sprake is, (van Rooyen, 1981; Janssen en Voestermans, 1978). Vergel1j- 
king met werkenden worden in deze studles echter niet gemaakt.

Overlgens kan men zlch afvragen of het felt dat werkenden meer drinken welllcht veroorzaakt wordt door de gemiddeld oudere leeft1Jd van de werkenden dan wel door het felt dat werkenden over meer geld beschlkken dan degenen die dagonderwljs volgen. Aangezien er geen sprake is van een kroml1 jnig verband, kan dit met behulp van partielle korrelaties, verder geanalyseerd worden.

Worden de partiële korrelaties berekend tussen al dan niet dagonderwi js volgen en konsumptientvo met kontrole op leeft1jd dan bl1jkt er in Rotterdam geen signiflkant verband meer te z1.jn (part. korr.: 0.09; $\mathrm{p}<0.05$ ), in Limburg bl1jkt daarentegen, $\infty \mathrm{k}$ na kontrole op leeft1jd, het verband slgniflkant te ziln (part. korr.: $0.22 ; \mathrm{p}<0.05$ ). In Rotterdam is het derhalve de gemiddeld oudere leeftifd van werkenden waardoor deze meer drinken. In Limburg is het waarschifnlifk het felt dat werkenden over meer geld beschikken waardoor hum konsumptientvo hoger 1 s.

\section{Vrouwen}

Noch In Rotterdam, noch in Limburg bleek, na kontrole op interaktle tussen soclale klasse en onderwljs, onderwljs van Invloed te zijn op konsumptienivo. Er zijn derhalve geen verschillen tussen werkende vrouwen en vrouwen die dagonderwljs volgen in intensiteit van drankgebruik.

VII. 5. Gemeentegrootte

De relatle tussen konsumptlentvo en gemeentegrootte kan alleen voor Llmburg worden geanalyseerd. Hler zal gebrulk gemaakt worden van partielle korrelatles en gekontroleerd worden op leeft1ja en soclale klasse.

op grond van inspektle van een krulstabel van gemeentegrootte met konsumptle, waren geen kromlljnige verbanden te verwachten, weshalve de partiele korrelaties goed geInterpreteerd kunnen worden. 
Bif de indeling van geneenten naar urbanisatlegraad is gebruik gemaakt van de C.B.S.-Indeling van gemeenten en wel op de volgende wijze:

- tot de kleine gemeenten werden die gemeenten gerekend waar in de hoofdkem maximaal 5.000 mensen woonden (C.B.S.-indeling, kategorieèn A1, $\mathrm{A} 2, \mathrm{~A} 3, \mathrm{~A} 4$ en $\mathrm{B} 1$ );

- tot de middelgrote gemeenten worden gemeenten gerekend met 5.000 tot 30.000 inwoners (C. B. S. -indeling B2, B3, $\mathrm{Cl}$ en $\mathrm{C2}$, met ultzondering van weert en Venray, belde gemeenten met meer dan 30.000 inwoners);

- tot de steden werden gerekend gemeenten met meer dan 30.000 inwoners.

Bif vrouwen in Limburg is er geen signifikante partiële korrelatie tussen gemeentegrootte en konsumptle. Bij mannen wel, namelijk een partielle korrelatie van $-0.06(p<0.05)$. Dit betekent dat er ofwel geen verband is tussen gemeentegrootte en konsumptientvo (vrouwen) ofwel het verband is tegengesteld aan de hypothese. Mannen uit kleinere gemeenten blijken namelijk een hoger konsumptientvo te hebben. De hypothese moet worden verworpen.

Ondanks de lage partiele korrelatle bij mannen, blijken er bif een break-down analyse, waarin gemiddeld konsumptienivo naar leeftijd (Jonger dan 30 jaar en 30 jaar en ouder) en urbanisattegraad wordt weergegeven, forse verschillen in konsumptle te $z 1 \mathrm{jn}$.

Bif jongere mannen woonachtig in kleine en middelgrote gemeenten is de gemiddelde weekkonsumptle respektlevelijk 23.8 en 25.6 glazen tegen 15.8 glazen b1y Jongeren uft de steden. B1 if mannen ouder dan 30 jaar is het verschtl naar gelang gemeentegrootte (nlet meer dan 1 glas per week) te verwaarlozen.

Het In kleine of middelgrote gemeenten minder gevariëerde aanbod aan vrijetifdsbesteding voor jongeren, is wellicht mede corzaak van het hoge konsumptlenivo. Al dan niet in kombinatie daarmee, $k a n$ een in hoofdstuk III geopperde mogelifkheid een rol spelen: in kleine en middelgrote gemeenten leven onder Jongeren normen die eerder aanzetten tot konsumptle, dan nomen die gerlcht $\mathrm{z} 1 \mathrm{Jn}$ op het beperken van drankgebruik dat gepaard gaat met nadelige gevolgen. Anders gezegd: drankgebrulk behoort op het (verstedelljkt) platteland mogelljk sterker tot de statusrol van de jong volwassen man dan in de grote steden. 
Samenvatting/diskussle

In onderstaand schema $\mathrm{z} 1 \mathrm{fn}$ de voornaamste uftkomsten weergegeven en tevens de konselwenties voor de hypothesen.

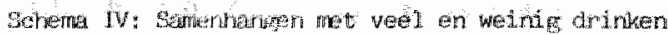

\section{WETTC DRTNEN

$\frac{\text { LIPBUFG }}{\text { Whon WTOWW man wouW }}$

WEWT DRTNGE

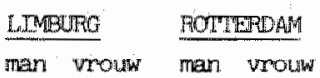

HYPOHTHEst:

man mout

struktumering dage $1 j j k$ bestar

(welnis - weel)

gerneentegroottie (klein - groot)

$-0 \quad-\infty$

bou bev.

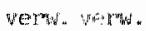

degoratemitis

werlozoekend:

arbidsongeserikt.

geperis lonerd

$\vdots$
$\vdots$
$\vdots$

$x \quad x$

$-0$

+0
$+\quad x$
$+\quad x$
$+\quad x$

$\begin{array}{cccc}- & 0 & + & 0 \\ + & 0 & + & x \\ - & x & + & x \\ 0 & x & + & x\end{array}$

Jonger dan 30 jagr

nooit gethud

gethut zonden kinderen

$\begin{array}{llll}0 & 0 & 0 & 0 \\ 0 & 0 & 0 & 0\end{array}$

$\begin{array}{llll}0 & 0 & 0 & 0 \\ 0 & 0 & 0 & 0\end{array}$

qualer dan 30 jaax

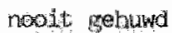

gesonolden

werwedund

gehuwd gorder kinderen

fehilwd met buitershuiswonende

idruteren

* : hogere kans

- : lagere kans

o : geen verschíl

* i nuet getratysert

Ik wil de diskussle beginnen met de bespreking van het versch11 tussen mannen en vrouwen. Voor mannen worden in vrljwel alle analyses relevante verschlllen in konsumptientvo gevonden. Voor vrouwen slechts 1 keer en alleen in Limburg: gehuwde vrouwen met buitenshuls wonende kinderen drinken intenslever dan gehuwde vrouwen met thulswonende kinderen.

Dat statusgroeperingen die versch1llen in drinkpatroon ook kunnen verschilien in of bepaalde faktoren van invloed $\mathrm{z} 1 \mathrm{jn}$ op konsumptlent vo dan wel in de mate van deze Invloed, daarop werd zowel in de inlelding van dit hoofdstuk alsmede in hoofdstuk III gewezen.

Mede naar aanlelding van het voorgaande hoofdstuk kan gekon- 
kludeerd worden dat bif vrouwen drankgebruik een veel minder sterk benadrukt gedragselement van de statusrol is dan blf marnen. Daardoor zullen vrouwen intensivering van drankgebruik veel minder vaak als adekwate en/of voordehand liggende reaktie zlen. De duidelijke verschillen tussen mannen en vrouwen die ult de analyse blifken, zljn aanlelding voor de volgende nleuwe hypothese:

Voorzover voor vrowwen in sterke mate de statusrolverlachting van incidenteel matig drankgebruik geldt, zijn er slechts weinig faktoren van invloed op intensivering wan drankgebruik bij vrowen.

Ik wil me hierna beperken tot het besprehen van de uitkomsten bij mannen en begirinen met verschilien in konsumptie tussen degenen die dagonderwlys volgen en degenen die werken.

Mannen die dagonderwljs volgen blifken minder te drinken dan mannen die werken, een uitkomst die nlet toegeschreven kan worden aan verschllien in burgerl1jke staat, aangezlen in de analyse alleen de nooit gehuwden zi.jn opgenomen.

Blf nadere analyse bleek dat in Limburg mannen die dagonderwljs volgen waarschijnilfk minder drinken omdat ze minder geld hebben dan werkenden. In Rotterdam is het de gemiddeld jongere leeft1 jd van degenen die dagonderwljs volgen waardoor ze minder drinken dan werkenden. Naar ik aanneen. is dit verschil tussen Limburg en Rotterdam een gevolg van de in Limburg veel sterkere nadruk op drankgebruik als st1jlelement in de statusrol van fong volwassen man. Daardoor speelt de beschlkbaarheld over drank -in termen van geld - een belangrijke rol. In Rotterdam daarentegen 11 jken er, ook blj mannen jonger dan 30 Jaar, relevante verschillen te bestaan tussen leeft1 Jdsgroepen in de mate waarln drankgebrulk een gelntegreerd onderdeel is van de statusrol van jong volwassene.

De invloed van de stmukturering van het dagel1 jks leven is bif mannen in Iimburg en Rotterdam volgens verwachting: bif een minder gestruktureerd dagel1jks leven treedt intensivering van drankgebruik op. Fen waardevol bifkomstig resultaat van de analyse is, dat bif een weinig gestruktureerd dage$11 j k s$ leven tegelijkert1jd óók een tendens tot minimal1sering van drankgebrulk te konstateren 1s. B1 f mijn weten is een dergelijke tendens nog niet eerder gerapporteerd. De aanwezigheid van deze twee tegengestelde tendensen wijst 
op een in de betreffende groeperingen levend besef aangaande de risiko's van drankgebrulk. Nieuw onderzoek bily mannen met een welnig gestmuktureerd dagelijks leven naar de faktoren waarin degenen die een vergelijkenderwijs matig drankgebrulk kennen, zich onderschelden van degenene die intenslef drinken, lifkt me ufterst relevant. Zowel om theoretlese redenen alsook omdat het brulkbare aanwifzingen kan geven voor vroegtifalge herkenning en preventie van probleemdrinken in deze groepering.

Nadere analyse van de invloed van strukturering van het dagel1jks bestaan bracht twee zaken aan het licht waarop ik h1er dieper w1l ingaan: de samenhang van zorg voor thulswonende kinderen met intensivering van drankgebruik en het verschil tussen Limburg en Rotterdam in de mate waarin het ontbreken van een arbeidsrol leidt tot intensivering van drankgebruik.

om met het eerst genoemde punt te beginnen: gesteld moet worden dat de afwezigheld van zorg voor thulswonende kInderen niet éénduldig samenhangt met het konsumptienivo voor mannen. Betreft het een gezinssituatle waarin de kinderen buitenshuis wonen, dan geldt voor mannen in Limburg en Rotterdam dat er, vergeleken met mannen met thuiswonende kinderen sprake is van een lagere kans op veel drinken. In Limburg, echter niet in Rotterdam, wordt gevonden dat bij gehuwde mannen zonder (thuis- of bul tenshuiswonende) kinderen de kans op veel drinken hoger is dan bif mannen met thuiswonende kinderen. Gezien deze uitkomsten, is de vraag naar de konditles waaronder bif mannen zorg voor thuiswonende kinderen van invioed is op de strukturering van het dagelljks leven, gerechtvaardigd. Vooralsnog echter zal in de volgende hoofdstukken zorg voor thuiswonende kinderen als indikator voor een weinlg gestruktureerd dagelijks leven gehandhaafd worden. Wel zal steeds grepoogd worden door nadere analyse aan te geven of er bif het ontbreken van zorg voor thuiswonende kinderen sprake is van de verwachte Invloed.

Dat in LImburg gehuwde mannen zonder kinderen een vergell $\mathrm{j}$ kenderw1js intenslef drankgebrulk kennen, in Rotterdam echter niet, is naar $1 \mathrm{k}$ vermoed het gevolg van het verschil tussen Limburg en Rotterdam in de mate waartn drankgebrut $\mathrm{k}$ een benadrukt en geintegreerd element in de statusrol van jong volwassenen man 1 s.

Voor Limburg kan, getulge het vorlge hoofdstuk, gesteld worden dat drankgebrulk een gemeenschappel1 jk gewaardeerd 
stiflelement van de statusrol van jong volwassen mannen is. Vergeleken daarmee, is het drankgebmulk van jongere mannen in Rotterdam een minder duldelijk en benadrukt element in de statusrol van jong volwassen man.

Ik acht het derhalve waarschljnlljk dat jongere mannen in Limburg een goede reden moeten hebben -zoals de zorg voor thuiswonende kinderen- om hun drankgebrulk te matigen. In Rotterdam daarentegen is de afwezlgheld van zorg voor thuiswonende kinderen blj jongere gehuwde mannen, geen aanlelding voor een vergelijkenderwijs intensief drankgebruik.

Het tweede punt waar ik op in w1l gaan betreft het verschil In de mate warin bif mannen in Rotterdam en Limburg het ontbreken van een arbeldsrol tot intenslvering van drankgebrulk leidt. In Limburg wordt namelijk alleen voor de werkzoekende mannen het verwachte verschil in veel drinken met werkenden gevonden. In Rotterdam voor werkzoekenden, arbeldsongeschikten en gepensioneerden.

Als eerste vraag kont hierbij op of zich eenzelfde verschil voordoet bif het ontbreken van een partner. Voor de oudere nooit gehuwde mannen, waarvoor zowel in Limburg als in Rotterdam werd vastgesteld dat deze vergelifkenderwi js intenslef drinken, blijkt dat in Limburg de tendens tot intensivering sterker is dan in Rotterdam. Deze ene bevinding laat echter niet toe uit te sluiten dat in Rotterdam het ontbreken van een pertner vaker -namel $1 j k$ ook bif weduwnaars en gescheldenen- van invioed is op het intensiveren van drankgebruik.

Doordat niet uitgesloten kan worden dat het verschil tussen Limburg en Rotterdam zowel het ontbreken van een arbeldsrol alsook het ontbreken van een partner betreft, kunnen er twee hypothesen ter verklaring van het versch11 worden geformuleerd:

Naar gelang drankgebmik een sterker geintegreerd element is in de statusmol van mannen, zal het ontbreken van een arbeidsrol of partner minder van invloed aijn op de mate warin het drankgebruik wordt geintensiveerd.

Naar gezang in een kuztuur arbeid tot de sterk benadrukte waarden behoort, zal bij het ontbreken van een arbeidsrol vaker de tendens aanwerig aijn het drankgebmik te intensiveren. 
Wordt zonder meer ultgegaan van de resultaten van de analyse, dan kan de tweede hypothese het meest aannemeli jk worden geacht.

Lumburg kan namel1jk getypeerd worden als een dominant katholleke reg10, gezlen het felt dat $90 \%$ van de respondenten zlch rekent tot de katholleke kerk. Voor Rotterdam is er geen godsdienstlge of levensbeschouwelljke groepering die in dezelfde mate domineert. Meer dan de helft van de respondenten $-56.2 \%$ van de respondenten- geeft op niet tot een kerk of levensbeschouwell jke groepering te behoren, daarna vormen degenen dle zich tot één van de protestantse kerken rekenen $-27 \%$ - de grootste groepering.

Mifn vermoeden is echter dat velen die thans tot de onkerke11 jken worden gerekend, ouders hebben gehad die tot éen van de protestantse kerken hebben behoort. Voorzover een waardenpatroon minder snel veranderd dan de formele particlpatie aan het kerkel1,k leven, kan aan Rotterdam nog steeds met enlig recht een (gesekularlseerd) kalvinisties arbeldsethos worden toegeschreven. Volgens Weber (1947) is éen van de karakteristleken van het kalvinisties arbeldsethos dat werk sterk benadrukt wordt als zingevend principe. Op grond hiervan is te verwachten, dat in Rotterdam het wegvallen van werk als een grotere aanslag op de mogelljkheden voor een betekenlsvol bestaan wondt ervaren dan in LImburg. Het is voorstelbaar dat hiendoor in Rotterdam, vergeleken met Limburg, het ontbreken van een arbeldsrol sterker en vaker leldt tot intensivering van drankgebrulk.

Gesteld echter dat ult nader onderzoek zou blifken dat in Rotterdam vaker dan in LImburg ook geschelden mannen en weduwhaars genelgd z1 In hum drankgebrulk te intensiveren, dan zou de eerste hypothese aamemel1jk worden. In het vorlge hoofdstuk bleek dat in Limburg drankgebrulk sterker geIntegreerd is in de statusrol yoor mannen.

De in Limburg duldellfker te achten aanwlyzingen in de statusrol hoe drankgebrulk als een betekenlsvol element in de leefwljze op te nemen, kan fulst mensen in relatlef kwetsbare posities, 1.c. zonder werk of zonder partner, er voor behoeden drankgebrulk te zlen als middel om spanningen te neutraliseren en/of te ontvluchten.

De integratie van drankgebrulk in het leefpatroon is tot nu toe vrljwel ultslultend aan de orde gesteld in de kontekst van de vraag of de mate van integratle van invloed is op de 
kans dat schadelijke gevolgen van drankgebmulk optreden ( $\mathrm{Ba}-$ con e.a., 1965; Bales, 1946; Skolnlck, 1958). Er is echter thans een zekere, op onderzoeksresultaten gebaseerde, konsensus dat nlet zozeer de mate van integratie van drankgebrulk van invloed is op de kans dat drankgebruik gepaard gaat met nadelige gevolgen, doch het gemiddelde konsumptienivo in een bevolking (Frankel, Whitehead, 1981). Een andere vraag is echter of de mate waarin er duldelijke statusrolverwachtingen omtrent drankgebruik bestaan, van invloed is op de genelgdheld van mensen met een weinig gestruktureerd dagel1jks leven hun drankgebruik te intenslveren. De hier gepresenteerde resultaten $z 1 j \mathrm{j}$ een aanwijzing dat deze mogel1.jkhe1d niet uitgesloten kan worden.

In Limburg bleken jonge mannen uit klelmere gemeenten een hoger konsumptientvo hebben dan jonge mannen uit gemeenten met meer dan 30.000 inwoners. Waarschijnljk is in de kle1nere gemeenten drankgebrutk een sterker benadmukt element in de statusrol van fong volwassen mannen dan in grotere gemeenten. Mogelijk is de in kleinere gemeenten sterkere nadruk op drankgebrulk als element van de statusrol van jong volwassene mede te wijten aan een, vergeleken met grotere steden, geringer aanbod aan vrijetijdsbesteding voor fong volwassenen. De nieuwe hypothese met betrekking tot urbanisatiegraad luidt als volgt:

In kininere gemeenten is drankgebruik een sterker

benadmikt element in de statusrol van jong volwassen mannen dan in steden (meex dan 30.000 inwoners). Dit leidt tot een gemiddeld hoger konsumptienivo bij jongere mannen woonachtig in kleine gemeenten.

Gezlen de uitkomsten die casselman e.a. (1983) presenteren, is een kanttekening b1j deze hypothese op zijn plaats. Casselman e.a. stellen vast dat in Belglè schoolgaande Jongeren ult Leuven en Gent minder drinken dan schoolgaande jongeren uit Brussel. Gent en Leuven zouden echter in de hler aangehouden typologle naar gemeentegrootte nog steeds onder de "steden" vallen. U1t bovengeformuleerde hypothese mogen dan ook niet zonder meer ultspraken afgeleld worden over verschillen in konsumptie naar urbanisatiegraad bij gemeenten met meer dan 30.000 inwoners. 
Nog twee punten wll ik kort bespreken on daama in een schema rogmaals aan te geven welke faktoren, inkluslef die welke in nleuwe hypothesen zijn vastgelegd, van invloed kumnen worden geacht op intenslvering van drankgebmulk.

Het eerste punt betreft de Invloed van gezondheidsoverwesingen op intensiverlng van drankgebrulk. Het tweede of er verschll 18 tussen degenen bij wle een maatschappelijk normaal geachte rol (werkzoekend, arbeidsongeschikt, geschelden en oudere noolt gehuwden) ontbreekt en degenen blf wle op een andere wljze stmuktuur in het dagelijks leven ontbreekt. (1.c. Jongere noolt gehuwden, weduwen/weduwnaars, geen zorg voor thulswonende kinderen).

Voor Limburg kon worden vastgesteld dat arbeldsongeschikten nilet vanwege een als slechter beoordeelde gezondheld minder drinken dan werkenden. Voor Rotterdam moest afgezien worden van nadere analyse naar de 1 nvloed van gezondheldsoverwegingen, omdat er sprake was van een kromlijnig verband.

Wel bleek bly arbeldsongeschikte mannen in Rotterdam het veeldrinken vaker voor te komen dan bij werkende mannen. Er zifn derhalve geen aanwlyzingen dat gezondheldsoverwegingen een matigende invloed hebben op het drankgebrulk van arbeidsongeschikten.

Wat betreft het tweede punt, kan er op gewezen worden dat bl I mannen bif het ontbreken van een maatschappe li fk nomaal geacht rol viff van de zes keer een samenhang met intensiverling van drankgebrulk wordt gevonden, namelifk bif werkzoekende en oudere noolt gehuwde mannen in Limburg en Rotterdam (4x) en arbeldsongeschikte mannen in Rotterdam. Waar op een maatschappel1Jk aanvaardbaarder w1jze alledaagse verplichtIngen ontbreken, wordt slechts twee van de acht keer een samenhang gevonden, namel1jk blj gepensioneerde mannen in Rotterdam en gehuwde mannen zonder kinderen in Limburg. De analyse laat derhalve de konklusle toe dat het ontbreken van een maatschappel1jk nomaal geachte rol sterker van invioed is op intensivering van drankgebrulk dan het ontbreken van alledaagse verpllchtingen om maatschappe l1 $\mathrm{jk}$ aanvaardbaarder reden. Wel moet opgemerkt worden dat weduwnaars en geschelden mannen niet in de analyse zi.nn opgenomen. 
In onderstaande figuur is weergegeven welke faktoren inkiuslef de nieuwe hypothesen, van invloed geacht kunnen worden op intensivering van drankgebrulk.

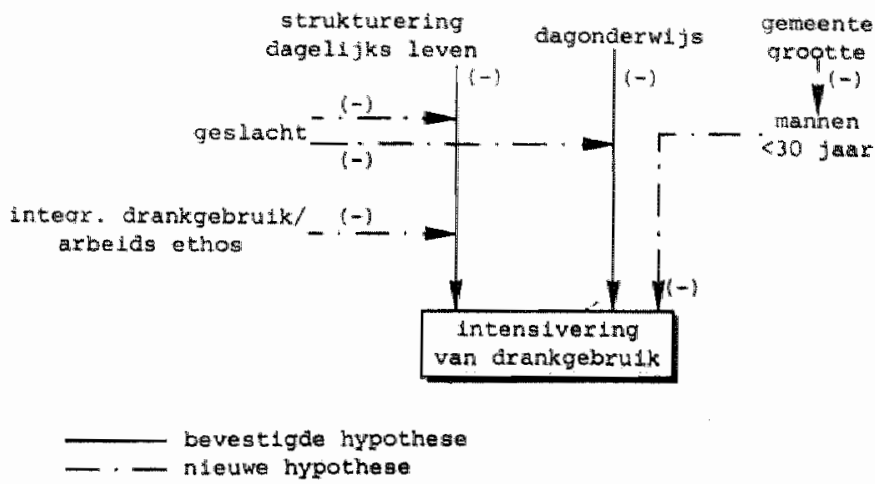

Wellicht ten overvloed zif vermeld dat de verschillen in konsumptientvo tussen statusgroeperingen niet in dit schema zif $\mathrm{fn}$ opgenomen ondat deze gezien kunnen worden als in een populatie 'nomaal' geachte verschillen in konsumptie en derhalve nlet geInterpreteerd dienen te worden als intens1vering van drankgebruik. 


\title{
VII Gangbaar drinkpatroon en nadelige gevolgen
}

\author{
van drankgebruik
}

\section{Inle1ding}

In dit hoofdstuk komen twee onderwerpen aan de orde:

- de operationalisering van nadelige gevolgen van drankgebruik

- de relatie van gangbaar drinkpatroon met respektlevelijk excesslef drankgebrulk en nadelige gevolgen van drankgebrutk.

Over dit laatste onderwerp zifn geen hypothesen geformuleerd. Wel is gesteld dat statusgroeperingen dle verschillen in gangbaar drinkpatroon kunnen verschillen in de mate wearin, b1 f overeenkamstig konsumptienivo, nadelige gevolgen van drankgebrulk optreden.

De analyse van de relatie tussen drinkpatronen op zlch - Ios van verschilien in drinkpatroon tussen statusgroeperingenmet excessief drankgebrutk en nadelige gevolgen van drankgebrulk is echter on twee redenen een aparte beschouwing waard: de achtergrond van de verwachte invloed van statusfaktoren op nadelige gevolgen wordt verhelderd en het is een vaak genoend, echter welnig onderzocht thema in de alkoholIlteraturus.

VIII. 1. Operationalisering van nadelige gevolgen van drank-

B1f de opzet van het Limburgs en Rotterdams onderzoek is dankbaar gebrulk gemaakt van de indikatoren die in bultenlands onderzoek worden gebrulkt voor 'drinkproblemen' (Cahalan, 1976; Knupfer, 1967; Mulford en Wilson, 1966; Saunders en Kershaw, 1978; Cartwright en Shaw, 1978b; Edwards e.a 1973), waarb1j het aksent heeft gelegen op de studie van Cahalan (1976).

In de rapporten over probleendrinken (Garretsen, 1982; KnIbbe, 1982) is uitgebreld aangegeven hoe de problemen rond 
drankgebrutk zljn geindlceerd. Wat in deze studle 'nadelige gevolgen" van drankgebrulk wordt genoemd, komt overeen met de volgende problemen in genoende regionale rapporten:

- psychologlese afhankel1 jkheid

- symptomen van drankgebrulk

- problemen met de gezondheld of ongelukiken

- dronkenschap en/of kater

Gezlen de uttgebreldheld waarmee in genoemde rapporten aangegeven is op welke wljze deze kategorieën van nadelige gevolgen geindlceerd zijn, wordt hler volstaan met een korte beschrijving.

De variabele psychologlese afhankeli jkheld bestaat uft zeven 1 terns.

Twee voorbeelden hlervan zifn 'drinken helpt me mifn zorgen te vergeten' en 'door een drankje kan $1 \mathrm{k}$ er beter tegen als $1 k$ eenzaam ben'. (b1j1. III, Invulform. AII, uitgezonderd de 1tems, 4,6,7,11). Deze voorbeelden kunnen duidelıjk maken dat psychologlese afthankelifkheld een indlkatle is voor de genelgdheld om door middel van drankgebrulk problemen op te lossen.

De skore op deze varlabele wordt berekend door een respondent één punt toe te kennen als een uitspraak beaamd werd als een 'beetje waar'. Twee punten worden gegeven als een respondent een bepaalde ultspraak ten volle beaamt ("helemaal waar'). De skore op deze variabele kan derhalve varlëren van 0 tot 14 punten.

Symptomen van drankgebrulk is een variabele die bestaat ult acht 1 tems.

Voorbeelden van deze Items zifn: "1k ben wel eens wakker geworden nadat $1 \mathrm{k}$ de dag ervoor gedronken had en $1 \mathrm{k}$ wlist nlet meer wat $1 k$ tijdens het drinken had gedaan'; '1k dronk wel eens stleken"; "1k had de ochtend nadat $1 k$ gedronken had trillende handen' (b1fl. III, invulform. III, items $2,3,4$, $5,7,8,9,10)$.

De skore op de varlabele symptomen werd berekend door na te gaan hoeveel van deze symptomen de respondent het laatste half jaar had ondervonden.

De skore kan derhalve oplopen van nul tot acht punten. 
De variabele problemen met de gezondheld en/of ongelukken vanwege drankgebrulk bestaat ult vier items.

Deze vier 1tems betroffen het oordeel van de respondent zelf over nadelige invloed van drankgebrulk op zi in gezondheld, het oordeel van een arts over nadelige invloed van drankgebrulk op de gezondheld, een opname in zlekenhuls of kliniek variwege drankgebrulk en een ongeval na te hebben gedronken (bifl III vr, 10B, vr. 29A, invulformulier III, $\mathrm{nr}, 16$ en 20)

Op deze varlabele wordt 1 punt toegekend als een respondent. - of wel beaamt een ongeval te hebben gehad na drankgebrulk, - of wel één of meer van de drie andere items over de rela tle van drankgebrulk en gezondheid beaamt.

Een skore van twee punten werd toegekend als een respondent zowel beaamde een ongeval te hebben gehad vanwege drankgebrulk én op ến of meer van de drie andere items positief skoorde.

De variabele dronkenschap/kater duidt op de frekwentle waarmee de respondent het afgelopen half jaar dronken is geweest en/of een kater heeft gehad. .

In principe kan de skore op deze variabele oplopen tot 365: ledere dag dronken en ledere dag een kater. De hoogste skore die in de steekproeven van Limburg en Rotterdam gehaald worden 1s 182, hetgeen b1 $j$ benadering inhoudt dat een respondent minstens 1 keer per dag dronken 1s of een kater heeft.

VII. 2. Relat1e van drinkpatroon met nadelige gevolgen van

In hoofdstuk II is al gewag gemaakt van de Ledermann-formule en van de meer recente varlant daarop, het zogeheten "single distribution model". Er werd toen één aspelt van de verdeling van drlnkers naar konsumptientvo naar voren gehaald, namelljk dat het grootste deel van de drinkers slechts we1nig meer of minder drinkt dan het gemiddeld konsumpienivo in de betreffende populatie.

Van het single distribution model ziln meerdere stellingen of te leiden. De bekendste is wellicht dat er een regelmatige relatie is tussen het gemiddeld konsumptienivo in een pom pulatie en de proportie excessieve drinkers (Ledermarm, 1964, Bruun e. a. 1975) 
Ondat voor de berekening van de proportie excessieve drinkers slechts één, vrıj gemakkel1jk te verkrıjgen, gegeven nodig is - de gemlddelde konsumptie per hoofd van de bevolking (te berekenen ult accijnscljfers en bevolkingsgegevens) - wordt de Ledemannformule vrij vaak gebruikt (Ledermam, 1964; de Iint en Schmidt, 1968; Popham, Schmidt, de Lint, 1975; Brum e. a. 1975; Wever, Gips, 1977).

Toch is het Ledermann single distribution model niet onomstreden.

De voornaamste diskussiepunten zijn of een andere dan de door Ledermann voorgesteld "lognomale verdeling" niet een betere 'fit' geeft (genoend is $0 . a$. de door gamma-verdeling, Skog 1979); of de door Ledermann voorspelde relatie tussen een st1jgend gemiddelde konsumptie in een populatie en de toename van excessieve drinkers zich in feite voordoet (Cartwright e.a., 1978 a,b; Fitzgerald, Mulford, 1981) en de aanname dat de kurve waarmee de verdeling van drinkers naar konsumptienivo wordt beschreven een kontinu verloop heeft. Dit laatste is in tegenspraak met de sinds Jellinek (1946) steeds sterker veld winnende gedachte dat 'alkohollsme' een zlekte is waarbif niet zozeer een gradueel als wel een fundamenteel verschll tussen 'gewone' drinkers en 'alkohol1sten' of 'probleemdrinkers' wordt verondersteld. (M1ller en Agnew, 1974; Edwards, 1977).

Bif alle diskussle over de brutkbaarheld van het Ledermannmodel zlin twee, mijns inziens belangrijke, aspekten niet of slechts zeer sumier onderzocht: de onderschatting van alko holkonsumptle met surveygegevens en het probleem van verschillende drinkpatronen.

Gegeven het felt dat met survey-gegevens 35\% tot $70 \%$ van de konsumptle zoals die utt (betrouwbaarder) accijns- of verkoopciffers bl1jkt, wordt onderschat (Pemanen, 1974; van Reek e.a. 1983), moeten bif leder model dat 1s ontwikkeld op grond van opgaven van individuen over hun drankgebrulk de nodige vraagtekens gezet worden.

op het tweede genoende punt, dat van de drinkpatronen, w11 ik hier ultgebrelder ingaan. Ledemarm zelf noemt dit probleem wel. Hif stelt dat de relatie tussen gemiddeld konsumptienivo en proportle excessleve drinkers slechts opgaat voor populaties met een relat1ef homogeen drinkpatroon. Ledermarn verzuimt echter dit punt ult te werken en uitgezonderd b1y Skog (1977) kont dit punt bif publikatles over de Ledermann-formule nauwel1jks naar voren. Een des te meer 
onbevredigende situatie als men de resultaten van de studie van Cartwright en Shaw (1978) in ogenschouw neent. ZIJ vonden dat bif een overeenkomstlg konsumptienivo bif jongeren en In de lagere soclale klasse de kans op nadelige gevolgen van drankgebrulk hoger waren dan bif respekt levelifk ouderen en in de hogere soclale klasse. En de verklaring daarvoor l1gt gedeeltel1Jk in het versch1l in drinkpatroon tussen genoemde groeperingen (zle hoofdstuk IV).

In hoofdstuk VI werd voor Limburg gevonden dat de drinkpatronen perlodiek veel drinken en bi Ina dagelijks thuis drinken niet slgnlflkant verschilden wat betreft de gemiddelde konsumptle per week, echter wel signifilcant verschilden wat betreft alle andere daar genoemde aspekten van drinkgedrag. Het felt dat in Limburg twee verschillende drinkpatronen voophanden zifn met een gelljke gemlddelde konsumptle, biedt de mogell.jkheid na te gaan welke invloed het drinkpatroon heeft op de relatie tussen gemiddeld konsumptienivo en de proportle drinkers in de hogere konsumptiekategorleën.

Met voorbl Jgaan aan de opmerking van Ledermann wordt hier als hypothese aangehouden de veronderstelling die in alle publikaties warin de Iedermann-formule wordt toegepast wordt aangehouden:

bngeacht het drinkpatroon is de proportie overmatige drinkers gelijk bij verzamelingen arinkers

met een gelijk gemiddeld konsumptienivo.

Het begrip "verzameling drinker's" is hier gebrulkt an te benadmukken dat uitsluitend op grond van drinkpatroon respondenten tot de ene dan wel andere verzameling worden gerekend, en niet op grond van statuskenmerken die samenhangen met drinkpatronen.

Voorzover het de hypothese betreft zal "ovematig" gedeflniëend worden in termen van gemiddeld aantal glazen per dag. Ter wille van de volledigheld zal ook nagegaan worden of er verschlllen $z 1 j n$ in het percentage dat weinlg drinkt (gemiddeld minder dan 2 glazen per dag) en in het percentage dat veel per keer arinkt.

Als de eerste hypothese bevestigd wordt, kan ook worden nagegaan of behalve het percentage xcessieve drinkers oók het drinkpatroon van invloed is op nadelige gevolgen. Als hypothese wordt aangehouden:

veramelingen drinkers die overeenkomen in de proportie overmatige drinkers, echter verschizzen in drinkpatroon, zullen verschillen in de mate warmin drankgebrutk leidt tot nadetige gevolgen. 
Deze hypothese 11gt elgenl1jk ten grondslag aan de in het volgende hoofdstuk te toetsen hypothese betreffende statusgroeperingen die mogel1 fk versch11len in de mate war $1 \mathrm{n}, \mathrm{b} 1 \mathrm{f}$ overeenkamstig konsumptlenlvo, drankgebrulk gepaard gaat met nadelige gevolgen.

U1t het Ledermann- of "single distribution model" zlin geen uitspraken af te leiden of, naast het percentage excessleve drinkers, ook het drinkpatroon van invloed is op de mate waarin drankgebrulk tot nadelige gevolgen leldt. Wel zijn belangrijke voorstanders van dit model, 1. c. Popham, Schmidt en de Lint (1975) van mening dat excesslef drankgebruik op zich een voldoende betrouwbare indikator is voor de mate waarin drankgebrulk gepaard gaat met nadelige gevolgen.

\section{3. Resultaten}

In tabel 12 is voor een aantal konsumptienlvo's en kategorleën nadelige gevolgen aangegeven hoe vaak deze bif perlodlek veel drinken en bijna dagel1jks thuis drinken voorkomen.

Zolang gekeken wordt naar de gemiddelde konsumptie per dag van vier, zes of acht glazen zlJn er geen slgniflkante verschillen tussen belde drinkpatronen. De wat mij betreft verrassende overeenkomst bij beide drinkpatronen in percentage drinkers in de hogere konsumptiekategorieèn, is een bevestiging van de eerder geformuleerde hypothese. Er is wel een signiflkant verschil in het percentage dat gemiddeld minder dan twee glazen per dag drinkt: bij periodiek veel drinken is dat percentage hoger $(46.4 \%)$ dan b1j b1jna dagel1jks thuls drinken (37. 4\%).

Wordt qekeken naar het percentage dat acht of meer glazen per keer drinkt, dan treedt er een beduldend verschil op tussen periodiek veel drinken en bijna dagelljks thuis drinken. Bijna 20\% van degenen die periodiek veel drinken, drinken acht of meer glazen per keer. Bif degenen die bijna dagelijks thuis drinken is dat minder dan een half procent. (zle cok tabel 4, in hoofdstuk VI). 


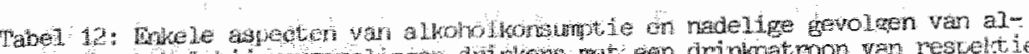

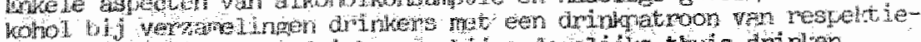

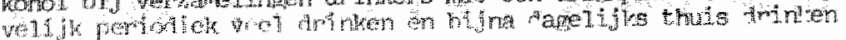

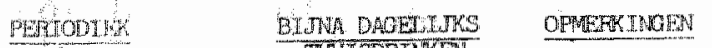 FUTISTRIMLTI}

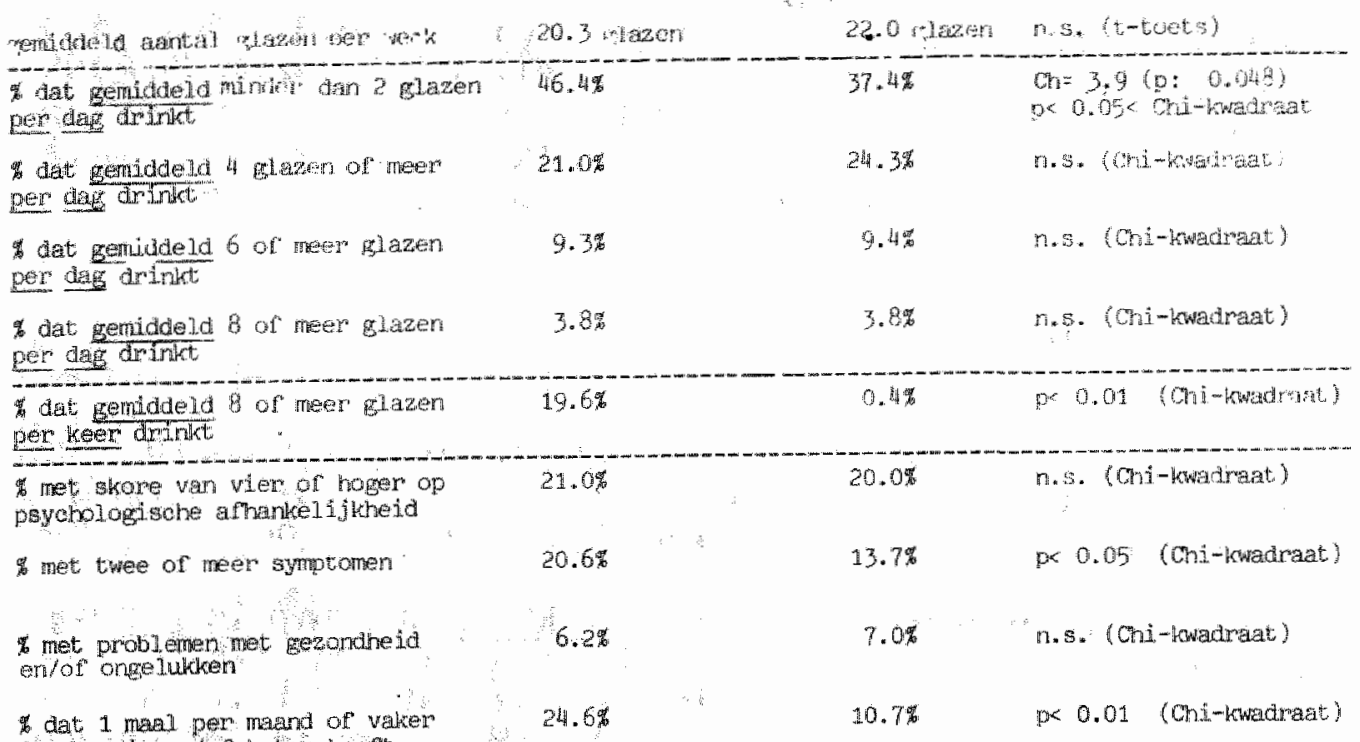

dromicun is en of kater hew

De veel hogere hoeveelheld per keer 1s, naar vermoed kan worden, de achtergrond van de signifikant hogere percentages drinkers met symptamen van drankgebrufk en dronkenschap/kater bif periodiek veel drinken. Ook de tweede hypothese hoeft nlet verworpen te worden.

Terzijde zij opgemerkt dat het hler gepresenteerde materiaal geen ondersteuning biedt voor de ult het "single distribution model" model af te leiden hypothese dat bij gelijk gemiddeld konsumptientvo de kurve waarmee de verdeling van drinkers naar konsumptlentvo wordt weergegeven gelijk is. Irmers, er is een signifikant verschil tussen beide drinkpatronen in het percentage dat gemiddeld twee glazen of minder per das drinkt.

Het belang van het drinkpatroon, met name de hoeveelheld per 
keer, betekent ook dat schattingen van de prevalentie van excesslef drankgebruik met behulp van het Ledermann-model, zeer onvolledige informatle geven over de mate waar In drankgebruik is geassociëerd met nadelige gevolgen. Voor het betoog van deze studle betekent voorgaande dat in Limburg te verwachten is dat, bif overeenkomstig konsumptienivo, bif Jongere mannen -van wie een meerderheld perlodiek veel drinkt- vaker symptomen van drankgebrulk en dronkenschap/ kater voorkomen dan bif oudere mannen. Aan onder andere dit onderwerp zal het volgende hoofdstuk zifn gewi jd. 


\section{Faktoren van invloed op nadelige gevolgen}

\section{I. Inlelding}

In hoofdstuk IV $1 \mathrm{~s}$ beargumenteerd dat, behalve konsumptienivo ook de volgende faktoren van invioed zijn op nadelige gevolgen van drankgebrulk:

- Statusfaktoren die samenhangen met verschillen in drinkpatroon, 1.c. geslacht, leeft 1 jd en soclale klasse

- Gewenning, geindiceerd door de duur waarmee het huldige aantal glazen per dag wordt gedronken

- de mate van strukturering van het dagelijks bestaan. In onderstaande figuur is binnen het omliynde gedeelte aangegeven welke samenhangen verwacht worden.

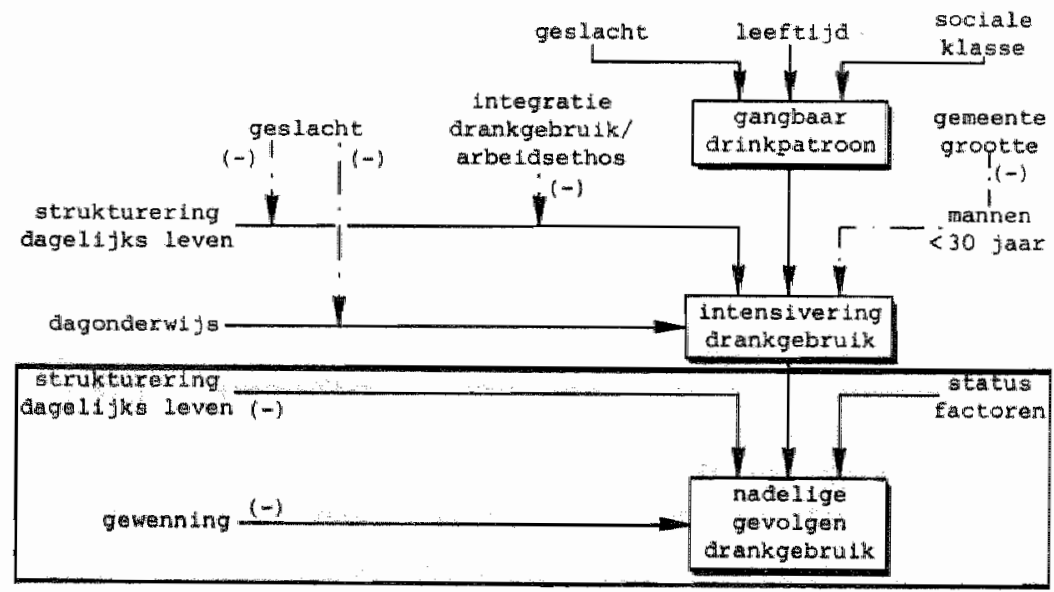

- bevestigde hypothese

- - mieuwio hypothese 
De hypothesen die in dit hoofdstuk getest zullen worden, lulden als volgt:
Statusgroeperingen die versonilzen in drinkpatroon kunnen, bij kontrole op konsumptienivo, verschillen in de mate waarin drankgebmik gepaard gaat met nadelige gevolgen. Bij grotere gewenning aan alkoholhoudende drank is, bij overeenkomstig konsumptienivo, de kans kleinex aat irank- gebruik leidt tot nadelige gevolgen.
Bij een minder gestmuktureerd dagelijks leven is, ook na kontrole op konsumptienimo, de kans op nadelige cenolgen groter.

De beschrifving van de verschillende kategorleën nadelige gevolgen is in het vorlge hoofdstuk al gegeven. In de belangrlfkste analyse zullen de vler kategorleën nadelige gevolgen worden samengenomen tot éën afhankel1jke variabele: de Index voor nadelige gevolgen.

Deze index voor nadelige gevolgen van drankgebrulk is, het zif bij voorbaat gezegd, niet vergelljkbaar met de 'probleemindex' zoals die door Garretsen en Knibbe in eerdere publikaties is gebrutkt (Garretsen, 1982, 1983, Knibbe, 1982).

De voomaamste verschillen zijn dat in de hier te gebruiken Index 'problemen met de omgeving' niet zijn opgenomen. Het overgrote deel van de items betreffende problemen met de omgeving betreft zorgen over of kritiek op drankgebrulk. Hieraan is in deze studie een aparte probleemstelling gewl jd. Tevens is bif de konstruktie van de probleemindex van Garretsen en Knibbe een drempel aangehouden (bv. met één symptoom werd er nog geen punt op de probleemindex van Garretsen en Knlbbe toegekend) om aan zekerheld te winnen dat, als een respondent skoorde op de probleemindex, het on substantiele problemen ging. Hier zal geen drempel worden aangehouden. Uitgangspunten bij de konstruktie van de hier te gebruiken index is, dat alle meldingen van nadelige gevolgen (zle voorgaand hoofdstuk) tot uttdrukking komen in de skore op de te vormen Index voor nadelige gevolgen van drankgebrulk. Tevens dat elk van de vier onderschelden soorten nadellge gevolgen even zwaar telt b1j de toekenning van punten op de Index van nadellge gevolgen.

In de bljlage III is aangegeven hoe de index is gekonstrueerd.

Hier wil $1 \mathrm{k}$ volstaan met op te merken dat ledere kategorle 
nadelige gevolgen maximaal vier punten kon bijdragen aan de Index. De skore op deze index kan derhalve in princlpe varieren van 0 tot 16 punten. In de bljlage (tabel 5) zifn de frekwentleverdelingen van Limburg en Rotterdam weergegeven.

De statistiese analysetechniek die in dit hoofdstuk gebruikt zal worden is anova (SPSS manual, 1975). Deze techniek laat toe te kontroleren op varlabelen die van invloed $\mathrm{z} \mathbb{1} j \mathrm{j}$ op de athankel1jke varlabele, maar waarover men geen uitspraken w1l doen. In alle hlerma te presenteren analysen is dit de varlabele konsumptienivo, die als zogeheten kovariant is ingevoerd. Waar relevant en mogelljk $\mathrm{z} 1 \mathrm{jn}$ ook andere varlabelen ter kontrole als kovariant in de analyse ingevoerd. Anova heeft als voordeel dat aan de onafhankelljke varlabelen (faktoren) geen voorwaarden gesteld hoeven te worden wat betreft meetnivo. Anders gezegd: het mogen nominale variabelen zijn.

Voor de analyse van varlantle in skore op de index kunnen de F-waarden de belangrifkste uitkomsten worden geacht, omdat aan de hand daarvan is aan te geven of er sprake is van signiflkante verschilien. Een andere serle ultkomsten, die van de zogeheten 'Multiple Classification Analysis', maken het mogelijk de richting van de invloed van de onafhankelijke varlabele op de afthankelifke varlabele aan te geven. De "multiple classification analysis" geeft namelijk de geschatte skore op de index als wordt gekontroleerd op de andere in de analyse opgenomen variabelen (zowel faktoren als kovartanten).

Hier is gekozen voor een varlant van anova waarbif de F-waarden berekend worden met kontrole op alle andere in de analyse opgenomen variabelen. $\mathrm{Om}$ een voorbeeld te geven: wordt de Invloed van geslacht op de skore van de Index nagegaan en konsumptienivo als kovarlant ingevoerd, dan wordt de F-waarde voor geslacht berekend met kontrole op konsumptie en de F-waarde voor konsumptie met kontrole op geslacht. (optle 7 van spss, 1975).

De analyses die betrekking hebben op het toetsen van de hypothesen, zijn in twee varianten uitgevoerd. De belangrifkste analyse acht 1k die waarin de Index voor nadelige gevolgen de afhankelifke vartabele is. Deze zullen in de hiema volgende paragraaf gepresenteerd worden. Dezelfde analyse is echter on twee redenen ook uitgevoerd met de afzonderlijke 
kategorleën nadelige gevolgen als afhankelljke variabelen:

- on relevante verschillen in de skore op één van de kategorleën nadelige gevolgen op het spoor te komen die niet terug te vinden zijn in de skore op de Index.

- on te kunnen aangeven ten aanzien van welke specifleke soorten nade 11ge gevolgen de in de hypothese genoemde faktoren het sterkst van invloed zijn.

De resultaten van deze analyse zl.jn in de biflage (schema

II) opgenomen.

In paragraaf IX. 3. volgen analyses met betrekking tot twee meer specifleke vragen:

- dragen de drie indikatoren voor een weinig gestruktureerd dagelijks leven in gelljke mate bij aan een hogere kans op nadelige gevolgen?

- Is de kwetsbaarheld voor nadellge gevolgen van drankgebruik groter bij het ontbreken van een maatschappelijk normaal geachte rol (bv. gescheldenen, werkzoekenden) dan bif anderen met een weinig gestruktureerd dagelifks leven (bv. Jongere noolt gehuwden, of gepensioneerden)?

IX. 2.1. Invloed van statusfaktoren op de skore op de index

In de hypothese over de invloed van statusfaktoren wordt niet aangegeven welke verschillen er verwacht worden tussen statusgroeperingen. Gegeven de beschrijving van drinkpatronen en de statuskemmerken die samenhangen met verschillen in drinkpatroon in hoofdstuk VI, is het ook nu pas mogelijk de algemene hypothese nader te specificeren. Bly leder statuskermerk zal dan ook eerst worden aangegeven welke samenhang verwacht wordt met de skore op de Index.

Leldraad bif de formulering van deze verwachtingen ziln de uitkomsten van hoofdstuk VII. Daar werd gekonstateerd dat de hoeveelheld die per keer wordt gedronken van invloed is op de mate waarin bif overeenkomstig konsumptienivo symptomen van drankgebruik en dronkenschap/kater voorkomen. Hier zal, analoog aan deze bevinding, als vulstregel worden aangehouden dat, b1f overeenkomstig konsumptienivo, de hoeveelheld dle per keer wordt gedronken van invloed ls op de skore op de index voor nadelige gevolgen.

In sommige gevallen kan er overigens aan getwijfeld worden of de hoeveelheld die per keer wordt gedronken dan wel een 
ander, met drinkpatroon samenhangend gegeven, de belangr $1 \mathrm{jk-}$ ste oorzaak is voor een hogere skore op de index. B1jvoorbeeld, een konsumptie van zes glazen kan, Indien thuls gedronken, geen enkel probleem z1jn. In het café gedronken kan het de oorzaak z1 in van een ongeval op weg naar huls. Wat deze studie betreft wil ik het erbij laten, waar relevant, te vermelden dat niet alleen aspekten van het drinkpatroon, maar ook met het drinkpatroon samenhangende leefwl jzen kunnen bijdragen aan een verhoogde kans op nadelige gevolgen.

IX.2.1.1. Verschillen tussen mannen en vrouwen

Bif vrouwen in Limburg en Rotterdam is in veel sterkere mate incidenteel matig drankgebrulk het gangbare drinkpatroon dan b1f mannen. Aangezien bif incldenteel matig drankgebruik per definitle noolt meer dan acht keer per maand wordt gedronken, betekent dit dat, bif overeenkomstig konsumptlenivo, bif vrouwen meer nadelige gevolgen zifn te verwachten dan bif mannen. Immers, dezelfde hoeveelheld drank wordt in een kleiner aantal drinksessies opgedronken waardoor de hoeveelheld per keer hoger moet $z 1 \mathrm{Jn}$.

Een ander faktor thet gemiddeld lagere 11chaamsgewicht bif vrouwen- zou er cok toe kunnen bijdragen dat, b1f overeenkomstige hoeveelheid drank, vrouwen meer nadelige gevolgen van drankgebrulk ondervinden dan mannen. Aangetoond is name11jk dat b1f geringer lichaamsgewicht een zelfde dosis alkohol tot een hoger bloed-alkoholgehal te leldt.

Er is echter éên andere omstandigheld die me ervan weerhoudt voorstaande in een hypothese vast te leggen: bif mannen is drankgebrulk in sterkere mate een vanzelfsprekende gewoonte dan bif vrouwen. In het verlengde hlervan is het mogellfk dat b1f mannen vaker dan bif vrouwen incidenteel onmatig drankgebrulk voorkont, hetgeen wél tot melding van bv. dronkenschap en kater leldt, echter nlet tot uftdrukking komt in opgaven van de respondent over wat h1j 'gemiddeld' drinkt dan wel de afgelopen week heeft gedronken.

Derhalve geef ik er de voorkeur aan on aan de hand van de resultaten tot interpretatle over te gaan.

De varlabele geslacht is volgens de variantieanalyse, signiflkant van invloed op de skore op de Index, ook als gekon- 
troleerd wordt op konsumptienlvo (zle bifl. tabel 6 voor variantieanal yse)

In tabel $13 \mathrm{zifn}$ de geschatte skores voor mannen en vrouwen gepresenteerd. Bif mannen is, bif overeenkomstig konsumptienivo, de kans op melding van nadelige gevolgen hoger dan bij vrouwen. In Limburg is het verschil in geschatte skore op de Index (.68) groter dan in Rotterdam (.35). Op verschilien tussen Rotterdam en Limburg zal in de slotparagraaf worden ingegaan.

Tabej. 13: Geschatte skore op de index voor nadelizge gewolgen bij mannen en vwouwern

\section{LIMUURA}

Skore op de index yoor naide inge gevolgen
Oneargepaste
skore op index

Oneargepaste
shore op index
Gesuhatite slore op irndex met lontir. op cons antwo man
nouw

750

648

706
726

man

vrould
2.36

0.98

$\mathrm{eta}=0.29$

$r=0.269$

ROMTERDAM
1.73
0.86

tan $=0.20$

$x^{2}=0.230$ beta $=0.08$

Waarschifnlifk komt bif mannen vaker dan blj vrouwen incldenteel onmatig drankgebruik voor, hetgeen zou betekenen dat nlet het drinkpatroon op zich, maar een met drinkpatroon samenhangende leefwilze, leldt tot verschillen tussen mannen en vrouwen in de mate waarin deze bif overeenkomstig konsumptienivo nadelige gevolgen van drankgebrulk ondervinden. Analyse waarbij in plaats van de index de vier onderschelden soorten nadelige gevolgen als afhankelijke varlabelen worden gebrulkt, geeft als belangrijkste ultkomst dat in Rotterdam 
en Limburg bly mannen de skore op symptomen en problemen met de gezondheld en ongelukken hoger is.

IX.2.1.2. De invloed van leeftijd en soclale klasse b1J mannen en vrouwen

Leeft1jd

In hoofdstuk VI bleek dat er in LImburg forse verschl11en waren in drinkpatroon tussen mannen jonger en ouder dan 30 jaar. BIJ Jongere mannen was het drinkpatroon perlodiek veel drinken veel sterker dominant dan bij oudere mannen; bif oudere mannen daarentegen komt bifna dagel1jks thuls drinken vaker voor.

Bif perlodiek veel drinken is de frekwentie van drankgebruik per def'lnitle beperkt tot maximaal 20 keer per maand (zle ook schema II), terwIJl bif dagellfks thuls drinken eenzelfde hoeveelheid drank in principe over een groter aantal drinkgelegenheden gekonsumeerd kan worden. Derhalve kan verwacht worden dat, bij overeenkomstig konsumptlenivo, de hoeveelheld die per keer wordt gedronken bif jongere mannen gemiddeld hoger is en dat in het verlengde daarvan de kans op schadelijke gevolgen groter is.

Fenzelfde verwachting geldt voor Rotterdam. Wellswaar zijn de verschillen in drinkpatroon tussen jongere en oudere mannen minder geprononceerd. Fen overeenkomst $1 \mathrm{~s}$ echter dat in Rotterdam blf Jongeren twee drinkpatronen, die per definltie beperkt zifn in de frekwentle van drankgebrulk-incidenteel matig drankgebruik en de mengvom- vaker voorkomen, terw1jI bif oudere mannen bifna dagel1jks thuis drinken vaker voorkont.

Voor vrouwen kumnen dezelfde verschtllen in kans op nadelige gevolgen naar gelang leeftijd worden verwacht als bif mannen. Voorzover er verschllien in drinkpatroon naar leeft1jd zI jn bij vrouwen, komen bif vrouwen Jonger dan 30 jaar vaker drinkpatronen met een beperkte frekwentle van drankgebrulk (1.c. periodiek veel drinken in Llmburg en de mengvorm in Rotterdam) voor; b1 oudere vrouwen komt b1Jna dagelljks thuis drinken vaker voor dan bif Jongere vrouwen. 
Soclale klasse

In Rotterdam zljin er bij mannen geen opvallende verschilien in drinkpatroon naar sociale klasse. Derhalve $z 1$ in er geen verschillen te verwachten tussen de onderschelden soclale klassen, in de mate waarin b1j overeenkomstig konsumptientvo nadelige gevolgen optreden.

In Limburg zijn er wel verschillen. Perlodiek veel drinken komt vaker voor bij jongere mannen uit lagere en middenklasse dan b1j jongere mannen ult de hogere klasse. Bijna dage$11 \mathrm{jks}$ thuls drinken komt bij mannnen ouder dan 30 jaar vaker voor in de hogere klasse dan in midden- en lagere klasse. Wordt een analoge redenerling gevolgd als hiervoor, dan is te verwachten dat, bij overeenkomstig konsumptlenivo, in de lagere soclale klasse meer nadelige gevolgen optreden.

Bif vrouwen is er zowel in Rotterdam als in Limburg één opmerkelijk verschil tussen de soclale klassen in gangbaar drinkpatroon: in de hogere soclale klasse komt vaker b1jna dagelijks thuis drinken voor, in de lagere sociale klasse vaker incidenteel matig drankgebrulk.

op grond hiervan is te verwachten dat bij overeenkomstig konsumptientvo in de lagere soclale klassen de kans op melding van nadelige gevolgen hoger is.

Analyse

In de analyse kon de invloed van leeftijd en sociale klasse tegelifkertijd worden nagegaan omdat de F-waarden berekend worden na kontrole op de andere variabelen die in de analyse z1Jn opgenamen.

U1t tabel 7 in de biflage blijkt dat zowel bij mannen als bij vrouwen leeftijd slgnifikant van invloed is op de skore op de Index, ook als gekontroleerd wordt op konsumptientvo en soclale klasse. Soclale klasse is nlet van invloed. De invloed van leeftijd is in de verwachte rlchting: jongeren hebben een hogere skore op de Index dan ouderen. In onderstaande tabel zijn de geschatte skores op de index naar gelang leeftijd weergegeven.

Vermeldenswaard is dat bif mannen de verschillen naar leeftijd groter zijn dan bif vrouwen. Naar $1 \mathrm{k}$ vermoed omdat b1j mannen de verschillen in drinkpatroon tussen leeftijdsgroepen groter zijn dan bij vrouwen. Dezelfde oorzaak kan aangevoerd worden voor de in Limburg, vergeleken met Rotterdam, grotere verschilien tussen jongere en oudere mannen. 
Trabt 14: Geschatse akores op index voor radelige

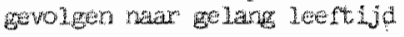

\section{LMEUAR}

mainger

Mrowiten

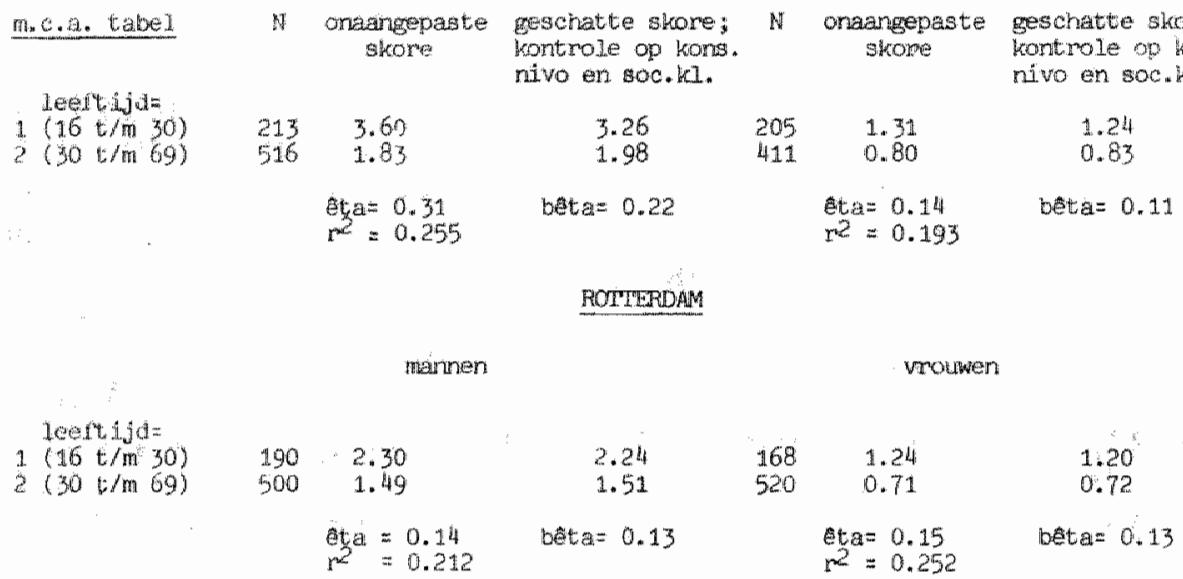

Irmers, in Limburg $\mathrm{z} i \mathrm{fn}$ de verschillen in drinkpatroon tussen jongere en oudere mannen groter dan in Rotterdam.

Blifkens tabel 7 in de biflage zifn er noch bif mannen noch bif vrouwen verschillen in skore op de index naar gelang soclale klasse. Voor mannen in Limburg en vrouwen in Limburg en Rotterdam wijkt dat af van de eerder geformuleerde verwachting.

Uit de analyse warin de afzonderlijke soorten nadelige gevolgen als afhankellfke varlabelen worden ingevoerd blifkt dat er wel verschil is naar gelang sociale klasse. In Rotterdam is, na kontrole op konsumptienivo en leeftifd, b1j mannen en vrouwen uit de lagere soclale klasse de frekwentle van dronkenschap/kater hoger. In Limburg is bif mannen en vrouwen ult de lagere soclale klasse de skore op de varlabele symptomen hoger. (zle schema II in biflage). Voor mannen in Rotterdam werd dit verschil overigens niet verwacht. Aan soclale klasse kan derhalve Invloed worden toegeschreven wat betreft dronkenschap/kater (Rotterdam) of symptomen (Limburg), zif het dat deze Invloed nlet zo groot is dat de- 
Tabel 15: Geschat te inwloed tan gewenning op skore op index voor nadelige gevolgen

\section{ITMURG}

Manner

Durur huidig drankgebruik

minder dan 2 jaar

$2 \mathrm{t} / \mathrm{m} 4$ jaar

$5 \mathrm{t} / \mathrm{m} 9 \mathrm{jaar}$

10 jaar bf langer

minder dan 2 jaar

$2 \operatorname{tim} 4$ jaar

$5 \mathrm{t} / \mathrm{m} 9 \mathrm{jar}$

10 jaar of langer
N

onaangepaste skore

105

151

185

322

\section{Wrouwen}

$\begin{array}{ccc}89 & 1.39 & 1.37 \\ 122 & 1.38 & 1.21 \\ 147 & 1.07 & 1.02 \\ 254 & 0.69 & 0.81 \\ & \text { eta= }=0.18 & \text { beta }=0.12 \\ & & r^{2}=0.15\end{array}$

ROTTEPDAM

Mariner

Yuinder dan 2 jatar

110

2.73

2.51

$2 \mathrm{t} / \mathrm{m} 4 \mathrm{jaar}$

124

166

322
2.29

1.67

1.41

$0 t a=0.19$
$5 \mathrm{t} / \mathrm{m} 9 \mathrm{jtar}$

10 jaar of langer

(1)

niet signifikant geschatte store bij

kontr. op kons mivo en leeftija 
ze cok in de skore op de Index voor nadelige gevolgen te herkennen 1s. Verwerpen van de hypothese 11jkt me voorbarig. Wel moet gesteld worden dat soclale klasse een beschelden invloed heeft.

\section{IX.2.2. Gewenning}

De ultkomsten van de variantleanalyse waarin de invloed van gewenning, geindlceerd door de duur waarmee huldig aantal glazen wordt gedronken, wordt nagegaan, staan in tabel 8 van de biflage. Behalve konsumptienivo, is ook leeftijd als kovarlant in de analyse opgenomen. In nevenstaand tabel $\mathrm{z}$ fn, voorzover gewennlng slgniflkant van Invloed 1s, de geschatte skores weergegeven.

Het blijkt dat bif mannen in Rotterdam en bij vrouwen in Limburg het verwachte verband met de skore op de Index voor nadelige gevolgen wordt gevonden. B1f mannen in Limburg en bil vrouwen in Rotterdam niet. Een nogal ongemakkelf jke ut komst als het erom gaat de hypothese te verwerpen of te bevest1gen! Worden in plaats van de index voor nadelige gevolgen, de afzonderlijke kategorleën nadelige gevolgen als afhankelijke varlabele ingevoerd, dan blijkt er voor vrouwen in Rotterdam nog steeds geen enkele invloed van gewenning op nadellge gevolgen van drankgebrulk. (zle schema II in bljlage) Voor mannen in Limburg wordt nu echter wel een verband gevonden met psychologiese afhankelljkheld, evenals voor mannen in Rotterdam en vrouwen in LImburg (b1jl., schema II).

Samenvattend kan gesteld worden dat in drie van de vier populatles de skore op psychologlese afhankelifkheld lager is b1j grotere gewenning; in één populatıe zlın tevens de skores op symptomen en problemen met gezondheid/ongelukken lager bif grotere gewennting.

De twee voornaamste vragen die deze uitkomsten oproepen ziljn:

- Gewenning of verworven tolerantle wordt in de 11teratuur vooral van invloed geacht op fysiologles bepaalde gevolgen van drankgebruik als dronkenschap, black-outs. In slechts 1 populatie (mannen in Rotterdam) wordt deze samenhang gevonden. 
- Meestal wordt niet verondersteld dat gewenning de afhankelifkheid doet afnemen. Integendeel, veelal gaat men ervan uit dat bif langere duur van overmatig drankgebruik ook de psychologlese afhankelijkheld groelt (van Epen, 1974, van Difk 1976).

Het antwoord op de eerste vraag ligt, naar ik aanneem, in het felt dat duur van huidig drankgebrutk een ongeldige indikator is voor gewenning. Gewenning of verworven tolerantle moet, naar ik nu genelgd ben aan te nemen, als een meer dynamies proces worden opgevat: men moet steeds meer gaan drinken on dezelfde effekten te bereiken. Bif de meer statlese Indicering van gewenning die ik heb aangehouden is klaarblijkelijk slechts sporadies sprake van een verminderde kans op fysiologies bepaalde nadelige gevolgen.

Het antwoord op de tweede vraag, ben $1 \mathrm{k}$ eveneens genelgd te zoeken in foutleve indicering, nu echter van psychologiese afhankelijkheld.

Naar ik vermoed is het te nalef om te veronderstellen dat 'doorgewinterde' drinkers (1.c. bif langere duur van overmatig drankgebruik) niet zouden beseffen dat drankgebruik slechts een t1jdelljke en ontoereikende oplossing is. Dat men b1f langere duur van drankgebruik afleert drankgebrulk te waarderen als oplossing voor problemen, sluit overigens bepaald nlet uit dat de afhankelijkheld van drank am met onopgeloste problemen verder te leven toeneemt.

Bij kortere duur van overmatig drankgebruik, is het naar ik aameem nog mogelijk om onbevangen de spanningsreducerende werking van alkohol als 'oplossing' van problemen te ervaren. In drie van de vier populatles is voor deze redenering bevestiging te vinden.

Duldelijk zal $\mathrm{zl}$.jn dat de oorspronkel1jke hypothese verworpen dient te worden. Wel is er aanleiding voor een nteuwe hypothese, die in de diskussle geformuleerd zal worden.

IX.2.3. De invloed van strukturering van het dagelijks leven

B1, de analyse van de invloed van strukturering op het dagelijks leven is, vanwege de hlervoor gebleken samenhang met de skore op de index, behalve op konsumptientvo ook op leeftijd gekontroleerd.

Blijkens de tabel van de variantleanalyse (tabel 9 in bijla- 
van dronkenschap/kater. Het verschil is zelfs vrly groot genoemd worden: b1f een skore van 0 op de varlabele strukturering van het dagel1jks bestaan is de frekwentle van dronkenschap/kater rulm 7 punten hoger dan b1j vrouwen met een skore van twee of hoger. In Rotterdam is het overeenkomstige verschil niet groter dan 2.41. Anders gezegd: vrouwen ult Limburg zonder werk, partner of zorg voor thulswonende kinderen zifn, bif overeenkomstig konsumptienivo en kontrole op leeftijd, rutm 1 keer per maand vaker dronken dan andere vrouwen. Dit mag naar mijn mening gewaardeerd worden als relevante invloed. Derhalve is er ook voor vrouwen in Limburg steun voor de hypothese, dat strukturering van het dagell.jks leven van invloed is op de mate waarin nadelige gevolgen van drankgebruik worden ondervonden.

B1f de mannen valt op dat in Rotterdam de verschillen in skore op de index naar gelang strukturering (2.44) beduldend groter zifn dan in Limburg (0.77) In de hiernavolgende paragraaf zal 0.a. gepoogd worden de achtergronden van dit verschil tussen Limburg en Rotterdam toe te lichten.

Tot slot van deze paragraaf $w 11$ ik er nog op wljzen dat het met name dronkenschap/kater en symptomen zijn die worden beinvloed door statusfaktoren en strukturering van het dagel1.jks leven. (schena II in de biflage).

Voor gezondheld/ongelukken en psychologlese afhankel1,jkhe1d worden minder vaak de verwachte samenhangen gevonden.

IX. 3. Strukturer1ng van dagel1jks bestaan en nadelige gevolgen: een nadere analyse

Is het nu vooral werk of vooral het samenleven met een partner of vooral de zorg voor thulswonende klnderen dan wel een komblnatle van twee of drle van deze indikatoren voor strukturering van het dagelijks bestaan die van invloed $\mathrm{zl}$ fn op de mate warin drankgebrulk gepaard gaat met nadelige gevolgen? Dit is de eerste vraag waarmee $1 \mathrm{k}$ me in deze paragraaf w11 bezighouden.

Daartoe zijn in plaats van de varlabele strukturerlng van het dagel1jks leven, de afzonderl1jke 1ndikatoren voor deze varlabele als faktoren in een Anova-analyse opgenomen. Er is gekontroleend op konsumptienivo en leeft1jd. 
In schema $\mathrm{V}$ z1.jn de voomaamste ultkonsten weergegeven. In de blflage (tabel 10) staat de tabel met de varlantleanalyse. De geschatte skores op de index worden niet weergegeven, aangezlen er sprake 18 van interaktie tussen al dan nlet werkend, met/zonder partner en al dan geen zorg voor thuiswonende kinderen. Deze interaktle maakt de ultkomsten van de "multiple classiflcation analysis" onbetrouwbaar.

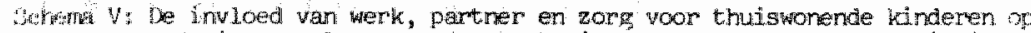
nadelige gevoll wen van drankgebuik na kontrole op konsumptientiso eriegtija
}

MANDEN

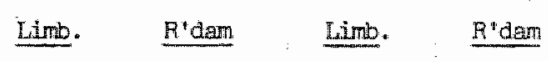

Direkte invloed

werts

partiner

zorg voor thuiswonende kinderen

Tweeweg interakties

werk net partriar

werk mpt zorg voor thuiswonerde

kinceren

partiner met zorg voor thuls-

wonerde kinderen

Driewes interalties

werk ery partiner on uorg woom

truiswonende kinderen

\begin{tabular}{|c|c|c|c|}
\hline \multicolumn{2}{|c|}{ MANREN } & \multicolumn{2}{|c|}{ VROTWEN } \\
\hline Limb. & $R^{\prime}$ dam & Eunb. & R'dem \\
\hline $\begin{array}{l}p<0.05 \\
p<0.05\end{array}$ & $\begin{array}{l}p<0.05 \\
p<0.05\end{array}$ & $\begin{array}{l}\text { n.s. } \\
\text { p.p.05 }\end{array}$ & $\begin{array}{l}\text { n. } \$ . " \\
p<0.05\end{array}$ \\
\hline n.s. & n.s. & ris. & n. 3. \\
\hline $\mathrm{n} . \mathrm{s}$. & $p<0.05$ & n..s. & n.s. \\
\hline n.s. & n.s. & M.s. & n.s. \\
\hline$n \cdot s$. & $p<0.05$ & $n \cdot s$. & n. $s$. \\
\hline & & & \\
\hline 000.05 & n.s. & ก.s. & nis.s. \\
\hline
\end{tabular}

De voornaamste konklusles die uit het schema getrokken kunnen worden $\mathrm{z} \perp \mathrm{Jn}$ :

- zorg voor thulswonende kinderen is blj geen van de vier populaties direkt van invloed op de kwetsbaarheld voor nadellge gevolgen. BIJ mannen is er in kombinatie met het ontbreken van een partner (Rotterdam) of partner en werk (IImburg) nog enige Invloed van zorg thulswonende kinderen

- b1j vrouwen heeft ook het ontbreken van werk geen signifikante invloed op de kwetsbaarheld voor nadelige gevolgen.

Uit tabel 10 in de b1jlage kan aan de hand van de F-waarden nog de konklusle getrokken worden dat blj mannen in Rotterdam het ontbreken van werk of partner sterk bijdragen aan een verhoogde kwetsbaarheld dan bij mannen in Limburg. Dit 
is ongetwijfeld de achtergrond van de in de vorige paragraaf gesignaleerde grotere Invloed van strukturering van het dagelljks bestaan in Rotterdam. In de diskussie zal op het verschil tussen Limburg en Rotterdam worden teruggekomen.

De tweede vraag die $1 \mathrm{k}$ in deze paragraaf wil behandelen gaat nog een stapje verder: Is er bij het ontbreken van werk nog verschil in de mate waarin werkzoekenden, arbeldsongeschikten en gepensioneerden kwetsbaar zifn voor nadelige gevolgen van drankgebruik? En, is er bif het ontbreken van een partner nog verschil in de mate waarln gescheidenen, noolt gehuwden en verweduwden kwetsbaar zijn voor nadelige gevolgen van drankgebrulk?

om op deze vraag een antwoord te geven, is Anova-analyse uitgevoerd met achtereenvolgens werk- en gezinssituatie als onafhankelijke variabelen en de vier onderschelden kategorleën nadelige gevolgen als afhankelijke varlabelen. Door in plaats van met één, met vier afhankelijke varlabelen te werken, wordt de kans op signifikante samenhangen vergroot. Mijns inziens een bruikbare werkwijze als het, zoals hier, gaat on het exploreren van relevante verschillen.

De analyse naar werksituatie is niet voor vrouwen uitgevoerd, aangezien in het voorgaande bleek dat al dan niet bultenshuis werken bij vrouwen niet van invloed is.

In alle analyses zijn konsumptienivo en leeftijd als onaf"hankel1jke varlabelen opgenomen, bif de analyse naar werksituatie is daarenboven soclale klasse als kontrolevartabele ingevoerd.

In schema VI is de rangordening naar kwetsbaarheld voor nadelige gevolgen van de onderscheiden groeperingen weergegeven. Het schema is gebaseerd op de uitkomsten van de 'mult1ple classiflcation analysis" die in tabel II van de biflage Is opgenomen.

De twee voomaamste uitkonsten zifn:

- B1y werkzoekende mannen wordt het vaakst de hoogste kwetsbaarheld voor nadelige gevolgen gevonden. Arbeldsongeschikten $\mathrm{zIjn}$ vaker $(3 \mathrm{x})$ dan gepensioneerden $(1 \mathrm{x})$ de op één na meest kwetsbare groep. B1j het ontbreken van een maatschappel1jk normaal geachte arbeldsrol

(werkzoekende, arbeldsongeschikt) is de kwetsbaarheld voor nadellge gevolgen van drankgebruik derhalve groter dan in het geval de arbeldsrol on een maatschappelljk meer aanvaardbare reden is weggevallen (gepensioneerden). 


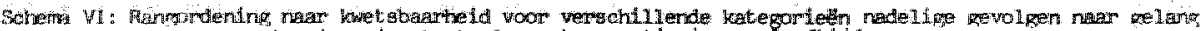

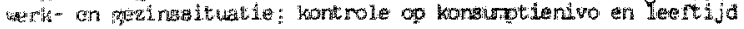

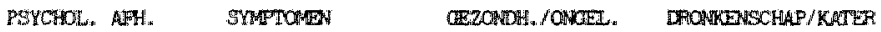

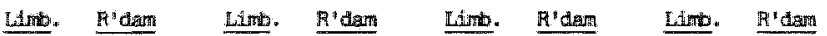

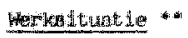

mulgyers

werekend.

werthecekend

n. 3. ni.

$\begin{array}{ll}3 & 4 \\ 2 & 1 \\ 1 & 3 \\ 3 & 2\end{array}$

$\begin{array}{ll}4 & 4 \\ 1 & 2 / 3 \\ 2 & 1\end{array}$

ก. $\begin{aligned} & 4 \\ & \frac{1}{1} \\ & 2 \\ & 3\end{aligned}$

gopensiones

Dezunge ituat le

rearyen:

nots partener

noolt prowis

geacheider

tumatrar

vagupen

met piartner

noolit ggebust

geache 1dem

nedure

3
2
1

3
2
1
.

3
2
1

n.s.

$\begin{array}{lll}3 & 3 & 3 \\ 2 & 2 & 2 \\ 1 & 1 & 1 \\ 1 & & 1\end{array}$

- n te kliein on "konklusies hleraan te verbinden

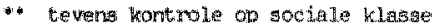

1 het meent lowetribarar

it het mintst thetrobar.

B1. mannen en vrouwen in Limburg en in Rotterdam kan aan de gescheldenen een grotere kwetsbaarheld voor nadelige gevolgen van drankgebrulk worden toegeschreven dan aan noolt gehuwden.

B1J het ontbreken van een maatschappel1jk normaal geachte gezlnsrol 1.c. gescheldenen- is er derhalve sprake van een in sterkere mate verhoogde kwetsbaarhe1d voor nadelige gevolgen dan wanneer een partner om maatschappel1 Jk aanvaardbaarder redenen ontbreekt (1.c. noolt gehuwden en verweduwden). 
Samenvatting/diskusste

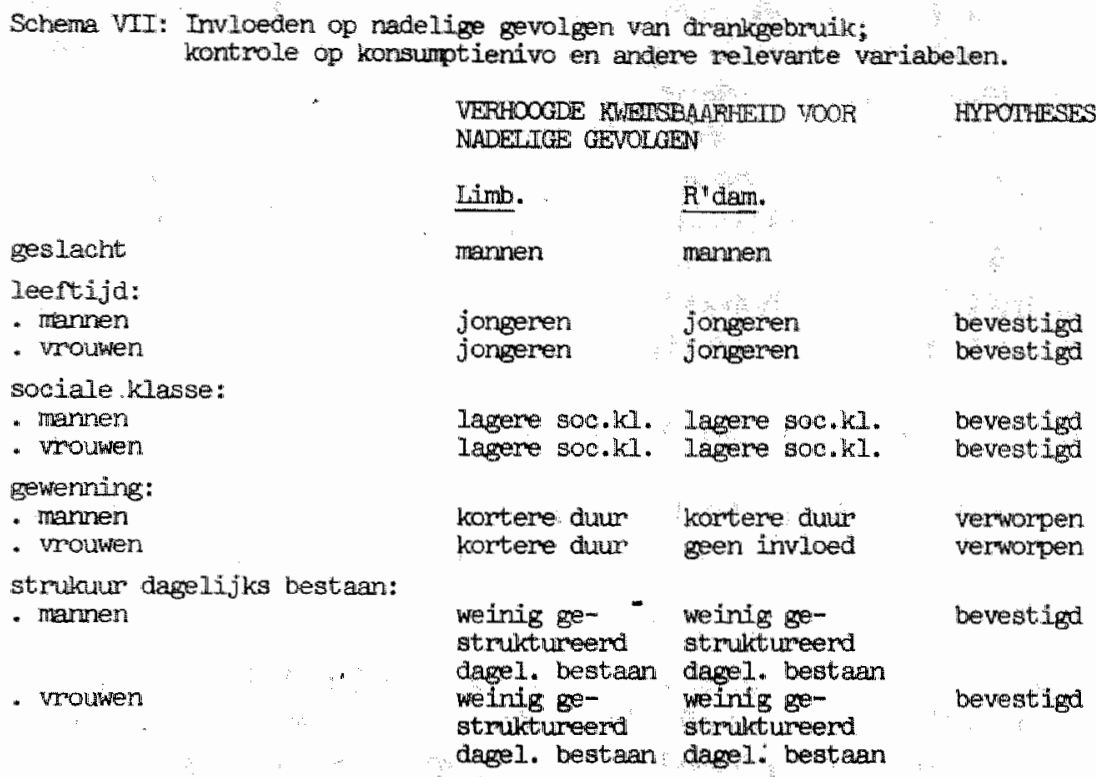

In bovenstaand schema $z 1 \mathrm{jn}$, vereenvoudigd, de uttkomsten van de analyse wat betreft de hypothesen samengevat.

Alleen de hypothese betreffende gewenning moet worden verworpen. Voor de andere hypothesen $1 \mathrm{~s}, \mathrm{z} 1 \mathrm{f}$ het in wisselende mate, steun te vinden.

De eenvoud van het schema kan misleldiend zijn als er niet de nodige kanttekeningen bij gemaakt worden. Die will ik dan ook allereerst maken on vervolgens gedetallleerder de ultkonsten te bespreken.

Waar de resultaten daartoe aanlelding geven, zullen nleuwe hypothesen geformuleerd worden.

B1f de invloed van geslacht op nadelige gevolgen, moet de kanttekening gemaakt worden dat de rlchting van de invloed niet afgeleld kan worden uit het verschil in drinkpatroon tussen mannen en vrouwen. Op grond van het verschtl in drinkpatroon is namelijk te verwachten dat vrouwen vaker nadelige gevolgen van drankgebrulk ondervinden dan mannen. 
De resultaten laten zien dat b1j mannen vaker nadelige gevolgen van drankgebrulk voorkomen. Ter verklaring is aangevoerd dat drankgebrulk bij mannen in sterkere mate tot de vanzelfsprekende gewoonten behoort. In het licht daarvan wordt het waarschijniljk geacht dat mannen vaker op onregelmatige tijdstippen dusdanig veel drinken dat zich bv. dronkenschap of symptomen van drankgebrulk voordoen. Dit incldenteel ormatlg drankgebrulk komt dan niet tot ultdmuking in opgaven van de respondent over het gemiddeld aantal glazen per das of per week. De gevolgen ervan echter worden waarschljnlljk wel gemeld, cok andat er gerlcht naar gevraagd wordt tijdens het interview.

Wat betreft leeft1jd waren de resultaten geheel konform de verwachting.

Jongeren ondervinden, bif overeenkonstig konsumptienivo, in sterkere mate nadelige gevolgen van drankgebrulk dan ouderen.

De invloed van soclale klasse is beschelden te noemen. Voor mannen in Rotterdam werd deze invloed overigens niet verwacht, ondat er in Rotterdam b1 I mannen geen noemenswaardige verschillen in drinkpatroon naar gelang sociale klasse zijn. Wellicht dat, ook bij het ontbreken van verschilien in drirkpatroon, er in de lagere soclale klasse een sterkere tendens tot incidenteel ommatig drankgebruik is. Cartwrlght e. a. (1978b) vonden eveneens dat in de lagere soclale klasse, na kontrole op konsumptienivo en de hoeveelheld per keer, vaker nadelige gevolgen worden ondervonden.

De hypothese betreffende gewenning moet worden verworpen. Er worden wel signiflkante samenhangen gevonden tussen de indikator voor gewenning-duur waarmee men het huldige aantal. glazen per dag drinkt- en nadelige gevolgen. Echter de vaakst voorkomende samenhang betreft die tussen gewenning en psychologlese afhankel1jkheid. Ten aanzlen van meer fysiologles bepaalde gevolgen van drankgebrulk, wordt alleen blj mannen in Rotterdam een samenhang gevonden tussen gewenning en symptomen en problemen met de gezondheld/ongelukken. Dit wordt onvoldoende steun geacht on de hypothese bevestigd te achten. 
Wel is er, gezien de samenhang met psychologlese afthankelifkheld aanlelding voor een nieuwe hypothese:

har gelang men korter het huidige aantal glazen per dag drinkt zal, bij overeenkomstig konsumptienivo, de mate van psychologiese afhankelijkheid hoger zijn.

Deze hypothese staat op gespannen voet met de opvating dat "alkoholisme" een proces 1s dat zich kermerkt door toenemende afhankel1jkhe1d (van Epen, 1974, van D1Jk, 1976). Zeer waarschijnlijk echter is de hier en in andere studies gebruikte indicerling van psychologlese afhankelijkheld (Cahalan, 1976; Mulford, 1977; Celentano, Mc Queen 1978b) nlet geschikt on een groelende psychologiese afhankel1jkheld van alkohol vast te stellen.

Met ultzondering van de vrouwen in Limburg, kon de Invloed van de strukturering van het dagel1jks bestaan op de skore op de Index voor nadelige gevolgen worden aangetoond.

Bij vrouwen in Limburg is de samenhang net nlet signifikant $(p=0.067)$. Wel bleek bif vrouwen in Limburg de strukturering van het dagelljks leven sterk van invloed te zijn op één van de afzonderlljke soorten nadelige gevolgen: de frekwentie van dronkenschap/kater. Deze laatste ultkomst, en het felt dat de samenhang met de index voor nadelige gevolgen net niet slgniflkant was, werd reden genoeg geacht om ook wat betreft vrouwen in Limburg de hypothese bevestigd te achten.

Hiemee zifn de kanttekeningen bif het eerder gegeven schema gemaakt. Blifft over een nadere beschouwing van de resultaten vanuit meer specifleke invalshoeken.

Gezien de resultaten is er aanlelding om de verschilien tussen mannen en vrouwen en tussen IImburg en Rotterdam nader te bespreken. Daarmee zal begonnen worden. Aan het slot van de paragraaf zal nog ingegaan worden op de vraag of er relevante versch11len $z 1 . j n$ in kwetsbaarheld voor nadelige gevolgen naar gelang een maatschappel1jk nomaal geachte positierol ontbreekt dan wel het ontbreken van een positierol als meer vanzelfsprekend wordt ondervonden. Tevens of gekomb1neerd gebrulk van slaap- of kalmerende middelen en alkohol mede de verhoogde kwetsbaarheld voor nadelige gevolgen in bepaalde groeperingen veroorzaakt. 
Verschllien tussen mannen en vrouwen

De resultaten laten duldelljke verschillen tussen mannen en vrouwen zien. Deze betreffen niet of de in de hypothesen genoemde faktoren van invloed zijn. Wel de màte waarln deze faktoren bif mannen en vrouwen van invloed $\mathrm{z} 1 \mathrm{Jn}$. Er wordt namelijk gevonden dat

- b1j mannen de 1nvloed van leeftijd groter 1s,

- b1j mannen de Invloed van strukturering van het dage11jks bestaan op nadelige gevolgen van drankgebrulk groter is dan bif vrouwen,

- b1j mannen heeft de faktor wel/geen partner op een groter aantal soorten nadelige gevolgen invloed dan bij vrouwen.

De corzaak voor het verschil in de mate warin leeftijd bij mannen en vrouwen van invloed is, moet deels gezocht worden In het felt dat de verschillen in drinkpatroon tussen jongere en oudere vrouwen, kleiner zifn dan de verschilien in drinkpatroon tussen jongere en oudere mannen.

Dat b1j vrouwen de strukturering van het dagelijks bestaan minder sterk van invloed is dan bij mannen, wordt mogelijk deels veroorzaakt doordat vrouwen het ontbreken van werk buitenshuis in mindere mate als een aanslag op een betekenisvol dagelifks leven ervaren. Mogelijk dat mannen zonder werk hierdoor meer spaniningen ondervinden en, daarmee samenhangend, in hogere mate kwetsbaar zijn voor nadelige gevolgen van drankgebrulk.

Onverklaard blifft in deze redenering waarom er, in tegenstelling tot de mannen, b1f vrouwen geen enkele Invloed van de zorg voor thuiswonende kinderen is aan te wl Jzen. Tevens blifft onverklaard waarom b1f vrouwen de invloed van het ontbreken van een partner geringer is dan big mannen. Men zou eerder verwachten dat de zorg voor kinderen en het ontbreken van een partner b1 f vrouwen sterker van Invloed zijn, ondat blf vrouwen de orlëntatle op het gezin, zeker wat betreft alledaagse aktiviteiten, sterker geacht kan worden dan bif mannen.

Naar ik vermoed is hier het relatief lage konsumptient vo van vrouwen van belang. In Limburg drinkt 1.1.\% van de vrouwen 6 of meer glazen op doordeweekse dagen en $5.3 \%$ van de vrouwen 
6 of meer glazen op weekenddagen. Voor mannen in Limburg zijn de overeenkomstige percentages mimschoots hoger: $7.1 \%$ op doordeweekse dagen en $21.5 \%$ op weekenddagen.

In Rotterdam zijn alle overeenkomstige percentages wat lager, het verschil tussen mannen en vrouwen is ook daar echter duidelijk.

Deze verschillen in konsumptie tussen mannen en vrouwen zijn naar ik aanneem het gevolg van sociale dmuk op vrouwen om hun konsumptie beperkt te houden (Knibbe, 1982). Gegeven deze sociale druk, speelt waarschijnl1jk het ontwljken van nadellge gevolgen van drankgebruik zo'n dominante rol, dat er geen grote verschillen in kwetsbaarheid van nadelige gevolgen kunnen ontstaan naar gelang leeftijd en strukturering van het dagelifks bestaan. De nieuwe hypothese luidt als volgt:

Gegeven de bij vrouwen grotere sociale druk tot matig

drankgebruik, zijn bij vrouwen de faktoren leeftijd

en strukturering van het dagelijks bestaan in mindere

mate van invioed op de kwetsbaarineid voor nadetige

gevolgen dan bij mannen.

Verschilien tussen Limburg en Rotterdam

In Limburg zijn geslacht en, b1j mannen, leeft1jd sterker van invloed dan in Rotterdam. In Rotterdam is strukturering van het dagelijks bestaan, zowel bij mannen als bij vrouwen, sterker van invloed dan in Limburg.

De achtergrond van de in Limburg sterkere invloed van geslacht en leeft 1 Jd is warschijnl1jk grotendeels te herle1den tot de in Limburg grotere verschillen in drinkpatroon naar gelang geslacht en -b1j mannen- leeftijd.

Als in plaats van stmukturering van het dagelijks leven, de onderschelden indikatoren voor deze varlabele genomen worden, zifn er nog steeds relevante verschililen tussen Rotterdam en Limburg te vinden. Naar $1 \mathrm{k}$ aanneem moet de achtergrond voor dit verschll gezocht worden in een in hoofdstuk VI en VII reeds ter sprake gekomen faktor: de in LImburg groter te achten integratle van drankgebruik in het leefpatroon. In Limburg bevat het drinkpatroon perlodiek veel drinken veel duldelijker aanwljzingen hoe te drinken dan de "mengvorm" in Rotterdam. Bovendien zijn de statusrol verwachtingen aangaande gewenst drinkpatroon in Limburg duldelijker (zie ook hoofdstuk VI en VII) De integratie van 
drankgebmuik in het leefpatroon bledt op zloh geen bescherming tegen nadelige gevolgen van drankgebrulk. Integendeel, in Limburg is het percentage probleemdrinkers signifikant hoger dan in Rotterdam (Knibbe, 1982; Garretsen, Knibbe, 1983). .

Het is echter goed voorstelbaar dat het bestaan van goed omschreven, met statusgenoten gedeelde drinkgewoonten ertoe b1 fdraagt dat, ook voor mensen met een weinlg gestmuktureerd dagelifks leven, drankgebruik in de eerste plaats een betekentsvolle soclale aktivitelt bllyft. Omgekeerd is het goed voorstelbaar dat, indien duldelljke soclale verwachtingen aangaande drankgebrulk ontbreken, julst voor die mensen, die in reaktie op een weinis gestruktureerd bestaan hun drankgebrulk intensiveren, nlet het soclale aspekt, maar het individuele 'effekt' van drankgebrulk sterker de nadruk krijgt. Verwaarlozing van het soclale aspekt tijdens het drinken kan lelden tot ofwel een sneller effekt van een zelfde hoeveelheld alkohol, dan wel tot een snellere registratie van het effekt van drank. Eveneens is mogel1jk dat indien drankgebrutk minder goed geintegreerd is in de statusrol, er vaker incldenteel ommatig drankgebrulk voorkomt. Aangenomen dat voorgaande redeneringen geldig zijn, wil ik nlet zozeer staande houden dat ultsluitend in Rotterdam drankgebmulk voor persoonl1.jk effekt en/of incldenteel onmatlig drankgebrulk voorkomt, doch wel dat dit in Rotterdam vaker voorkomt ondat in Rotterdam drankgebruik in mindere mate in het leefpatroon is geintegreerd dan in Limburg.

In de literatuur is veel te doen geweest over de invloed van integratile van drankgebrulk op de mate waarin drankgebrulk gepaard gaat met nadel Ige gevolgen (Bates, 1946, Straus, Bacon, 1953; Skolnick, 1958, Frankel, Whitehead, 1981). Inmiddels moet gesteld worden, dat als de onderzoeksresultaten worden gevolgd, er welntg aanlelding is on aan te nemen dat, naast het gemiddeld konsumptienlvo in een samenleving, ook de Intergratle van drankgebruik nog van invloed is op de mate waarln dranicgebrulik in de betreffende populatie gepaard gaat met nadelige gevolgen. (Frankel, Whitehead, 1981, Davies en Walsh, 1983). B1j mijn weten zijn er echter njet eerder systematies vergelijkingen gemaakt tussen kuIturen die verschillen in integratle van drankgebrulk. aangaande de Invloed van de strukturerling van het dagel1jks leven op de nadellge gevolgen van drankgebrulk. De hier gepresenteerde resultaten kunnen worden gezien als aanwljzingen dat deze 
Invloed er 1s. Voor de volgende nleuwe hypothese is dan ook aanleiding:

naar getang drankgebmik een minder sterk geintegreerd

gedragselement is, zal de kwetsbaarheid voor nadeizge

gevolgen van drankgebruik bij mensen met een weinig ge-

struktureerd dagelijks. zeven, groter zijn.

Ontbreken van maatschappel1jk normaal geachte rol

U1t de gedeta11leerde analyses kwam naar voren dat werkzoekenden en arbeldsongeschikten kwetsbaarder zi.fn voor nadelige gevolgen van drankgebruik dan gepensioneerden. Tevens dat gescheidenen, vergeleken met noolt gehuwden kwetsbaarder zifn. Derhalve kan gesteld worden dat het ontbreken van een door anderen en/of betrokkene zelf normaal geachte rol, kwetsbaarder maakt voor nadelige gevolgen van drankgebmulk dan wanneer het ontbreken van een positierol maatschappel1 jk gezlen minder opvalt.

Tot slot nog één opmerking over de konblnatle van slaapmiddelen en drankgebrulk. Aangezlen het gekombineerd gebruik van slaap- of kalmerende middelen en drankgebrulk zeker tot een verhoogde kwetsbaarheld voor nadelige gevolgen van drankgebrulk leldt (Hoogendoom, 1983), is nagegaan of er naar gelang strukturering van het dagelljks leven, verschil is in de mate waarin het gebruik van drank gekombineerd wordt met het dagelijks gebrulk van slaap- of kalmerende middelen.

Er is sprake van een tendens dat drinkers met een weinig gestruktureerd dagel1jks leven (skore 0 of 1 ) vaker dage$11 \mathrm{kks}$ slaap en kalmerende middelen gebrulken dan drinkers met een meer gestruktureerd dagel1jks leven (skore 2 of 3 ). BII mannen in Rotterdam is deze tendens nog het zwakst: $4.4 \%$ en $3.5 \%$ van de mamnen met respektlevel1 jk een welnig en goed gestruktureerd dagel1jks leven gebrulkt dagel1jks slaap- of kalmerende middelen. B1j mannen in Limburg $(5.1 \%$ en $2.3 \%$ ) en vrouwen in Lumburg $(7.5 \%$ en $3.3 \%$ ) en vrouwen in Rotterdam (9.4\% en $4.9 \%$ ) z1jn deze versch1lien in dagelljks gebruik van slaap- of kalmerende middelen naar gelang strukturering van het dagel1,jks bestaan groter. Bovenstaande doet derhalve vermoeden dat de kombinatie van alkoholhoudende drank en slaap- of kalmerende middelen bijdraagt aan de verhoogde kwetsbaarheld voor nadelige gevolgen van drankgebruik blj 
mensen met een weinig gestruktureerd dageli jks leven. Worden de uitkomsten van dit hoofdstuk in een flguur samengevat dan zlet deze er als volgt uit.

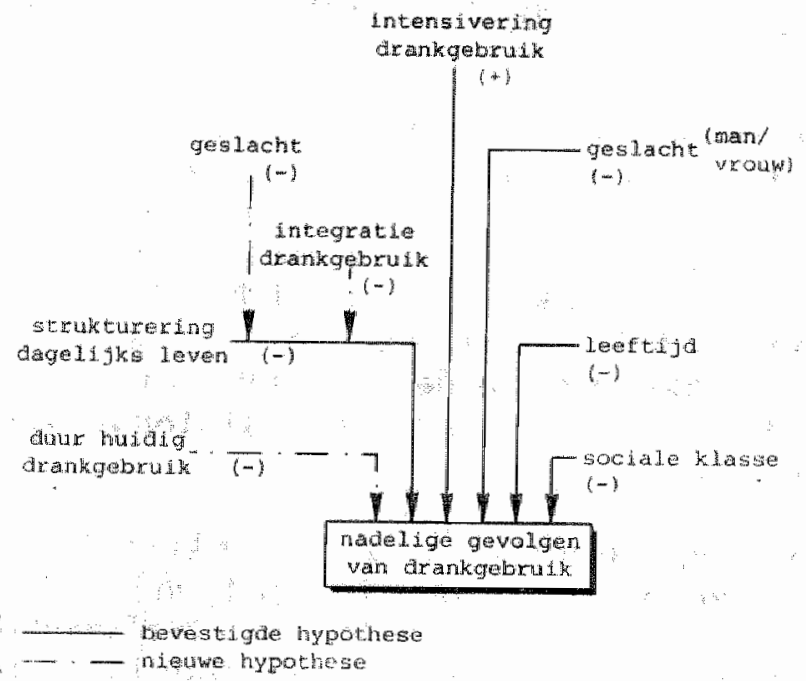

De hypothese betreffende gewenning is vervallen, wel is een verband gelegd tussen duur hutdig drankgebrulk en nadelige gevolgen, waarbij aangetekend dient te worden dat dit verband met name psychologlese afhankelijkheld treft. Vergeleken met de oorspronkellyke hypothesen, is in dit schema nleuw dat geslacht en Integratie van drankgebruik ingevoerd zifn als faktoren, die de mate waarin leeftijd en strukturering van het dagelljks leven van invloed is op nadelige gevolgen, konditioneren. 


\section{$X$ Faktoren van invloed op zorgen en afkeuring}

\section{I. Inlelding}

In hoofdstuk IV werden over de kans op afkeurlng van of zorgen over drankgebrulk een aantal hypothesen geformuleerd die in onderstaande flguur binnen het amlifnde gedeelte zi.jn weergegeven.

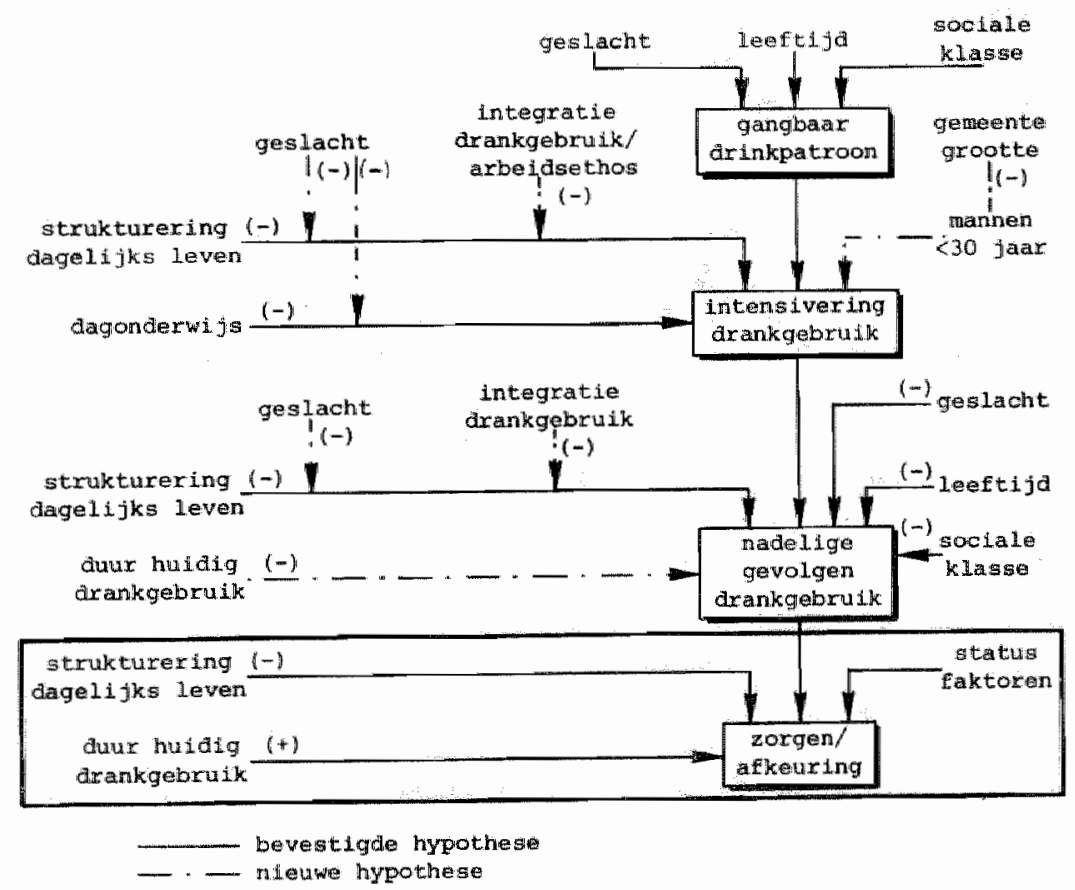

De hypothesen luiden als volgt:

In statusgroeperingen waar een drinkpatroon gangbaar is dat vergelijkenderwijs vaak gepaard gaat met nadelige gevolgen, is de kans op afkeuring van of zorgen over drankgebruik geringer dan in statusgroeperingen war het drankgebruik minder vaak gepaard gaat met nadelige gevolgen. 
Naamate men langer het huidige cantal glazen per dag drinkt aal, ook bij kontrole op de mate van nadelige gevolgen, de kans op zorgen over en ajkeuring van drankgebruik groter zijn.

Bij kontrole op de mate van nadelige gevolgen van drankgebruik, zal de kans op zorgen over en afkeuring van drankgebruik groter aijn bij drinkers met een weinig gestruktureerd dage lijks teven.

B1f de laatste hypothese zal nagegaan worden of meer spec1flek het ontbreken van een maatschappel1Jk nomaal geachte rol, dan wel in het algemeen het ontbreken van rollen die struktuur geven aan het dagel1jks leven, le1dt tot versch11len in kans op zorgen of afkeuring.

Verschillen tussen statusgroeperingen in kans op afkeuring of zorgen, worden alleen verwacht voorzover deze statusgroeperingen verschillen in de mate waar in nadelige gevolgen van drankgebrutk worden ondervonden. In b1jlage $\mathrm{I}$, tabel $12 \mathrm{z} 1 \mathrm{fn}$ de nuldeorde korrelaties van de statusfaktoren geslacht, leeft $1 \mathrm{jd}$ en soclale klasse met de index voor nadelige gevolgen weergegeven. U1t deze tabel bl1jkt dat:

- mannen vaker nadelige gevolgen ondervinden dan vrouwen

- Jongere mannen en vrouwen vaker nadelige gevolgen ondervinden dan oudere mannen en vrouwen

- noch bij mannen noch bij vrouwen er verschil is in nadelige gevolgen naar soclale klasse

Deze bevindingen leiden tot de in onderstaand schema weergegeven hypothesen.

bij kontrole of natelige navigen en honsumtie, horeme kurs s: 
Bif de hypothese over de invloed van geslacht moet een belangrijke kanttekening worden gemaakt. Garretsen (1983) presenteert gegevens waarult blljkt dat vrouwen vaker dan mannen verzwI Jgen dat ze afkeuring hebben ondervonden vanwege drankgebrufk. Alhoewel de gegevens van Garretsen uitsluitend betrekking hebben op Rotterdam, lijkt het me aannemelljk dat in het algemeen voor vrouwen de stap van het hebben van zorgen of ondervinden van afkeurIng, naar het in een vraaggesprek melden van deze zorgen of afkeuring groter is dan voor mannen. Immers, vermoedelijk is bif vrouwen de sociale druk om excessief drankgebruik te vermijden groter dan bif mannen. Deze kanttekening komt er in feite op neer dat het de vraag is of de gegevens waarover $1 \mathrm{k}$ beschik toetsing van de hypothese aangaande verschillen in afkeuring of zorgen tussen mannen en vrouwen toelaten.

Uit schema VIII kan worden afgeleid dat zorgen, afkeuring van familie en afkeuring van vrienden niet samengevoegd zullen worden tot één afhankelijke variabele. Hoewel de verwachting is, dat de invloeden van de onafhankelijke variabelen op deze drie afhankelijke variabelen dezelfde zijn, leek het me, zonder voorafgaande analyse, te voorbarlg om hier ook zonder meer vanuit te gaan. Het is op zifn minst voorstelbaar, dat famille drankgebrulk afkeurt, terwljl de drinker zich in het geheel geen zorgen maakt. Evenzo is het voorstelbaar, dat vrlenden volstrekt geen afkeurling laten blifken, terwljl de familie vindt dat er teveel gedronken wordt.

Uit het schema mag niet afgeleld worden dat een hypothese verworpen zal worden als niet voor alle drle de afhankelijke variabelen signifikante verschillen worden gevonden. Voor het verwerpen van een hypothese wordt als kriterium aangehouden dat ofwel bif geen van de drle afhankelifke varlabelen het verwachte verband wordt gevonden, dan wel dat er signifikante samenhangen zijn tegengesteld aan de hypothese. 
X. 2. Indicering van zorgen over en afkeuring van drankgebruik, en opzet van analyse

Zorgen over drankgebruik is op twee manteren geindiceerd:

- direct door een bevestigend antwoord op de vraag "maakt, $u$ zich wel eens zorgen over uw drankgebruik of heeft $u$ z1ch daar wel eens zorgen over gemaakt?"

- Indirekt namelifk als een respondent zelf ondervonden gevolgen van overmatig drankgebruik als symptomen van alkoholisme zlet. Het betreft hier de verschijnselen 1 maal per week of vaker dronken zijn of een kater hebben, niet kunnen stoppen met drinken, ruzle met de famille hebben over drankgebulk. Voor deze verschijnselen is zowel nagegaan of de respondent deze heeft ondervonden als nagevraagd of hif deze verschifnselen als tekenen van alkoholisme zlet.

Een respondent werd zorgen over $\mathrm{zIjn}$ drankgebruik toegekend als hif direct toegaf zorgen te hebben en/of zelf ondervonden verschijnselen als symptomen van alkoholisme ziet. De veronderstelling bif de laatste wijze van indiceren is dat lemand die zichzelf als alkoholist beschouwd, cok zorgen over zifn drankgebrulk heeft.

Bif de konstruktie van de variabele afkeuring door famille is gebrulk gemaakt van de volgende items:

- partner (Indlen ongehuwd ouders) hebben geklaagd over drinken;

- famille klaagde over drankgebruik;

- famille ergerde zich aan drinken;

- drank schadelifk voor situatie thuis.

Afkeurlng door vrlenden 1s door de volgende 1 tems geind1ceerd:

- mifn drinken was mede oorzaak van het verlies van een vrlendschap of van verwijdering tussen mij en mijn vrienden;

- vrienden vonden dat ik minder moest gaan drinken;

- drinken heeft schadelijke Invloed gehad op mijn vriendenkring.

Een respondent wordt geacht afkeuring van familie of vrlenden te hebben ondervonden als op éen of meer van de betreffende 1 tems bevestigend werd geantwoord. 
Er zl Jn derhalve drie dichotome varlabelen waarvan hleronder de frekwentle verdelingen zljn weergegeven.

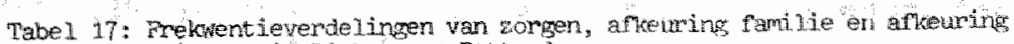
vriemen in Lanburg en Rot terdam

\begin{tabular}{|c|c|c|c|c|c|c|}
\hline & \multicolumn{2}{|c|}{ ZOROEN } & \multicolumn{2}{|c|}{ AFKEURINO RAMULIIE } & \multicolumn{2}{|c|}{ 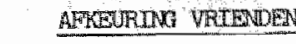 } \\
\hline & Limb. & R' dam & Litrb. & R'drT! & Iutim. & R'dam \\
\hline $\begin{array}{l}\text { Ja } \\
\text { Nee } \\
\text { Geen antwoon }\end{array}$ & $\begin{array}{c}10 \% \\
90 \% \\
-\end{array}$ & $\begin{array}{l}9.9 \% \\
90.18 \\
-\end{array}$ & $\begin{array}{r}8.5 \% \\
91.5 \% \\
-\end{array}$ & $\begin{array}{l}9.3 \% \\
90.7 \% \\
-\end{array}$ & $\begin{array}{r}2.48 \\
97.6 \% \\
0.6 \%\end{array}$ & $\begin{array}{r}3.0 \% \\
95.6 \% \\
1.4 \%\end{array}$ \\
\hline $\begin{array}{l}\text { Totazal } \\
N=\end{array}$ & $\begin{array}{l}100 \% \\
1545\end{array}$ & $\begin{array}{l}100 \% \\
1609\end{array}$ & $\begin{array}{l}100 \% \\
1545\end{array}$ & $\begin{array}{l}100 \% \\
1609\end{array}$ & $\begin{array}{c}100 \% \\
1545\end{array}$ & $\begin{array}{l}100 x \\
1609\end{array}$ \\
\hline
\end{tabular}

U1t de tabel wordt duldelljk dat afkeurlng door vrlenden beduldend minder vaak voorkomt dan zorgen of afkeurlng door famille. Wordt de verdeling van zorgen over of afkeuring van drankgebrulk naar geslacht nagegaan, dan b11jkt b1j vrouwen In Limburg en Rotterdam afkeuring door vrlenden slechts acht keer voor te komen. Vanwege dit kleine aantal is bif vrouwen de kans op afkeuring door vrienden nlet geanalyseerd.

Het lag in de bedoeling on in dit hoofdstuk dezelfde analysetechniek, als in het vorige hoofdstuk -anova- te gebrulken. Aangezien de afhankelijke varlabelen dichotoom zijn, is daarmaast een diskriminantanalyse uitgevoerd die, statisties gezien, adekwater geacht kan worden. De oorspronkelijke voorkeur voor Anova was ingegeven door zowel de wens enigge uniformitelt in analyse met voorgaande hoofdstuk aan te houden, alsook door de aanname dat er nauwelljks of geen verschillen in ultkomsten te zien zouden zifn tussen diskr1minant-analyse en Anova. Er bleken echter wel enlge verschlilen in ultkomsten te zljn. Blj mannen in Limburg bleek volgens de diskriminantanalyse de invloed van soclale klasse en strukturering van het dagelljks leven wél signifikant van invloed te $z 1$ In op de kans op zorgen en volgens de Anovaanalyse niet. Tevens bleek dat bij vrouwen in Limburg volgens de diskriminant-analyse strukturering van het dagelljks leven nlet van invloed te zlfn op de kans op zorgen en afkeuring van famllie, volgens de anova-analyse was er wel sprake van invioed. Gegeven deze in eerste instantie nilet 
verwachte sltuatle, is alsnog besloten de resultaten van de diskriminantanalyse te presenteren. Diskriminantanalyse moet immers bly het selekteren van varlabelen die bljdragen aan het onderscheld tussen twee groepen -in ons geval wel of geen zorgen of afkeurling- adekwater geacht worden dan Anova-analyse dle elgenlifk als els stelt dat de afhankelljke varlabele op intervalnivo wordt gemeten.

\section{3. Resultaten}

In alle analyses ziln de index voor nadellge gevolgen en konsumptienlvo als kontrole variabelen opgenomen. Blj de analyse naar de invloed van duur huldig drankgebrulk is tevens leeftijd als kontrolevarlabele opgenomen vanwege de hoge samenhang met duur van huldig drankgebrulk.

In tabel 18 z1 fn de resultaten van de diskriminantanalyse met betrekkling tot geslacht weergegeven.

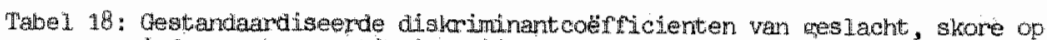

index en korsumptienivo bi,j zorgen en afkeuring door fanilie of ux"ienden

\begin{tabular}{|c|c|c|c|c|c|c|}
\hline & ZOROEN & & AFKEURING & VRTIWNDER & AFKEOURLWO & FAMCLIE \\
\hline Fhore op de index voor & Lant: & HCdam & $\operatorname{Limb}_{-\infty}$ & R'dan & 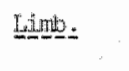 & B'datan \\
\hline nado llge gevolgen & 0.97 & 0.86 & 1.12 & 0.98 & 0.71 & 0.67 \\
\hline Konesungtuen wo & n.s. & 0.19 & -0.33 & n.s. & 0.43 & 0.42 \\
\hline Ges lachte (man'/vrouw) & n. & -0.08 & n.s. & n.s. & h.s. & -0.18 \\
\hline Canonusche korrelatie & $a+2.4$ & 0.51 & 0.30 & 0.44 & 0.43 & 0.53 \\
\hline
\end{tabular}

Geslacht is in Limburg op geen van de drle afhankelijke variabelen van Invloed, In Rotterdam op zorgen en afkeuring door famlite.

De richting van de invloed is echter tegengesteld aan de verwachting:

b11 mannen in Rotterdam is de kans op zorgen of afkeuring van famille hoger dan bij vrouwen in Rotterdam. In de dis- 
kussle zal een standpunt worden ingenomen of deze ultkomsten falsifikatie van de hypothese betekenen dan wel dat, zoals eerder is gesteld, de gegevens zich ntet lenen voor adekwate toetsing van de verschillen tussen mannen en vrouwen.

Terzljde wil $1 \mathrm{k}$ nog twee opmerkingen naar aanlelding van deze ultkomsten maken. Ten eerste bl1jkt in de meeste analyses konsumptienivo, onafhankelijk van de index voor nadelige gevolgen, bij te dragen aan een betere voorspelling van zorgen of afkeuring. Merkwaardig is de richting van de samenhang tussen konsumptienivo en afkeurlng vrienden bif mannen in Limburg. Na kontrole op de index voor nadelige gevolgen, neemt bif hoger konsumptienivo de kans op afkeurling vrlenden af. Ik vermoed dat de hoge samenhang tussen index voor nadelige gevolgen en konsumptienivo een rol speelt bif deze merkwaardige uitkomst.

Ten tweede blifkt dat in Rotterdam de canoniese korrelaties (waarvan het kwadraat te interpreteren is als maat voor verklaarde variantle) systematies hoger zifn dan in Limburg. Ult de hier niet weergegeven F-waarden in de 'sumary table' van de diskriminantanalyse blijkt dat de samenhang tussen Index voor nadelige gevolgen en zorgen of afkeuring in Rotterdam veel hoger is dan in Limburg. Anders gezegd: In Rotterdam is het moeilijker dan in Limburg onbekommerd nadellge gevolgen van drankgebruik te ondervinden.

In tabel $19 \mathrm{zi}$ in de uitkonsten met betrekking tot de invloed van leeftijd, soclale klasse en duur huldig drankgebruik weergegeven.

Ten aanzlen van leeftljd, kan de konklusle snel worden getrokken: er zljn geen slgnlflkante verschllien in kans op afkeuring of zorgen tussen jongeren en ouderen. De hypothese aangaande leeftijd moet worden verworpen.

Soclale klasse is in Rotterdan net van invloed. In Limburg, tegengesteld aan de verwachting, is deze faktor blif vrouwen van Invloed op zorgen en afkeuring van famille en bly mannen op zorgen. In de hogere soclale klasse is de kans op zorgen (mannen en vrouwen) en afkeuring door famille (vrouwen) groter dan in de lagere soclale klasse.

De hypothese dat er geen verschllien zijn naar gelang sociale klasse dlent te worden verworpen. 


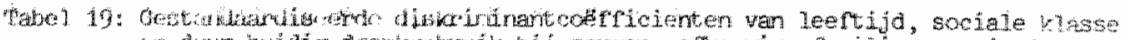

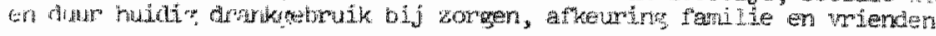

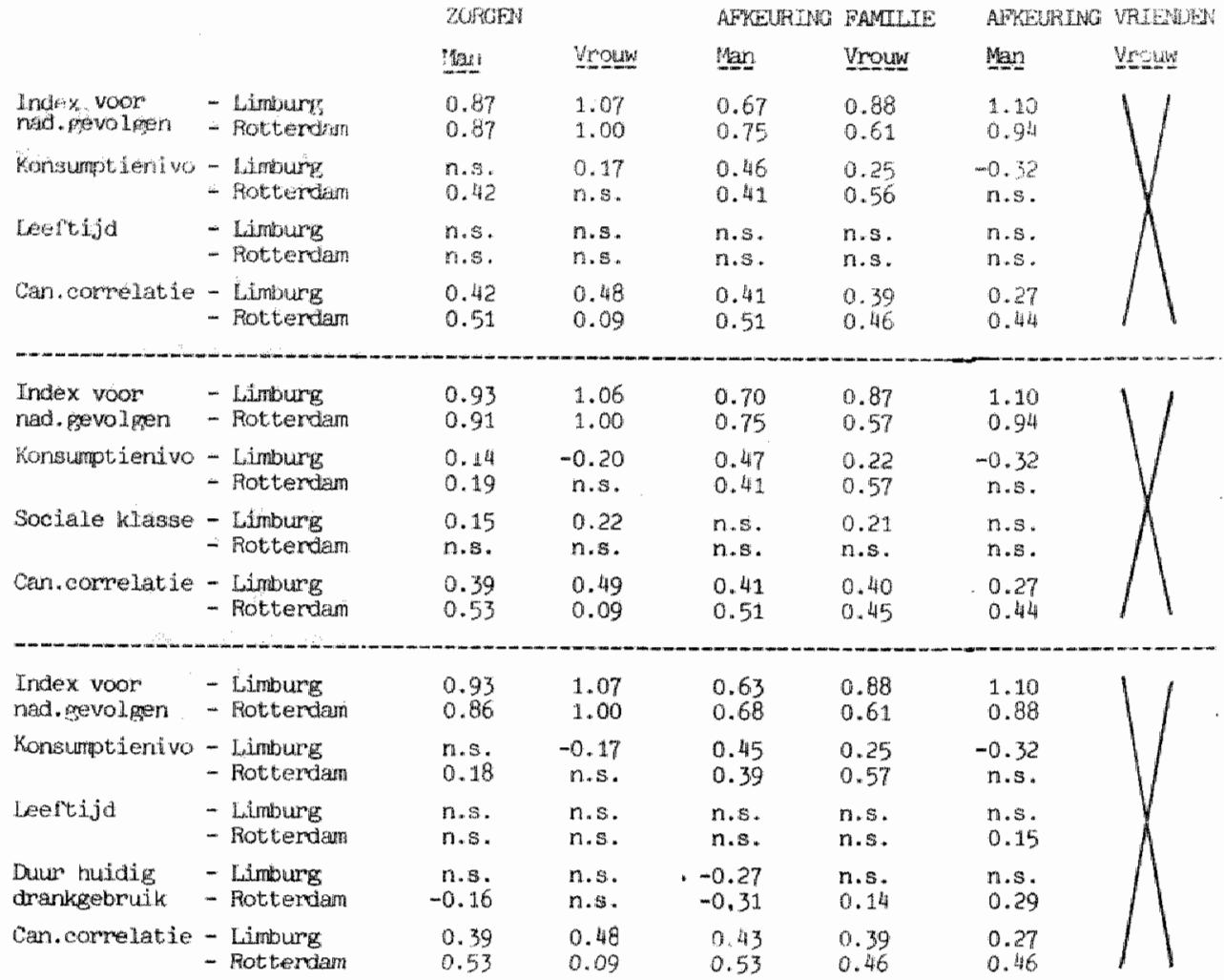

De invloed van duur van huldig drankgebruik is bif mannen anders dan bif vrouwen. BIJ mannen is er, tegengesteld aan de hypothese, sprake van een afname van de kans op afkeuring door familie (IImburg en Rotterdam), zorgen (Rotterdam) en afkeurlng door vrlenden (Rotterdam) bij langere van huldig drankgebrulk. BIf vrouwen in Rotterdam is er volgens verwachting sprake van een bif langere duur van huldilg drankgebrutk toenemende kans op afkeuring van familie. Er is hier derhalve sprake van tegengestelde uitkomsten, reden genoeg on de hypothese te verwerpen.. De uitkomsten laten echter wel een aarnemel1jk andere interpretatle toe. Daarop zal in de diskussie worden teruggekomen. 
Bif de analyse van de Invloed van strukturering van het dagelijks leven worden zowel samenhangen overeenkomstig als strijdig met de hypothese gevonden.

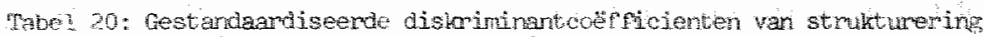
dagelijks bestaan, skore op indew en konsurptienivo bij zorgen en afkewing familie on vienden

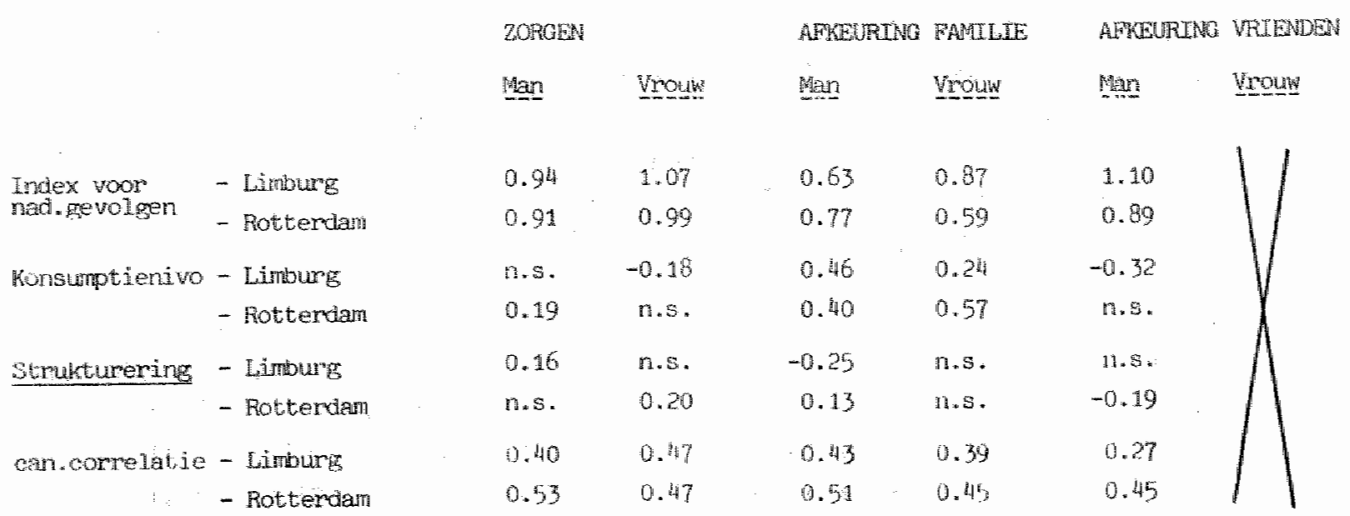

Overeenkomend met de hypothese is de bif een minder gestruktureerd dagelijks leven hogere kans op afkeuring van famille b1j mannen in Limburg en de hogere kans op afkeuring van vrienden bif mannen in Rotterdam. Tegengesteld aan de verwachting is dat bij een weinig gestruktureerd dagelijks leven de kans op afkeuring van familie geringer is bij mannen In Rotterdam. Dok hier kan, vanwege tegegestelde ultkomsten, de hypothese niet bevestigd worden geacht. Wat betreft zorgen kan worden opgemerkt dat, zo er signifikante verschillen naar gelang strukturering van het dagelijks leven zl.jn, deze tegengesteld zijn aan de hypothese, namelijk bif een meer gestruktureerd dagelljks leven 1s de kans op zorgen hoger bif mannen in Limburg en vrouwen in Rotterdam. Hiervoor is, weliswaar achteraf, een plausibele verklaring te geven, waarop in de diskussie zal worden teruggekomen.

Een merkwaardiger ultkomst betreft het felt dat een weinig gestruktureerd dagelijks leven bif mannen in Limburg leidt tot en hogere kans op afkeuring van familie, in Rotterdam tot een lagere kans. Dok hlerop zal in de diskussle worden teruggekomen. 


\section{4 Een nadere analyse}

Dok in dit hoofdstuk wordt, on dezelfde redenen als in het voorgaande hoofdstuk, een nadere analyse uitgevoerd van de invloed van stmukturering van het dagelijks leven, namelifk

- on na te gaan in welke mate de onderscheiden indikatoren voor strukturering van het dageliyks leven (arbeldsverplichtingen, partner en zorg voor thuiswonende kinderen) lelden tot verschillen in kans op zorgen of afkeuring - om bij werk- en gezinssituatie na te gaan of het ontbreken van een maatschappelifk normaal geachte rol, in sterkere mate van invloed is dan het op andere wijze ontbreken van dagelijkse verplichtingen

De analyses $z 1 \mathrm{fn}$ om twee redenen uftgevoerd met behulp van anova. Ten eerste is er een sterke interaiktle tussen de onderschelden indikatoren voor stmukturering van het dagelljks bestaan, wardoor diskriminantanalyse nlet geschikt 1s. Ten tweede zijn werk- en gezinssituatie nominale varlabelen die in de vorm waarin ze hier gebmukt worden, niet in een diskriminantanalyse opgenomen mogen worden. Aangezlen het hier niet gaat om toetsen van hypothesen, maar om het exploreren van samenhangen is er mljns inzlens hler geen bezwaar tegen het gebruik van anova.

De uitkonsten betreffende de mate waarin de onderschelden Indikatoren voor strukturering van het dagelifks leven blydragen aan verschillen in zorgen of afkeuring, is in onderstaand schema weergegeven.

De voornaanste konklusle 1s:

- het ontbreken van een partner is lets vaker direkt van Invloed dan het ontbreken van werk of zorg voor thuiswonende kinderen. Terzljde $z 1 \mathrm{f}$ opgenerkt dat de richting van de invloed van zorg voor thulswonende kinderen bij vrouwen in Rotterdam, tegengesteld is aan de hypothese. Indien men voor thulswonende kinderen zorgt, is de kans op zorgen namel1 jk groter. 
Sohenz IX: Iyvioed wan wert parther en zorng wor thuiswonende Kinderen op zorgen of afkeuring; kontrole or natelige gevoligen en konsumptieniwo en leeftiju

\begin{tabular}{|c|c|c|c|c|}
\hline . & $\begin{array}{l}\text { ZOROEN } \\
\text { Limbure }\end{array}$ & & Rote & \\
\hline & man & vroulat & & Wrotwa \\
\hline $\begin{array}{l}\text { - werk } \\
\text { - parmer } \\
\text { - zor }\end{array}$ & $\begin{array}{l}n_{u} s . \\
p \times 0.05 \\
n_{.5} .\end{array}$ & $\begin{array}{l}\text { n.s. } \\
\text { n.s. } \\
\text { n.s. }\end{array}$ & $\begin{array}{l}\text { M.s. } \\
\text { n.s. } \\
\text { n.s. }\end{array}$ & $\begin{array}{l}n .5 . \\
n .5 . \\
p<0.05\end{array}$ \\
\hline
\end{tabular}

In interalkie unet andere indikator (en):

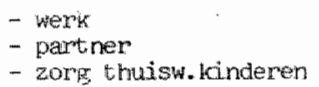

$\begin{array}{llll}p+0.05 & \text { n.s. } & \text { p.0.05 } & n . s . \\ \text { n.s. } & \text { n.s. } & \text { n.s. } & n<0.05 \\ \text { n.s } & \text { n.s. } & \text { n.s. } & \text { n.m. }\end{array}$

AFWEUTCNG FAMLLIL Limburg

Fotterdam

Dinekte Invlogden:

- werl

- partner

- zorg thuisw. kinderen

$\begin{array}{llll}\text { n.s. } & \text { n.s. } & \text { n.s. } & \text { n.s. } \\ \text { p<0.05 n.s. } & \text { p<. } & \text { n.05 } & \text { n.s. } \\ \text { n.s. } & \text { n.s. } & \text { n.s. } & \text { n.s. }\end{array}$

In interaktie met andere indikator (en):

- werto

- partiner

- zorg thisisw. kinderen

$\begin{array}{llll}\text { n.s. } & \text { n.s. } & \text { n.s. } & \text { m.s. } \\ \text { n.s. } & \text { n.s. } & \text { n.s. } & \text { n.s. } \\ \text { n.s. n.s. } & \text { n.s. } & \text { n.s. }\end{array}$

AFKETRTME WRITYNDEN Laimbures

Potiteriam

Direlste inwioeden:

- werk

- vontrier

- Rong thuisis . Kinderen

$\begin{array}{ll}\text { n.is. } & \text { n.s. } \\ \text { n.s. } & \text { n.s. } \\ \text { n.s. } & \text { n.s. } \\ & \\ & \\ \text { n.s. } & \text { n.s. } \\ \text { n.s. } & \text { n.s. } \\ \text { n.s. } & \text { n.s. }\end{array}$

D. $<0.05: x$

TH: $x$

In interahtie met andlere indukator (erv):

- werk
- partner.
- gorg thuisw kinderan

n.s. n.s. n.s.

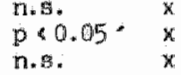

De analyse met betrekking tot verschillen in zorgen of afkeurlng naar gelang werk- en gezinssituatie, is alleen voor mannen uttgevoerd. BIf vrouwen $\mathrm{zIjn}$, zoals hiervoor bleek, werk en partner niet direkt van invloed. In onderstaand schema $\mathrm{zl}$ fn de resultaten schematles weergegeven (zle ook tabel 13 in b1.jl. I.) Indien er sprake was van 
zeer kleine verschillen, is een zelfde rangnumer toegekend.

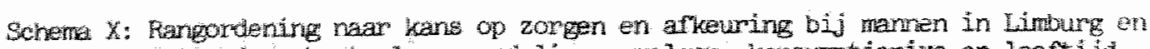
Rotterdain; Kontrole op rardelige gevolgen, konsumptieniwo en leeftijo.

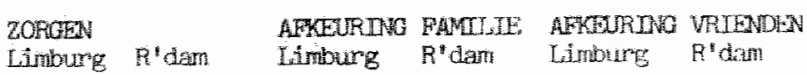

Wegkituatie

$\begin{array}{lllllll}\text { - werkt } & \text { n.s. } & \text { n.s. } & \text { n.s. } & 2 & \text { n.s. } & 2 \\ \text { - werkzoekend } & \text { n.s. } & \text { n.s. } & \text { n.s. } & 3 & \text { n.s. } & 1 \\ \text { - arbeidsongesschikt } & \text { n.s. } & \text { n.s. } & \text { n.s. } & 2 & \text { n.s. } & 2 \\ \text { - gepensioneerd } & \text { n.s. } & \text { n.s. } & \text { n.s. } & 1 & \text { n.s. } & 2\end{array}$

Gezingsitugatie

- met pantiner

- noolit gehulud

- gesche Iden

- weduwnear

$\begin{array}{ll}\text { n. } . ~ & 3 \\ \text { n.s. } & 2 \\ \text { n. } & 1 \\ \text { n.s. } & 4\end{array}$

$\begin{array}{lll}1 & \text { n.s. } & 2 \\ 2 & \text { n.s. } & 2 \\ 3 & \text { n.s. } & 1 \\ & \text { n.s. } & *\end{array}$

* =n Le klein voor konklusies

* = tevens kontrole op socilale klasse

$1=$ hoogsto kans op zorgen of aflowang

De volgende konklusles zljn mogel1jk:

- In Rotterdam is de kans op afkeuring van vrlenden groter bif het ontbreken van een maatschappel1jk normaal geachte arbelds- of gezinsrol (werkzoekend, arbeldsongeschikt, geschelden) dan b1f het op andere wijze ontbreken van een arbelds- of gezinsrol;

- In Limburg is bly gescheldenen de kans op zorgen en afkeuring famllie hoger dan blf noolt gehuwden.

Er zijn derhalve aanwljzIngen dat het ontbreken van een maatschappe 11.Jk normal. geachte rol in sterkere mate de kans op zorgen of afkeuring verhoogd dan het op andere wljze ontbreken van rol(1en) die het dagel1jks leven struktureren. Er moet echter ook gewezen worden op de uitkomst in Rotterdam: blf werkzoekende en gescheiden mannen blijkt de kans op afkeurlng door faml11e lager te $z 1$ Jn dan b1j de andere kategorleèn.

Deze uitkomst is geen reden de eerder gedane ultspraak te herroepen. Wel doet zlch de vraag voor op welke punten met name geschelden mamen in Limburg en Rotterdam dusdanig verschlllen dat de resultaten zo tegengesteld aan elkaar kumen zifn. 
Samenvatting en diskussle

In onderstaand schema is aangegeven welke samenhangen zifn gevonden en voor welke hypothesen steun is gevonden.

Schema XI: Inwloeden op zorzen, ancuridis familie en afheuming vrienden.

\begin{tabular}{|c|c|c|c|c|c|c|c|c|c|c|c|c|c|}
\hline & \multicolumn{2}{|c|}{ 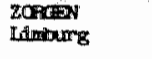 } & \multicolumn{2}{|c|}{ Rottiendain } & \multicolumn{4}{|c|}{ 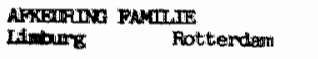 } & \multicolumn{4}{|c|}{ 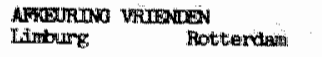 } & \multirow[t]{2}{*}{ 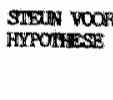 } \\
\hline & men: & whoum & man & vrour & $\operatorname{man}$ & moun: & man & vroum & man & vroun & $\operatorname{man}$ & noun & \\
\hline 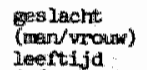 & 0 & 0 & - & - & o & 0 & - & - & 0 & $a$ & 0 & o & nee \\
\hline 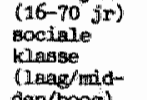 & 0 & o & 0 & 0 & 0 & 10 & 0 & 0 & 0 & 0 & 0 & 0 & ne \\
\hline 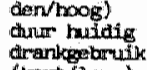 & 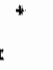 & + & 0 & 0 & $\circ$ & + & 0 & 0 & 0 & $x$ & o & $x$ & nea \\
\hline 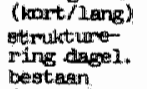 & 0 & 0 & - & 0 & - & 0 & - & * & 0 & $x$ & - & $x$ & nee \\
\hline (Iese/hoog) & + & 0 & 0 & \# & - & 0 & + & 0 & 0 & $x$ & - & $\mathrm{x}$ & net \\
\hline
\end{tabular}

+ I toenamie wan kans bij hogere akore

$a=$ versochil

- = afmenende kans bij thogere skore

$x=$ analyae niet wit tgevoerd

Voor geen van de hypothesen is voldoende steun te vinden, een op zlch opmerkelifk, zij het onbevredigend, resultaat. ook al onbevredigend te noemen, omdat de samenhangen dle zifn gevonden slechts in beperkte mate toelaten, los van de hypothesen, konklusies te trekken die voor belde reglo's geldig zijn. Behalve de invloed van de skore op de index voor nadelige gevolgen zijn er slechts twee andere faktoren waarvoor met enige duidelijkheld konklusies getrokken kunnen worden:

- Leeft1jd heeft geen enkele invloed op de kans op zorgen of afkeuring.

- De invloed van duur huidig drankgebrutk op zorgen of afkeuring is bif mannen in Limburg en Rotterdam tegengesteld aan de verwachting: bif kortere duur van huldig drankgebrulk is er een hogere kans op zorgen en afkeuring van familie en vrienden. 
De samenhangen die voor andere faktoren $\mathrm{z} 1 \mathrm{fn}$ gevonden laten geen duldelljke konklusles toe die voor belde reglo's geldig zifn. Wordt er meer speclflek op de resultaten ingegaan, dan zijn er voor bepaalde resultaten nog wel plausibele verklaringen te geven.

\section{Geslacht}

Wat betreft de invloed van geslacht werd voor Rotterdam gevonden dat bly mannen de kans op zorgen en afkeuring van famille hoger 18. Toch ben 1k niet geneigd hieraan de konklusie te verbinden dat, b1f overeenkomstige mate van nadelige gevolgen, de kans op zorgen en afkeuring bij mannen inderdaad hoger is dan bij vrouwen. M1Jns inziens is het reèler om te besluiten dat de gegevens warmee hier wordt gewerkt geen geldige konklusles aangaande verschillen in zorgen of afkeuring tussen mannen en vrouwen toelaten. Hiervoor heb ik twee redenen. Eén daarvan is al eerder genoemd; bif vrouwen is de onderrapportage van kritiek utt de ongeving waarschf fnlljk groter dan b1j mannen (Garretsen, 1983). De tweede reden is, dat vrouwelijke probleendrinkers, vergeleken met hun aandeel in een populatie probleemdrinkers geldent1flceerd in een representatief onderzoek, oververtegenwoordigd zljn b1f de hulpverlenende instellingen (Knibbe, 1982). Kritlek utt de angeving is blijkens ander onderzoek (Hingson e. a 1980,1982 ) de voornaamste reden om hulp b1j profess1onele hulpverleners te zoeken. Vanult dit perspektief bezlen moet het hoogst onwaarschijnlijk worden geacht dat vrouwen -b1f overeenkomstige mate van nadelige gevolgen- minder krit1ek of zorgen zouden ondervinden.

\section{Leeftijd}

Zoals gezegd, is er ten aanzien van de invloed van leeftijd een duldell fke konklusle mogelljk: er z1jn geen verschillen tussen jongeren en ouderen wat betreft zorgen of afkeuring. Klaarblijkelljk is er hler sprake van een konsensus over de onwenselljkheld van nadelige gevolgen waarop de soms grote verschtllen tussen jongeren en ouderen in nadelige gevolgen van drankgebrulk niet van invloed 1s. Naar mijn mening mag dit een opvallend resultaat genoemd worden. 
Soclale klasse

Er werden geen verschillen in zorgen of afkeuring naar soclale klasse verwacht. In Limburg blijkt echter de kans op zorgen (mannen en vrouwen) en afkeuring van famllle (vrouwen) groter te zifn in de hogere klasse.

Voor de in Limburg en Rotterdam verschillende Invloed van sociale klasse bij vrouwen $1 \mathrm{~s}$, naar $1 \mathrm{k}$ meen, een plausibele verklaring te geven.

In hoofdstuk VI bleek dat in Rotterdam en Limburg in de hogere soclale klasse het verschil in drinkpatroon tussen mannen en vrouwen het kleinst is. Op grond van t1jatrend anaIyses (van Reek e.a., 1983) kan gesteld worden dat dit in de hogere klasse kleinere verschil in drinkpatroon de ultkomst is van een emanclpatieproces voor vrouwen dat zich tot nu toe beperkt heeft tot de hogere soclale klasse. In Rotterdam kan blijkens de resultaten van hoofdstuk VI dit emanc1patieproces wat betreft de hogere klasse als voltoold worden beschouwd. In Limburg daarentegen zi.jn er ook in de hogere klasse nog steeds aanzienlijke verschillen in drinkpatroon tussen mamnen en vrouwen. BIf vrouwen ult de hogere klasse in Limburg is er, vergeleken met Rotterdam, nog sprake van het verwerven van rechten op andere vormen van drankgebrulk dan tot nu toe 'gepast' werden geacht. Voorstelbaar is dat in zo'n situatie vaker zorgen gevoeld worden of af'keuring geult dan in een situatie warin deze rechten onomstreden zijn.

Voorgaande redenering kan in de volgende hypothese worden vastgelegd:

in populaties war sprake is wan een emancipatieproces aangaande drankgebruik is -bij kontrole op de mate watrin nadelige gevolgen van drankgebruik worden ondervondende kans op zorgen of afkeuring van familie groter dan in poputaties war ofwel de bestaande verschitzen in drankgebruik geaksepteerd worden, ofwel de verschillen grotendeels aijn opgeheven.

Ik heb geen verklaring voor de uitkomst dac in Limburg mannen in de hogere klasse vaker zorgen ontrent drankgebrulk ondervinden dan marnen in de midden- of lagere klasse en in Rotterdam nlet.

\section{Duur huldig arankgebrutk}

Betreffende de Invioed van duur van huldig drankgebrulk, kan er voor mannen een duidelljke konklusle worden geformuleerd, 
zif het dat deze konklusle tegengesteld is aan de hypothese. B1 I langere duur van huldilg drankgebrulk neent b1j mannen de kans op afkeuring van familie (Rotterdam en Limburg), zorgen (Rotterdam) en afkeuring van vrlenden (Rotterdam) af. BIJ vrouwen wordt slechts één keer een samenhang gevonden overeenkonstig de oorspronkelijke hypothese: een toename van de kans op afkeuring van famille bij vrouwen in Rotterdam.

De oorspronkel1fke gedachte, dat b1j langere duur van excesslef drankgebmulk de angeving steeds duldelljker laat merken dit drankgebmulk onaanvaardbaar te vinden, blijkt wat betreft mannen nalef te $\mathrm{zI}$ In. Nalef omdat, gegeven het ontbreken van heldere en gedeelde normen, de legltimitelt van kr1tlek op drankgebrulk alt1.jd bestreden kan worden. Klaarbl1 jkel1.k treedt er bly langere duur van excessief drankgebruik niet duldel1 Jk een proces van ultstoten op, maar van de kant van de famille akseptat1e en mogel1.jk onversch1l11gheld en van de kant van de drinker een selektle van vrlenden en kennissen waarmee de kans op afkeuring wordt geminimaliseerd. In een eerdere publikatle is er op gewezen dat probleemdrinkers vaker dan nlet-probleemdrinkers zeggen vrlenden of kennissen te hebben die ze als alkohollst beschouwen (Knibbe, 1982).

Als nleuwe hypothese wll tk dan ook formuleren:

bij mannen neemt bij langere duur van drankgebruik

gepaard gaande met nadelige gevolgen, de kans op

zorgen en afkeuring van familie of viienden af".

Voor vrouwen is er, gezlen de verwachte hogere kans op afkeuring van fam1lie in Rotterdam geen reden de oorspronke11. kke hypothese te verwerpen. Op zich is ook aannemel1jk dat b1 1 vrouwen, anders dan b1f mannen, bif langere duur van drankgebrulk gepaard gaande met nadelige gevolgen de omgeving zlch steeds sterker uitspreekt tegen dit drankgebrutk. Immers bly vrouwen behoort excesslef drankgebrutk in sterkere mate dan blj mannen tot de ultzonderlngen, en naar $1 \mathrm{k}$ aanneem, draagt dit ertoe bij dat anderen zlch minder verpllaht voelen terughoudend met krltlek te zljn. Wel dient opgemerkt te worden, dat er blj vrouwen slechts zeer beschelden steun voor de oorspronkellfke hypothese $1 \mathrm{~s}$ te vinden, aangezien van de vier keer dat er een samenhang kon worden gevonden, er slechts één keer een slgniflkant versch11 optreedt. 
Strukturering van het dage11 jks bestaan

BIJ de relatle tussen strukturering van het dagelljks be staan en de kans op zorgen en afkeurtng van famllle en vrienden trekt één punt de meeste aandacht: b1j mannen in Rotterdam een kleinere kans op afkeuring van familie blj een weinig gestruktureend dagelijks leven, b1 $\mathrm{J}$ mannen in Limburg een hogere kans.

Ik wil echter beglnnen met de bespreking van de samenhang tussen strukturering van het dagel1jks bestaan en respektievel1.jk zorgen en afkeuring van vrienden.

In de tweede populaties (mannen in Limburg en vrouwen in Rotterdam) waar sprake is van een signiflkant verschil in zorgen naar gelang strukturering, is sprake van een lagere kans op zorgen b1f mensen met een weinig gestruktureerd dagel1jks leven. Dit is tegengesteld aan de hypothese. Ter

verklaring van deze ultkonst, kan aangevoerd worden dat b1j een meer gestruktureerd dagel1 jks leven de mogel1 jke komsekwenties van drankgebrulk naar partner, kinderen, werk evenzovele bronnen van zorgen kunnen zifn.

Anders gezegd: waarschifnl1jk neent de kans op zorgen toe, naarmate de drinker het mogel1 jk acht dat meer mensen uit zijn dagel1jkse angeving zich storen aan zijn drankgebrulk. om voorgaande redenering om te zetten in een nleuwe hypothese moet de veronderstelling dat een varlabele in princlpe op dezelfde wljze van invloed is op zorgen, afkeuring door $\mathrm{fa}-$ milie en afkeuring vrlenden worden losgelaten. De nieuwe hypothese die dan mogel1 $1 \mathrm{k}$ wordt, luldt als volgt:

narmate het dagelijks teven sterker gestmiktureerd

is zat -bij kontrole op de mate warin nadelige ge-

Dolgen wan drankgebmitk worden ondervonden-de kans

op zorgen over drankgebrulk toenemen.

Wat betreft afkeuring van vrlenden wordt In Rotterdam, echter nlet in Limburg, de verwachte samenhang gevonden: een hogere kans 11 een minder gestruktureerd dage11,1ks leven. Nadere analyse maakt duldel1,jk dat deze hogere kans met name geldt b1j het ontbreken van een maatschappelljk nomaal geachte rol 1.c. gescheldenen, werkzoekenden en arbeldsongeschikten.

De voor IImburg en Rotterdan tegengestelde ultkomsten aangaande de Invloed van strukturering op affeuring door fami11e, kumen worden toegespltst. In Limburg bl1jken vooral de gescheldenen een verhoogde kans op afkeuring voor famille te ondervinden en worden voor werkzoekenden geen slgniflkante 
verschlllen met werkenden gevonden. In Rotterdam bl1 Jken gescheldenen en werkzoekenden een geringere kans op af"keuring door famlle te ondervinden.

Voor werkzoekende mannen is nog nagegaan of deze, vergeleken met werkende nannen vaker opgaven dat hun partner veel dronk, of dat ze familleleden als alkohollst beschouwen. Belde gegevens zlin te beschouwen als (onvolmaakte) Ind1katoren voor binnen gezins- en familleverband heersende excessleve drinkgewoonten. Er blifken op deze twee punten echter geen relevante verschillen te bestaan. Ik heb dan ook geen verklaring voor dit versch1l tussen Rotterdam en Limburg.

De vergel1jking van werkzoekenden en, in dit geval ook gescheldenen met respektlevelifk werkenden en gehuwden op het punt van het kennen van alkohollsten leverde wel een ander detall op dat waard is on vermeld te worden. In Rotterdam, echter niet in Limburg, geven gescheiden en werkzoekende mannen vergel1jkenderwi Is vaker op vrlenden of kennissen als alkoholist te beschouwen. Dit gegeven gekombineerd met de hogere kans op afkeurlng door vrlenden b1j gescheldenen en werkzoekenden betekent naar ik aanneem dat met name bil gescheldenen en werkzoekenden in Rotterdam blj langere duur van excesstef drankgebrulk een vernauwing van de vrlenden en kennissenkring optreedt tot degenen die ook excessief drinken.

In onderstaande flguur $z 1 \mathrm{Jn}$ de resultaten van dit hoofdstuk nog eens weergegeven met toevoeging van de nieuwe hypothesen.

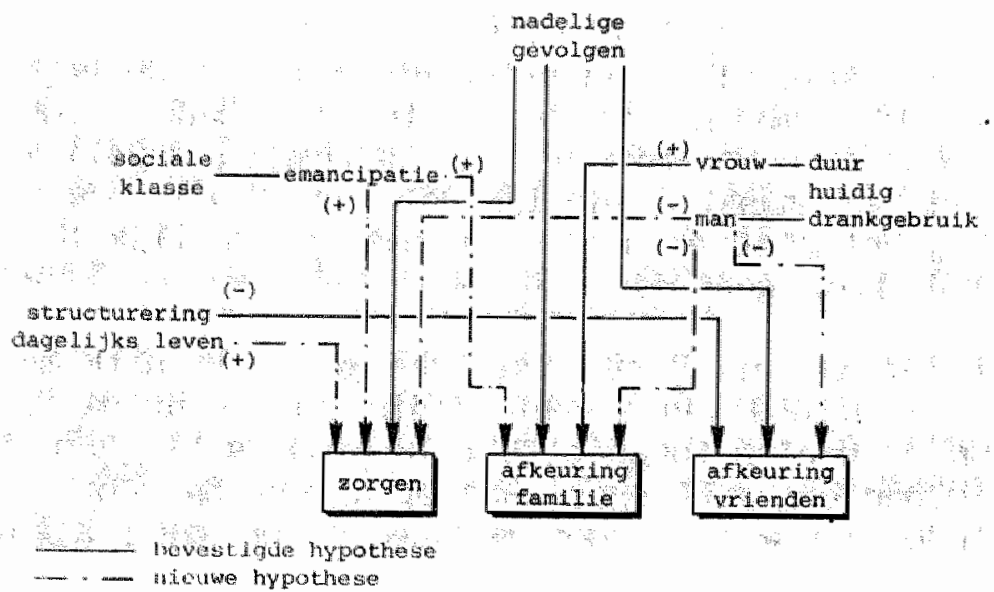




\section{Samenvatting en slotbeschouwing}

Het grootste deel van dit hoofdstuk zal in beslag genomen worden door een samenvattende bespreking van de resultaten. Naast deze samenvatting wil ik in dit hoofdstuk nog de volgende punten ter sprake brengen:

- de mate waarin voor de onderscheiden indikatoren van strukturering van het dagel1jks bestaan afzonderl1jk samenhangen met de afhankelijke varlabelen worden aangetroffen,

- de corzakelljkheid van de gevonden samenhangen, een probleem dat met name de samenhang tussen intensivering van drankgebruik en strukturering van het dagelijks bestaan betreft,

- de geldigheld van de gevonden samenhangen gegeven de onderschatting van alkoholkonsumptie,

- mogelifke beleldsimplikaties van de in deze studie gepresenteerde resultaten.

XI. 1. Samenvatting van de studie

Bif de samenvattende bespreking zal het hieronder weergegeven figunur als leidraad dienen. $\mathrm{Er}$ zal niet per probleemstelling besproken worden welke samenhangen verwacht en aangetroffen zljn. Als Invalshoek van de bespreking wordt aangehouden hoe één faktor (b1j statusfaktoren: een gelljksoortige serle faktoren) van invloed is op de onderschelden momenten dle het proces van gangbaar tot problematles drankgebrutk markeren.

Gangbare drinkpatronen

om twee, elkaar aarvul lende redenen, werd verwacht dat het drinkgedrag van Individuen, ondanks het ontbreken van gedeelde normen aangaande drinkgedrag, samenvattend beschreven kan worden in enkele gangbare drinkpatronen:

individuen zijn genelgd anderen na te volgen on een riskante gewoonte als alkoholgebmulk een betekenlsvolle plaats in hun leefwljze te geven,

- vanult de samenleving bezlen is het van belang dat in- 
dividuen op een herkenbare en sociaal akseptabele wijze van de vrijheld on alkoholhoudende drank te drinken gebruik maken. Deze herkenbaarheld veronderstelt dat er enige uniformiteit in drinkgedrag 1s, 1.c. dat het drinkgedrag zlch laat beschrljven in enkele drinkpatronen. (De sociale aanvaardbaarhe1d van gangbare drinkpatronen, moet overgens los gezlen worden van de vraag naar de mate waarin gangbare drinkpatronen leiden tot nadelige gevolgen van drankgebrilk).

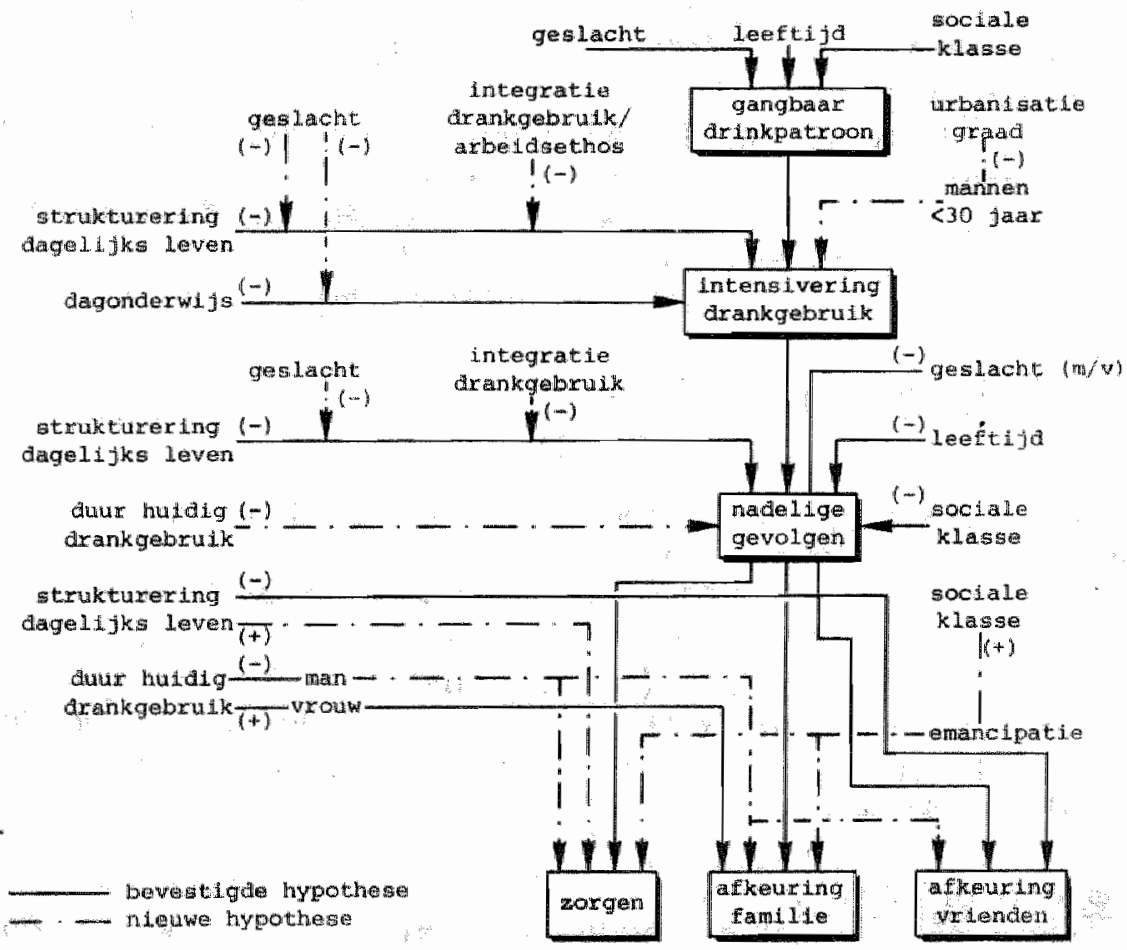

De hypothese dat de verscheldenheld aan individueel drinkgedrag in enkele drinkpatronen samengevat kan worden, tran bevestigd worden geacht. Twee gangbare drinkpatronen, incldenteel mat1g drankgebrulk en b1 jna dageli jks thuis drinken komen zowel in Limburg als in Rotterdam voor. Perlodiek veel 
drinken, gekenmerkt door een vergelijkenderwijs hoge konsumptie op weekenddagen, kan alleeen in Limburg tot de gangbare drinkpatronen worden gerekend. Het als 'mengvorm' benoemde drinkpatroon komt alleen in Rotterdam voor. Laatst genoemd drinkpatroon onderscheldt zich door een lets hogere frekwentle van drankgebruik dan incidenteel matig drankgebruik, en een rulm lagere frekwentle dan dagelljks thuls drinken. Vergeleken met de andere drinkpatronen, is de mengvorm een minder karakteristleke wijze on drankgebrulk in het leefpatroon op te nemen.

Status faktoren van invloed op gangbaar drinkpatroon.

Er werd verwacht dat deze gangbare drinkpatronen niet gel1.jk verdeeld zouden $\mathrm{z} 1 \mathrm{jn}$ over verschillende bevolkingsgroepen. Er kunnen namel1jk statusrolverwachtingen zijn die aanwlyzingen inhouden welke gangbare drinkpatronen niet geschikt worden geacht en welke wel.

Er bleken Inderdaad verschilien in drinkpatroon te zi.jn tussen statusgroeperingen gedeflniëerd in temen van geslacht, leeftijd en soclale klasse. De voomaamste verschllien zijn:

- Incidenteel matig drankgebrulk komt blj vrouwen in LImburg en Rotterdam veel vaker voor dan bif mannen.

- perlodiek veel drinken (L1mburg) en de mengvorm (Rotterdam) komt bif Jongeren, en meer speciflek bij Jongere mannen, vaker voor dan bif ouderen.

- b1Jna dagel1jks thuis drinken komt vaker voor in de hogere sociale klasse dan in de lagere soclale klasse.

In Limburg z1jn, vergeleken met Rotterdam, de statusrolverwachtingen over welk van de gangbare drinkpatronen het meest wenselijk is, duldelijker. Tevens bevat het drinkpatroon perlodlek veel drinken duldelljker aanwIJzIngen hoe drankgebrutk in het leefpatroon op te nemen dan de mengvorm in Rotterdam. Belde ultkomsten tezamen leldden tot de konklusie dat het drankgebruik in LImburg sterker geintegreerd 1s. Deze konklusle maakt het mogel1.jk nog te bespreken verschtlien in u1 tkonsten tussen Limburg en Rotterdam te interpreteren.

Voorzover verschillen in drinkpatroon ook verschilien in konsumptienivo impliceren (hetgeen overigens bij de in deze studie aangehouden omschrljving van gangbaar drinkpatroon niet per definitie het geval hoeft te zilfn), zullen met 
drinkpatroon samenhangende statuskermerken ook lelden tot verschlllen in konsumptlenlvo. Deze verschillen in konsumptienlvo moeten echter gerekend worden tot de in een samenleving normaal geachte verschilien in drankgebrulk en mogen derhalve nlet geinterpreteerd worden als "Intenslvering" van drankgebruk. Om die reden staan de statusfaktoren ntet aangegeven in het schema blj intensivering van drankgebmulk.

\section{Statusfaktoren en nadelige gevolgen.}

Geslacht, leeft1jd en soclale klasse werden wel van Invloed geacht, ook na kontrole op konsumptientvo, op nadelige gevolgen van drankgebrutk. De reden voor deze verwachting was, dat er, afhanke $11 \mathrm{Jk}$ van drinkpatroon, verschlllen $\mathrm{z} 1 \mathrm{jn}$ in de wifze waarop een overeenkomstige hoeveelheld drank wordt gebrulkt. B1jvoorbeeld, 20 glazen per week kan betekenen dat er ledere dag bijna drle glazen wordt gedronken of dat er op zaterdag en zondag ledere keer 10 glazen wordt gedronken en op de andere weekdagen niets. B1j het laatste drinkpatroon moet de kans op de hler onderzochte nadelige gevolgen van drankgebrutk hoger worden geacht.

Geslacht blijkt van invloed te zljn op de kans op nadelige gevolgen, ook als gekontroleerd wordt op konsumptientvo, echter in rlahting tegengesteld aan de op grond van de verschillen in drinkpatroon tussen mannen en vrouwen te verwachten richting. Bif mannen is de kans op nadelige gevolgen hoger. De oorzaak hlervoor werd gezocht in het felt dat drankgebrulk bif mannen tot de meer vanzelfsprekende gewoonten behoort.

Daarom $11 \mathrm{jkt}$ het me aannemel1 jk dat mannen vaker dan vrouwen op onregelmatige t1 jdstippen dusdanig drinken dat zich nade11ge gevolgen van drankgebrulk voordoen. Dit drankgebrulk wordt nlet of nauwel1 $\mathrm{ks}$ gereglstreerd met vragen naar gemiddelde konsumptie of konsumptle in de afgelopen week, maar leldt wel tot nadellge gevolgen.

De invloed van leeft IJ op nadelige gevolgen van drankgebrulk, is duldelifk aantoonbaar: voor jongeren is, bij overeenkomstig konsumptienlvo, de kans op nadelige gevolgen hoger dan voor ouderen. De rlchting van de samenhang kan ook afgeleld worden ult de verschtllen in drinkpatroon tussen Jongeren en ouderen. BI Jongeren domineren drinkpatronen met een beperkte frekwentie van drankgebrulk waardoor, b $1 \mathrm{j}$ een overeenkomstlg aantal glazen, de hoeveelheld die per keer wordt gedronken hoger is. 
Dok tussen de onderschelden sociale klassen $z 1 . j n$ er verschillen in de mate waarin blf overeenkonstig konsumptienivo drankgebrulk leldt tot nadelige gevolgen. Deze verschillen zijn echter minder sterk dan de verschillen naar leeftijd. Voor mannen in Rotterdam werd dit verschil, gezlen het ontbreken van verschillen in drinkpatroon naar soclale klasse, niet verwacht. Mede op grond van de literatuur, kan vermoed worden dat er in de lagere sociale klasse, ook los van een dominant drinkpatroon, vaker incidenteel ormatig drankgebrulk voorkont dan in de hogere klasse.

Statusfaktoren en zorgen of afkeuring.

ondat in statusgroeperingen gedefinieerd naar geslacht, leeftijd en soclale klasse, drankgebruik in verschillende mate gepaard gaat met nadelige gevolgen, was de verwachting dat de afkeurenswaardigheld van nadelige gevolgen ook zou verschillen naar gelang statusgroepering. Immers in statusgroeperingen waar drankgebrulk vergelijkenderwljs vaak leldt tot bv. symptomen als tremoren en dronkenschap, is dit een minder opvallend verschifnsel en on die reden minder aanlelding voor zorgen, afkeuring van famllie of vrlenden, dan in statusgroeperingen waar drankgebrulk maar zelden gepaard gaat met nadelige gevolgen.

Wat betreft geslacht werd voor Rotterdam vastgesteld dat deze faktor, ook na kontrole op nadelige gevolgen van drankgebrutk, van invloed is op zorgen en afkeuring van familie. Toch staat de faktor geslacht niet in het schema vermeld. De reden daarvoor is niet dat alleen in Rotterdam een samenhang wordt gevonden. Wel dat de rlchting van de samenhang, namelifk mannen een hogere kans op zorgen en afkeuring door familie, volstrekt tegengesteld is aan de verwachting. Mede op grond van het door Garretsen (1983) gekonstateerde felt dat b1f vrouwen de onderrapportage van kritiek uit de omgeving groter is dan bif mannen, acht $1 \mathrm{k}$ het wljzer te besluiten dat de hier gebruikte gegevens geen geldige konklusles toelaten aangaande verschillen tussen mannen en vrouwen in kans op zorgen of afkeuring.

Tot ml Jn verrassing bleek leeftijd niet van invloed te $\mathrm{zlJn}$ op de kans op afkeuring of zorgen. De verwachting was dat, aangezlen jongeren in veel hogere mate nadelige gevolgen van drankgebrulk ondervinden, bij ouderen de kans op zorgen of afkeuring groter zou zijn. Klaarbl1jkel1jk is er op dit punt 
een (voor mlj onverwacht) grote konsensus waardoor nadellge gevolgen van drankgebrulk, ongeacht de leeft1jd van degeen die ze ondervindt, zorgen of afkeuring oproepen.

Soclale klasse is bly vrouwen in Limburg van invloed op zorgen en afkeurling van famille: in de hogere soclale klasse een grotere kans op zorgen en afkeuring. Deze hogere kans kan nlet worden toegeschreven aan verschillen in de mate wartn nadelige gevolgen in de onderschelden sociale klassen voorkomen. Als nieuwe hypothese is geformuleerd dat de, vergeleken met Rotterdam, in Limburg in de hogere klasse nog onvoltoold te achten emanclpatle wat betreft drankgebrulk, de kans op zorgen over en afkeuring door famllie van het arankgebrulk verhoogt.

Urbanisatlegraad en dagonderwl Is volgen.

Twee faktoren, urbanlsatlegraad en dagonderw1 fs volgen komen in het schema alleen voor bif intensivering van drankgebrulk. Deze faktoren zal ik eerst bespreken on daama vervolgens de faktoren strukturering van het dagel1 Jks bestaan en duur huldig drankgebrulk te bespreken.

De Invloed van urbanisatlegraad op konsumptienivo kon alleen in Limburg worden nagegaan. De oorspronkel1 Jke hypothese was dat in grotere steden de sociale kontrole geringer zou zi.jn en dat dit de mogelijkheden tot onopgemerkte intensivering van drankgebrulk zou vergroten. Blj de formulertng van de hypothese werd er al op gewezen dat voorbif werd gegaan aan de mogel1jkheld dat de in klelnere gemeenten sterker te achten soclale kontrole er Juist toe bljdraagt dat er relatief veel gedronken wordt. Immers, er kumner nomen zljn die Julst het drankgebrulk stimuleren, bv. rondjes geven, café-bezoek in het weekend, en in kleinere gemeenten kan het moel11jker zljn zlch aan deze nomen te onttrekken.

De resultaten tonen aan dat in de oorspronkel1 Jke hypothese ten onrechte ervan ultgegaan werd, dat een sterkere soclale kontrole leldt tot een geringere konsumptie. Jongere mamnen uit klelne en middelgrote gemeenten (minder dan $30.000 \mathrm{in}$ woners), drinken meer dan jongere mannen uft steden (meer dan 30.000 inwoners). Waarschijnlijk is in kleine en middelgrote gemeenten de nadruk op drankgebrutk als stijlelement in de statusrol van fong volwassen man groter dan in steden. Wellicht is deze grotere nadruk op drankgebrulk ten dele het gevolg van een in klelne en middelgrote gemeenten beperkter aambod aan mogelijkheden voor vrijetijdsbesteding. 
Mannen die dagonderwl js volgen drinken, vergeleken met werkenden, minder. $B I j$ vrouwen $\mathrm{zI}$ jn er geen verschilien in konsumptie tussen degenen die dagonderwi.js volgen en degenen die werken. Dat mannen jonger dan 30 jaar, die dagonderwl js volgen, minder drinken dan werkende mannen ult dezelfde leeftijdskategorie, is in Limburg waarschijnlijk het gevolg van de geringere financlële middelen bij degenen die dagonderwijs volgen, in Rotterdam het gevolg van de gemiddeld jongere leeft1jd.

Structurering van het dagelijks bestaan.

Aan de Invloed van strukturering van het dagel1jks bestaan op intensivering van drankgebruik, nadelige gevolgen en zorgen of afkeuring, is in de voorgaande hoofdstukken relatief veel aandacht gegeven.

De variabele strukturering van het dagelijks bestaan is geIndiceerd door het hebben van arbeidsverplichtingen buiten het gezin, het samenleven met een partner en de zorg voor thuiswonende kinderen. Naar gelang een respondent aan éen of meer van deze krlteria voldeed werd een hogere skore toegekend 1.c. een meer gestruktureerd dagelljks leven toegeschreven.

Strukturering van het dagelifks bestaan en intensivering van drankgebruik.

Met betrekkIng tot intensivering van drankgebrulk werd verwacht, dat $b 1 j$ een weinig gestruktureerd dagel1.jks leven, zowel de gelegenheld als de behoefte on situatierollen waarIn drank wordt gebrulkt te Intensiveren groter 1s. Op deze manier zou gepoogd worden om, zif het gebrekk1ger dan positierolverplichtingen dat doen, alsnog struktuur en betekenls aan het alledaags leven te geven.

Deze hypothese kan voor mannen volledig bevestigd worden geacht:

bij een welnig gestruktureerd dagelljks leven komt het veel drinken vaker voor dan bif een meer gestruktureerd dagelifks leven. 
Voor vrouwen werd slechts 1 keer bif een nadere analyse naar gezinssltuatle het verwachte verband gevonden: in Limburg bleek b1y gehuwde vrouwen met bultenshuls wonende kinderen het veel drinken vaker voor te komen dan bif gehuwde vrouwen die nog wel de zorg voor thulswonende kdnderen hadden.

Dat er tusisen statusgroeperingen die verschillen in drinkpatroon -In dit geval mannen en vrouwen- verschillen kunnen zifn in de faktoren die intensivering van drankgebrulk beinvloeden, dan wel in de mate waarin deze faktoren invloed ultoefenen, werd in het theoretles hoofdstuk al gezegd. Immers, naargelang drinkpatroon kumen statusgroeperingen verschilien in de mate waarin, onder overeenkomstige omstandigheden, Intensivering van sltuatierollen waarin drank wordt gebmulkt als adekwate en voor de hand 11 ggende reaktle wordt geperclpleerd. Gezlen de Intensivering van drankgebrulk blj vrouwen in Limburg met bultenshuis wonende kinderen, is een Invloed van stmukturering van het dagel1jks bestaan op intensivering van drankgebruik van vrouwen niet volledig uit te slulten. Derhalve is in een nleuwe hypothese de verwachting vastgelegd dat, voorzover bif vrouwen incidenteel matig drankgebrulk domineert, slechts welnig faktoren lelden tot intensivering drankgebmuik.

Met betrekking tot integratie van drankgebrulk dan wel arbeldsethos, z1 fn ook nleuwe hypothesen geformuleerd. De aanlelding voor de nieuwe hypothesen aangaande de invloed van integratie van drankgebrulk of arbeidsethos, was de bevinding dat bII mamien in Rotterdam strukturering van het dagel1jks bestaan veel sterker van invloed is op intensivering van drankgebrulk dan b1j mannen in Limburg. U1t nadere analyse bleek dat de verschilien zich met name voordeden bif het ontbreken van een arbeldsrol. In Limburg was er ultslu1tend bil werkzoekende mannen sprake van een, vergeleken met werkende mannen, Intenslef drankgebrulk. In Rotterdam blj werkzoekende, arbeldsongeschikte en gepens1oneerde mannen. Men kan ervan uitgaan dat het in Rotterdam, vergeleken met het katholleke Limburg, sterker te achten (gesekwlariseerde) kalvinisties arbeldsethos, ertoe leldt dat het ontbreken van werk als een sterkere aanslag op de mogelifkheden voor een betekenlsvol bestaan wordt ervaren. DIt zou ook tot ultdrukking komen in een in Rotterdam sterkere tendens on doormiddel van situatierollen waarin drank wordt gebruikt alsnog enlge struktuur aan het alledaags leven te geven en mogel1 jk ook de spanningen van een arbeldsloos bestaan te neutral1seren. 
Het was echter nilet mogel1 jk an voor alle verschillende gezinssituaties waarin de partner ontbreekt (1.c. noolt gehuwden, gescheidenen en wedumnaars) na te gaan of er sprake was van een, vergeleken met gehuwden met Inwonende kInderen, intensief drankgebrulk. Derhalve kan niet ultgesloten worden geacht dat een andere faktor, namelijk integratie van drankgebruik, van invloed is op de mate wararin blj een weinig gestruktureerd dagelljks leven het drankgebrulk geIntensiveerd wordt. De redenering hlerbif is als volgt. Gegeven de in Limburg sterker te achten integratie van drankgebulk, is het mogel1jk dat, ook b1j een weinlg gestruktureerd dagel1jks leven, situatierollen waarin drank wordt gebrulkt in mindere mate het karakter krijgen van een 'middel' om het dagelljks leven struktuur en betekenls te geven.

Laatst genoemde mogellfkheld werpt een nleuw licht op een reeds lang gevoerde diskussle over de invloed van Integratie van drankgebrulk op de mate waarin drankgebrulk leidt tot nadelige gevolgen. Met name door soclologen is het standpunt verdedigd dat bij een beter geintegreerd drankgebrulk, alkoholkonsumptle in mindere mate tot nadelige gevolgen zou lelden. Inniddels is dit standpunt niet goed meer te verdedigen, ondat gebleken is dat het gemiddeld konsumptienivo in een bevolking de belangrijkste determinant is van de mate waarin drankgebmulk gepaard gaat met nadelige gevolgen. De hier gepresenteerde resultaten doen echter vermoeden dat voor een relatief kleine kategorle binnen de bevolking -die met een weinlg gestmuktureerd dagelijks bestaan- integratie van drankgebrulk wel van invloed is op de tendens drankgebrulk te intensiveren en (hetgeen later besproken zal worden) op de mate warin b1j overeenkomstig konsumptien1vo, drankgebruik leldt tot nadelige gevolgen.

Ten slotte wll $1 \mathrm{k}$ er nog op WlJzen dat de altematleve hypothesen ter verklaring van het versch11 tussen Limburg en Rotterdam elkaar nlet hoeven ult te sluiten. Het is voorstelbaar dat in populaties war het kalvinisties arbeldsethos relatief sterk 1s, individuen met een welnig gestmuktureerd dagelijks leven sterker genelgd zijn an drankgebruik, los van de soclale kontekst, als middel te zien om struktuur en betekenls van het dagel1jks leven te geven. Sterker in leder geval dan in populatles waar geen kulturele waarden domineren die integratle van drankgebrulk in de leefwlyze in de weg staan.

Het toetsen van de in deze laatste gedachtengang besloten 
hypothese, zou overlgens grootschalig en b1f voorkeur internatlonaal vergelifkend onderzoek verelsen.

Ik heb de vrijheld genomen on vrif ultvoerig in te gaan op de Invloed van kalvinlstles arbeldsethos en/of integratie van drankgebrulk. Voor $\mathrm{ml}$ behoren namel1 $\mathrm{Jk}$ de verschilien tussen Limburg en Rotterdam (Inklusief de nog te bespreken verschillen b1j nadellge gevolgen) tot de onverwachte en verrassende ultkomsten. Als een andere belangrijke en verrassende ultkomst beschouw $1 \mathrm{k}$ het felt dat een welnig gestmuktureerd dagel1 $\mathrm{Jks}$ bestaan zowel leldt tot intensivering van drankgebmulk alsook tot mintmallsering van drankgebrulk. Vanult een analyse-technles oogpunt beschouwd, betekent dit, dat multlvarlatechnleken die linealritelt veronderstellen -en die worden het meest gebrulkt bif gedragswetenschappe$11 \mathrm{Jk}$ onderzoek naar alcoholgebmulk- niet adekwaat geacht kurnen worden an relevante verschillen in konsumptienlvo op te sporen. Vanult theoretles oogpunt betekent het, dat er b1 I mensen met een welnig gestmuktureerd dagel1 jks leven nog nader aan te geven faktoren werkzaam z1 fn, dle mede bepalen of het drankgebruik geIntensiveerd dan wel geminimaliseerd wordt.

Strukturer1ng van het dagell Jks bestaan en nadellge gevolgen.

In het theoreties hoofdstuk werden de volgende redenen gegeven voor de verwachting dat b1f een weinls gestruktureerd dagel1 jks leven drankgebmulk, ook na kontrole op konsumptlenivo, in sterkere mate gepaard gaat met nadelige gevolgen:

- blJ een welnig gestruktureerd dagelifks leven kamt moge$11 . j \mathrm{k}$ vaker incldenteel omnatig drankgebmulk voor dat wel tot melding van nadellge gevolgen als black-outs en ongelukken leldt, echter niet tot ultdrukldng komt in opgaven van de respondent over het aantal glazen dat hi.j drlnkt,

- b1J een welnis gestruktureerd dagelljks leven worden mogelljk de effekten van drankgebrulk nadrukkel1jker gereglstreerd, hetgeen tot een hogere melding van nadelige gevolgen leldt,

- voorzover een welnig gestruktureerd dage11Jks leven wordt ondervonden als een bron van spanningen, kan dit lelden tot een verhoogde gevoellgheld voor de effekten van drank. 
De hypothese aangaande de Invloed van stmukturering van het dagelljks bestaan op nadelige gevolgen kan wat betreft mannen zonder meer bevestigd worden. Voor vrouwen is dit verband ook aanwezig, zij het dat de samenhang zwakker is dan bif mannen.

Eén aspekt van de verhoogde kwetsbaarheid voor nadelige gevolgen b1 $\mathrm{f}$ een weinig gestruktureerd dagelljks bestaan, is mogelijk gelegen in het gekombineerd gebrulk van slaap- of kalmerende middelen en alkoholhoudende drank. Het bleek namelifk, dat bif drinkers met een weinig gestruktureerd dagelljks bestaan, een hoger percentage dagelijks slaap- of kalmerende middelen gebrutkt dan bif drinkers met een meer gestruktureerd dagel1jks bestaan.

Ook blj de analyse van de invloed van strukturering van het dagelljks bestaan op nadelige gevolgen, zijn geslacht en integratle van drankgebruik als interveniërende variabelen Ingevoerd.

Wat betreft de invloed van geslacht, werd in een nleuwe hypothese het vermoeden vastgelegd, dat de bif vrouwen hoger te achten sociale druk on overnatig drankgebrulk te vermilden, leldt tot geringere verschillen in kwetsbaarheld voor nadelige gevolgen naar gelang strukturering van het dagelijks bestaan.

B1j mannen in Rotterdam $z 1 j n$ er grotere verschillen in nadelige gevolgen naar gelang strukturering van het dagelljks bestaan dan bif mannen in Limburg. Integratie van drankgebruik werd ter verklaring van dit verschil tussen Limburg en Rotterdam aangevoerd. Het bestaan van goed omschreven, met statusgenoten gedeelde drinkgewoonten, kan ertoe b1 jaragen dat, $\infty$ k voor mensen met een weln1g gestruktureerd dagelijks leven, nlet het effekt van alkohol, maar de soclale kontekst waarin wordt gedronken, sterk benadrukt blifft. Tevens is het mogelljk dat bif een beter geIntegreerd drankgebrulk minder vaak incldenteel onmatig drankgebrulk voorkomt.

Stmukturering van het dagel1jks bestaan en zorgen of afkeuring.

Strukturering van het dagelijks bestaan werd ook van Invloed geacht op zorgen, afkeuring door famllie of afkeuring door vrienden.

Het werd namelijk waarschijnlijk geacht dat bij weinig dagelijkse verplichtingen, nadelige gevolgen van drankgebrulk 
sterker opvallen als een ongewenst aspekt van de huldige leefwljze, dan in het geval dat drankgebruik niet of niet duldelljk, ultvoering van positierolverplichtingen in de weg staat.

De Invloed van strukturering van het dagelijks leven op zorgen en afkeuring door familie en vrlenden 1s, bij kontrole op de mate waar in nadel Ige gevolgen van dranikgebrulk worden ondervonden, slgniflkant.

Toch 18 de Invloed van strukturering van het dagel1jks bestaan op afkeuring door famille niet in het schema opgenomen, omdat deze invloed bif mannen in Limburg anders is dan bif mannen in Rotterdam. $B 1 \mathrm{~J}$ mannen in Limburg bleek een verhoogde kans op afkeurlng door famllie blj een weinig gestruktureerd dagelijks leven, in Rotterdam daarentegen een lagere kans. B1 v vrouwen werden er geen signiflkante verschlllen gevonden. Voor de bly mannen in IImburg en Rotterdam tegengestelde Invloed van strukturering van het dage11 ks bestaan op afkeurlng door famllie, heb lk geen verklaring. On die reden zijn deze samenhangen niet in het schema opgenomen.

Tegengesteld aan de hypothese was ook de uitkomst b1 $\mathrm{j}$ mannen In Limburg en vrouwen in Rotterdam dat bif een weinig gestmuktureerd dagel1jks leven de kans op zorgen kleiner is. Voor deze ultkomst is een, naar $\mathrm{ml}$ in mening plausibele, nleuwe hypothese geformuleerd: Indlen meer mensen afhanke11.jk zijn van een adekwate ultvoerting van positierolverpllchtingen- 1. c. bij een meer gestmuktureerd dagel1jks leven- is er een hogere kans dat nadelige gevolgen van drankgebrulk gepaard gaan met zorgen over het drankgebrulk. Ten aanzlen van afkeuring door vrlenden werd voor mannen in Rotterdam de verwachte samenhang gevonden: een hogere kans op afkeurlng door vrlenden blj een minder gestmuktureend dagell jks leven. Voor vrouwen konden geen analyses met betrekking tot afkeurlng, door vrlenden worden ultgevoerd omdat de aantallen te klein waren.

\section{Duur van huldig drankgebrulk.}

Gewenning of 'verworven tolerantie', gelndiceerd door" duur van huldis drankgebrulk, werd geacht de kans op nadelige gevolgen te verminderen, met name de kans op direkt met excesslef drankgebrulk gerelateerde verstorlngen van het 11 chame11jk funkt1oneren zoals dronkenschap, black-outs, e.d. 
Slechts voor mannen in Rotterdan werd gevonden dat bif langere duur van huldig drankgebrulk de kans op problemen met de gezondheld/ongelukken en symptomen afneemt. $B 1 \mathrm{~J}$ mannen in LImburg en Rotterdam en vrouwen in Limburg werd wel gevonden dat b1j langere duur de psychologlese afhankel1jkheld van drankgebrulk afneent. Deze bevinding staat minstens op gespannen voet met de opvatting dat bij langere duur van excesslef drankgebmulk zowel de lichamel1jke alsook de psychologlese afhankel1jkheld van drankgebrulk toeneent. Ter verklaring is aangevoerd dat bif langere duur van drankgebruik well1cht het besef toeneemt dat alkoholgebrulk niet helpt on bv. het zelfvertrouwen te vergroten, verdrlet te verwerken. Daarmee is niet gezegd dat het onmogelifk is dat bij langere duur van excessief drankgebrulk de afhankel1jkheld van drank on met onopgeloste problemen verder te leven toeneemt. Wél dat de manler warop in deze en andere studies psychologiese afthankel1jkheld wordt gelndlceerd, namel1jk als "oplossing" voor problemen, waarschijnli $\| k$ niet adekwaat is an de afthankel1jkheld van drank om met onopgeloste problemen verder te leven te meten.

B1j langere duur van ovematig drankgebrulk werd ook verwacht dat de kans op zorgen en afkeuring door famille of vrienden zou toenemen. Slechts voor vrouwen in Rotterdam kan deze hypothese bevestigd worden geacht.

Voor mamnen in LImburg en Rotterdam is, tegengesteld aan de hypothese, bif langere duur van huldig drankgebrulk de kans op zorgen (Rotterdam) afkeuring door famllie (Rotterdam en Limburg) en afkeurlng door vrlenden (Rotterdarn) klelner. Het uitgangspunt voor de corspronkel1.jke hypothese, namel1.jk dat bif langere duur van drankgebrulk gepaard gaand met nadelige gevolgen, bij de drinker zelf en zijn angeving het besef toeneent dat het on onwenselijk of onaanvaardbaar drankgebruik gaat, blijkt wat betreft mannen nalef te z1.jn. Gegeven het onbreken van gedeelde nomen aangaande drinkgedrag, is er geen sprake van een regelmatlge toename van zorgen of kritlek bij langere duur van overmatig drankgebrulk. Er is wat betreft vrienden waarschijnl1.jk sprake van een selektleproces waarblj de drlnker de kans op afkeuring minimaliseert, wat betreft familie van berusting indien kritlek niet de gewenste verandering van drinkgedrag tot gevolg heeft. B1f de drinker zelf is er warschijnl1jk sprake van onderschatting van de risiko's van zijn huldig drankgebrulk. 


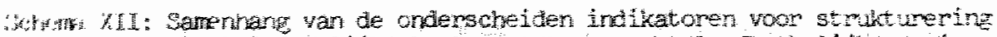

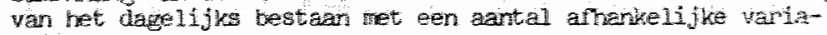
beven

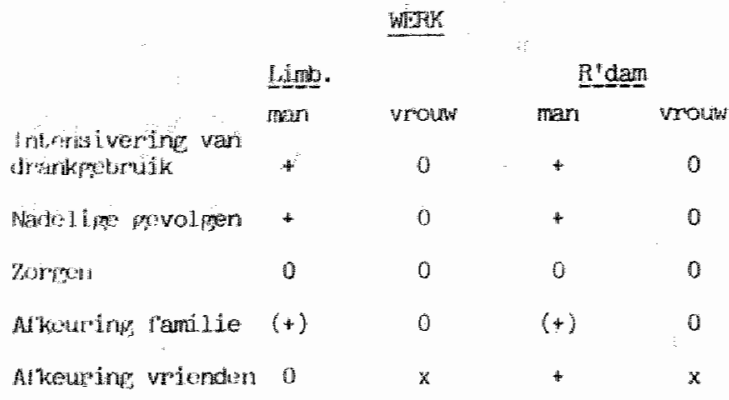

\section{PATINIR}

\begin{tabular}{|c|c|c|c|c|}
\hline \multirow[b]{3}{*}{$\begin{array}{l}\text { Int ansivering van } \\
\text { drankgebruik }\end{array}$} & \multicolumn{2}{|l|}{ Limbil. } & \multicolumn{2}{|c|}{$\mathrm{A}^{\prime} \mathrm{dam}$} \\
\hline & man & VTOLW & $\operatorname{man}$ & vrouw \\
\hline & + & 0 & + & 0 \\
\hline Nade llige gevolgen & + & * & + & + \\
\hline Zorgen & + & 0 & 0 & $(+)$ \\
\hline Afkeuring familie & + & 0 & + & 0 \\
\hline \multirow[t]{4}{*}{ Arkeuring ynienden } & 0 & $x$ & $(+)$ & $x$ \\
\hline & 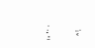 & \multicolumn{3}{|c|}{ MUISWOMENDE KTNDEPEN } \\
\hline & Lignb. & & \multicolumn{2}{|c|}{ n!dam } \\
\hline & & Wrotw & man & vroum \\
\hline 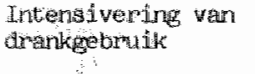 & + & $*$ & 0 & 0 \\
\hline Made 1.jge walgen & $(+)$ & $\therefore \quad 0$ & $(+)$ & 0 \\
\hline $70 \mathrm{mgen}$ & 0 & 0 & 0 & * \\
\hline Artcetwing famil ile & 0 & 0 & 0 & 0 \\
\hline Afkeuring wienden & 0 & $x$ & 0 & $x$ \\
\hline
\end{tabular}

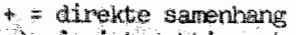

( ) in interalkie net andere indikatoren

$x=$ niet genalyseard:

0 F gen wersehi
} 
Als nleuwe hypothese is dan ook geformuleerd dat bif langere duur van huldig drankgebruik de kans op zorgen, afkeuring door familie of vrienden bif mannen afneemt.

XI. 2. Indikatoren voor strukturering van het dagel1jks be-

Bif alle analyses warin de variabele stmukturering van het dagelljks bestaan is ingevoerd, zijn nadere analyses gedaan om na te gaan of de onderscheiden indikatoren voor strukturering van het dagelifks bestaan ook afzonderlijk van invloed zijn.

In schema XI is aangegeven voor welke Indikatoren één direkte dan wel indirekte (namelijk in interaktie met één of beide andere indikatoren) slgniflkante samenhang is gevonden.

Voor geen van de indikatoren kan gezegd worden dat er in geen enkel geval een signifikante samenhang werd gevonden. Wel is er een duldelljk verschil tussen mannen en vrouwen in het aantal samenhangen en, b1j mannen, in het aantal samenhangen voor de afzonderl1jke indikatoren.

op het verschil tussen mannen en vrouwen is in het voorgaande reeds Ingegaan. Aan de hand van het schema kan één van de oorzaken aangegeven worden waarom voor vrouwen minder vaak of minder sterke samenhangen werden gevonden. Het ontbreken van werk blijkt bij vrouwen namelljk geen enkele keer van Invloed te zljn. Hieraan moet wel toegevoegd worden dat veel minder vrouwen dan mannen als voornaamste kermerk van hun werksituatle opgaven dat ze werkzoekend, arbeidsongeschikt of gepensioneerd waren. De kans op een signifikante samenhang tussen het ontbreken van werk en één van de afhanke11 jke varlabelen moet voor vrouwen dan ook lager geacht worden dan voor mannen. Fchter mogelljk is het ontbreken van arbeldsverplichtingen buttenshuis bif vrouwen in mindere mate van invloed op de strukturering van het dagelljks leven. Voor het ontbreken van een partner en zorg voor thulswonende kinderen wordt bij vrouwen wel een aantal keren een signif1kante samenhang met de afhankelifke variabelen gevonden.

In tegenstelling tot de uitkonsten bif vrouwen wordt bif mannen in Limburg en Rotterdam bifna even vaak voor werk (namelijk zeven keer) als voor het ontbreken van een partner (acht keer) een samenhang gevonden met één van de afhanke- 
11jke varlabelen. De konklusie is dat werk en het ontbreken van een partner bij mannen de belangrljkste indikatoren zijn voor een welnfg gestruktureerd dagelifks leven. De drle keer dat er een samenhang wordt gevonden van zorg voor thuiswonende kinderen met de afhankelljke variabelen, duidt erop, dat dit een minder belangrifk aspekt is van de stmukturering van het dagel1jks leven van mannen.

XI. 3. Dorzakel1jkheld en geldigheld van de gevonden samenhangen.

Oorzakel1 jkhe1d

De vraag naar de corzakel1jkheld van de gevonden samenhangen geldt het sterkst voor de invloed van twee indikatoren voor een weinig gestruktureerd dagelijks leven -het ontbreken van een partner of werk- op intensivering van drankgebruik. Met betrekking tot de andere in het schema genoemde faktoren, bv. de Invloed van statusfaktoren op drinkpatronen, nadelige gevolgen of de Invloed van urbanisatiegraad op intensivering van drankgebrulk, moet het hoogst onwaarsch1jnlijk worden geacht dat de richting van de samenhang anders is dan nu wordt aangegeven.

De gegevens waarover $1 k$ beschjk wljzen er niet op dat drankgebrulk in hoge mate tot verlies van werk leidt. In Limburg en Rotterdam antwoordden in totaal respektievelijk 4 en 10 respondenten dat ze zijn opgehouden met werk vanwege drankgebrulk. Mif l1jkt het zeer onwaarschljnl1jk dat deze aantallen respondenten verantwoordelifk zl.jn voor de gevonden samenhang tussen het ontbreken van werk en intensivering van drankgebru1k. Voor Rotterdam kan daar nog aan toegevoegd worden dat $\infty \mathrm{k}$ voor gepensioneerden vastgesteld werd dat deze, vergeleken met werkenden, Intensief drinken. BIj gepensioneerden is het zeer onaamemel1jk dat het ontbreken van werk veroorzaakt is door overmatig drankgebrutk. Betreffende het ontbreken van een partner, beschlk $1 \mathrm{k}$ alleen over het aanvullende gegeven of de partner van de respondent gedrelgd heeft weg te gaan of echt is weggegaan. In LImburg en Rotterdam beaamden respektievelijk 8 en 10 respondenten dit Item. Voor gescheldenen konden echter geen aparte analyses ultgevoerd worden wat betreft intensivering van drankgebruik, zodat hler geen konklusies mogelljk zljn. 
Voor de noolt gehuwde mannen ouder dan 30 jaar in I Imburg en Rotterdam, werd ook vastgesteld dat deze een vergel1,jkenderwl Is intensief drankgebmuik kennen. Voor deze kategorle is het voorstelbaar dat in meer of minder gevallen de gehechtheld aan intenslef drankgebrulk het aangaan van duurzame relaties in de weg heeft gestaan. Voor oudere noolt gehuwde mannen in Limburg en Rotterdam bestaat derhalve de grootste onzekerheld of het noolt gehuwd zifn gevolg is van drankgebrulk dan wel de oorzaak is van een vergelljkenderwljs intensief drankgebruik.

Geldigheid

De geldigheld van de gevonden samenhangen, gezlen in het l1cht van de grote onderschatting van alkoholkonsumptie en waarschifnlifk ook van de nadelige gevolgen van drankgebrulk en zorgen en afkeuring, blifft een probleem in survey-onderzoek.

Men kan het mijns Inzlens extreme standpunt Innemen dat, gegeven deze onderschatting, geldige konklusies vrljwel onmogelijk geacht moeten worden.

Een redelijker werkwljze is mifns inzlens on ten eerste de populatie waarover men ultspraken pretendeert te doen, nauwkeurig te onschrijven. B1j alkoholonderzoek met survey-gegevens moet men er volgens mij vanuit gaan, dat de konklusles slechts geldig zijn voor dat deel van de bevolking dat met standaard veldwerk methoden geinterviewd kan worden. Met deze beperking is de mogelijkheld van selektleve non-respons, waar zlch mogelljkerwljs andere samenhangen voordoen dan bif de populatie die toegankelijk is met standaard veldwerk methoden, onderkend. Maar ook wordt erkend dat dit, onderzoeksmatig gezlen, een apart probleem is, dat met andere onderzoeksmethoden opgelost moet worden.

Gegeven deze welbewuste beperking van konklusies tot de populatie die met standaard veldwerkmethoden berelkbaar is, wordt het probleem van de geldigheld van gevonden samenhangen teruggebracht tot het probleem van mogel1jke systematiese verschillen tussen soclale kategorieën in onderraportage van konsumptle, nadelige gevolgen en zorgen of afkeuring van drankgebrulk.

Ten aanzlen van het probleem van systematiese verschillen in onderrapportage, kan naar inijn mening in redel1 jkheld worden volgehouden dat, voorzover onderzoek naar onderrapportage 
geen aanwljzlngen oplevert voor systematles verschlllen, ën de gevonden samenhangen op theoretiese gronden aamnemel1 jk gemaakt kunnen worden, de geldigheld van de gevonden samenhangen voorhands niet betwljfeld hoeft te worden.

Het schaarse onderzoek naar onderschatting heeft tot nu toe voor de in het schema genoemde faktoren alleen opgeleverd dat vrouwen well1cht hum alkoholkonsumptie sterker onderrapporteren dan mannen en waarsch 1 Jnl1 jk vaker verzw1jgen dat ze krltlek uit de omgeving hebben gekregen. Deze mogel1 jke verschillen in onderrapportage tussen mannen en vrouwen $\mathrm{z} f \mathrm{fn}$ een belangrljke reden geweest om de analyses zoveel mogeljk apart voor mannen en vrouwen ult te voeren. BIJ twee probleemstellingen is de faktor geslacht als een onafhankelijke varlabele opgevoerd, namel1 jk b1f drinkpatronen en b1f nadelige gevolgen. B1J zorgen en afkeuring is geslacht welbewust niet als corzakelijke faktor in het schema opgenomen, ondanks de slgnifikante invloed ervan, julst omdat de b1f vrouwen waarsch1jnl1 jk hogere onderrapportage van kr1tiek, grote twijfels toelaat aan de geldigheld van de uitkomst. BIJ de invloed van geslacht op drinkpatroon, 11jkt het me hoogst onwaarschljnl1 jk dat systematiese verschillen tussen mannen en vrouwen in onderrapportage, ertoe geleld hebben dat aan vrouwen veel vaker dan mannen een verkeerd drinkpatroon wordt toegeschreven.

BIJ de invloed van geslacht op nadelige gevolgen van drankgebrulk, kan inderdaad getwljfeld worden aan de geldigheld van de gevonden samenhang.

In plaats van de nu voorgestelde redenering -b1f mannen kont vaker incldenteel onmatig drankgebrulk voor- is het ook voorstelbaar dat vrouwen terughoudender zifn dan mannen met het melden van nadelige gevolgen van drankgebrulk. Alleen nader, speciflek gerleht onderzoek, kan ultwljzen of de hler voorgestelde redenerling ter verklaring van de invloed van geslacht op nadelige gevolgen geldig is. Voor soclale klasse en leeftijd z1.jn in de $\mathrm{mlj}$ bekende onderschattingsonderzoeken, geen verschilien in onderrapportage gevonden. Ten aanzien van de andere in het schema genoemde faktoren, bv. urbanisatiegraad, strukturering van het dagelifks bestaan, is volgens $\mathrm{mi} f$ nog noolt nagegaan of deze samenhangen met systematiese verschilien in onderrapportage. Met ultzondering van de varlabele strukturering van het dagel1jks bestaan, kan $1 \mathrm{k}$ ook moel11jk aannemel1jke redenen 
bedenken op grond warvan systematlese verschillen in onderrapportage naar gelang urbanisatiegraad, of dur huldig drankgebruik te verwachten $21 \mathrm{jn}$. Om die reden en omdat $1 \mathrm{k}$ de theoretlese verklaring voor de betreffende samenhangen plausibel acht, ben ik niet genelgd de geldigheld van deze samenhangen te betwljfelen.

Dit is anders voor de samenhangen tussen strukturering van het dagelljks bestaan en nadelige gevolgen. In de verklaring voor deze samenhang wordt namelijk al gewezen op de mogelifkheld van systematiese verschillen in onderrapportage. Er is namel1 Jk gesteld dat de hogere kwetsbaarheld voor nadel1ge gevolgen bij een weinig gestmuktureerd dagel1jks leven mogel1.jk het gevolg is van een bij een weinig gestruktureerd dagel1Jks leven vaker voorkomend incldenteel onmatlg drankgebruik. Dat wil zeggen een sterkere onderschatting van konsumptle. Als andere mogel1jkheld is genoemd, dat b1j een welnig gestruktureerd dagelijks leven de nadelige effekten van drankgebrulk nadrukkel1Jker geregistreerd worden. Dit zou betekenen dat de onderrapportage van nadelige gevolgen minder groot is bif een weinig gestruktureerd dagelijks bestaan.

Deze mogelijke verschillen in onderrapportage naar gelang strukturering van het dagelijks bestaan, tasten echter nlet de geldigheld van de gevonden samenhangen aan, doch bleden een verklaring daarvoor.

De slotkonklusie wat betreft de geldigheld van de in de figuur aangedulde samenhangen is, dat het merendeel daarvan geldige samenhangen geacht kunnen worden.

XI. 4. Enkele beleldsoverwegingen

In voorgaande publikaties is ultgebreld ingegaan op de beleldsaanbevelingen die op grond van het Limburgse en Rotterdams onderzoek zijn te doen. (Garretsen, 1982; Knlbbe, 1982; Knibbe, Garretsen, 1983; Garretsen, 1983).

Hier zal $1 \mathrm{k}$ me beperken tot de aanbevelingen, die meer direkt in de 11.jn 11ggen van de uitkomsten van deze studie. In anderstaand schema staat nogmaals aangegeven welke groeperingen een bijzonder risiko bij éen of meer fasen in het proces van gangbaar tot problematies drankgebruik kan worden toegeschreven. Ter wlile van de soclale herkenbaarheld, zifn 
de konklusless in het schema niet geformuleerd in temen van strukturering van het dagelifks leven, maar in temen van werk- en gezinssituatie.

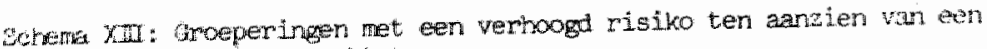
of meer aspelden.

\begin{tabular}{|c|c|c|c|c|c|}
\hline . & $\begin{array}{l}\text { Tntenstwe- } \\
\text { ring } \\
\text { drankge- } \\
\text { buik }\end{array}$ & $\begin{array}{l}\text { Kuetsbaam- } \\
\text { heid roor } \\
\text { rade } 1 \text { ige } \\
\text { gevolger }\end{array}$ & zorgen & $\begin{array}{l}\text { Afmeuring } \\
\text { fami ine }\end{array}$ & $\begin{array}{l}\text { Alweurine } \\
\text { veienden }\end{array}$ \\
\hline ges lacht: mantiner & 4 & 4 & * & * & * \\
\hline 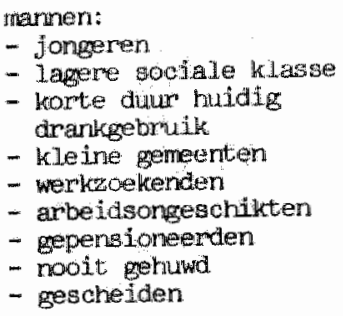 & $\begin{array}{l}0 \\
\times \\
+(L) \\
+ \\
+(R) \\
+(R) \\
+(-30 j r) \\
x(x)\end{array}$ & $\begin{array}{l}+ \\
x \\
+ \\
+ \\
+ \\
+ \\
+\end{array}$ & $\begin{array}{l}0 \\
0 \\
x \\
0 \\
0 \\
0 \\
+(L) \\
+(I)\end{array}$ & $\begin{array}{l}+ \\
x \\
* \\
0 \\
*(R) \\
*\end{array}$ & $\begin{array}{l}+ \\
x \\
+(R) \\
+(R) \\
0 \\
0 \\
+(R)\end{array}$ \\
\hline $\begin{array}{l}\text { mouwen: } \\
\text { - jongeren } \\
\text { - hogere soeiale klasse } \\
\text { - noolt gehwid } \\
\text { - gescheiden }\end{array}$ & $\begin{array}{l}0 \\
+ \\
0 \\
0\end{array}$ & $\begin{array}{l}+ \\
- \\
+ \\
+\end{array}$ & $\begin{array}{l}0 \\
+(\mathrm{L}) \\
0 \\
0\end{array}$ & $\begin{array}{l}a \\
+(L) \\
0 \\
0\end{array}$ & $\begin{array}{l}x \\
x \\
x \\
x\end{array}$ \\
\hline 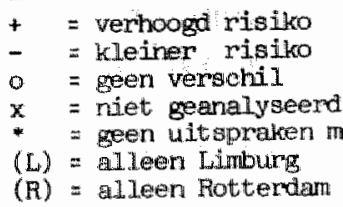 & Trge 1 ijo $k$ & & & & \\
\hline
\end{tabular}

In princlpe kunnen alle groeperingen waar een verhoogde kans op Intensivering van drankgebrulk en/of een verhoogde kans op nadelige gevolgen beschouwd worden als risikogroepen. Een verhoogde kans op zorgen of afkeuring, zou $1 \mathrm{k}$ nlet willen beschouwen als risikofaktor. Integendeel, gegeven de cruclale rol die zorgen en afkeuring van anderen spelen bij pogingen het drankgebrulk te matigen of te stoppen met drinken is een verhoogde kans op zorgen of afkeuring in dat opzlcht positief te warderen.

Ik zal niet alle in het schema genoemde groeperingen stuk voor stuk behandelen, maar me beperken tot de aanbevelingen die niet eerder gedaan zijn. 
Aan het slot van de paragraaf zullen enkele aanbevelingen voor nieuw onderzoek worden gedaan.

De eerste aanbeveling betreft de faktor strukturering van het dagelljks bestaan: gerlchte inspanningen ter voorkoming en beperkling van drankgebrulk gepaard met nadellge gevolgen dienen vooral gericht te zijn op mannen met een weinig gestruktureerd dagel1 jks leven, in het bljzonder werkzoekenden en nooit gehuwde mannen.

De basls voor deze beleldsaanbeveling is de bevinding dat strukturering van het dagelljks leven vooral bij mamen van invloed is op zowel intensivering van drankgebruik als op een verhoogde kwetsbaarhe1d voor nadellge gevolgen. Werkzoekende en noolt gehuwde mannen worden speciaal genoemd, ondat ult nadere analyses bleek, dat deze twee groepen zowel ten aanzien van intensivering van drankgebrulk als ten aanzlen van kwetsbaarheld voor nadelige gevolgen, een verhoogd rlslko lopen. Voor geschelden mannen kon ntet worden nagegaan of bij deze de kans op intensivering van drankgebrulk hoger 1s. Ik vermoed echter dat bil meer gerlcht onderzoek kan worden aangetoond dat b1j geschelden mannen de kans op Intensivering van drankgebrutk hoger is.

Wat betreft werkzoekende mannen neem $1 \mathrm{k}$ nogmaals de vrl Jheid erop te wljzen dat onderzoek, dat op grond van vergel1jking van de gemiddelde konsumptle meldt dat werkzoekenden (en ook arbeldsongeschikten) minder drinken dan werkenden, zoals recent nog in een rapport van het Soclaal Cultureel Planbureau (Becker, Vink, 1984) een verkeerd beeld geeft van de verschilien in alkoholkonsimptie tussen werkenden enerzljds en werkzoekenden of, breder, niet aktieven anderzijds.

De tweede beleldsaanbeveling betreft één aspekt van de verhoogde kwetsbaarheld voor nadelige gevolgen bid een welnig gestruktureerd dage $11 \mathrm{jks}$ leven.

Aangetoond werd dat b1f drinkers met een welnig gestruktueend dagel1jks leven, vaker dagel1jks gebruik van slaap- of kalmerende middelen voorkomt.

Derhalve de volgende beleldsaanbeveling:

B1j drinkers met een weln1g gestmuktureerd dage 11 jks leven zijn extra Inspanningen ter voorkoming van het gekombineerde gebrulk van alkoholhoudende drank en slaap- of kalmerende middelen aan te bevelen. 
De verschillen tussen Llmburg en Rotterdam zifn aanlelding voor de volgende aanbeveling:

In Limburg dient preventle van rlsikovol drankgebrulk verge11jkenderwijs minder sterk op risikogroepen en sterker op de gehele bevolking of grote delen daarvan gerlcht te $z 1$ In. In Rotterdam verdient het aanbeveling om de preventie vergel1 jkenderwljs sterk op risikogroepen te richten en minder sterk op de gehele bevolking.

De argumenten voor deze aanbeveling zifn door de gehele studie heen te vinden:

- In Limburg kunnen de Jongere mannen als geheel als risikogroep ten aanzien van intensivering van drankgebrulk worden beschouwd. In Rotterdam is er geen enkele statusgroepering die in die mate een verhoogde kans op veel drinken vertoont.

- In Rotterdam wordt vaker dan in LImburg gevonden, dat mannen zonder werk en/of zonder partner hum drankgebrulk intens Iveren. Eveneens wordt in Rotterdam vaker dan in I Imburg gevonden dat mannen zonder werk of zonder partner een verhoogde kwetsbaarheld voor nadelige gevolgen van drankgebruik ondervinden.

In Limburg is over het geheel de kans op zorgen zorgen of afkeuring kleiner dan in Rotterdam, ook als gekontroleerd wordt op de mate waarin nadelige gevolgen van drankgebrutk worden ondervonden. Dit w1.Jst erop dat in Limburg de onderschatting van de risiko's van drankgebruik sterker is dan in Rotterdam.

Ik wil er nog op wljzen dat hier aksentverschillen in beleld ten aanzien van preventle worden aanbevolen. Er wordt nlet aanbevolen dat in Rotterdam gestreefd zou moeten worden naar Integratle van drankgebruik in het leefpatroon van statusgroeperingen, of in Llmburg gestreefd zou moeten worden de bestaande integratie van drankgebrulk in het leefpatroon sterk af te zwakken.

De resultaten met betrekking tot de kans op zorgen, en afkeurling zifn aanlelding voor de volgende aanbeveling:

Het verdient aanbeveling on een volksgezondheldsbeleld te ontwikkelen gerlcht op vroegt1jalge herkerning van drankgebrulk gepaard gaand met nadelige gevolgen.

Deze beleldsaanbeveling vloelt voort uit de bevinding dat b1 I mannen de kans op afkeuring en zorgen vermindert bly langere duur van overnatig drankgebrulk. 
Natuurlijk hoop ik dat de in deze studie nleuw ontwikkelde hypothesen door verder onderzoek getoetst worden. Daarnaast wil ik nog de volgende suggesties doen ten aanzlen van nleuw onderzoek.

Verschillen tussen veel en weinig drinkers bij mannen met een weinig gestruktureerd dage11 jks leven.

Van dit onderzoek mag verwacht worden dat het faktoren aangeeft waarmee de verschillen in alkoholkonsumptie verklaard worden, en ook konkrete beleids- suggesties oplevert hoe intensivering van drankgebrulk en/of een verhoogde kwetsbaarheid bif mannen met en weinig gestruktureerd dagel1jks leven voorkomen kan worden.

De invloed van de integratie van drankgebruik op intens lvering van drankgebrulk door mannen met een weinls gestruktureerd dageli jks bestaan.

Onderzoek hiemaar zou zlch moeten richten op verheldering van de invloed van de integratie van drankgebruik of het drinkgedrag van de enkeling, de soclale kontekst waarin wordt gedronken, de betekenissen waarmee drankgebrulk is omgeven en de kans op subkulturen met, ten aanzlen van drankgebruik, afwljkende normen en gedrag.

De sociale en mediese aspekten van de karrières van langdurlge probleendrinkers.

Gezlen het belang van vroegtifdige herkenning van probleemdrinken en de belangrijke rol die de naaste ongeving speelt bij de bereidw1lligheld van probleemdrinkers an hun drinkgedrag te veranderen is gertcht onderzoek naar de faktoren die bljdragen aan late herkenning van probleemdrinken door de medlese professle en afzwakken of verstommen van de kritiek van de direkte angeving, aan te bevelen.

Prospektief onderzoek zou hier, zoals meestal, het beste zijn.

Fen minder kostbare en tijdrovende vorm van onderzoek is een retrospektleve konstmuktle van de soclale en mediese aspekten van de karrières van probleendrinkers die bekend $\mathrm{z} 1 \mathrm{y} n$ bij (bv.) algemene en psychiatriese ziekenhulzen en C. A. D. 's.

Het verdient aanbeveling bif dit onderzoek ook de famllie en (vroegere) vrienden van de probleemdrinker te betrekken alsmede artsen die de probleendrinker als patient hebben gehad. 
From everyday drinking to problematic drinking

This study deals with the following interrelated questions:

I. Which drinkting patterns are prevalent in the populations studied?

II. Which social factors are assoclated with differences in drinking patterns?

III. Which factors contribute to an Intensification of the use of alcohollc beverages?

IV. Which factors, other than consumption level, contribute to the likellhood that the use of alcohol will lead to harmful effects?

V. Which factors, other than harmful effects, contribute to the chance that drinking is disapproved by the social environment and/or the drinker worries about his drinking?

In the first four chapters hypotheses related to these problems are gemerated.

The first hypothesis states that the varlety of drinking behaviour of Individuals can be reduced to a restricted number of drinking patterns.

Drinking patterns are described as "styles" of drinking, characterized different aspects of drinking behaviour. The aspects of drinking behaviour used in this study to define drinking patterns are (1) amounts consumed on weekdays and (2) weekenddays, (3) frequency of drinking and (4) place of drinking (at home or public places).

The hypothesis about common drinking patterns might seem to be in contrast with the finding that there do not seem to be general norms regulating concrete aspects of drinking behaviour like amounts permitted to be consumed on various occasions or frequency of drinking. Two reasons are given for the expectation that, although explicit norms concerning drinking behaviour are lacking, individual drinking behaviour will in fact tend to be conform to one of several prevalent drinking patterns:

- the individual will tend to follow the example of others in his reference group in order to give a risky habit like drinking a meaningful place in his life style 
- it is of some importance that the social environment of the drinker is able to recognize that the individual drinks in a socially acceptable way. This is only possible if there is some uniformity in the social acceptable ways of drinking, viz drinking behaviour is organized in a restricted number of drinking patterns. Socially acceptable ways of drinking, should not be 1dentiflied with -from the public health perspective- responsible ways of drinking. These drinking patterns, because they are defined as socially acceptable make it legitimate to avold to a certain extent questions about harmful effects rather than prevent harmful effects.

Regarding the second problem, it was hypothesized that status groups defined in terms of one or more of the variables sex, age, social class and religion, tend to differ in drinking pattern.

Th1s hypothesis is derived from the role-theory of the German sociologist U. Gerhardt (1971). She distingulshes three types of roles which have different functions for the Individual:

- statusroles: expectations based upon soclal characteristics which the individual himself is (hardly) able to influence 1.c. social class, sex, age and religion. Status roles provide the Individual with a general orientation of how to behave in a large variety of social situations;

- position roles: expectations based upon the position a person occupies in a social network, such as a famlly or a workorganization. Position roles structure the everyday 11 fe of the individual with meaningful activities.

- situation roles: the social expectations which make 1t. possible to interact in short-term situations in which people pursue and attain specific goals. V1siting football matches or bars and driving a car are examples of situation roles.

The use of alcohollc beverages belongs in the context of s1tuation roles. However, statusroles indicate in which situations the use of alcohol is considered appropriate, in their function of giving a general orienation. Statusroles Indicate how to integrate drinking as a meaningful element of the Iife style.

Two hypotheses have been formulated concerning factors contributing to an intensification of alcohol use. 
It is expected that people with a somewhat less-structured everyday $11 \mathrm{fe}$ w111 tend to intenslfy their consumption. Those people might tend to use situation roles, including those in which alcoholic beverages are used, to give some structure and meaning to their everyday iffe. The score on the varlable degree of structure of everyday 11 fe is measured by the following number of position roles of the respondent: working outdoors, living with a partner, care for children at home.

The second hypothesis states that in small communties the consumption level will be lower than in clties (more than 30.000 inhabltants) because social control in small conmunities is more intense.

Besldes level of consumption, the following factors are expected to influence the harmful effects of drinking.

Status factors assoclated with differences in drinking pattern. A consumption of twenty glasses concentrated only on two weekkend days is more likely to lead to for example drunkenness or accidents than if the consumption of 20 glasses is evenly spread over the seven days of the week. The degree of structure of everyday 1 ife

For the following-three reasons it was hypotheslzed that people with a less structured every day life are more vulnerable to the harmful effects of drinklng:

- because of the lack of meaningful activitles they are likely to experlence more stress, posslbly making them vulnerable to the effects of alcohol;

- they might more often engage in binge drinking than people with a more structured everyday iffe.

The consumption on binges was not determined directly, although such harmful effects as for example tremors, blackouts were measured;

- the lack of meaningful activities possibly leads to a more emphasized registration of the effects of alcohol. Acquilred tolerance, (indicated by the length of time people drink the same amounts) is thought to be of influence because clinical studles show that heavy drinkers have to drink increasing amounts to experlence the same effects.

The Ilkelthood that with a similar degree of harmful effects, a person worries about his drinking or experiences disapproval, is expected to be Influenced, by an almost 
identical set of factors as mentioned before: status factors, degree of structure of everyday $11 \mathrm{fe}$ and duration of present drinking habits.

onl y as far as status groups differ in the prevalence of harmful effects of drinking (because of differences in drinking patterns) can statusfactors be thought of as influencing worrles and/or disapproval. It is thought likely that status groups with a high prevalence of harmful effects, w1ll tend to be more reluctant to worry about one's own or to criticize the other's drinking.

It is expected that in the case of a less-structured everyday life, the drinker and/or his social environment experience harmful effects of drinking as a more outstanding feature of the present Iffy style than if (In spite of hamful effects) a person st1ll fulfills concrete soclal obligations.

The duration of present drinking is expected to influence worrles and/or disapproval because it is thought to be $11 \mathrm{kely}$ that the longer one drinks to excess, the more difflcult it becomes to avoid criticlsm or worries.

To test these hypotheses data from two ident1cal surveys conducted in the province of Limburg and the city of Rotterdam respectively are used. In two aspects there are rather large differences between these two reglo's. In

Limburg $90 \%$ of the respondents professes to belong to the Roman Catholic church. In Rotterdam 56\% of the respondents says they have no religlous denomination (however, probably raised by parents of Protestant background); $27 \%$ of the respondents says they are Protestant. A further difference is that Rotterdam is the blggest clty in the Netherlands while in Limburg mainly small communties are found.

In al1 analyses concerning factors influencing harmful effects, level of consumption was statistlcally controlied for. In all analyses concerning disapproval of or worrles about drinking, the degree of harmful effects was controlled for.

Except for the analyses concerning the influences of sex, all analyses have been carried out seperately for men and women in Limburg and Rotterdam. 
Results

The results are presented in the figure underneath.

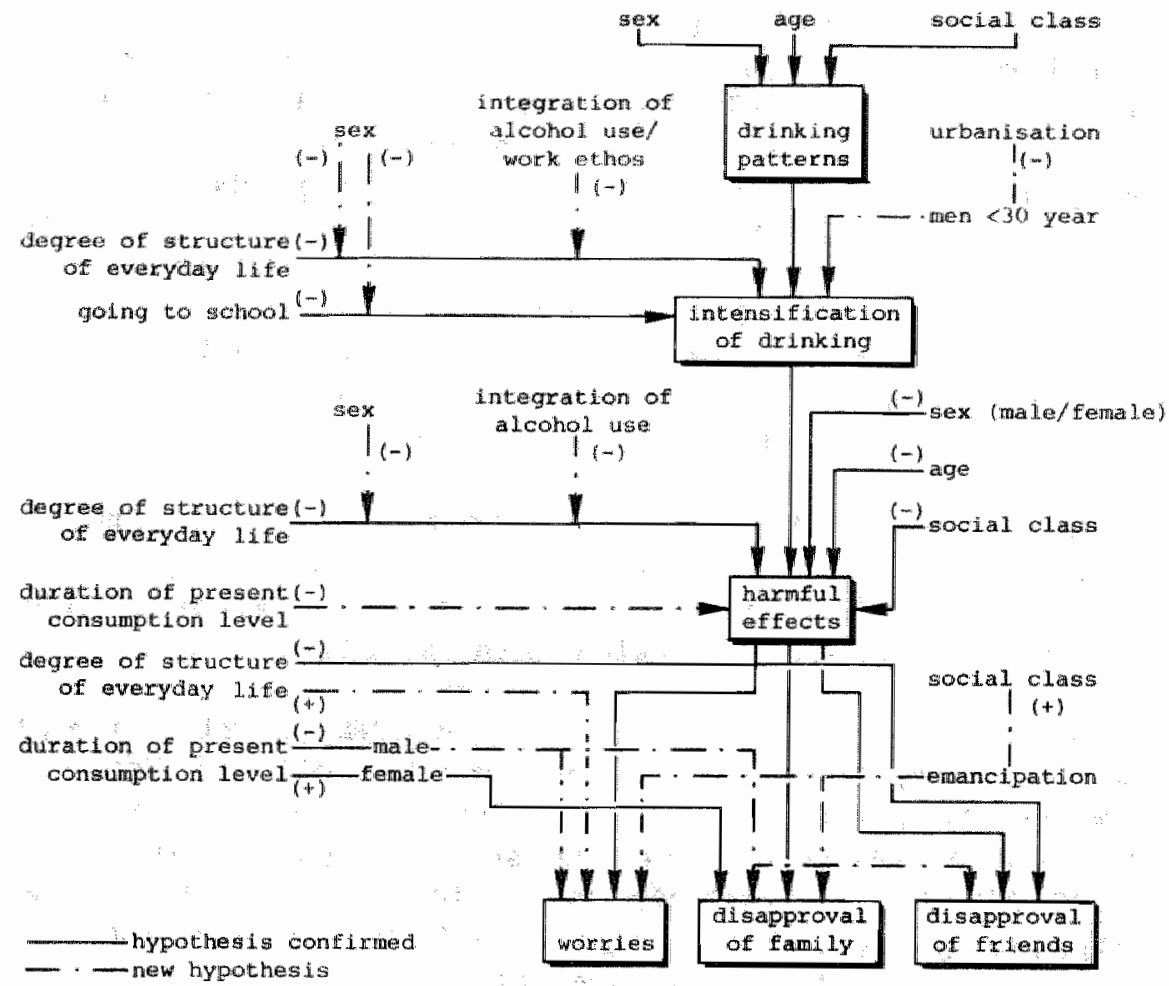

Firstly the Influence of status factors and duration of present consumption on the set of dependent variables w111 be discussed. Following this the influence of degree of structure of everyday IIfe, going to school and urbanisation w111 be discussed.

The hypotheses concerning the existence of drinking patterns and differences in drinking pattem between status groups were confl 1 med.

In LImburg and Rotterdam, the drinking behaviour of the large marjority agrees with one of the three prevalent arinking patterns in these areas. Two drinking patterns are the same in Rotterdam and Limburg: 'Incidental moderate use' (average frequency of 3 times a month and average consump- 
tion per drinking occasion of about 1 glass) and 'dally drinking at home'. Another drinking pattern, called "perlodic drinking" was only found in Limburg. The main characteristic of this drinking pattern is that the consumption on two weekenddays greatly exceeds the consumption on the preceeding five weekdays. In Rotterdam a third drinking pattern, called 'mixed style of drinking' was found. The "mixed style of drinking" is characterized by a higher number of drinking days than incidental moderate use and a lower number of drinking days than dally drinking at home. Incldental moderate use is the dominant drinking style of women in Limburg and Rotterdam. Dally drinking at home occurs more frequently in the older age groups, especially those of the higher soclal class. Periodic drinking in Limburg and the mixed style of drinking in Rotterdam is found more often in the younger age groups.

Compared with the mixed style of drinking, the drinking pattern of periodic drinking in Limburg contains clearer Indications of how to drink. This fact and the fact that the differences in drinking pattern between status groups in Limburg are stronger than in Rotterdam, led to the conclusion that drinking in Limburg is a more cleary defined and integrated element of the status role.

Harmful effects are measured by the score on an index in which psychological dependence (or escape drinking), symptoms, problems with health/accidents and frequency of drunkenness/hangover are comblned. Status groups with a restricted frequency of drinking -the younger and the lower social classes- experience more harmful effects at similar amounts of consumption. At a similar level of consumption men report more harmful effects than women, posslbly because the consumption on binges is not systematically asked for, whereas harmful effects 11 ke drunkenness or black-outs are; and/or because women tend to stronger underreporting of adverse consequences of drinking.

The younger were also expected to experlence less worrles or disapproval than the older. This hypothesis was not confirmed: there were no differences. Soclal class, for which no differences were expected, appeared to be of influence. In Limburg women of the higher soclal classes more often worry or experience disapproval from family than middle or lower class women. 
Further analysis showed that, compared wlth Rotterdam, wonen of the higher soclal classes in Limburg are less emancipated concerning the use of alcohol. A process of emancipation which has started but not yet led to equal rights, might contribute to an increased likel thood of worries about or d1sapproval of drinking.

Acquired tolerance did not have the expected influence on harmful effects, probably because duration of present consumption is not a valid indicator for acquired tolerance. More specific analysis showed, however, that duration of present consumption is of influence on one category of hamful effects: psychological dependence. Those who drink the same amount of alcohol for a shorter time had a higher score on psychological dependence. The following new hypothes1s was formulated: those who recently started heavy drinking, are st111 more inclined to appreclate the tenslon-reducing effects of alcohol as a solution for their problems.

The influence of the duration of present consumption on worries and disapproval appeared for men to be opposite the hypothesis: a diminishing 11kelihood if present (heavy) consumption lasted longer. For women the results were conform the hypothesis: the longer women drink the same amounts, the more $11 k$ kely they are to worry or recelve criticism from their family.

To explain the findings for men, 1t was reasoned that heavy drinkers tend to select as friends those who do not express disapproval and that the family gets tired of criticizing if they notice that it does not result in any change in drinking. The drinker himself probably under estimates the health rlsks of his present consumption.

The varlable "degree of structure of everyday $11 \mathrm{fe}$ " had the expected Influence on Intensiflcation of drinking (defined as the $10 \%$ with the highest consumption), harmful effects and disapproval of frlends.

The use of $\log 1$ t-analysis to analyze the Influence of the degree of stmucture of everyday life on intensiflcation of drinking, showed that the influence is $u$-shaped rather than 11nea1r. Those with a less-structured everyday $11 \mathrm{fe}$ are overrepresented in the category of the very 11ght drinkers as well as the category of heavy drinkers. The same was 
found when the influence of the three Indicators for structure of everyday life, outdoor work, partner, care for children, were analysed separately.

The Influence of structure of everyday life on worrles appeared to be contrary to the original hypothesis. A new hypothesis was formulated whlch stated that if there are more people dependent on an adequate performance of position roles, the likelihood of worrles about drinking is higher.

The extent to which there are differences in intensification of drinking and vulnerabllity for harmful effects according to degree of structure of everyday life, is influenced by sex and integration of drinking.

The results showed that the influence of degree of structure of everyday life on intensification and vulnerability for harmful effects, was less strong for women than for men. Probably women do experlence more social pressure to keep to moderate drinking which might influence the extent to which differences in intensification and vulnerability for harmful effects will develop.

For men in Rotterdam greater differences in intensification of drinking and vulnerability for harmful effects were found than for men in Limburg. In Limburg the better integration of alcohol use in the status role of men, might to a certain extent prevent people with a less-structured everyday life to use alcohol as compensation for lack of structure and meaning.

The degree of the integration of drinking might also influence the likelihood that people with a less structured everyday life drink for personal effects or go on binges, v1z. Influence the reporting of harmful effects at similar consumption levels.

The stronger (secularized) Calvinistic work ethos in Rotterdam possibly contributes to the greater manifest ambivalence towards and lesser integration of alcohol use in Rotterdam.

Younger men going to school drink less than young men who work. For women no differences were found. In Limburg the lower consumption of those going to school is probably due to the fact that they have less money; in Rotterdam it is probably due to the fact that the average age of those going to school is lower. 
The Influence of urbanisation on consumption level is different from what was expected: younger men from small communlties drink more than younger men from cities. For women and older men no differences in consumption according to urbanlsation are found. In a new hypothesis it is suggested that compared with citles, drinking alcohol is a much more stressed element in the status role of younger men living in small communities. 


\section{LTIERATUUR}

ADRIAANSE, H. ,Drop,M. J. ,Halfens, R. ,Philipsen,H. (1981) Leeft Nederland Oké?,R1jksuniversiteit Limburg, Maastricht

ANTONS, K. ,Schulz, W. (1976) Normales Trinken und Suchtentwicklung. Göttingen; Verslag fur Psychologle

ARMOR, D. J. ,Pollch, J. M. ,Stambul, H. B. (1976) Alcohollsm and treatment. Santa Monica, Rand Corporation

BACON, M. K. ,Barry, H. 3d. , Ch1ld, I. L. (1965) A cross cultural study of drinking, II Relations to other features of culture. Quart. J. St. Alc. ,26,29-48

BACON, M. K. (1976) Alcohol use in tribal socletles. In B. Kissin, H. Begletter (eds): The blology of alcoho1ism, vol. 4, Social Aspects of alcoholism. Plenum Press, New York

BAIL,Y,M. B. ,Haberman, P. W. , Shelnberg, J. (1966) Identifying alcoholics in population surveys; a report on re11ab1l1ty. Quart. J. St. Alc. ,27,300-315

BAILY,M. B. (1967) Some issues in epldemlologic surveys of alcoholism. Am. J. Public Health, 57, 987-995

BALES, R. F. (1946) Cultural differences in rates of alcoho11sm. Quart. J. St. Alc. , 6, 480-499

BFCKKR, J. W. ,Vink, R. (1984) Werklozen, arbeldsongeschikten en werkenden vergeleken. Soc.Cult. Planbureau, $1984, \mathrm{nr} .14$, R1JswIJk

BAZUIN,J. H. Mulder, H. C. , (1981) Gebrulk van rustgevende middelen. Gezondheld en Samenleving, 2, 11-21

BIDDLE, B. J. ,Bank, B. J. , Martin, M. M. (1980) Social determinants of adolescent drinking, what they think, what they do and what I think and do. J.St. Alc., $41,215-241$ 
BLANE,H.T.(1968) The personality of the alcohollc: Guises of dependency. Harper and Row, New York

BRUUN,K., (1959) Drinking behaviour in small groups. Finnish Foundation for Alcohol Studies, Helsinki

BRUUN, , K. , Edwards, G. , Lumio, M. , Makela , K. , Pan, L. , Popham, R. E. , Room, R. ,Schldt, W. , Skog, O.J. , Sulkumen, P. , Osterberg, E. (1975) Alcohol Control Pollcies in Public Health Perspective: Finnish Foundation for Alcohol Studies, Helsinki

CAHALAN, D., Cisin, I.H., Crossley,H.M. (1968) Measuring massed versus spaced drinking.J.St.Alc.,29,642-656

CAHALAN,D.,Cisin,I.H.,Crossley,H.M. (1969) American drinking practises, Nw.Brunswick, N.J., Rutger Centre of alcohol studies

CAHALAN,D. (1976) Problem drinkers. Jossey Bass, San Francisco

CARTWRIGHT, A.K.J. , Shaw, S.J., Spratley, T.A. (1978) The relation between per capita consumption, drinking patterns and alcohol related problems in a population sample, 1965-1974

Part $I$ : Increased consumption and changes in drinking patterns, Br.J. Addiction, 73, 237-246 Part II: Implications for alcohol Control policy. Br.J.Addiction, 73, 247-258

CASSELMAN,J.(1980) Gehospitaliseerede en gedetineerde alcohollsten, een vergelljkend input-populatieonderzoek. Gezondheld en Samenleving, 1, 102-110

CASSEIMAN, J . , Cooreman, G. , Deraeck, G. , de W1 js-Koppen, O. , Prové,W.(1982) Jongeren en alcohol. van Loghum Slaterus, Deventer

CAUDILL,B.D.,Marlatt, G.A. (1975) Modeling influences in som clal drinking, an experimental analogy. J.consulting and clin.psych., 43, 405-515 
CEIENTIANO, D.D. MacQueen, D.V.(1978a) Comparison of alcoholism prevalence rates obtained by survey and indirect estimaters. J.St.Alc.,39,420-434

CELLENTANO, D.D., Macqueen,D.V.(1978b) Rellability and validity of estimators of alcoholism prevalence.J.St. Alc. $39,869-878$

COOKE,D.J.,Allan,C.A. (1983) Self reported alcohol consumption and dissimulation in a Scottish urban sample. J.St.Alc., 44,617-629

CRAWFORD,A. (1984) The three areas revisited: unemployment and alkohol. Paper gepresenteerd op de "Alcohol epidemiology section" (I.C.A.A.), Edinburgh, Scotland, 4-8 junt, 1984

CUTLER,R.E., Storm,T. (1975) Observational study of alcohol consumption in natural settings. J.St.Alc., $36,1173-1183$

DAVIES, P.,Walsh,D. (1983) Alcohol problems and alcohol control in Europe. Croom Helm, London, Canberra

DERRICCO,P.A.,Garlington,W.K.(1977) The effects of modeling and disclosure of experimenter's intent on drinking rate of college students. Addictive behaviours, 2,135-139

DIXON, W.J. , Brown, M. B. , Engelman, L., Frane, J.W. ,H1ll, M. A. , Jennrich,J.W.,Toperek, JD. (1981) B.M.P.D. Stat1st1cal Sof tware, Univ of Calif.Press, Berkely, Los Angeles, Iondon

DROP,M.J.(1979) Arbeldsverdeling, normatieve integratie en typen van af'wljkend gedrag. dissertatie Rijksunfversite1t Lumburg, Maastricht

DUFFY,J.C. (1977) Alcohol consumption, Alcoholism and excesslve drinking; errors in estimates from consumption figures. Intern.J. of epidemiology, $6,375-379$ 
DURKAEIM,E. (1965) The division of labour in society. Free Press, New York

DIJK,W.K.,van (1976) Alcohollsme, een veelzijdig verschijnsel. T.Alc.Drugs, 2, 26-32

DI.JK,W.K., van (1978) Het miskende beeld van de alcoholist. In: Alcoholisme, congres van de Hoytema Stichting, Enschede

EDWARDS, G. ,Chandler, J., Hensman, C. (1972b) Drinking in a London suburb II, correlates of trouble with drinking among men. Quart.J.St.Alc., Supplement no.6, 94-119

EDWARDS, G. ,Hensman, C. ,Peto, J.(1972, c) Drinkting in a London suburb III, Comparisons of drinking troubles among men and women. Quart.J.St.Alc., supplement no. $6,120-128$

EDWARDS, G . , Hawker , A ., Hensman, C. , Peto , J. , W1lliamson, V . (1973) Alcoholics known and unknown to agencies: epidemiological studies in a London suburb. $\mathrm{Br} . J \cdot$ Psychfatry, 123, 169-183

EDWARDS,G. ,Kyle, E., Nicholls, P. (1974) Alcohollcs admitted to four hospitals in England; Social Class and the interaction of alcoholics with the treatmerit. system. Quart.J.St.Alc., 35,499-522

EDWARDS,G(1977) The alcohol dependence syndrome: usefulness of an 1dea. In:G. Edwards, M.Grant(eds), Alcohollsm, new knowledge, new responses. Croom HeIm, London

EPEN,J.J.van (1974) Compendium drugverslaving en alkoholisme. Agon-Elsevier, Amsterdam

EVENSON, R.C. , Altman, H., Stellen, I.W., Knowles, R.R. (1973) Factors in the description and grouping of alcoholics. Am.J.Psychlatry, 130, 49-54 
FINEBERG,S.E. (1980) The analysis of cross-classifled categorical data. M.I.T.-press, Cambridge, Massachusetts; London-England

FITZGERALD, J.L., Mulford, H.A. (1981) the prevalence and extent of drinking in Iowa, 1979. J.St.Alc., 42, $38-47$

FITZGERALD, J.L., Mulford, H.A. (1981) Soc1al attributes, problem drinking and alcoholism treatment contacts: labeling versus soclal etiology. J.St. Alc., 42, 403-413

FRANKEL, B.G., Wh1tehead, R.C.(1981) Drinking and damage. Rutger Centre for Alcohol Studies, no. 14, New Brunswick, New Yersey

GADOUREK,I. (1963) Riskante gewoonten en zorg voor elgen welzifn. Wolters, Groningen

GARLINGTON,W.K.,Derrico, D.A. (1977) The effects of modelling en drinking rate. J. Applied Behaviour Analysis, 10

GARREISEN,H.F.L.(1982) Probleemdrinken, onderzoek in Rotterdam; basisgegevens voor een alcoholbeleld. G.G. en G.D.-Rotterdam, afdeling G.V.O.

GARRETSEN,H.F.L.(1983) Probleemdrinken, prevalentiebepaling, beInvloedende faktoren en preventiemogelijkheden. Theoretiese overwegingen en onderzoek in Rotterdam. Swets en Zeltlinger, Lisse

GARRETSEN,H.F.L.,Knibbe,R.A. (1983) Alcohol prevalentieonderzoek Rotterdam/Limburg. Ministerle van Welz1jn, Volksgezondheld en Cultuur, Leidschendam

GERHARDT,U.(1971) Rollenanalyse als kritische Sozlologie. Luchterhand Verslag, Neuwied, Berlin

GIBBS, L.E., (1980) A classification of alcoholics relevant to type-specific treatment. Int.J.Addiction,15, $461-488$ 
GRUCHOW,H.W.,PIm, A.A. ,Hoffmann,R.G.(1983) Alcohol consumption and ischemic heart disease mortality:are time-serles correlations meaningful? Am.J. Ep1d., 118,641-650

GROSVELD,J.A.M., van Doyen,D. (1982) De verstoorde werkrelatie, rijden onder invloed van alcohol en geneesmiddelengebrulk. Vakgroep arbelds- en organlsatiepsychologle. Katholieke Hogeschool TIlburg

HAUGE, R. (1978) Alcohol research in Norway. Nation. Institute, for Alc.Research, Oslo

HAUGE, R. , Irgens-Jensen, $0 .(1984)$ The relationsh1p between alcohol consumption and negative consequences of drinking in four scandinavian countries. Paper gepresenteerd op het "Intemational Council on Alcohol and addictions, Alcohol epldemiology Section", Edinburgh, 4-8 juni 1984

HIGGINS,R.L. (1976) Experimental investigations of tension reduction models of alcoholism. In: G. Goldstein, C. Neuringer (eds), empirlcal studies on alcoholism. Ballinger publishing Company, Cambridge

HINGSON, R. , Scotch, N. , Day, N. , Culbert, A. (1980) Recognizing and seeking help for drinking problems. J.St.Alc., $41,1102-1117$

HINGSON, R., Mang1one, T., Meyer's, A., Scotch, N. (1982) Seek1ng help for drinking problems. J.St.Alc.,43, $273-288$

HORE,B.D., WIlkins, R.H.(1976) A general practise study of the commonest presenting symptoms of alcohol1sm. J. of the royal college for general practitioners, $26,140-142$ 
HORN, G.H.M.M.ten (1976) De dienstverlening aan mensen met alcohol of drugproblemen door instellingen voor de geestelijke gezondheidszorg, T.soc.geneesk., $54,806-809$

HORTON, D. (1943) The functions of alcohol in primitive socleties: A cross-cultural study. Quart.J.St. Alc. , 4,199-320

JAGER, H.de, Mok, A.C.(1978) Grondbeginselen der sociologie. Stenfert/Kroese b.v. Leiden/Antwerpen

JANSSEN, J. ,Voestermans, P. (1978) De vergmuisde universiteit, diss. Katholieke Universiteit Nijmegen

JELLINEK,E.M.(1946) Phases in the drinking history of alcohollcs. Analysis of a survey conducted by the official organ of Alcoholics Anonymous. Quart. J.St.Alc., 7,1-88

JESSEN,J.L.(1974) Medische consumptie, Groningen

JONES,M.C. (1968) Personality correlates and antecedents of drinking patterns in adult males. $J$. Consulting and Clin. Psych., 32, 2-12

KILTY,K.M.(1983) Styles of drinking and types of drinkers. J.St.Alc. , 44,797-816

KLATSKY,A.L. (1983) Alcohol, cardiovascular disease and mortality: is moderate drinking healthier than abstinence?. In:Alcohol, Health and Soclety, T.N.O.-Zelst

KNIBBE,R.A. (1982) Probleemdrinken in Limburg, RIjksuntversiteit Limburg, Maastricht

KNIBBE,R.A.,Meyers,J.M. (1983) Enkele aspekten van hulpverlening aan probleemdrinkers. T.Alc., Drugs, 9,68-75 
KNIBBE, R.A. (1984) The development of allcohol consumption in the Netherlands; paper voor de 'Alcohol eptdemiology section" (I.C.A.A.) Edinburgh, Scotland, 4-8 junt, 1984

KNIBBE,R.A.,Drop,M.J., van Reek,J. (1984) The development of new drinkting styles in the Netherlands in the past 25 years. Actes de la Rencontre Internationale "Cultures, manières de bolre et alcoholisme", Bretagne, Alcohol et Santé, Remnes

KNIPSCHILD, P. (1982) Alkohol als hartversterker, Hart Bulletin, 24-32

KNUPFER,G.(1967) The epidemiology of problem drinking. Am. J.Pub1.Health, 57,972-986

KOK,A.F.W. (1979) Vrijwillige en onvrifwllilge opnemingen ten gevolge van alkohol en drugsverslaving in $\mathrm{Ne}-$ derlandse Psychiatriese ziekenhuizen. T.Alc., Drugs, 5, 55-59

LEDERMANN, S. (1956) Alcool, Alcoollsme, Alcoolisation, Données scletifiques de caractère physiologique, economique et soclal.Presses untversitaires de France, Parls

I.EDERMANN, S. (1964) Alcool, Alcoolisme, Alcoolisation;mortalité, morbldité, accidents de travial. Institut $\mathrm{Na}-$ tional d'études demographiques, Paris

LINT,J.de,Schmidt,W.(1968) The distribution of alcohol consumption in ontario.Quart.J.St.Alc.,29,968-973

LINT,J.de,Schmidt,W.(1971) Consumption averages and alcoholism prevalence:a brief review of epidemiolo gical Investigations.Br.J.Addiction, 66,97-107

LINT.J.de, Schmldt, W.(1976)Alcoholism and mortality. In:B. Kissin,H.Begletter(eds.) The blology of alcoholism.Plenum Press, New York, London 
MAKELA, K. (1975) Consumption level and cultural drinking patterns as determinants of alcohol problems. J.Drug issues, 344-357

MAKELA, K. (1983) the uses of alcohol and thelr cultural regulation. Acta Sociologica, 26,21-31

MCKIRNAN,D.J.(1977) A communtty approach to the recognttion of alcohol abuse:the drinking norms of three Montreal Communtties.Canad.J.Behav.Science, $9,108-122$

MCKIRNAN,D.J.(1978) Cormunlty perspectives on devlance:some factors in the definition of alcohol abuse. Am. J.Communtty Psych., 6,219-238

MCCORD, W.,McCord, J. (1960) Orlgins of alcohollsm, Callfornia, 1960

MERENS-RIEDSTRA,H.S.(1981) Leven zonder werk; een soclaal wetenschappelijk onderzoek naar arbeldsongeschiktheid. dissertatie RIjksuniversitelt Limburg

MEYERS,J.M.(1982) Hulpverlenende instellingen en probleemdrinkers in Ilmburg; verslag van onderzoeksstage; RIJksuniversiteit Limburg, medische soclologie

MILLER,G.H., Agnew,N.(1974) The Ledermann model of alcohol consumption. Quart.J.St.Alc. , 35,877-898

MORRISON,D.G.(1969) On the interpretation of discriminant analysis.J.Market1ng Research VI,156-163

MULFORD,H.A.,Miller,D.E.(1959) Drinking in Iowa: a social cultural distribution of drinkers.Quart.J.St. Alc. $, 20,704-726$

MULFORD,H.A.,Miller,D.E., (1963) The prevalence and extent of drinking in Iowa, 1961.Quart.J.St.Alc., 24-39-53 
MULFORD, H.A.Wllson, R.W.(1966) Identifying problem drinkers In a household health survey. National Centre for Health Statistios, series.2, no 16

MULFORD, H.A.(1977) Stages in the alcohol1c process.J.St. A.c. $38,563-583$

NIE, N.H. ,Hadla1 Hull, C., Jenkins, J.G. , Stelnbrenner, K. , Bent, D.H.(1975) S.P.S.S., sec.ed., MacGraw-H111 Book Company

PERNANEN, K. (1974) Val1dity of survey data on alcohol use. In:R.J.Gibblins (ed.) Research advances in alcohol and drug problems, vol. I, New York

PETERS,H.J.(1982) Typologle alkoholverslaafden, I: opzet van een verkennend onderzoek en verslag van een proefanalyse.Jellinekcentrum, afdl.evalut1e, Amsterdam

PHIIIPSEN,H. (1976) Maatschapp1 j en verslaving. In: Cahlers voor biowetenschappen, 3

PHILIPSEN,H. (1980) Leven onder Pax Alcoholica.In: H. de Baere, J. Casselman (eds.), Het Alcohol probleem. Stafleu, Alphen a.d. Rijn

PHILIPSEN,H.,Knibbe,R.A. van Reek, J. (1984) Alcoholgebmik in Nederland als soclaal verschljnsel. Voeding, 45, $10-15$

PITTMAN,D.J., Sntjder, C.R.(1962) Soclety, culture and drinking pattems, John W1ley, New York

PLAUT, T.T.A.(1967)Alcohol problems. Oxford university Press, New York

POKOLAINEN, K., Kärkkalinen,P. (1983) Dlary gives more accurate Information about alcohol consumption than questionaire. Drug and alc. Dependence, $1 \mathrm{~h}$, 209-216 
POPHAM,R.E.(1970) Validity of survey questions on drinking. Drinking and drug practises surveyer, 7

POPHAM,R.E., Schmidt, W., de Lint,J.(1976) The effects of legal restraint on drinking. In:B.KIssin,H.Begleiter (eds.), the blology of alcoholism,IV.Plenum publishing corporation, New York

REEK,J.van, Knibbe, R.A.,Drop, M.J. (1983) Ontwikkelingen in alcoholgebrulk in Nederland: 1958-1981.T. soc.gezondh.zorg, 25,954-960

REEK,J.van, (1983) Rookgedrag in Nederland van 1958-1982. 'T.alc. ,drugs , 9, 99-103

REID,J.B. (1978) Study of drinking in natural settings. In:G.A.Marlatt,P.E., Nathan (eds.), Behavioral approaches to alcoholism. Rutger Center of alcohol studies, New Brunswick

ROBINS, L.N.(1974) Alcoholism and labeling theory. In: W.R.Gove (ed.) The labeling of deviance, evaluating a perspective.John Wiley, New York

ROBINSON,D. (1976) From drinking to alcoholism, a sociological commentary. John Wiley, London

ROOM,R.(1972) Drinking patterns in large U.S. cities. Quart. J.St.Alc., 33, 28-57

ROOM,R. (1977) Measurement and distribution of drinking pattems and problems in general populations. In: G. Edwards e.a., (eds.) Alcohol related disabilities, W.H.O., Geneve

ROOYEN, L.VAN(1981) Problem drinking among students in a Dutch untversity. Gezondh. en Samenl., 2,65-77

SAUNDERS,W.M., Kershaw,P.W.(1978) The prevalence of problem drinking and alcoholism in the West of Scotland. Br.J.Psychtatry, 133,493-499 
SELZER,M.L.(1980) Alcohollsm and alcohollc psychoses. In:H.I.Kaplan, A.M.Freednan,B.J. Saddock (eds.) comprehensive textbook of psychiatry. Williams and Wllklins, Bal timore

SCHIPPERS,G.M.(1981) Alcoholgebruik en alkoholgerelateerde problematiek. Swets en Zeltinger BV, IHsse

SCHMIDI,W., de Lint,J.(1970) Estimating the prevalence of alcohollsm from alcohol consumption and mortal1ty data. Quart.J.St.Alc.,31,957-964

SCHMIDT, W., (1977) C1rrhosis and alcohol consumption: an epldemiological perspective. In: G. Edwards, M.Grant (eds.), Alcohol1sm, new knowledge and new responses, Croom Helm London

SCHUURMAN, J.H., Passchler, J., de Haes,W.F.M. (1980) Een onderzoek naar faktoren die samenhangen met het rook- en drinkgedrag van scholleren. T.Soc.Geneesk., 58: 718-729

SKOG,0.J.(1977) Does the same distributional model for alcohol consumption apply to both male and female populations. Statens Institutt for alkoholforskning, osio

SKOG,0.J.(1977) on the distribution of alcohol consumption. In: Maudsley Hospital, Alcohol education Centre: The Ledermann curve; report of a symposium held in London, 6-7 Jan.,1977

SKOG,0.J.(1979) A note on the distribution of alcohol consumption: Gamma vs. Lognomal distributions. A reply to Guttorp and Song. Drinking and drug Practlces Surveyor, $13,3-30$

SKOG,0.J.(1980) Social interaction and the distribution of alcohol consumption.J.Drug 1ssues, $11,71-92$

SKOG,O.J.(1981) Comments; the prevalence and extent of drinking in Iowa, 1979, J.St.alc., 42,689-695 
SKOG,0.J.(1981) Drinking behaviour in small groups: the relation between groups size and consumption level.In:T.C.Harford,L.S.Gaines (eds.), soclal drinking contexts, Research monograph, 7, Nat. Inst. on Alc. abuse, Rockville

SKOG,O.J.,(1982) The distribution of alcohol consumption, part.I: a critical discussion of the Ledermann model. Statens Institutt for alkoholforskning, Oslo.

part.II (1983): a review of the first wave of empirical studies

SKOG,O.J.,(1983) Estimating magnitudes and trends of alcohol related problems: a critical appraisal. In: Alcohol, Health and Soclety, T.N.O.,Zeist

SKOG,O.J., (1983) Methodoligical problems in the analysis of temporal covariation between alcohol consumption and ischemic heart diseases. Br.J.Addiction, $78,152-172$

SKOLNICK,J.H.,(1958) Religtous affiliation and drinking behaviour. Quart.J.St.Alc., 19,452-470

STRAUSS, R. , Bacon, S.D. (1953) Drinking in college. New Haven, Yale University Press

SULKUNEN,P.(1974) Drinking patterns and the level of alcohol consumption: an international overview. In: R.J. Gibbins, Y. Israel, H. Kalant, R.E. Popham, W. Schmidt, R.G. Smart (eds.), Research advances in alcohol and drug problems, vol. III, Wiley, New York

SIJLBING,G.(1978) Drink- en rookgewoonten. S.W.O.A.D., Amsterdam

TABACKNICK, B.G.,Fidel1, L.S. (1983) Using multivarlate statistics. Harper and Row, New York

TEMPEL,A.J.van den (1977) alcoholacc1jns, alcoholverbruik en consumptiebeleid. T.Alc.,Drugs, 3,50-54 
VAILLANT, G.E.(1980) Natural history of male psycholozica? health VIII, antecedents of alcoholism anc 'orality'. Am.J.Psychlatry, 31,15-22

VAILUANT,G.E.,Mliof sky,E.S.(1982) The etiology of alcohoIism, a prospective viewpoint. Am.Psychologist, $37,494-503$

VAILIANT, G.E., Gale, L. Milof'sky, E.S. (1982) Natural history of male alcoholism, II: the relationship between different diagnostic dimensions.J.St.Alc., 43, 216-232

WAL, H.J.van der (1978) Roken, drinken en cannabısgebruik door jonge mensen. T.Alc.Drugs, 3,115-126

WAL, H.J.va der (1983) Roken en drinken. Resultaten van een onderzoek onder leerlingen van het voortgezet onderwijs in de gemeente Amstelveen. T.Alc., drugs, $9,146,151$

WEBER,M.,(1947) Gesamelte Auf'satze zur Rel1gionssozlologie, deel I: J.C.B. Mohr, Tubingen

WEVER, O.R.(1976) Methoden ter schatting van het voorkomen van alcoholisme in een bevolking. T.Alc., Drugs, $2,19-25$

WEVER,O.R.,GIps,C.H.(1977) Schatting van het aantal excessleve drinkers en alcoholisten in Nederland met de Ledermann-formule, 1875 tot 1977. T.Alc., Drugs, 3, 43-49

WILKINS, R.H.(1974) The hidden alcoholic in general practise. Elek Sclence, 1974

WHIIEHEAD, P.C., Harvey, C. (1974) Explaining alcoholism: an empirical test and reformation.J. of Health and Soctal Behaviour, 15,57-64

WIISON,P.(1981) Improving the methodology of drinking surveys. The statistician, 30,159-167 
BIJLAGEN 



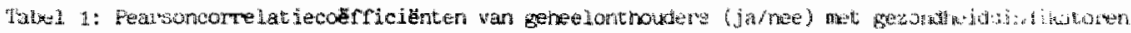

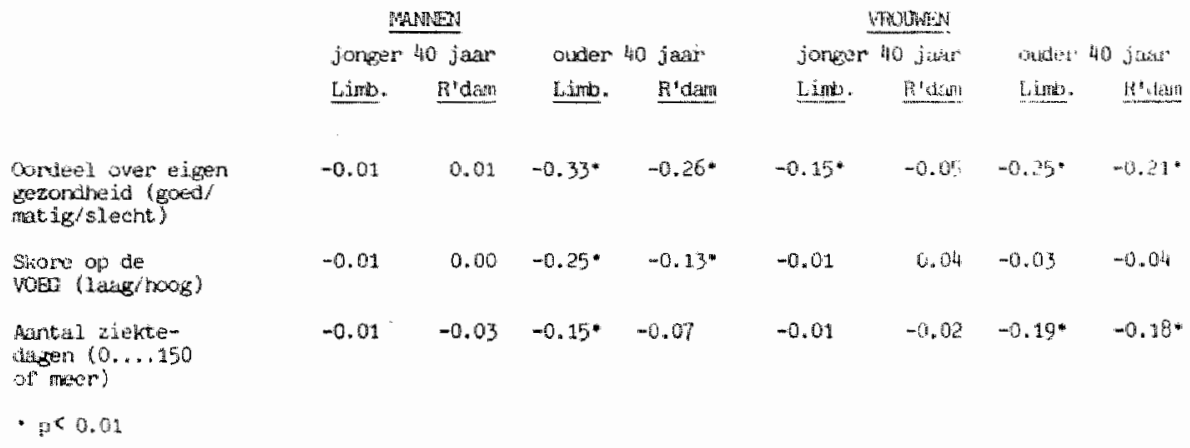


t.

角

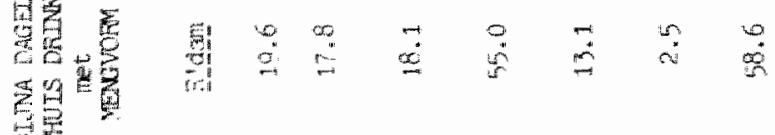

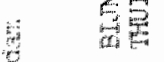

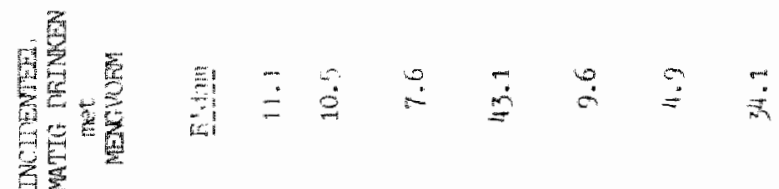

A

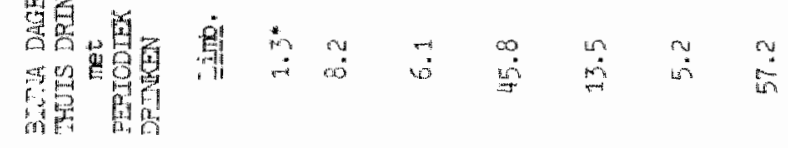

迸

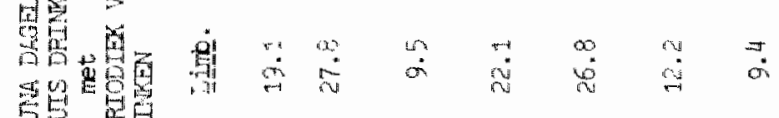
紧

.



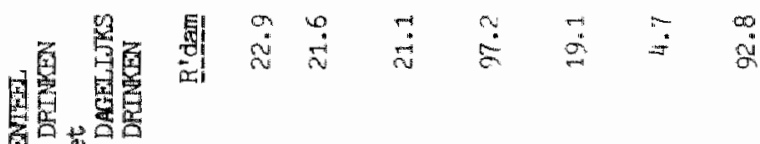

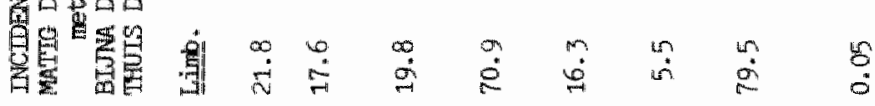

8

要

薄

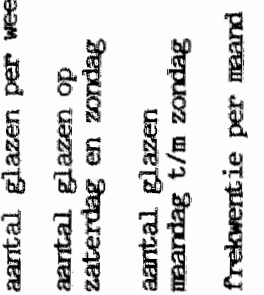

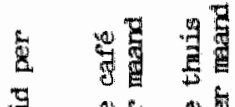

5 है

要

है 
Tabe? 3 : Skore on struktureme wan het dapeli iks bestaan naar geslacht.

\section{LTIMBURG}

Skore op strukturering dagelijks bestaan

1
1
3

Thotidet

N

\begin{tabular}{|c|c|c|c|}
\hline $\begin{array}{c}\text { MAMNEN } \\
\frac{1}{*}\end{array}$ & $\begin{array}{c}\text { YROUWEN } \\
\%\end{array}$ & $\begin{array}{c}\text { MANNWN } \\
:\end{array}$ & "SOUNA \\
\hline 3.7 & 3.4 & 5.4 & $1 . y_{3}$ \\
\hline 24.4 & 23.4 & 30.0 & 35.9 \\
\hline 24.4 & 62.9 & 9.6 & 39.3 \\
\hline 48.6 & 10.6 & 31.0 & $1 y_{-4}$ \\
\hline $\begin{array}{l}100 \% \\
8 \%\end{array}$ & $\begin{array}{l}100 \% \\
101\end{array}$ & $\begin{array}{l}1010 x^{\circ} \\
80188^{\circ}\end{array}$ & $\begin{array}{l}100 \% 0 \\
701\end{array}$ \\
\hline
\end{tabular}

ROTIEPDAM 


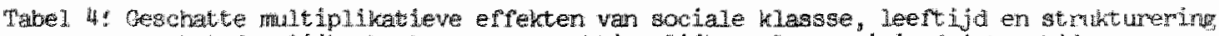

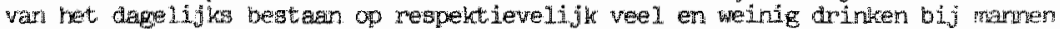

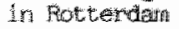

4. gi. per mek

va. $1-21$ gl. per week
21 gi. per ween Ys. $1-2$.

\begin{tabular}{|c|c|c|c|}
\hline sociale kl. & 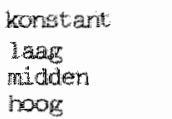 & $\begin{array}{l}0.21 \\
1.3 \\
1.1 \\
0.71\end{array}$ & $\begin{array}{l}\therefore \cdots \\
3.1 \\
\therefore .5 \\
\therefore .5\end{array}$ \\
\hline leertijid & $\begin{array}{r}16-29 \\
\geqslant 30\end{array}$ & $\begin{array}{l}1.0 \\
0.70\end{array}$ & 1,4 \\
\hline 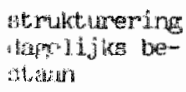 & $\begin{array}{l}0 \text { or } 1 \\
z \\
3\end{array}$ & $\begin{array}{l}.7 \\
0.00 \\
0.98\end{array}$ & $\begin{array}{l}1 \ldots \\
\cdots \\
1 . .8\end{array}$ \\
\hline $\begin{array}{l}\text { leeft } 1 j d \\
16-29\end{array}$ & $\begin{array}{l}\text { sociale kit. } \\
\text { latag } \\
\text { midden } \\
\text { hoog }\end{array}$ & $\begin{array}{l}0.96 \\
1.3 \\
0.83\end{array}$ & $\begin{array}{l}1.0 \\
1.0 \\
0.98\end{array}$ \\
\hline 30 & $\begin{array}{l}\text { laag } \\
\text { midden } \\
\text { hoog }\end{array}$ & $\begin{array}{l}1.0 \\
0.80 \\
1.2\end{array}$ & $\begin{array}{l}1.0 \\
0.98 \\
1.0\end{array}$ \\
\hline leeficijd & $\begin{array}{l}\text { struktive- } \\
\text { ring dagel. } \\
\text { bestalan }\end{array}$ & & \\
\hline $16-29$ & $\begin{array}{l}0 \text { or } 1 \\
2 \\
3\end{array}$ & $\begin{array}{l}0.75 \\
1.2 \\
1.1\end{array}$ & $\begin{array}{l}0.76 \\
0.94 \\
1.4\end{array}$ \\
\hline 230 & $\begin{array}{l}0 \text { of } 1 \\
2 \\
3\end{array}$ & $\begin{array}{l}1.3 \\
0.81 \\
0.93\end{array}$ & $\begin{array}{l}1.3 \\
1.1 \\
0.71\end{array}$ \\
\hline
\end{tabular}

sociale kl. strukture-

ring dagel. bestaan

$\begin{array}{llll} & 0 \text { of } 1 & 0.78 & 1.1 \\ \text { ladag } & 2 & 1.6 & 1.1 \\ & 3 & 0.82 & 0.82 \\ & 0 & 1.1 & 0.75 \\ \text { midden } & 2 & 0.65 & 0.84 \\ & 3 & 1.4 & 1.6 \\ & 0 \text { of } 1 & 1.1 & 1.2 \\ \text { hoogs } & 2 & 1.0 & 1.1 \\ & 3 & 0.88 & 0.77\end{array}$


(1 el. per week

vs. 1-21 kl.per meek $\geqslant 21 \mathrm{gl}$. per week

vs. $1-21$ gil. per week

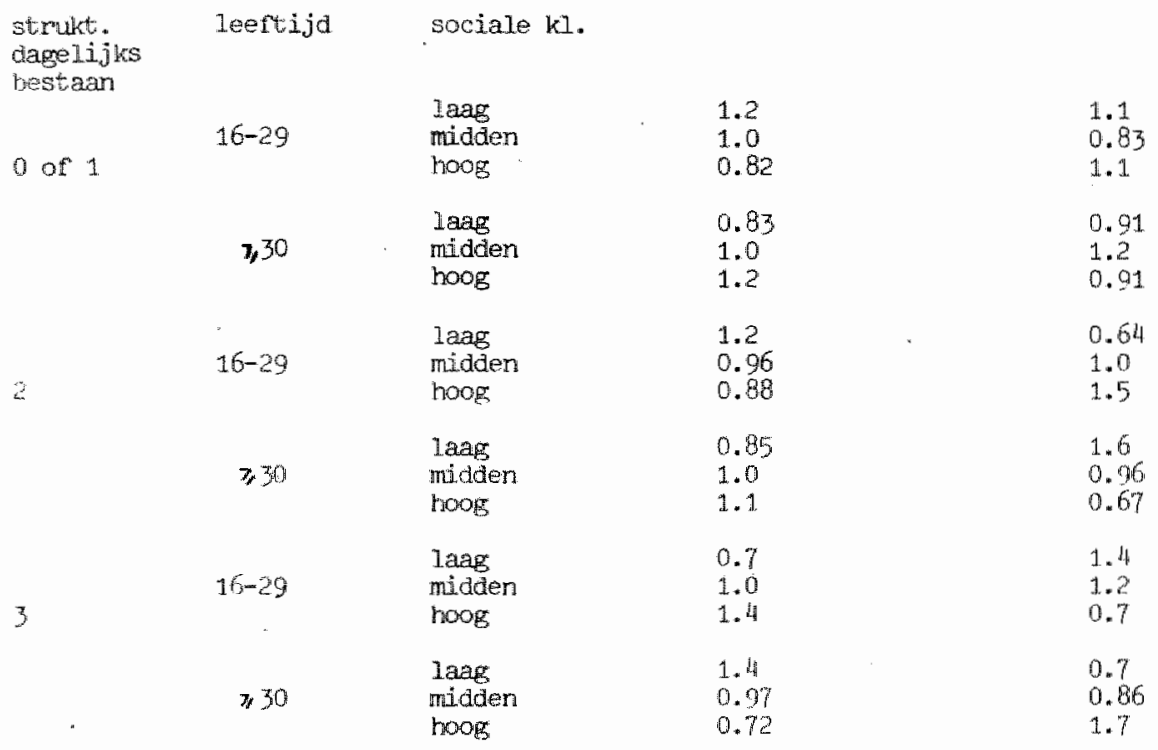




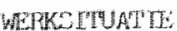
MAMEN

werkegend

ariag iduonges chatk

Fenens iloned ir

\section{WROUNWW}

werkzowkend (alleen Linb.)

30 jagn of ander MANNWEN

\section{Vivuwen}

r.sintwurg

WRCXWAIN

Botererdan

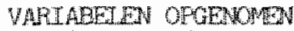

DN DE MARE

wathen. (jadnee), soc. Whasse (1adimidien) leatid $(<0$ jatar. $\geqslant 30$ jaxi

arb.ong. (ja/nes) groz. sit (zonder partner get. met thuisw. kinderem/ gehuwd met kinderen burtenshis)

gepens. (jalnee), ger. sit, (gen. met thuisw. Kindemer/ geh. met buttershuiswoneride kinderen

werlez. (ja/nee) soc. klasse (laak, midden, hoog)

gez. oit: (nooit geh. met parther zonder kinderen/met partner an thus inwornde kinderen

\$oc $\cdot k]$. (ladg/midden/hoog)

ger.sit, (nooit geh./

met parther zonder kinderery ret pantner en thuisw. kinderen met parther en buiternsizus wonende kinderen) soc.kI. ( labg/ridden/hocg)

gez.sit (met parther, zonder kimarem/met partner en thuisw. Kinderen/met partner en buitenshuis wonende kinderen 300. $\mathrm{kl}$. (1amg/midden/hoog)

idem als mouwen in Lumburs met het rersohil dat gescheidenan en weduwes als aparte kategonigen van gezirussituatie in de amalyae zijn opgenom

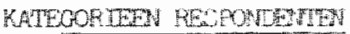
DTTOESLOLEN WA AMAINAE

hogere klasse; arbeidsongeschint of pepersioneerd

jonper dar 30 jasm vichan

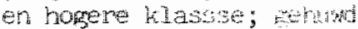
zonder kinderen

jonger ban 50 jata; midmen hopere Klasse; zonder partiner, wet parterer zonder" kinderen

wder don 30 jaar; arhe insorgesentht of pepensichomet

getherdenen, weduwes

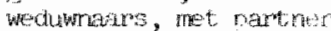
eru buitenshulis wonerde kimbren

gescheidenen, weduwnan werkookenden, arbeidson geschikten on gepensionear den

nooit gehuwden, sesche idemert en weduwes; werkzoforn, ant. onr. perensionermin 
Bijjlage Konstruktie index voor nadelige gewolgem

Psychologiese afhankelizhlueid:

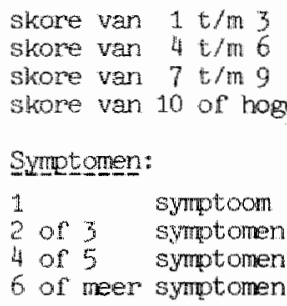

-1 punt op index

- 2 punter op index

- 3 punten op index

- 4 punten op index

Gezondheid/onge hukken:

1 punt op gezondreld/onge lukker

2 pumien op gezondheid/ongelukker

-1 puni op index

- 2 punter op findex

- 3 punter op jndex

-4 punter op index

\section{Dronkenschap/kater:}

1 tot 6 keer aronken/kater latste halfiaar - 1 punt op index 6 tot 12 keer dronkien/kater lastate halfjar - 2 punten op index 12 tot $25 \mathrm{keer}$ dronken/kater laatste halfjaar - 3 punten op index 25 keer of vaker dronken/kater laatste halfjar - 4 punten op index

Tabel 5 : Skore op de index van nadelige gevolgen in Limburng en Rotterdarn

0 puriten

1 punt

2 puriten

3 purten

4 of 5 punten

6 of 7 punten

8 of 9 punter

10 of meer punter

Missing

\begin{tabular}{rr}
$39.4 \%$ & $48.2 \%$ \\
$22.5 \%$ & $21.5 \%$ \\
$10.9 \%$ & $9.4 \%$ \\
$8.2 \%$ & $6.7 \%$ \\
$8.6 \%$ & $4.1 \%$ \\
$3.7 \%$ & $2.6 \%$ \\
$2.0 \%$ & $1.1 \%$ \\
$1.0 \%$ & $1.2 \%$ \\
$3.5 \%$ & $5.2 \%$ \\
$-100 \%$ & $-2 \%$ \\
1545 & $100 \%$ \\
\hline
\end{tabular}


Tabel 6: Invloed van geslacht op skore op de index voor nadelige gevolgen

\section{LIMBURG}

$\begin{array}{llll}\text { som der } & \text { urij- } & \text { geniddel- } & \text { signif. } \\ \text { kwadra- } & \text { heids- } & \text { se der } \\ \text { ten } & \text { graden } & \text { kwadraten }\end{array}$

$\begin{array}{lrrrrr}\text { Konsumptienivo } & 1.411 .689 & 1 & 1.411 .689 & 349.301 & 0.000 \\ \text { Gew.lacht } & 143.460 & 1 & 143.460 & 35.497 & 0.000 \\ \text { Verklaand } & 2.069 .995 & 2 & 1.034 .998 & 256.095 & 0.000 \\ \text { tesidu } & 5.637 .8431 .395 & 4.041 & & \end{array}$

\section{ROTIERDAM}

signift.

$\begin{array}{lrrrrr}\text { Konsumptienivo } & 1.255 .486 & 1 & 1.255 .486 & 350.599 & 0.000 \\ \text { Ceslacht } & 39.995 & 1 & 39.995 & 11.169 & 0.001 \\ \text { Verklaard } & 1.525 .973 & 2 & 762.986 & 213.066 & 0.000 \\ \text { resitu } & 5.117 .220 & 1.429 & 3.581 & & \end{array}$




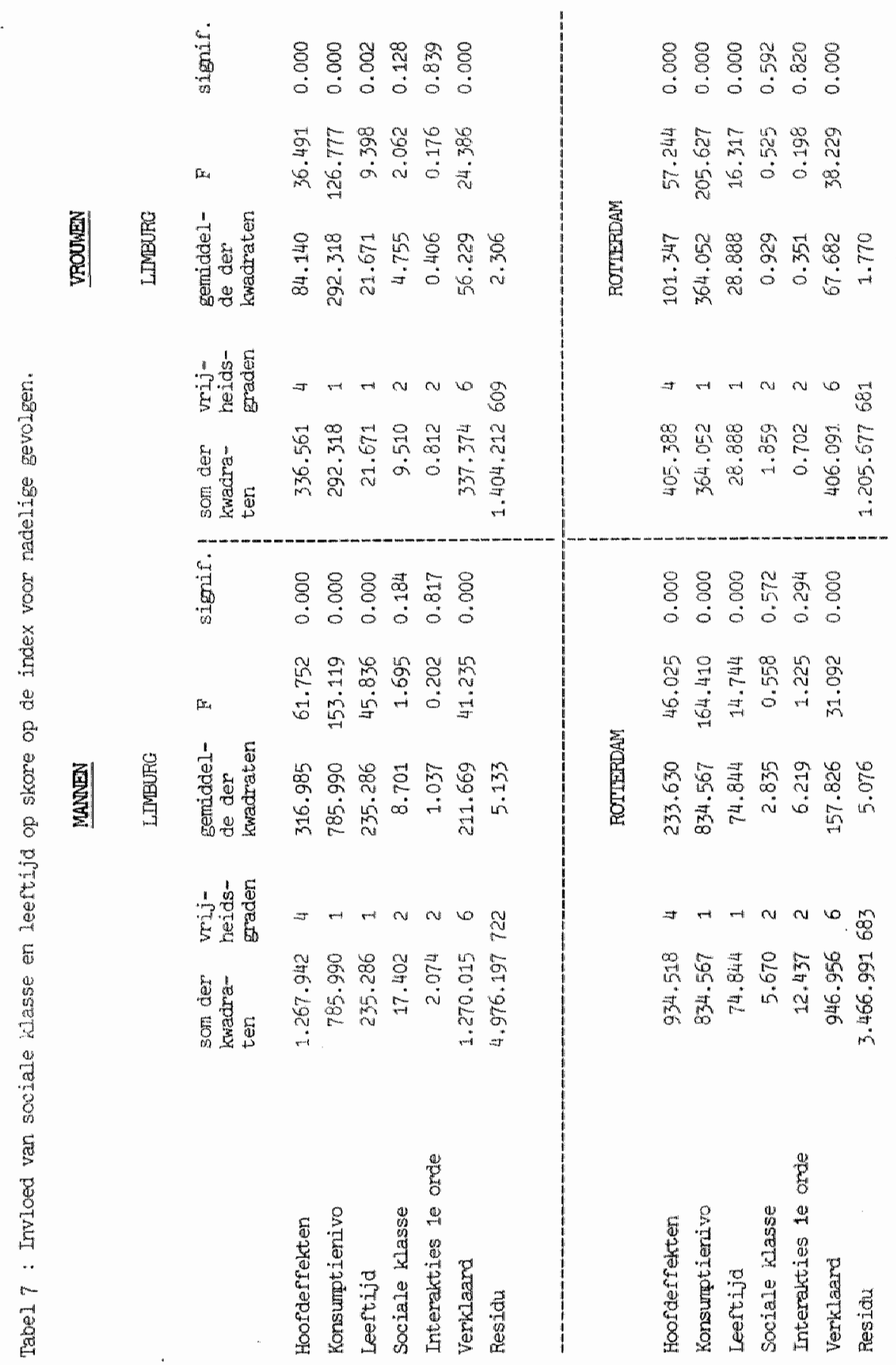




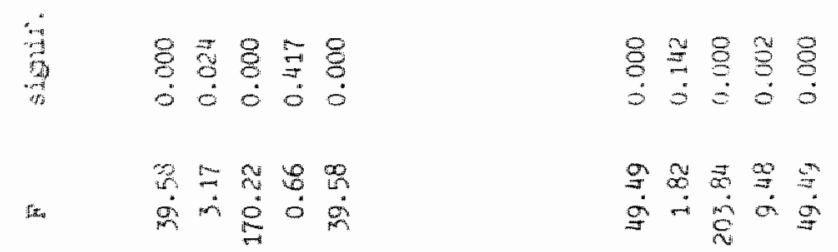

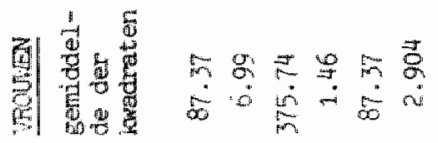

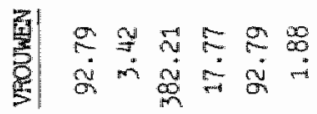

的m $\rightarrow$ -

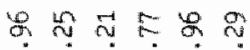

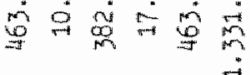

起

$\begin{array}{llll}8 & 8 & 8 & 0 \\ 0 & 8 & 8 \\ 0 & 0 & 0 & 0\end{array}$

운

$\dot{y} \dot{y} \dot{g}_{i}^{\circ} \dot{y}$

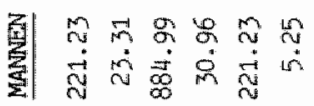

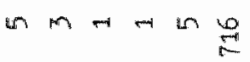

평

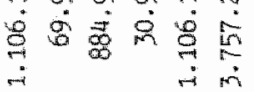

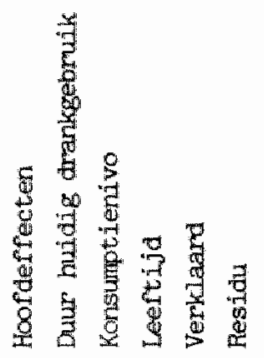




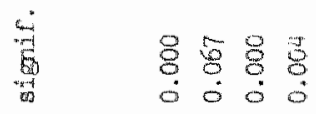

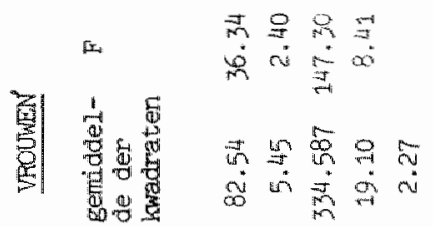

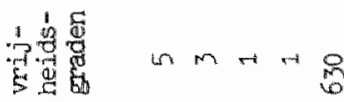

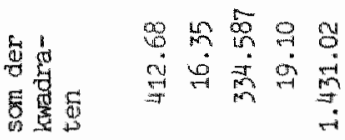

突

$\begin{array}{llll}8 & 8 & 8 & 8 \\ 0 & 8 & 8 \\ 0 & 0 & 0\end{array}$

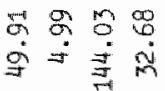

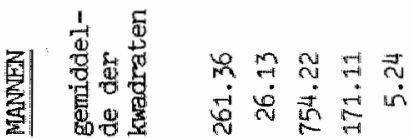

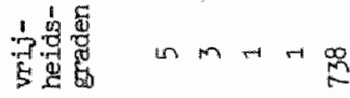

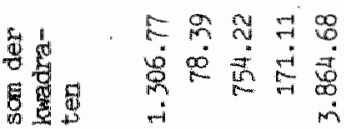

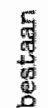

용

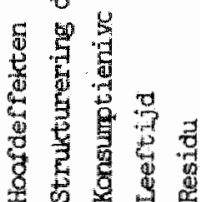

$\begin{array}{llll}8 & 8 & 8 \\ 8 & 8 & 8 & 0\end{array}$

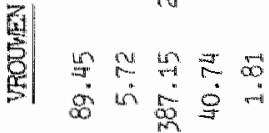

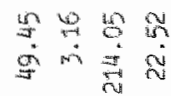

in $m$ ㄸ

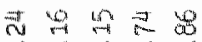

$5 \stackrel{4}{5}$

출

$\begin{array}{llll}8 & 8 & 8 & 8 \\ 0 & 0 & 0 & 0\end{array}$

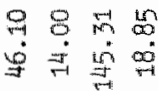

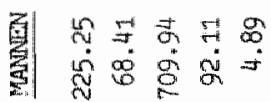

un $M+r \rightarrow \frac{m}{8}$

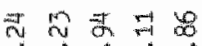

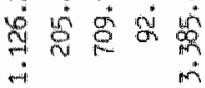

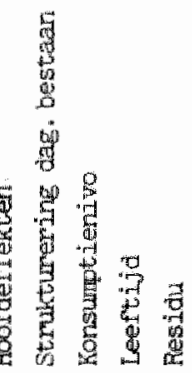




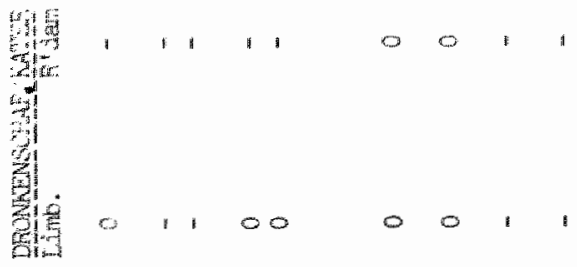

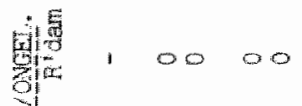

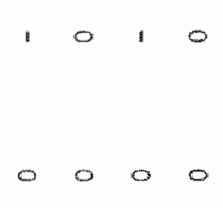

路

$\mathfrak{a}^{2}$

踪

裁

量

题:

ing

1011

0010

8

a

क्य

0000

1010

竞

10000

$\begin{array}{cccc}1 & 1 & 0 \\ & 3 & \\ 5 & 5 & 5 \\ 5 & 5 & 5\end{array}$

5

量

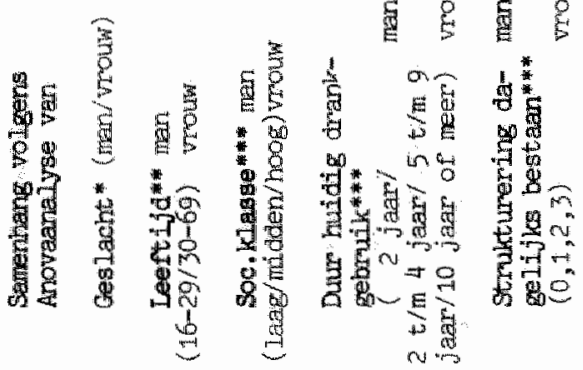

. . e s o

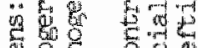
․․․ 8 क. 势 99

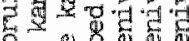
o 0 a on 8 을 둘

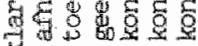

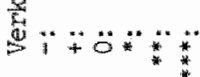


5
5
6
5
5
5

5

8

b

5

然

है

(5)

$\sum_{i=1}^{\geq}$

要

足希

g.

$7 \mathrm{x}$

8

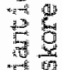

and

㩆

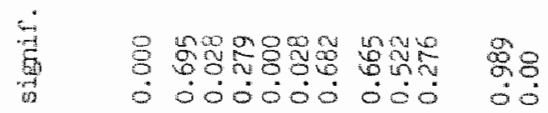
Nㅡㄴㄷㅐ

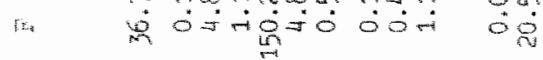

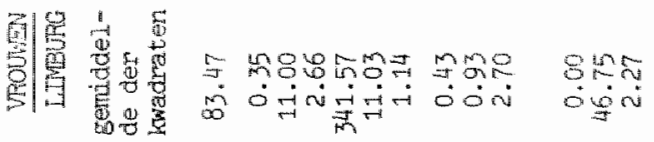

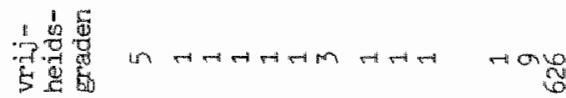

商

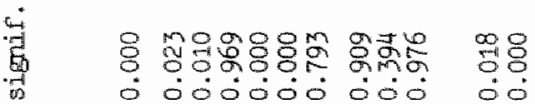

ta

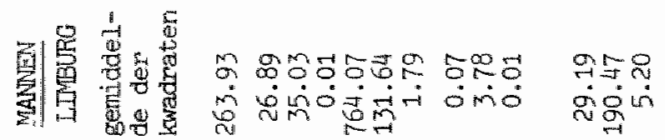

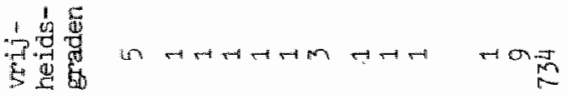

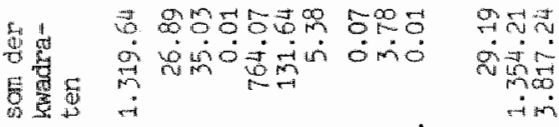

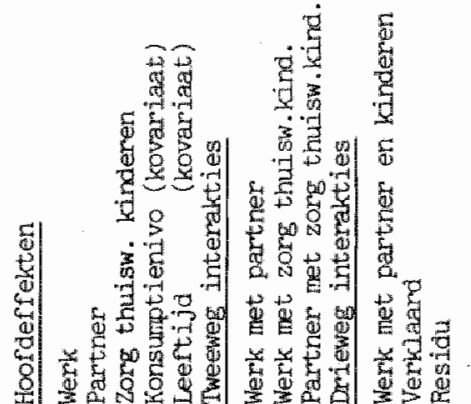

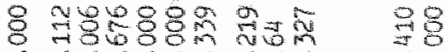

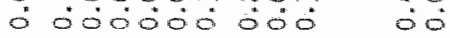

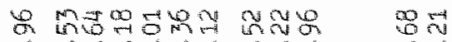

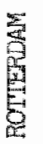

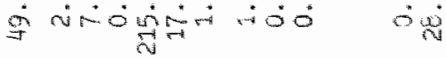

क जी

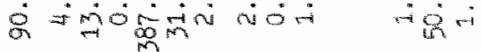

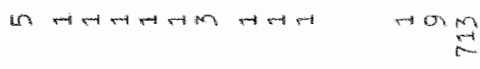

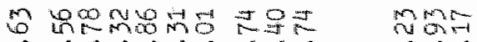

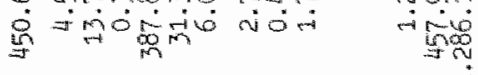

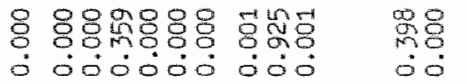

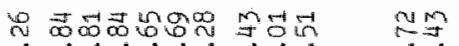
ક

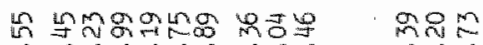

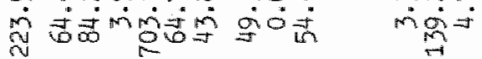

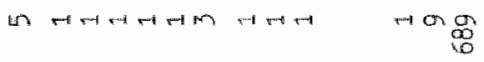

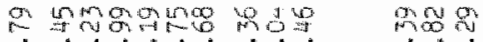

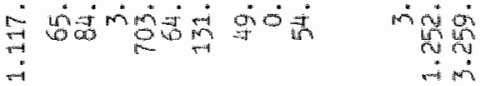

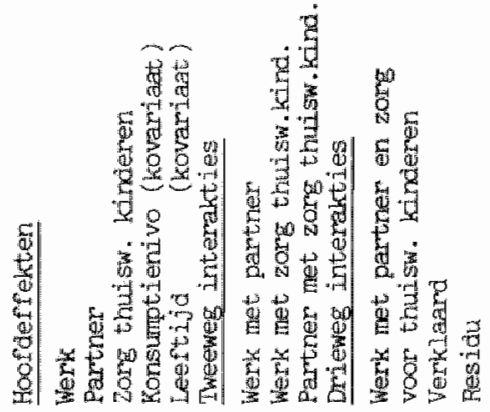


敢

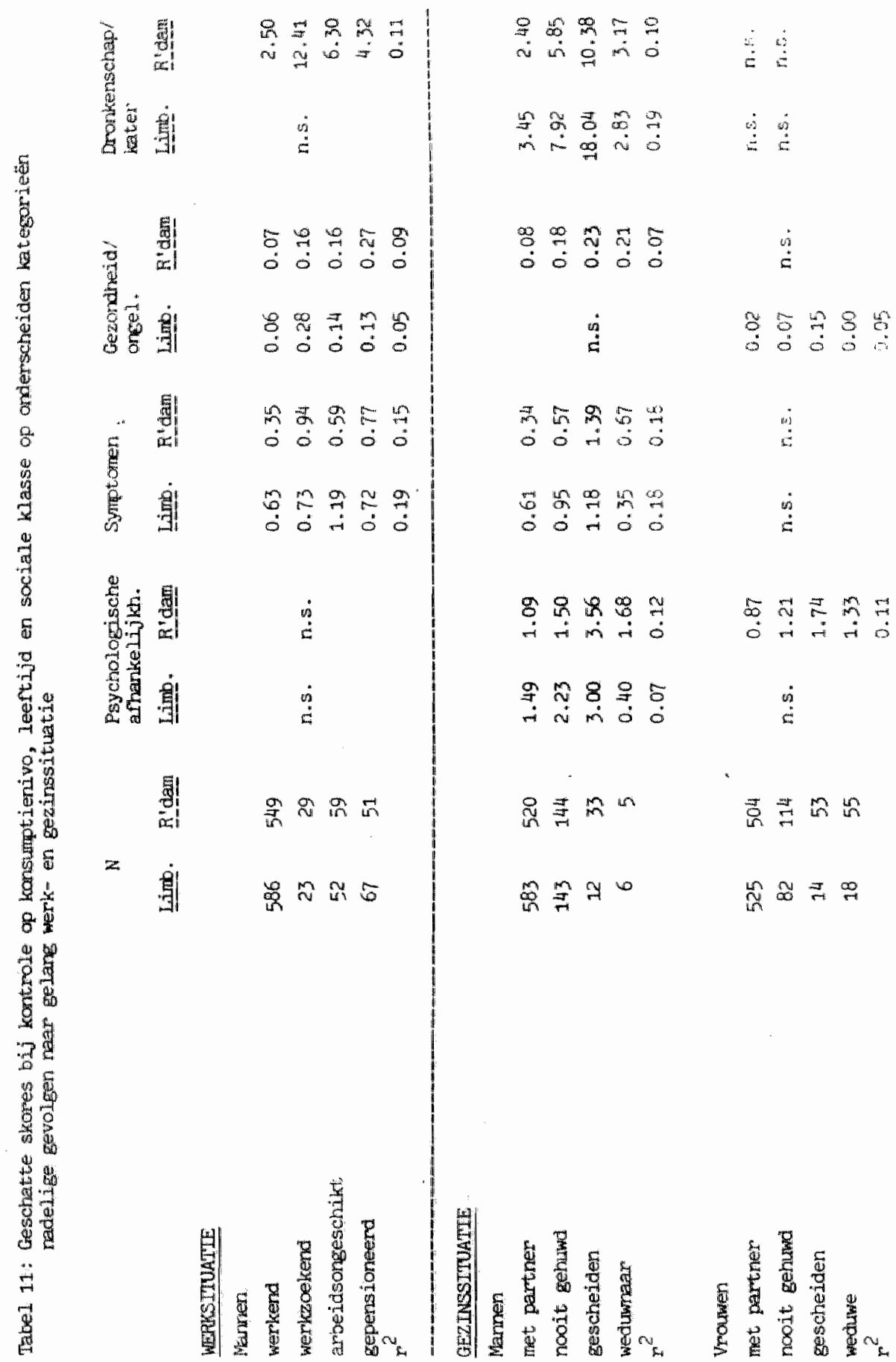


Tabe 1 12: Nulde orde korrelaties van enkele statusfaktoren met de index voor nadelige gevolgen.

LIMBURG

$-0.26$

$-0.26$

$-0.12$

n.s.

n.s.
ROITEPDAM

$-0.20$

$-0.14$

$-0.12$

n.s.

n.s. 
in

ge

$\sum_{i}$

政

in

or.

\& 0 \&

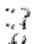

*

in

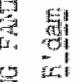

$\begin{array}{lllll}3 & \infty & \infty & \infty \\ 4 & \text { व } & \cdots & 0\end{array}$

${ }_{-1}^{m} 8 g$

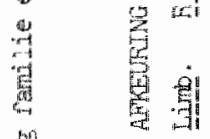

$\dot{0}$

5
$\infty$
-1

$\frac{9}{4}$

窟

-

$\dot{2}$

$\begin{array}{lll}8 & 8 \\ 0 & 8 & 0 \\ 3 & 0\end{array}$

$\dot{\square}$

a

5

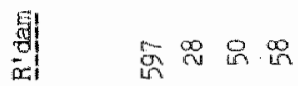

$\stackrel{F}{\Rightarrow} \Rightarrow \mathrm{m}$

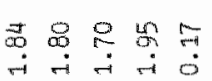

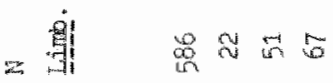

胥

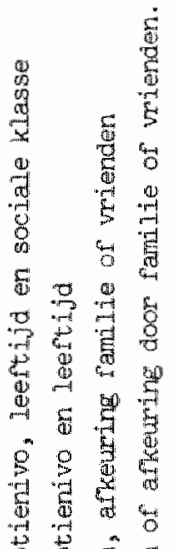

象

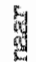

I

影

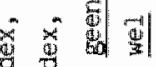

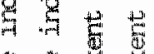

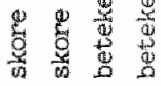

照

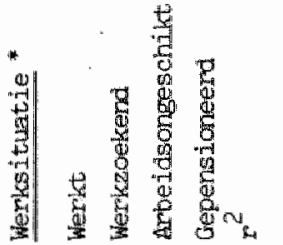


Bijlage II bij Hoofdstuk VII

Logltanalyse

analyse in fase

1. Allereerst wordt een, voor de analyse van het effekt van een bepaalde varlabele op de konsumptie, relevante deelverzameling utt alle cases (resp. een relevante subpopulatie uit de populatie) gedefiniëerd.

2. Indien blijkt dat bepaalde nivo's of kombinaties van nivo's van variabelen slecht vertegenwoordigd zijn, dan wordt de deelverzameling verder gereduceerd door die (kombinatie van) nivo's uit te sluiten.

In somige gevallen (te kleine aantallen) moet besloten worden van verdere analyse af te zien.

3. Er wordt gezocht naar het eenvoudigste loglinealre model dat bevredigend past op in 2. verkregen kruistabel. Een loglineatr model is een model voor de opbouw van de logaritme van het verwachte aantal (of proportie) per cel van de kruistabel, In additieve komponenten die samenhangen met de nivo's per vartabele resp. komblnaties van die nivo's (Interaktietermen).

4. Uitgaande van het gevonden loglineaire model worden twee logitmodellen geformuleerd. Het logitmodel is een model voor de verklaring van de logarltme van het quotlënt van de verwachte aantallen (of proporties) op twee konsumptienivo's in additleve komponenten bestaand uit hoofdeffekten en interaktieèffekten van de verklarende varlabelen.

De twee gehanteerde logitmodellen betreffen de quötienten van respektievelijk de konsumptienivo's "laag" met "midden" en "hoog" met "midden".

Voor het quotiënt van de aantallen (of proportles) geldt een met het additieve model korresponderend multiplikatief model. Omdat de daarmee samenhangende parameters direkter interpreteerbaar zf Jn, worden daarvan de waarden gegeven.

Deze waarden zijn berekend aan de hand van de loglinealre parameters. 


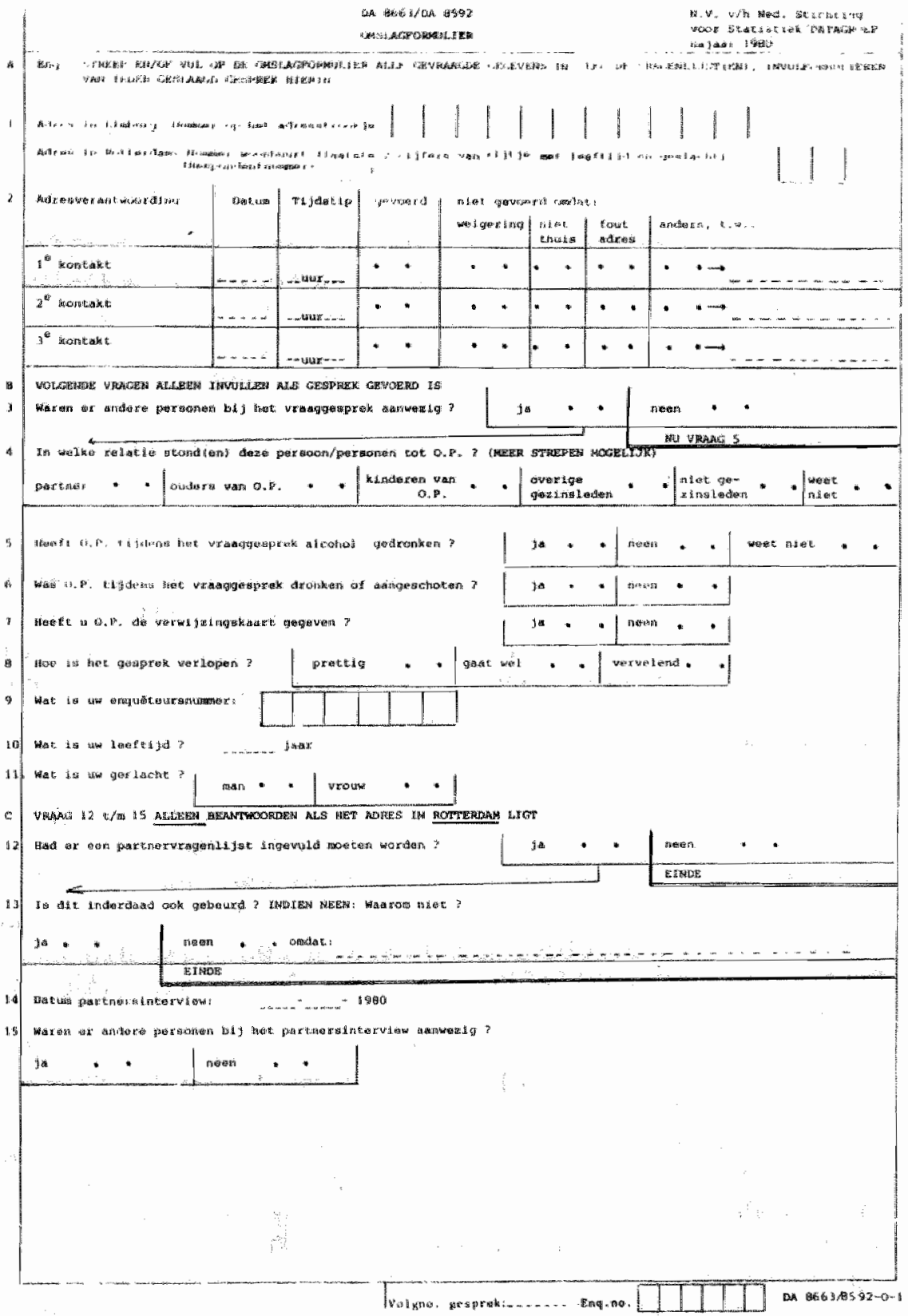


i.s.

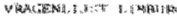

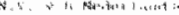

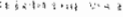

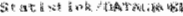

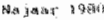

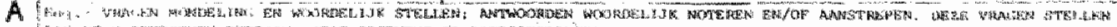

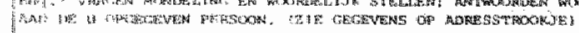

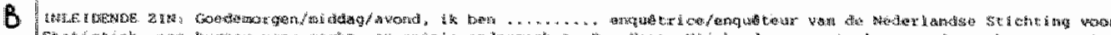

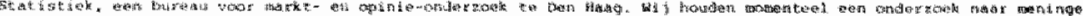

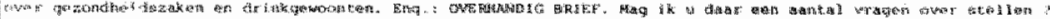

Th

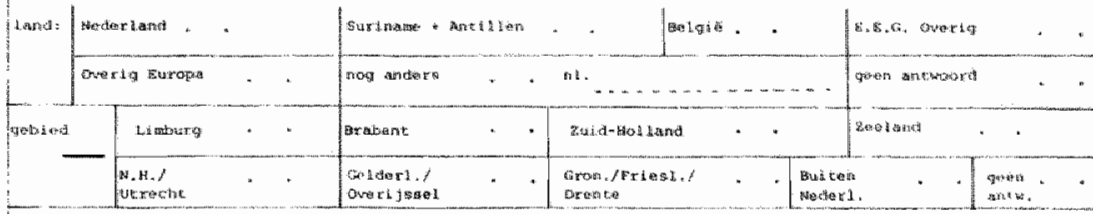

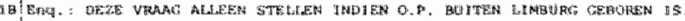

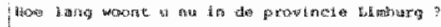

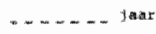

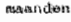

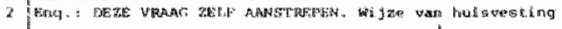

menchezingwanghy . .

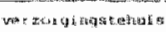

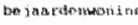

anders $\quad . \quad n$

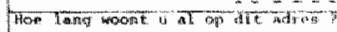

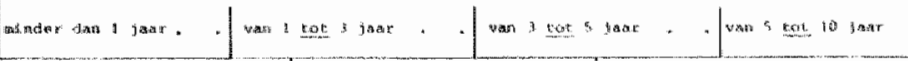

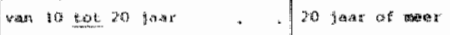

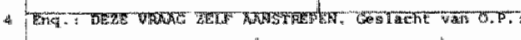

5 HAE

rrousim

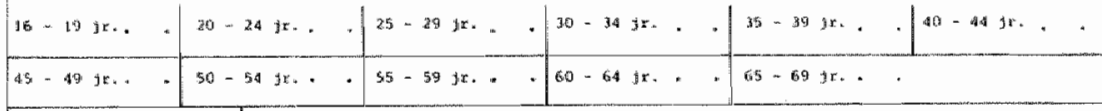

6

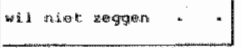

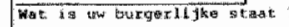

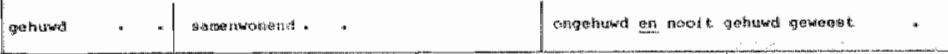

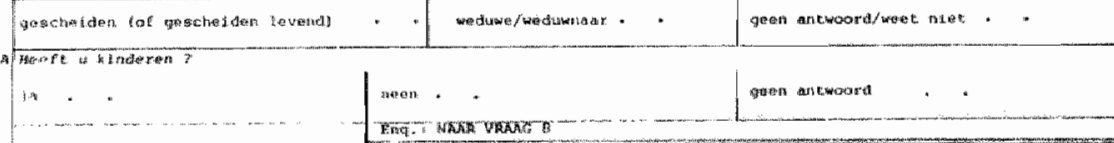

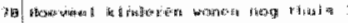

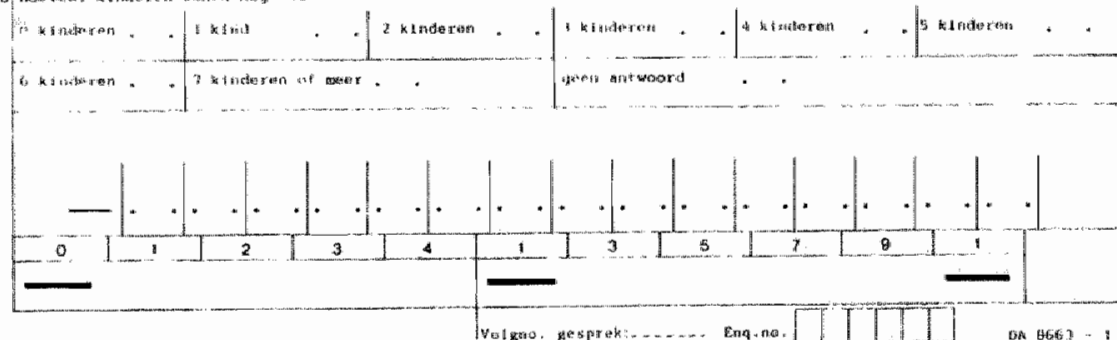




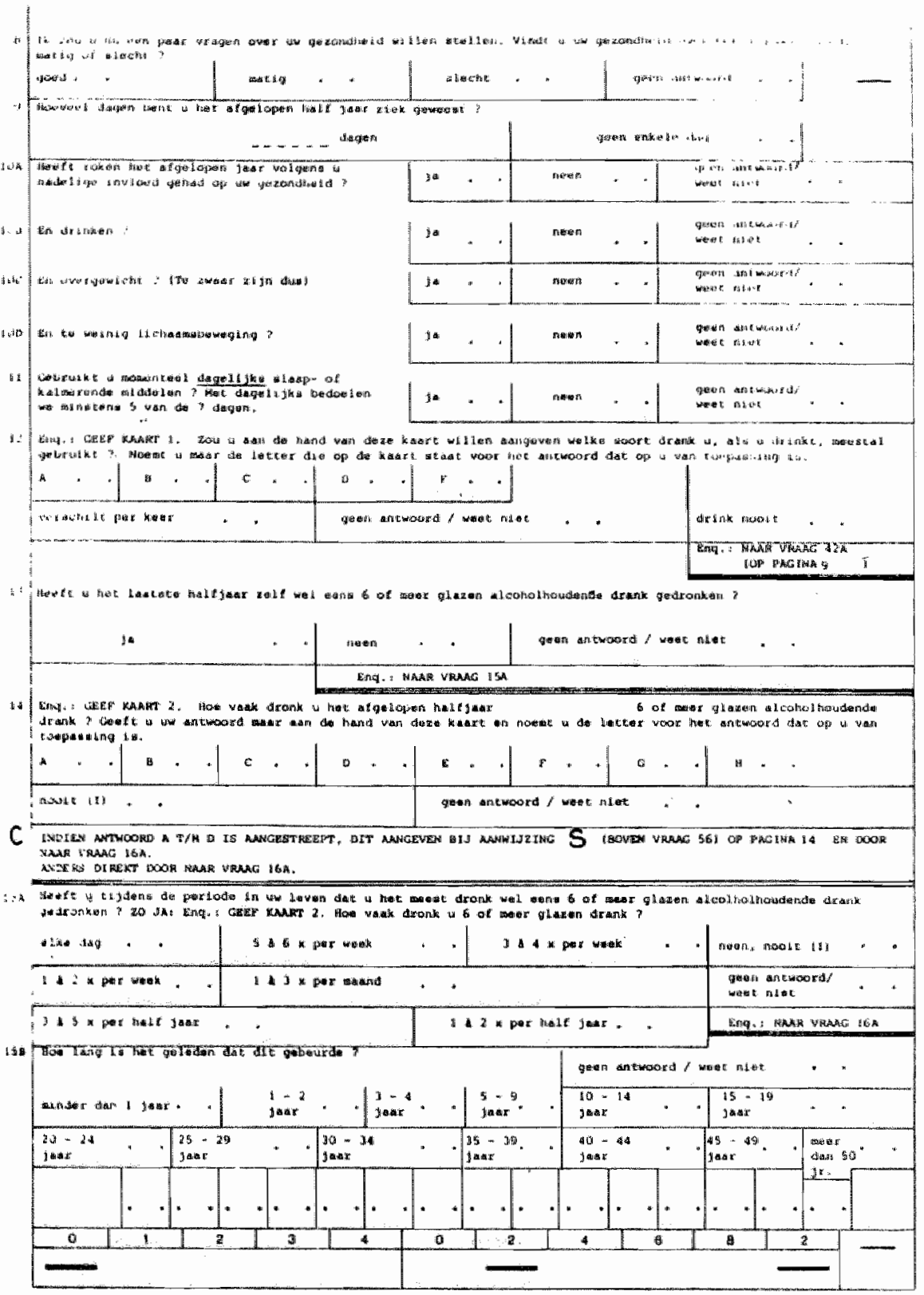

Dม $8665-$ 


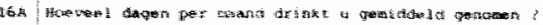

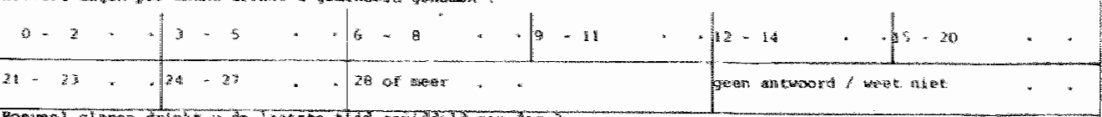

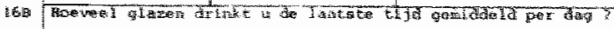

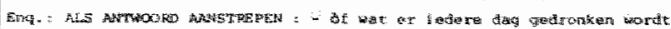

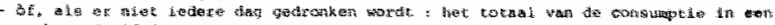

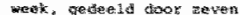

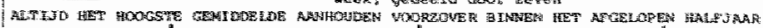

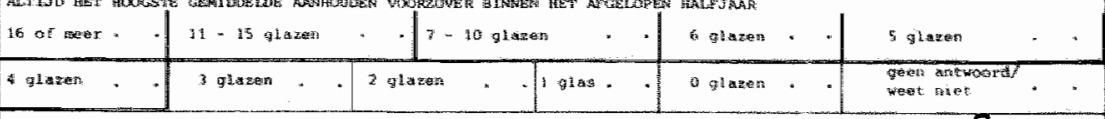

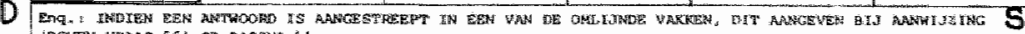

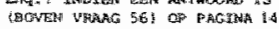

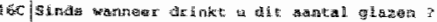

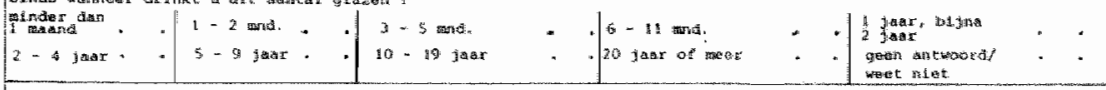

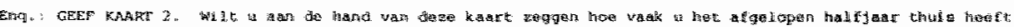

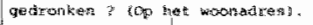

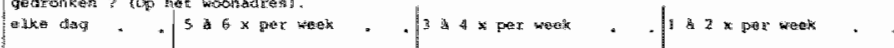

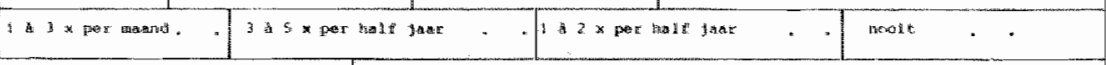

cheners antworord / bienter wiet

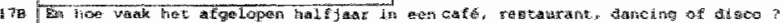

wike diag a

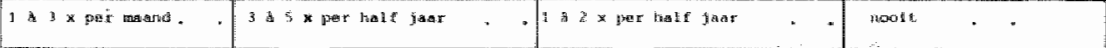

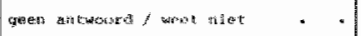

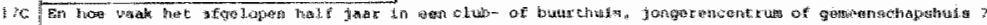

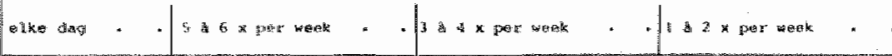

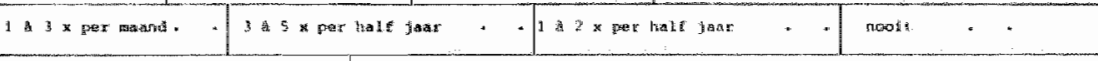

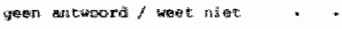

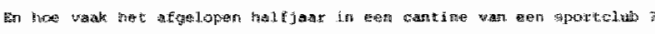

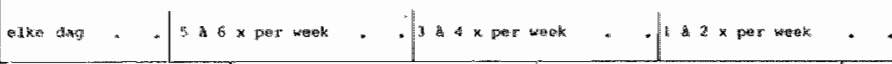

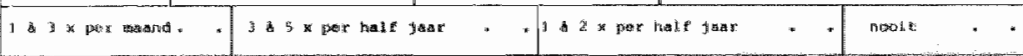

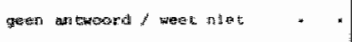

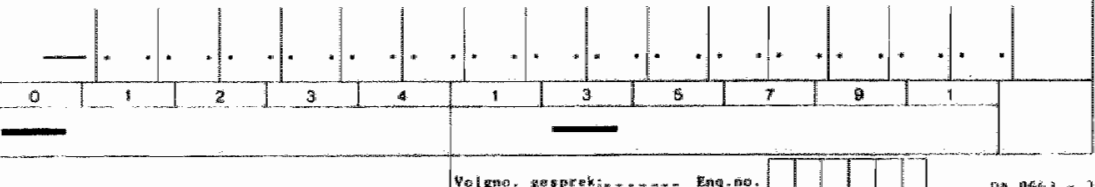

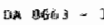




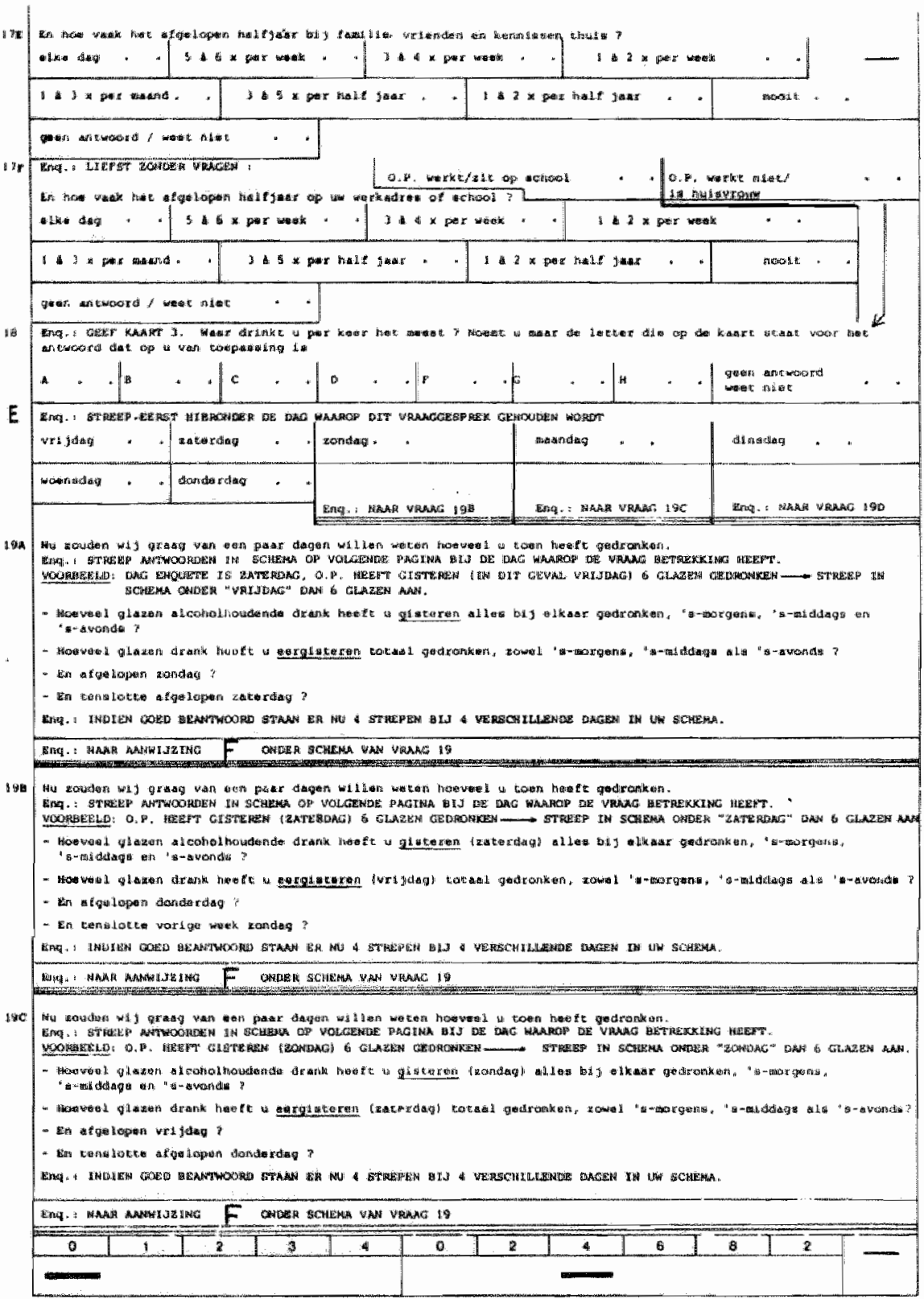




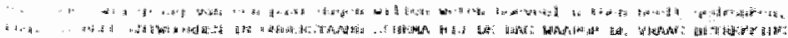

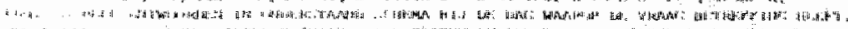

Ma

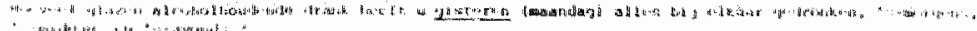

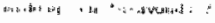

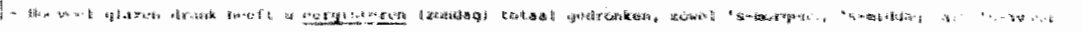

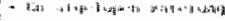

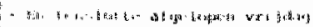

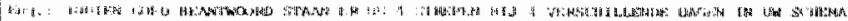

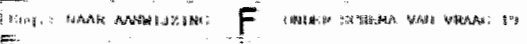

E:

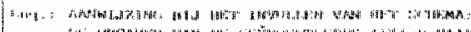

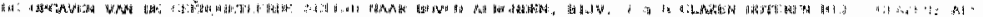

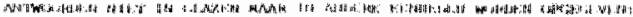

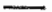

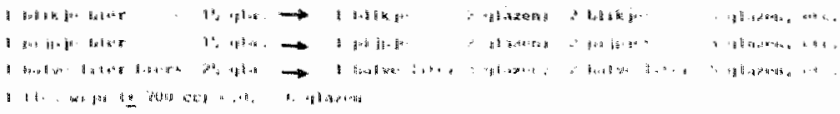

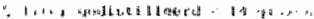

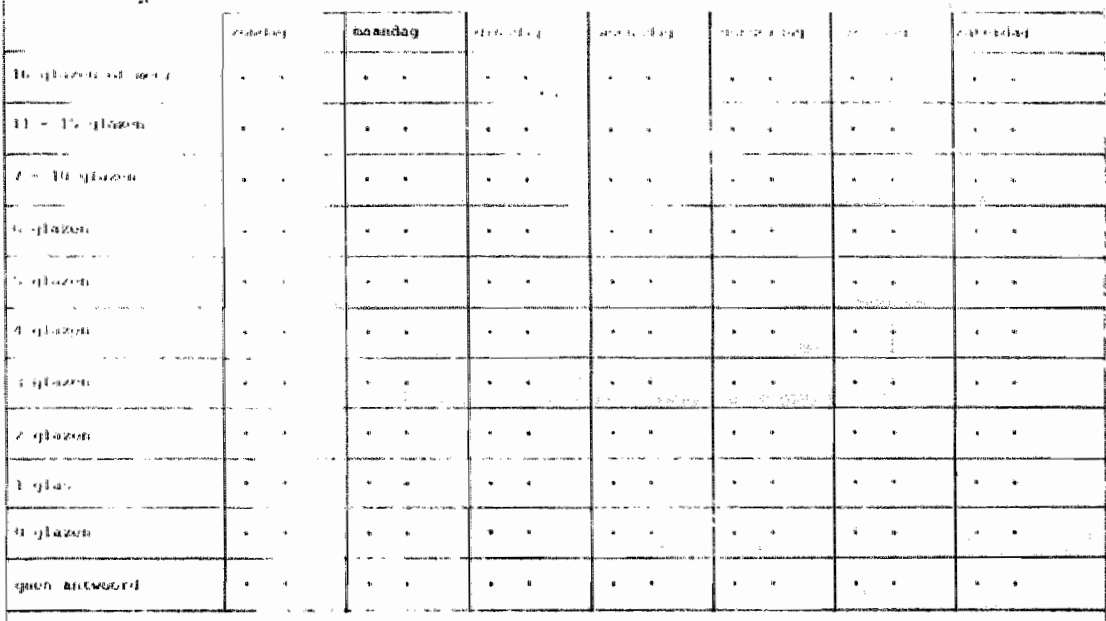

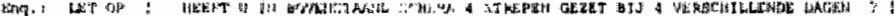

F

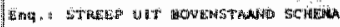

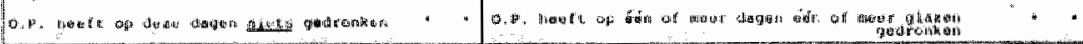

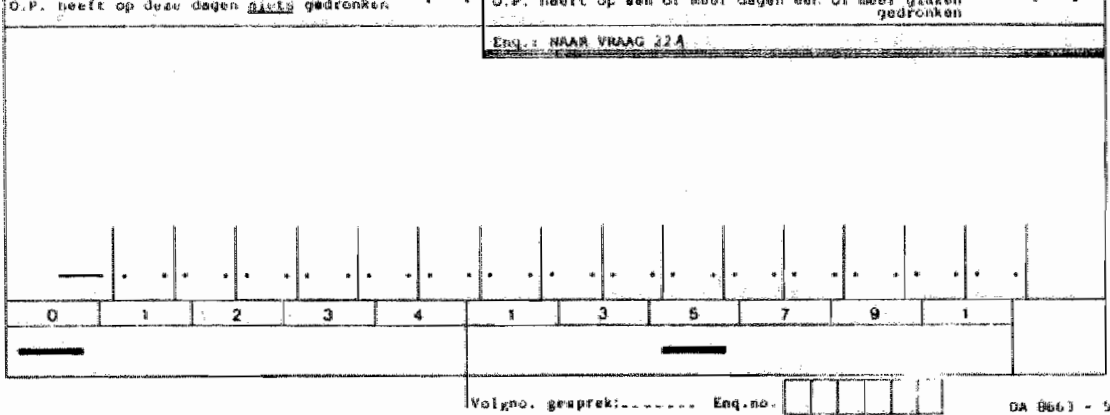




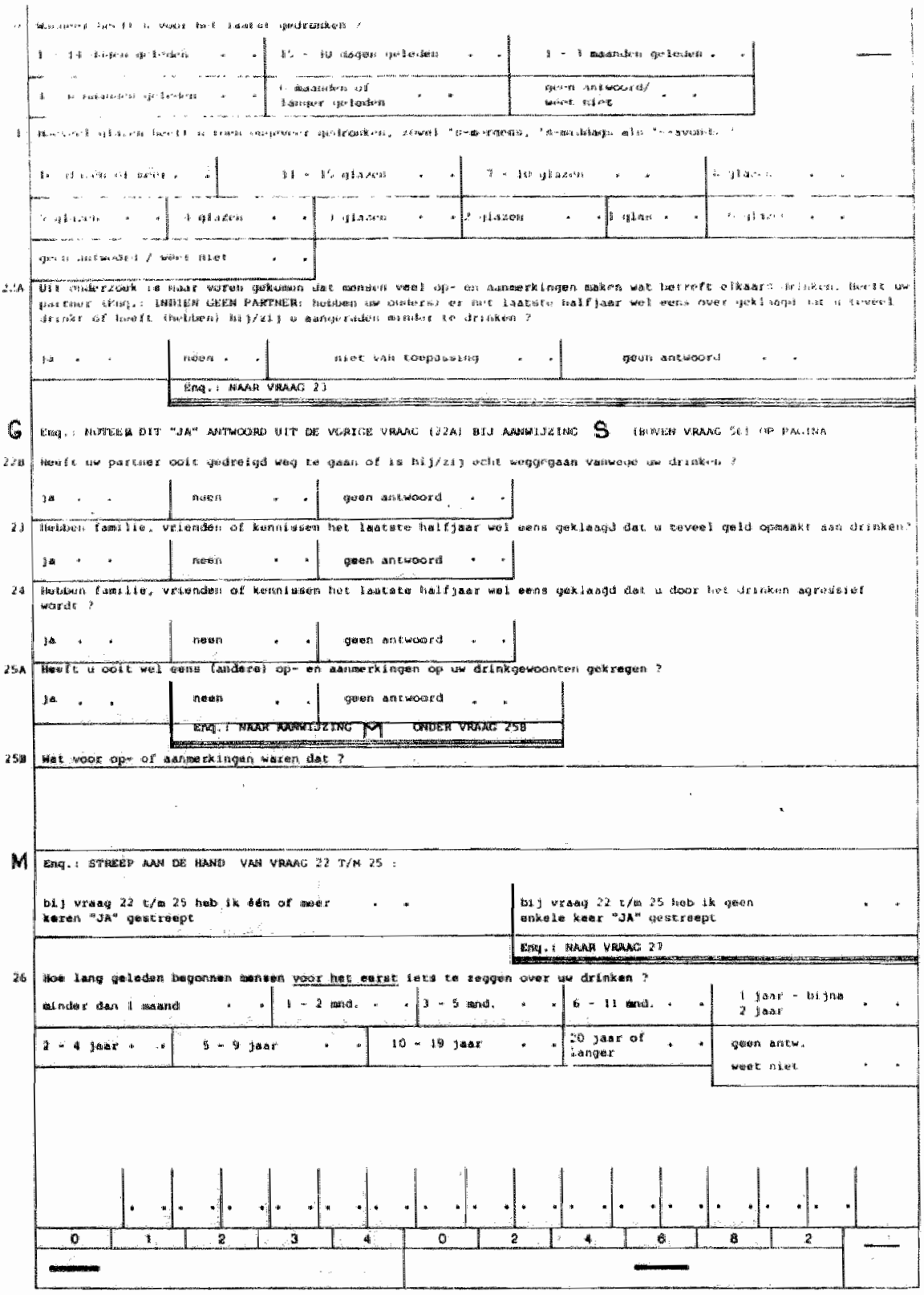

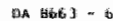




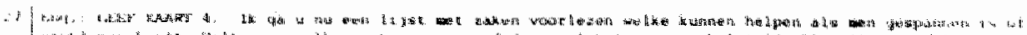

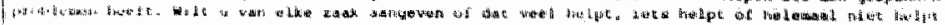

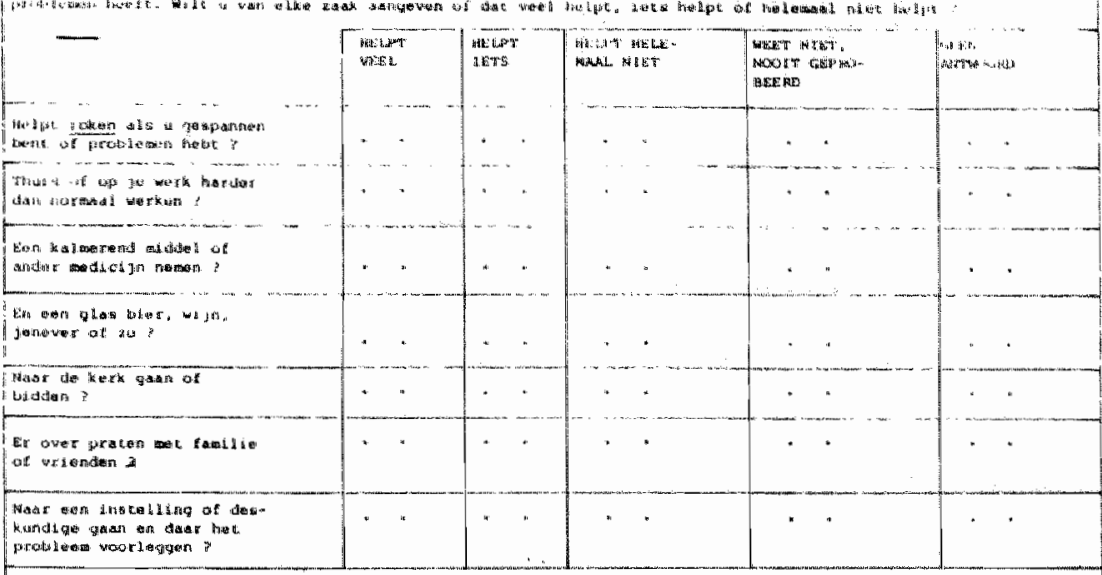

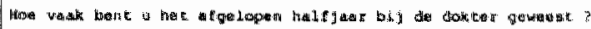

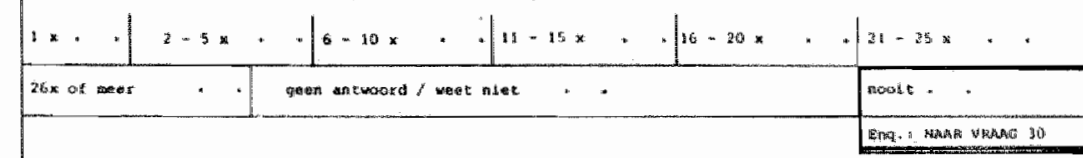

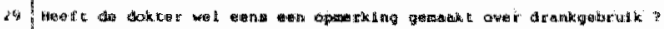

A

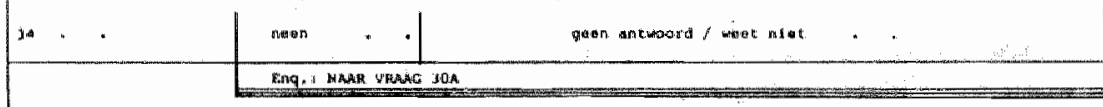

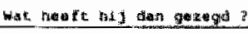

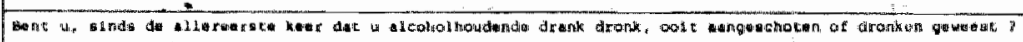

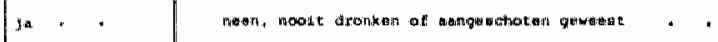

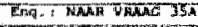

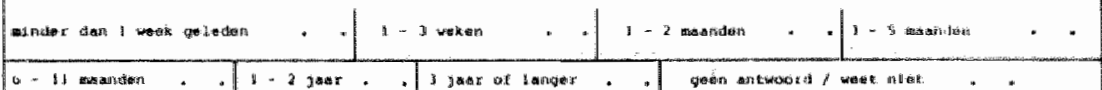

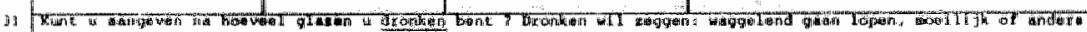

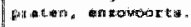

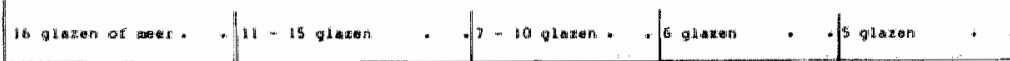

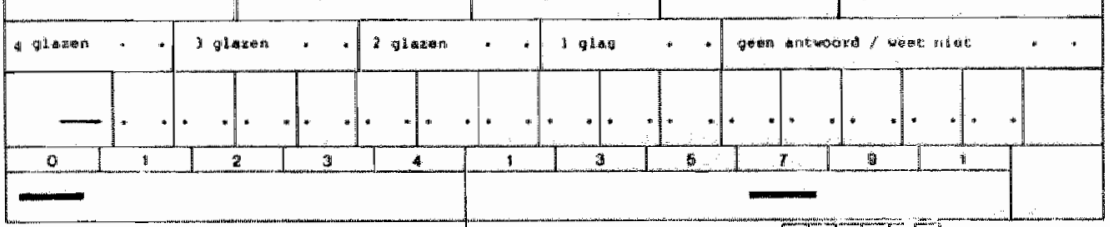




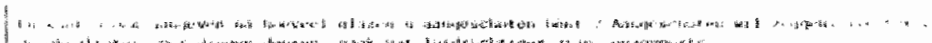

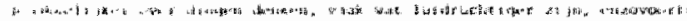

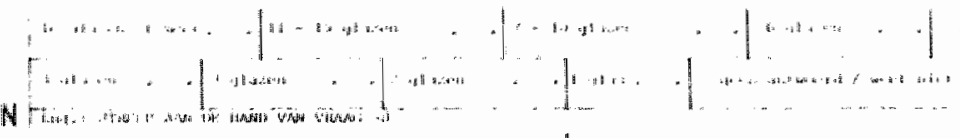

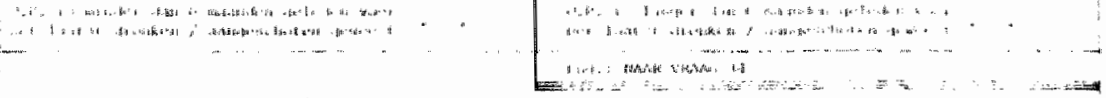

|

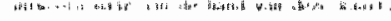

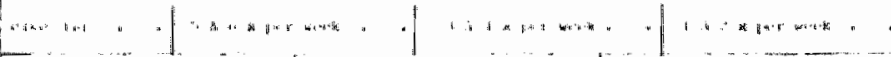

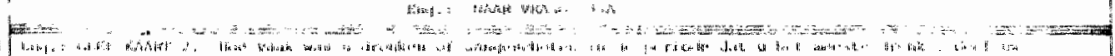
:

A

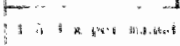

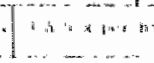

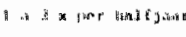

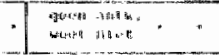

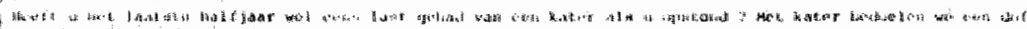

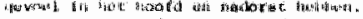

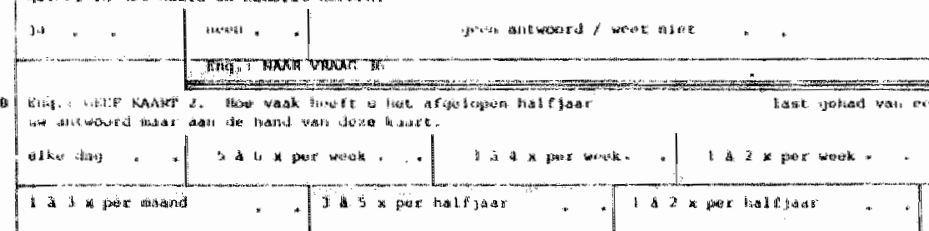

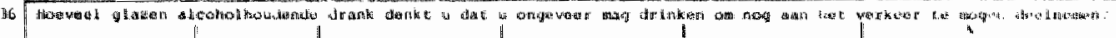

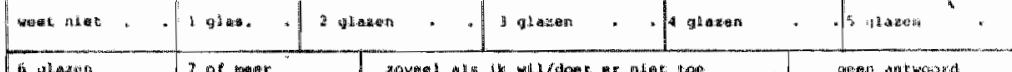

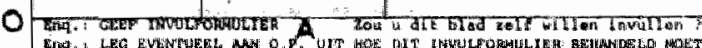

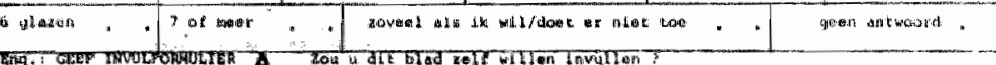

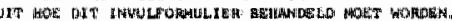

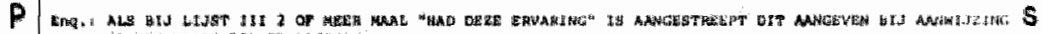

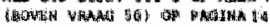

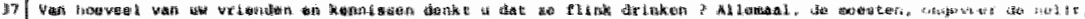

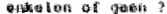

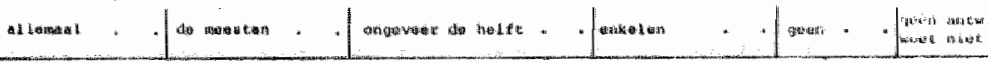

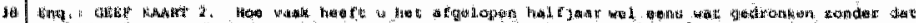

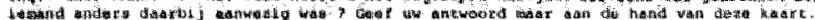

4.

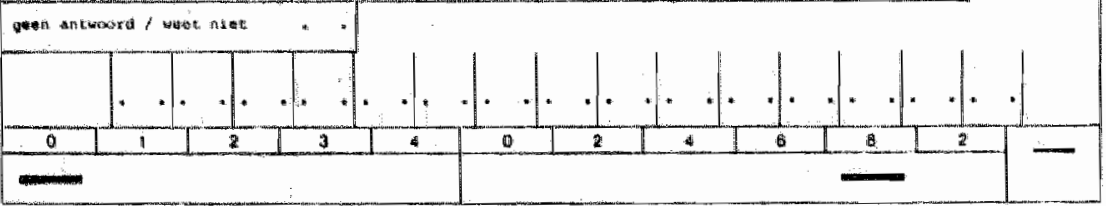




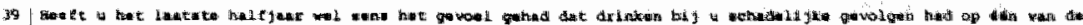

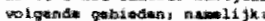

\begin{tabular}{|c|c|c|c|}
\hline & In & 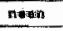 & gew antin. \\
\hline 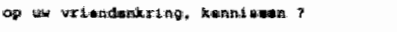 & . & . & $\cdot$ \\
\hline 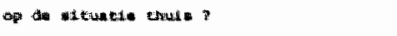 & . . & . & - \\
\hline 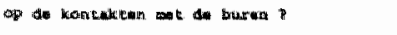 & . & 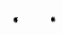 & $\cdot$ \\
\hline 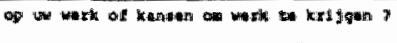 & " & 4 & $\cdot \quad 4$ \\
\hline
\end{tabular}

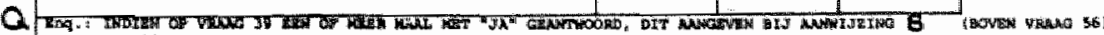
on pugan 14

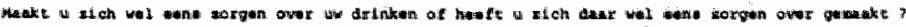

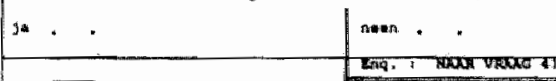

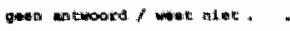

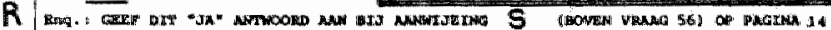

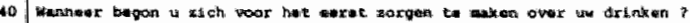

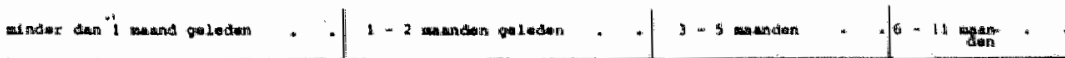

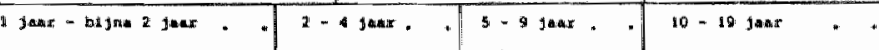

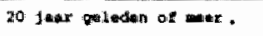

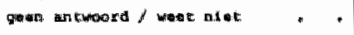

Jin.. nempi. .

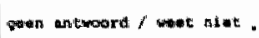

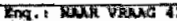

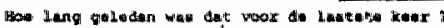

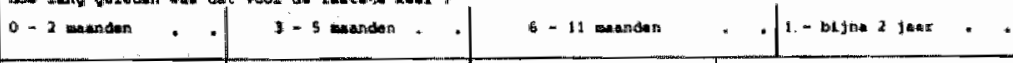

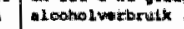

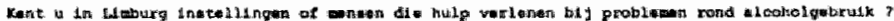

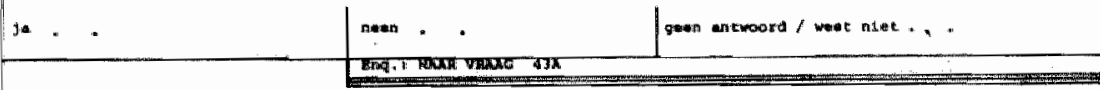

Wake linatelukmogn o whe kent on

20 Jewer of woer * " 


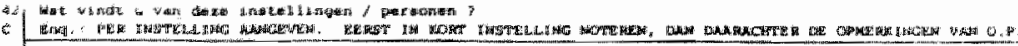

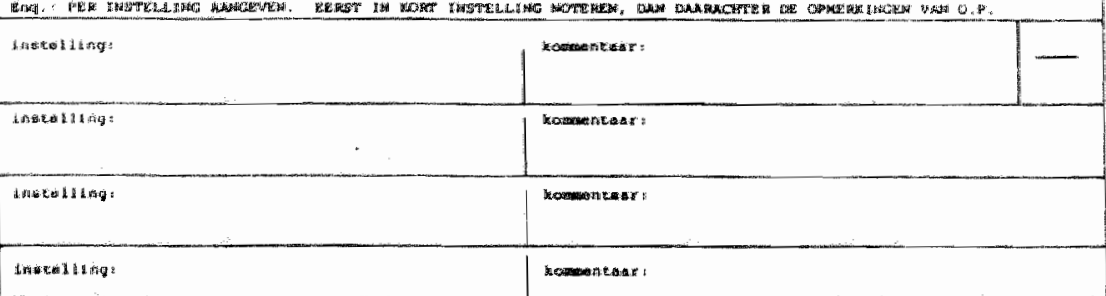

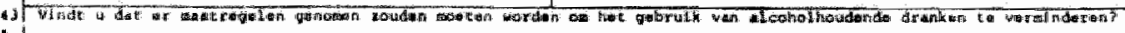
*

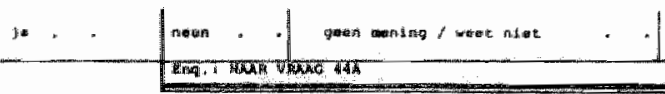

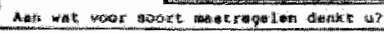

.

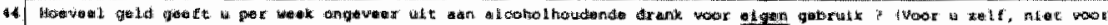

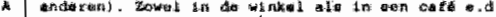

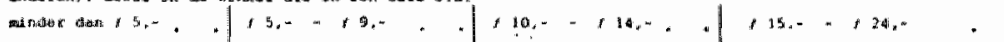

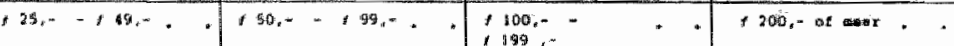

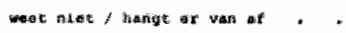

पean antwatat *

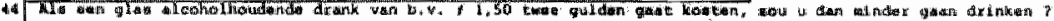

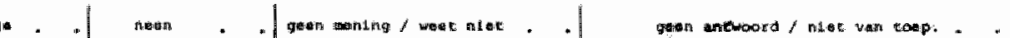

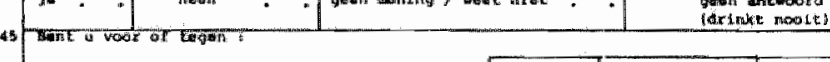

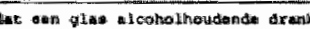

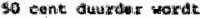

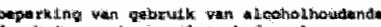

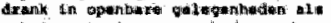

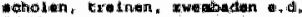

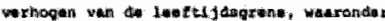

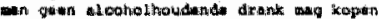

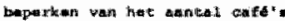

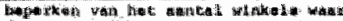

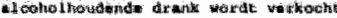

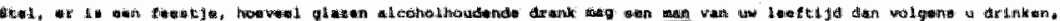

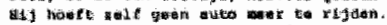

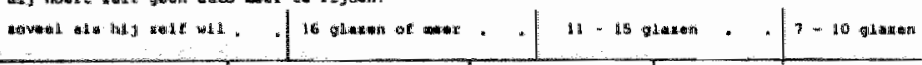

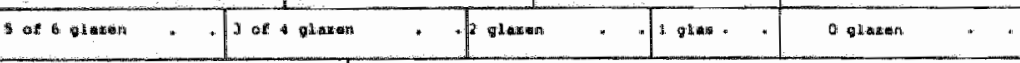

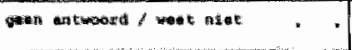

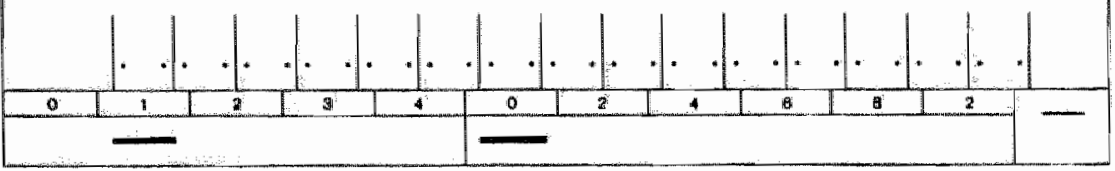

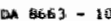


46

政

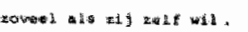

5

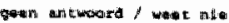

7

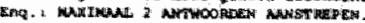

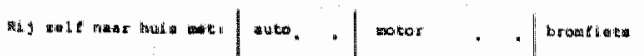

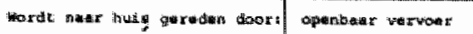

andere

Lopia wew hisit.

(3)

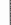

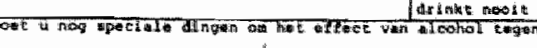

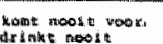

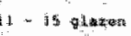

"

10 glaxen

$-100$

10 แask

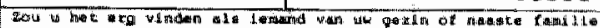

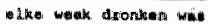

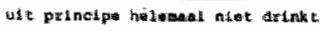

49

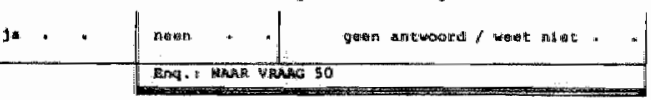

4

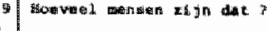

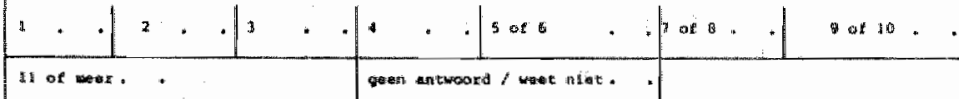

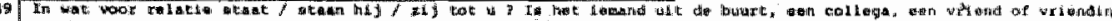

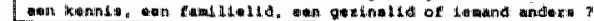

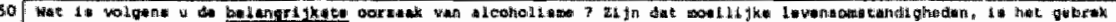

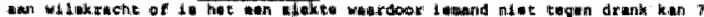

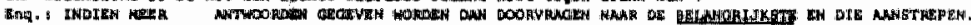

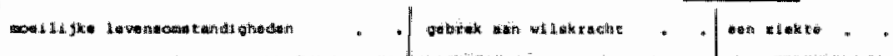

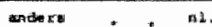

\begin{tabular}{|c|c|}
\hline 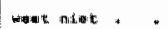 & 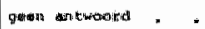 \\
\hline
\end{tabular}

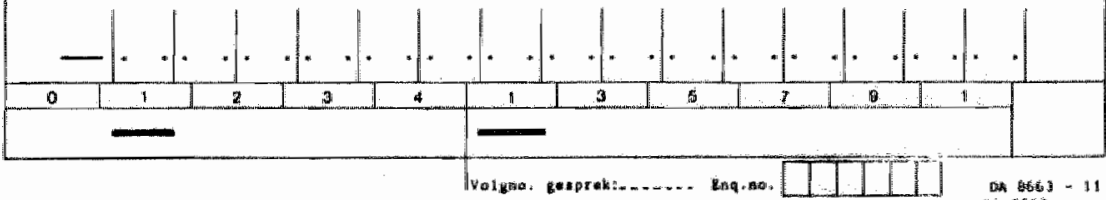




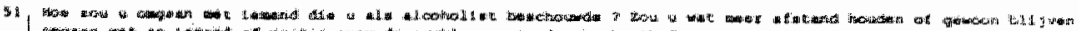

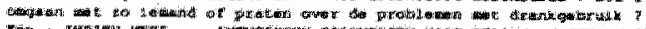

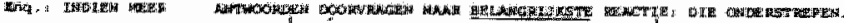

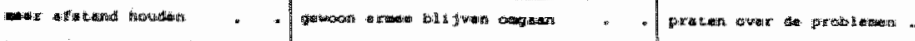

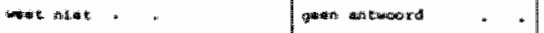

ir

\begin{tabular}{|c|c|c|c|c|c|}
\hline & 13 & 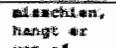 & Wwation & nat: & $\begin{array}{l}\text { gatenik } \\
\text { Antew. }\end{array}$ \\
\hline 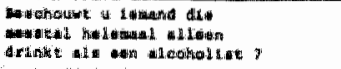 & . & , & " & • & \\
\hline 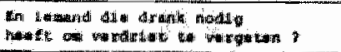 & " & - & ". & . & . \\
\hline 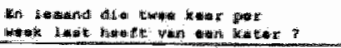 & • & , & . & • &. \\
\hline 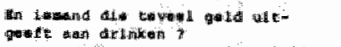 & , & • & $=$ & • & \\
\hline 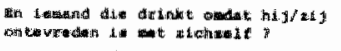 & & $\therefore$ & * & * & \\
\hline 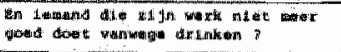 & & . & $*$ & $"$ & . \\
\hline 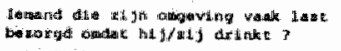 & • & . & . & $:$ & \\
\hline 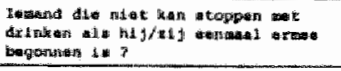 & & . & $"$ & * & \\
\hline 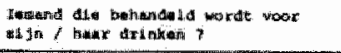 & & . & . & " & \\
\hline 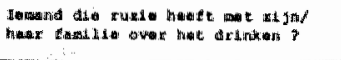 & & . & " & " & \\
\hline 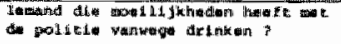 & $\cdot$ & $"$ & " & $\varpi$ & \\
\hline
\end{tabular}

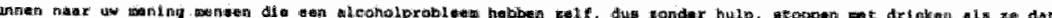

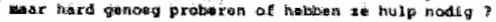

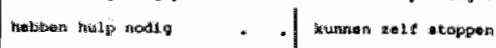

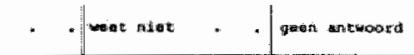

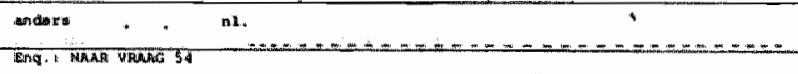

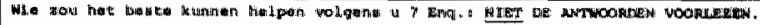

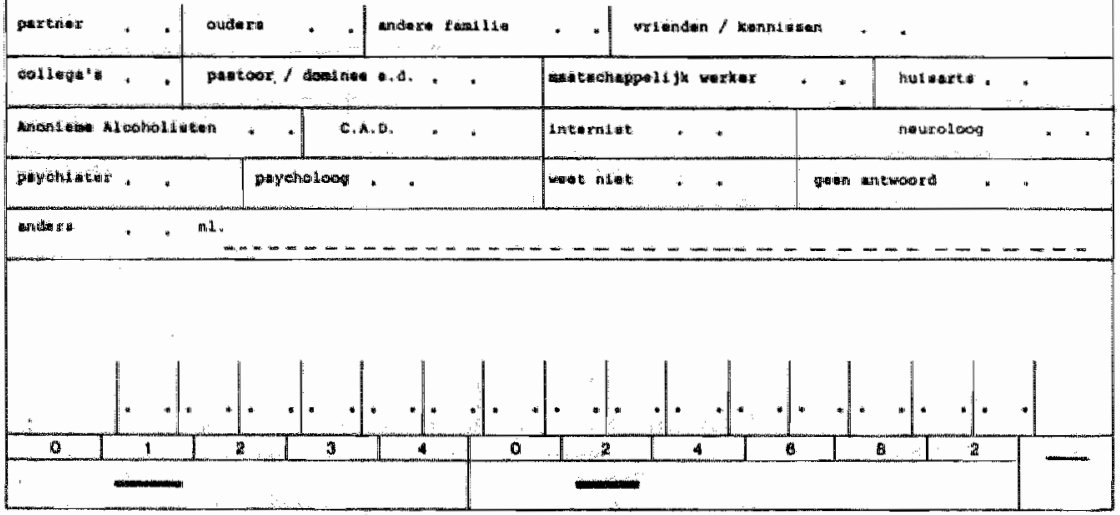




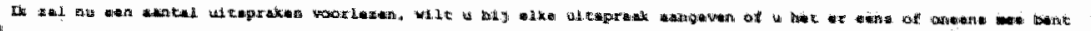

\begin{tabular}{|c|c|c|c|c|}
\hline & $\begin{array}{l}\text { wet } \\
\text { wents }\end{array}$ & 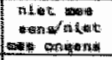 & 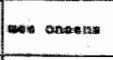 & tation. \\
\hline 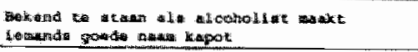 &.$\quad$. & $\cdot$ & * & 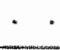 \\
\hline 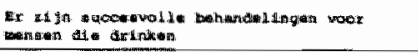 & - & - & - & n \\
\hline 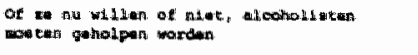 & $\cdot$ & : & 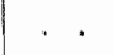 & * \\
\hline 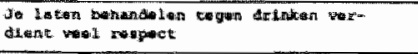 & $*$ & * & & $\cdot$ \\
\hline 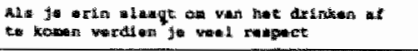 & - " &.$\quad *$ & - & $\cdot$ \\
\hline 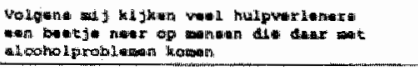 & * & $n$ & - & \\
\hline 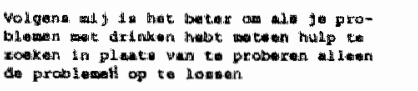 & * & $\cdot$ & $"$ & $*$ \\
\hline 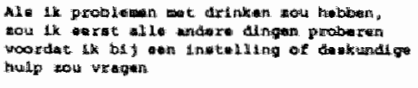 & $\cdots$ & ". & " & " \\
\hline 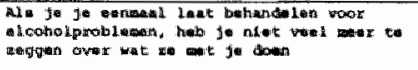 & $\cdot \quad *$ & 4. & $\cdot$ & $"$ \\
\hline 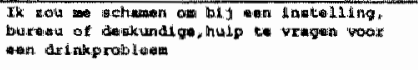 & . $\quad$ & - & $\cdot$ & $"$ \\
\hline 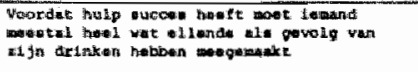 & 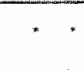 & $\cdot$ & $\cdot$ & $\cdot$ \\
\hline 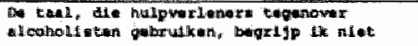 & & - & & " \\
\hline
\end{tabular}

Ema

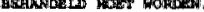

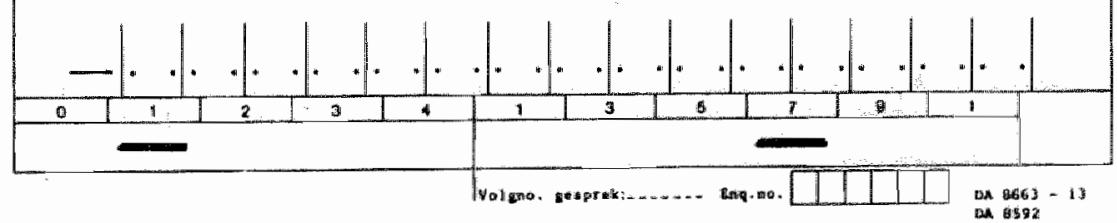




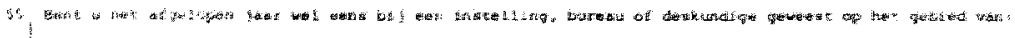

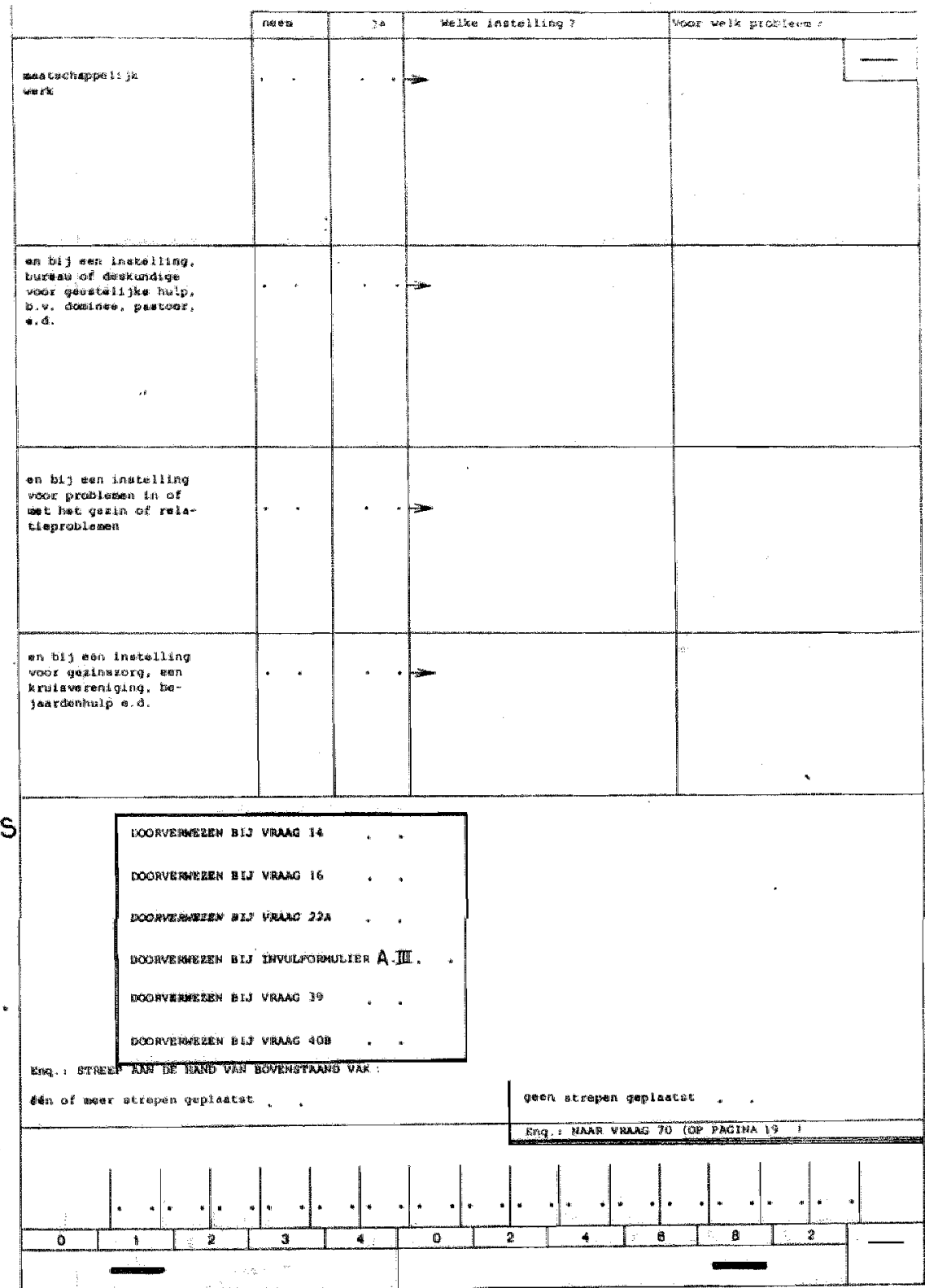

D.A. ST 


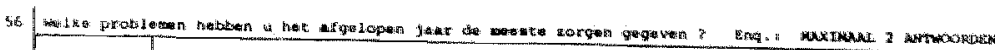

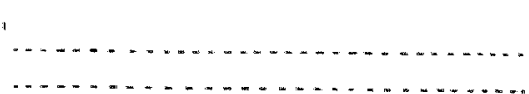

noen

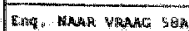

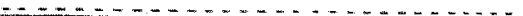

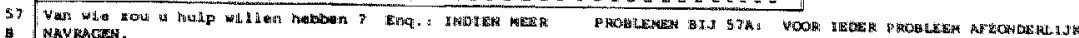
MANRACEA

Probleent

Probseats:

Provilee:

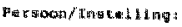

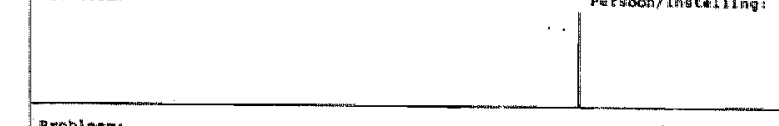

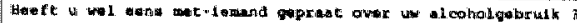

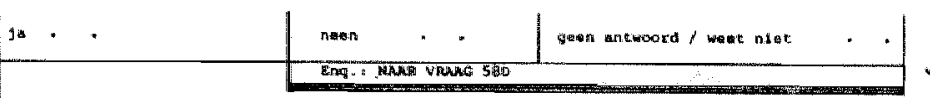

58

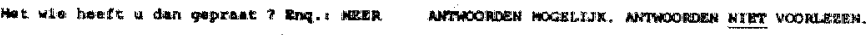

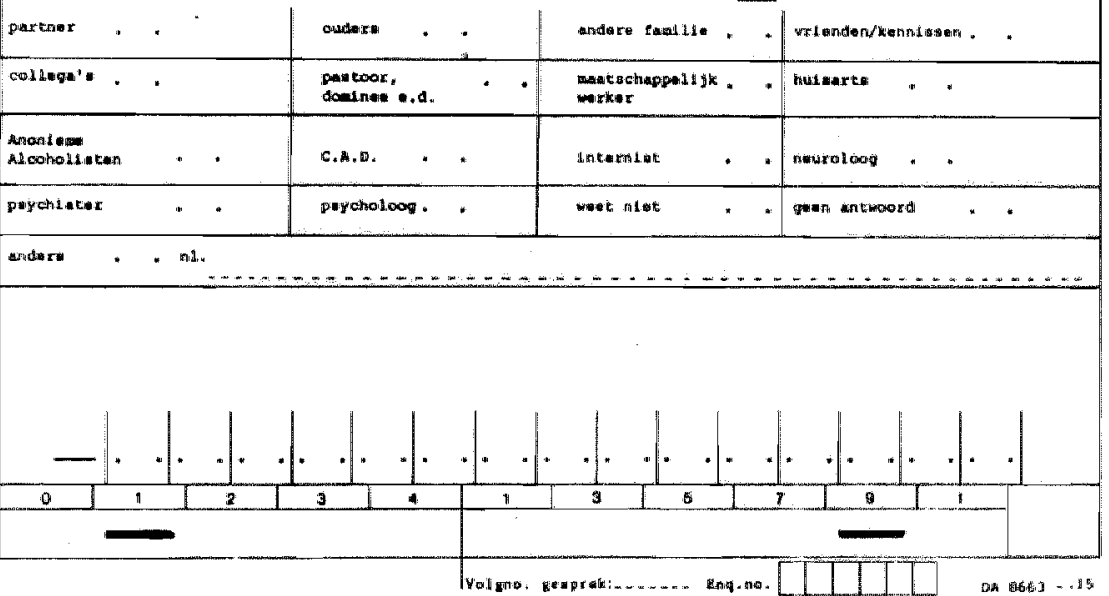




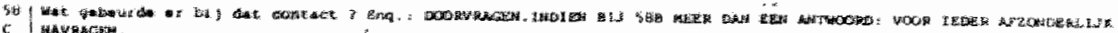
c. Havakikit
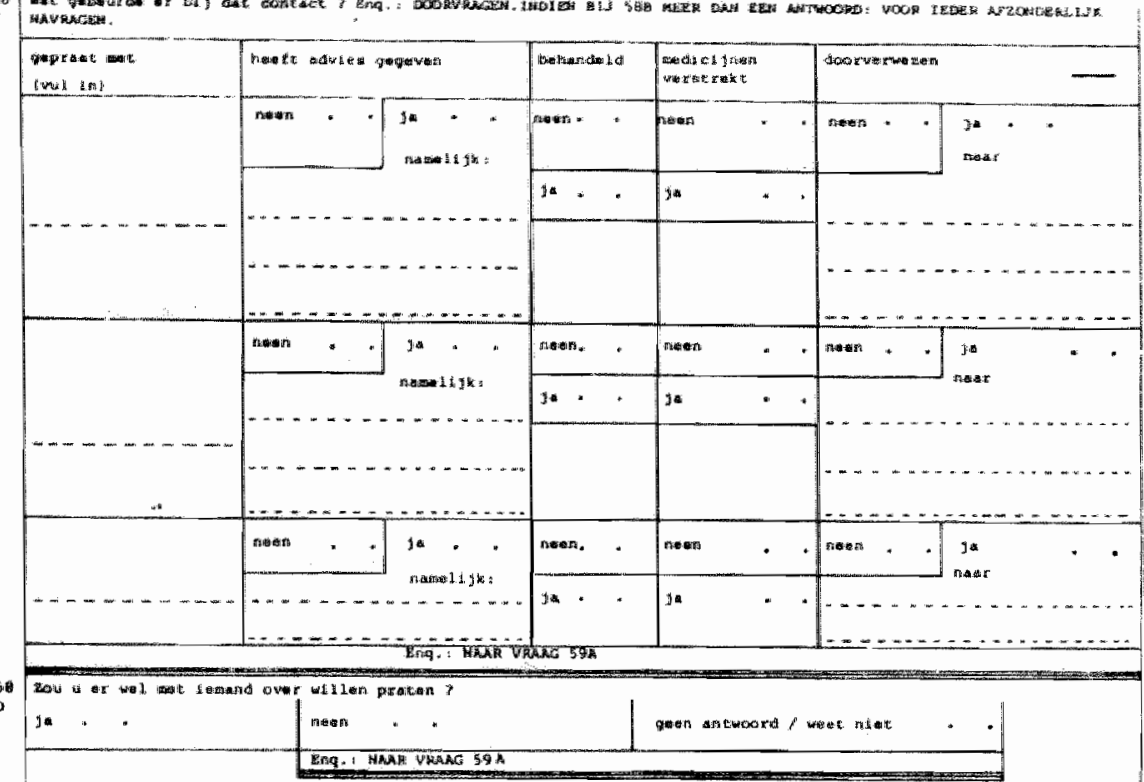

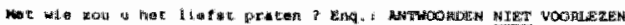

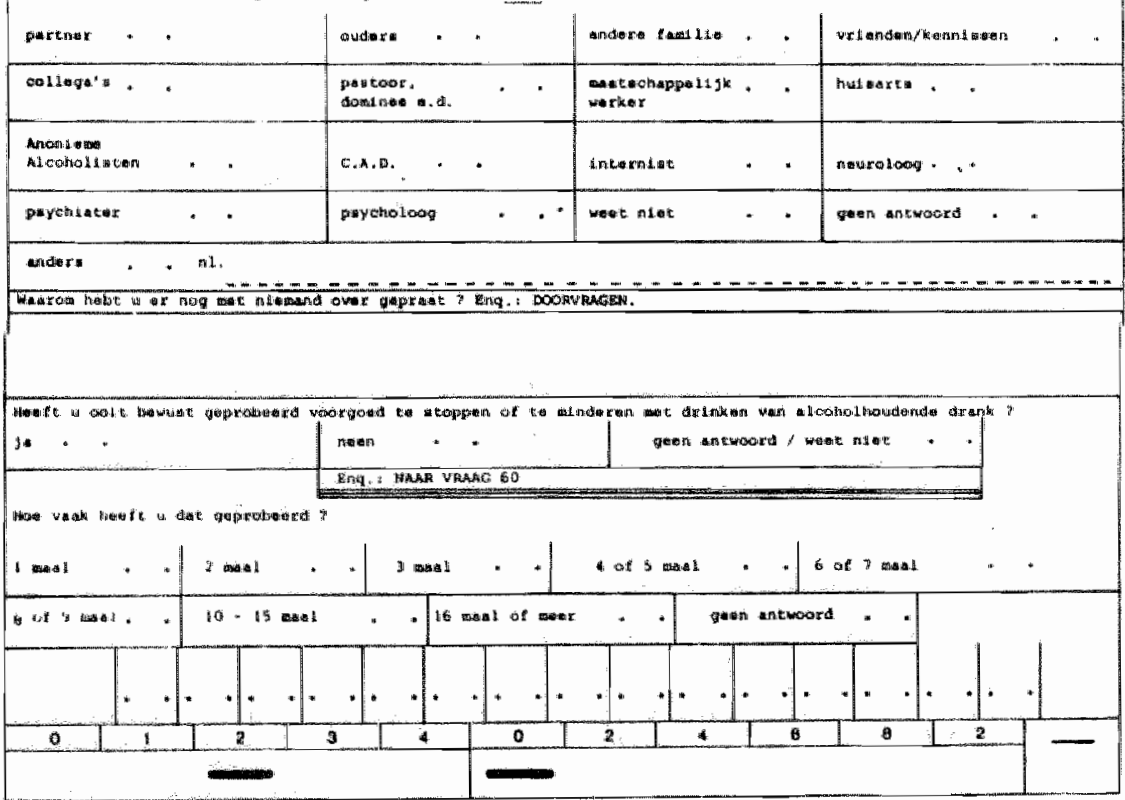




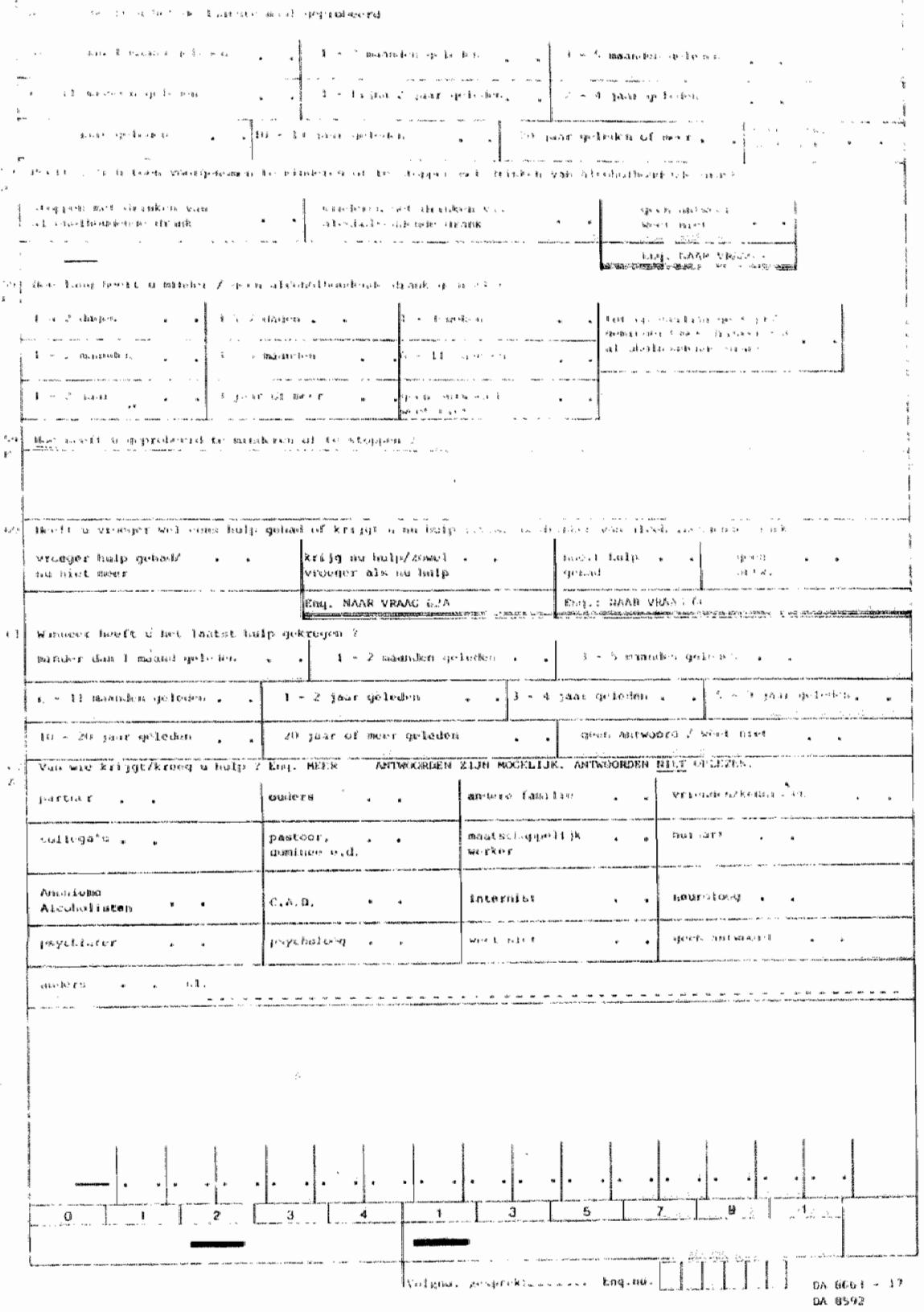




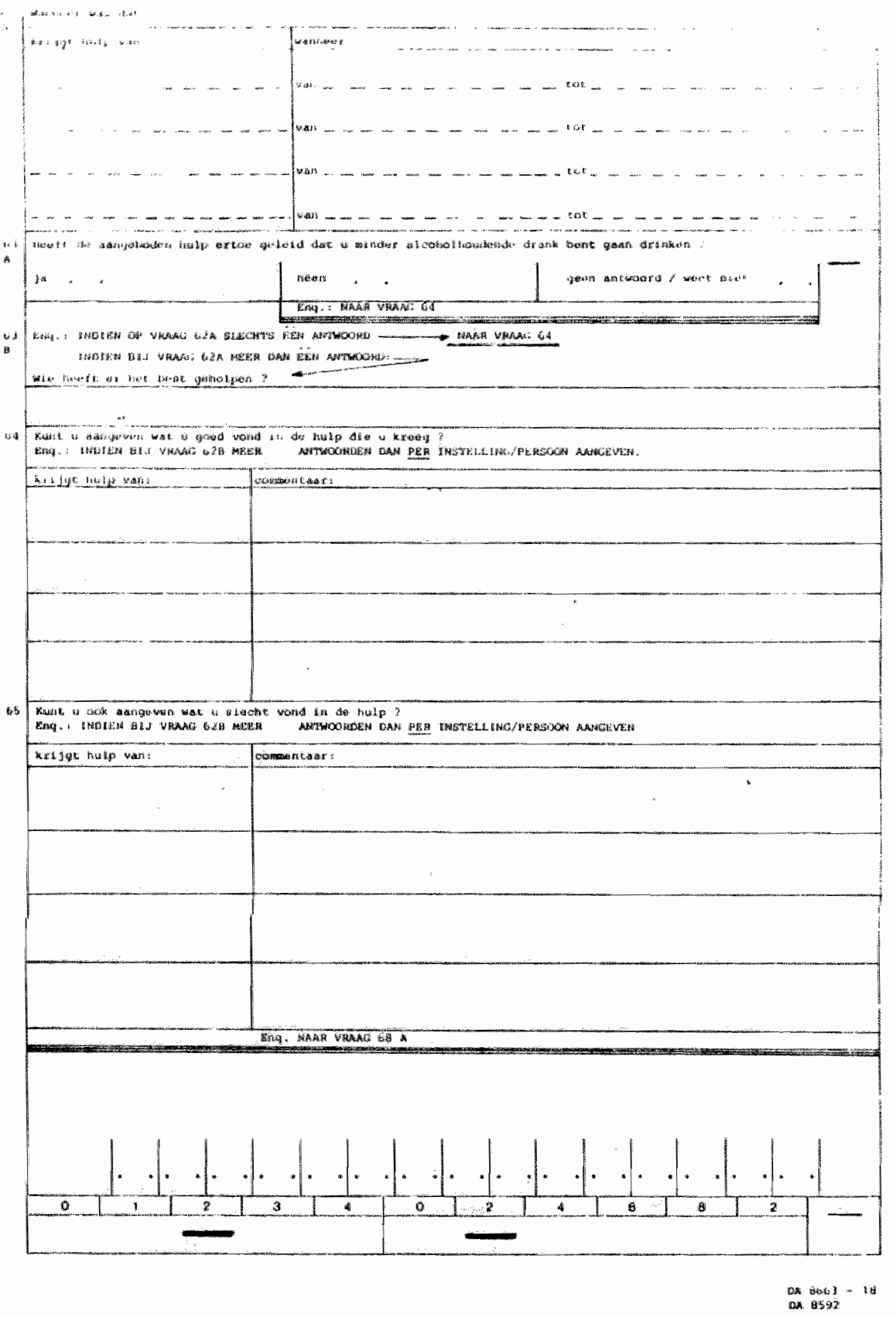




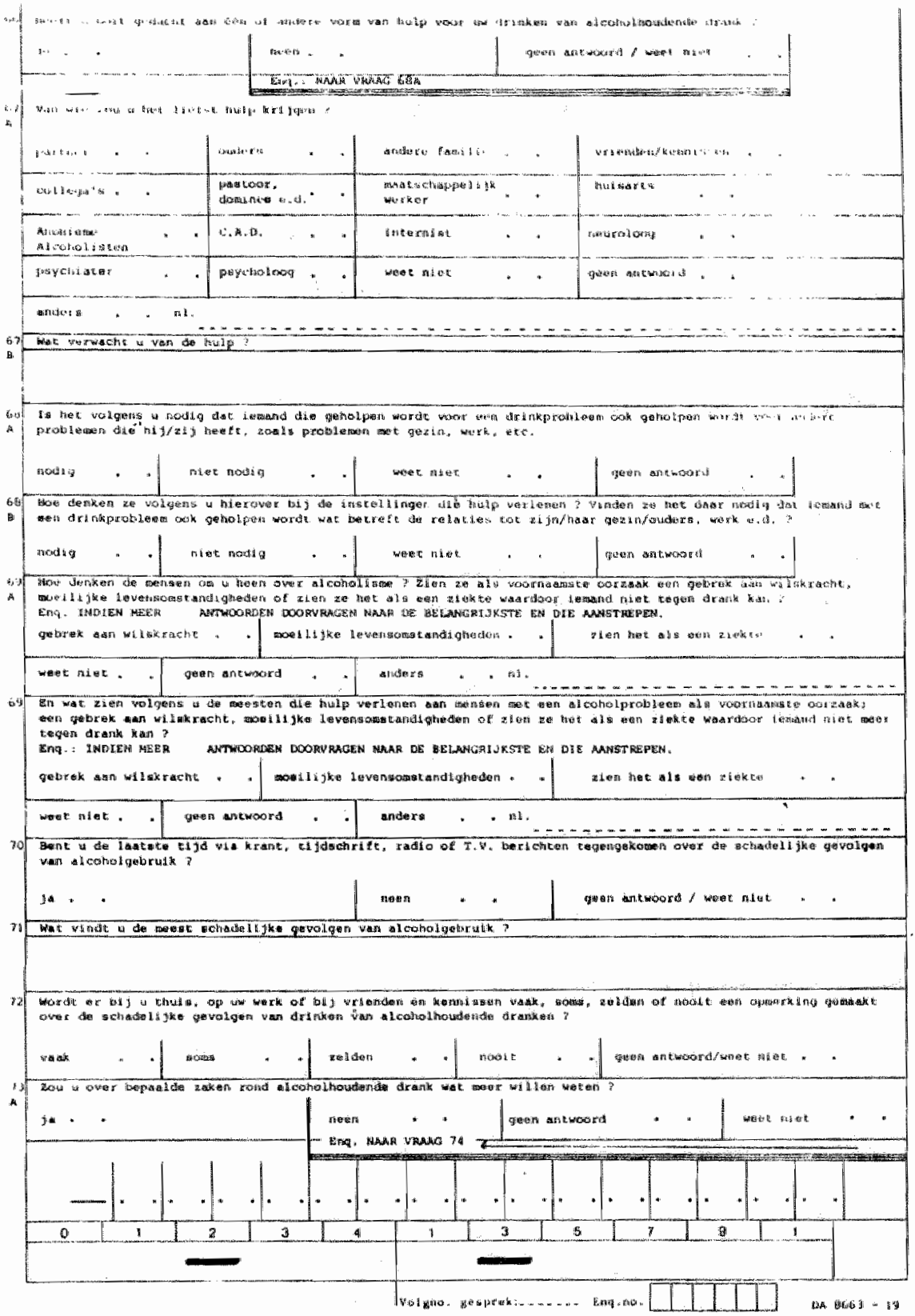




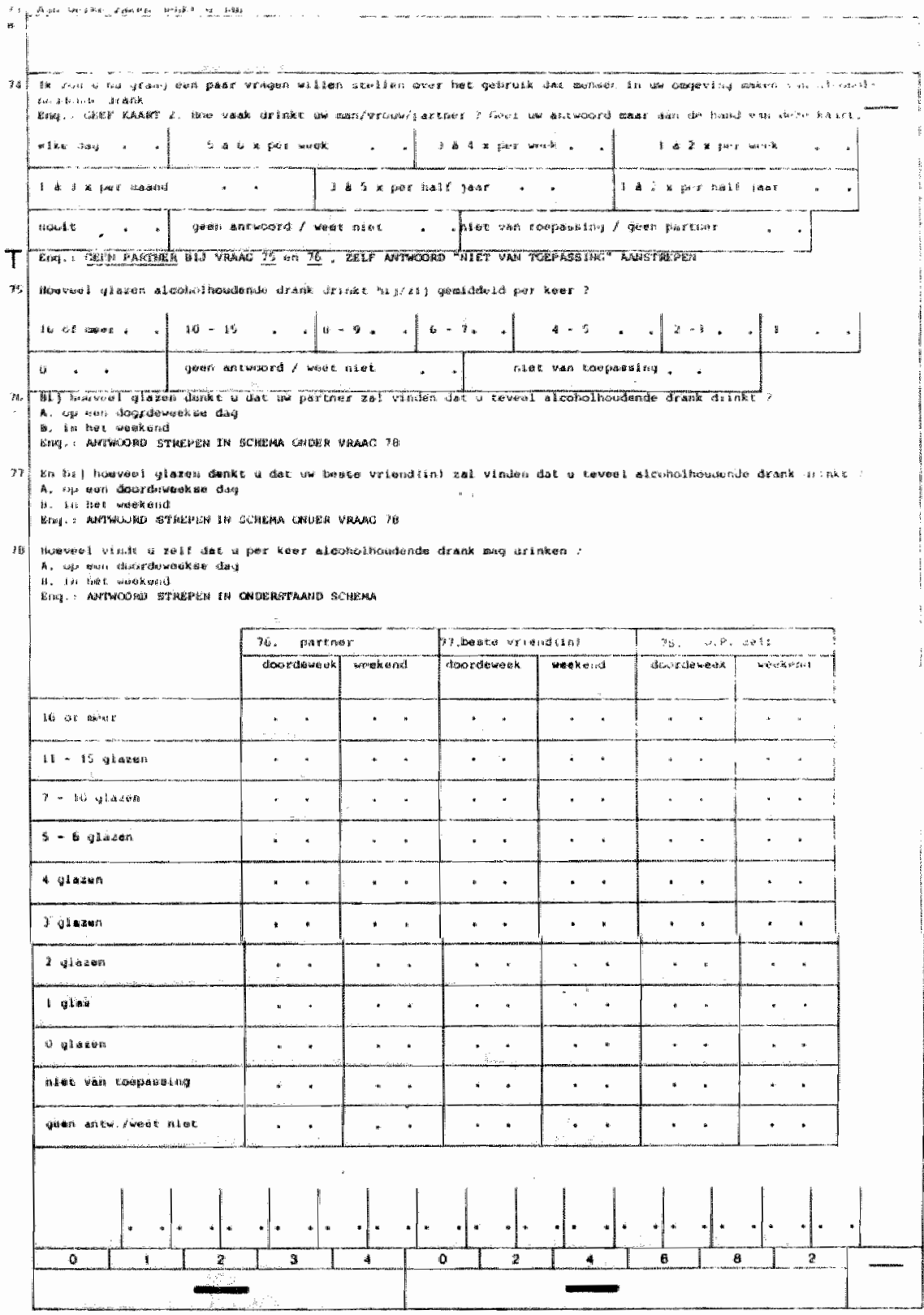

50.4 $864-26$ Wh 335 : 


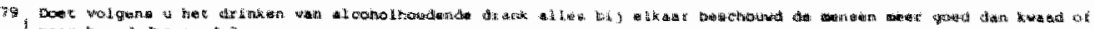

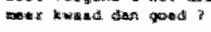

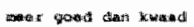

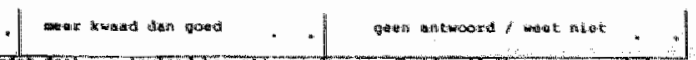

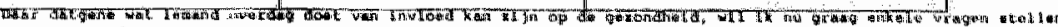

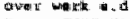

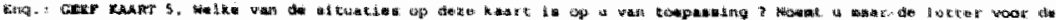

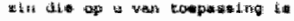

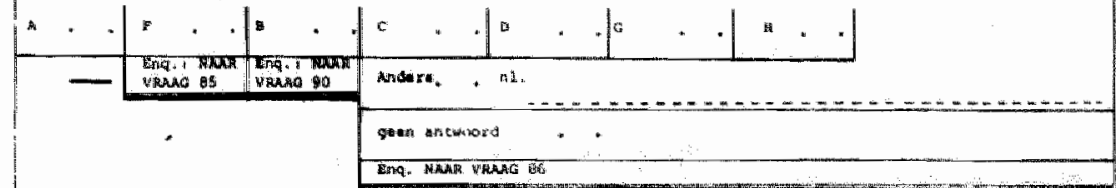

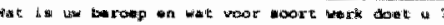

Beop:

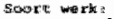

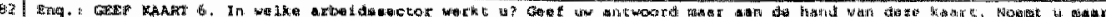

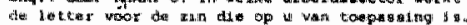

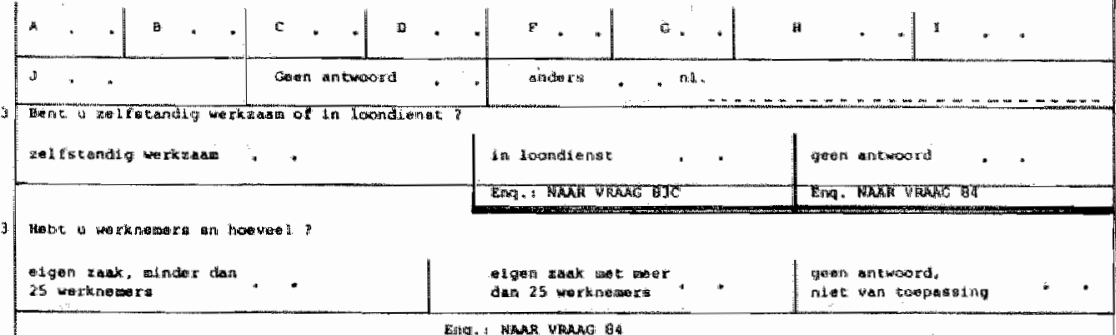

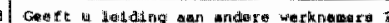

B.

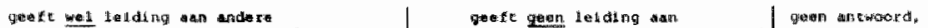
werkinera

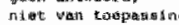

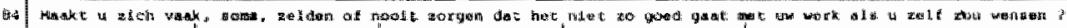

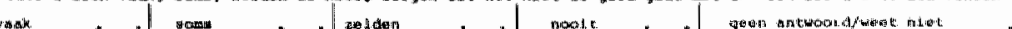

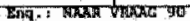

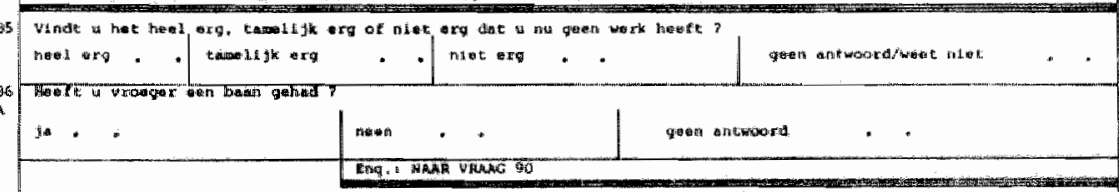

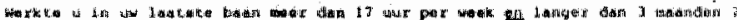

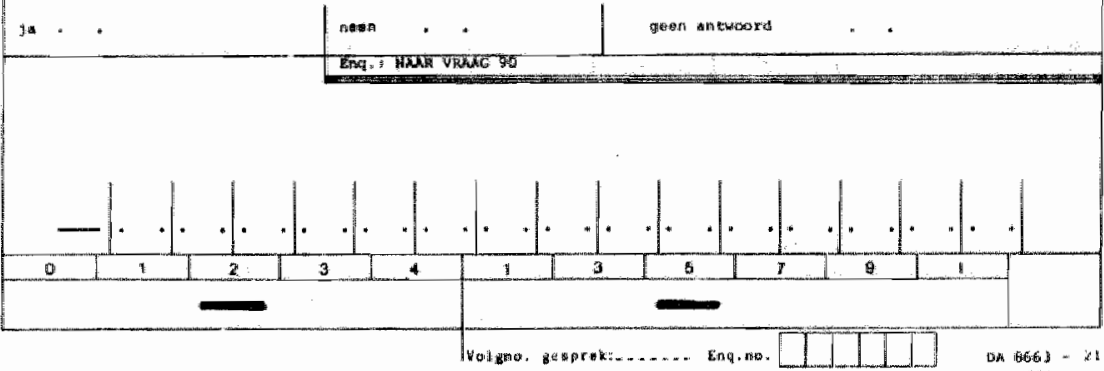




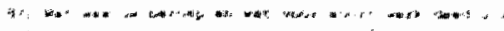

itim

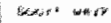

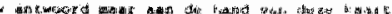

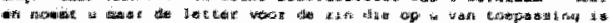

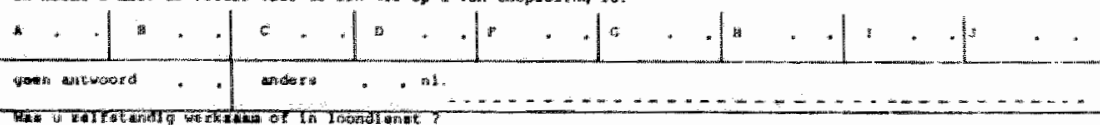

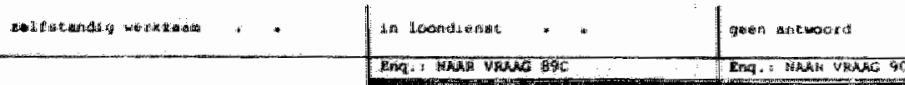

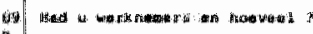

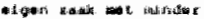

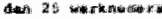

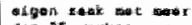

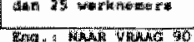

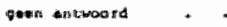

(ans:

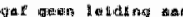

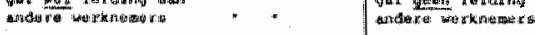

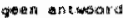

toto

peen an theorid,$*$

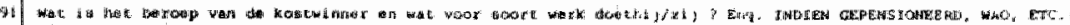

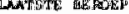

(1)

Siscent wert

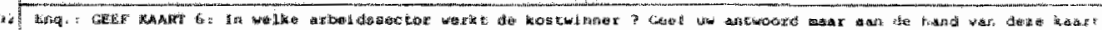

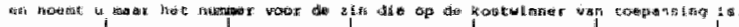

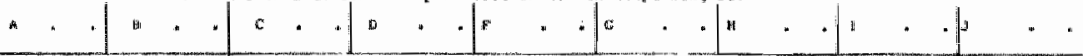

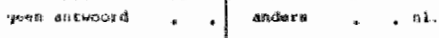

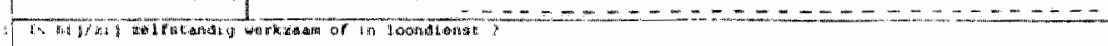

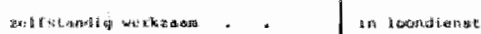
gon antugard

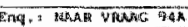

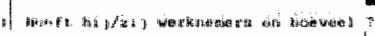

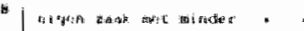

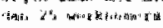

1

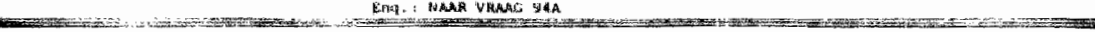

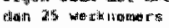

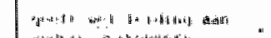

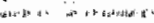

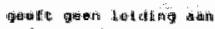

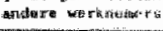

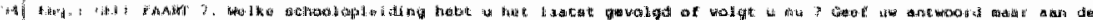

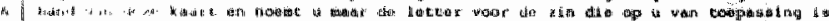

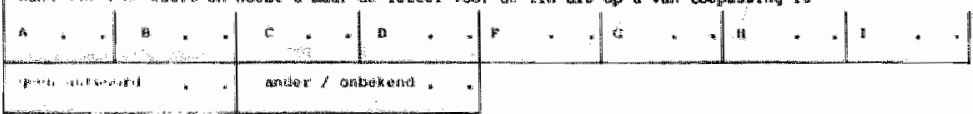

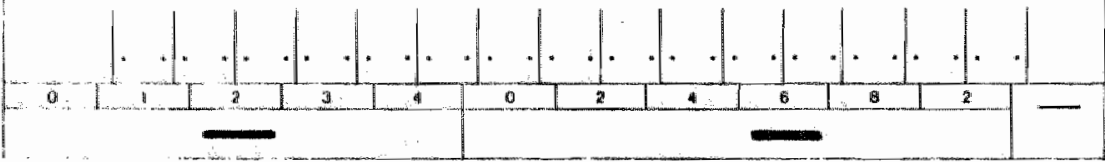

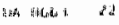




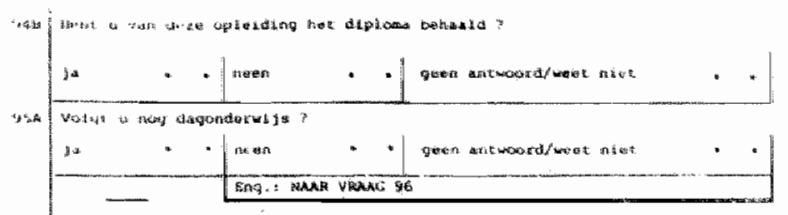

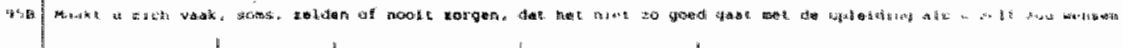

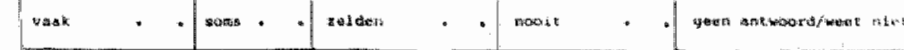

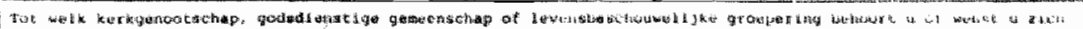

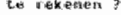

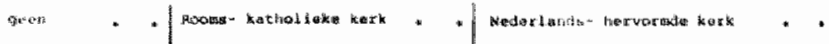

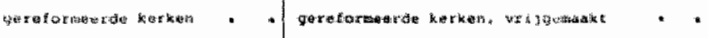

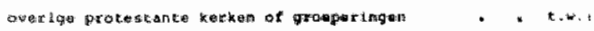

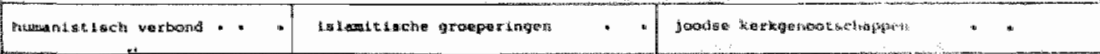

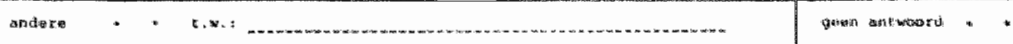

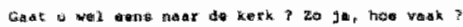

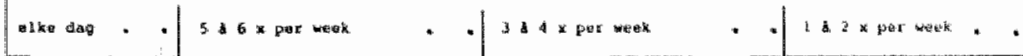

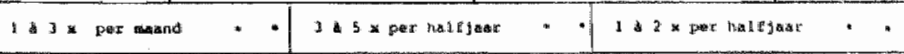

(wa jwos? sooit

gaten antworthere nielt

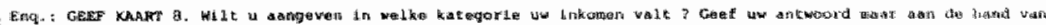

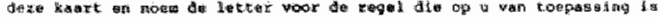

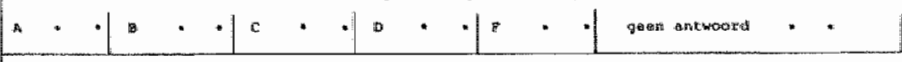

Wat vand 4 wal dite Anterwiew?

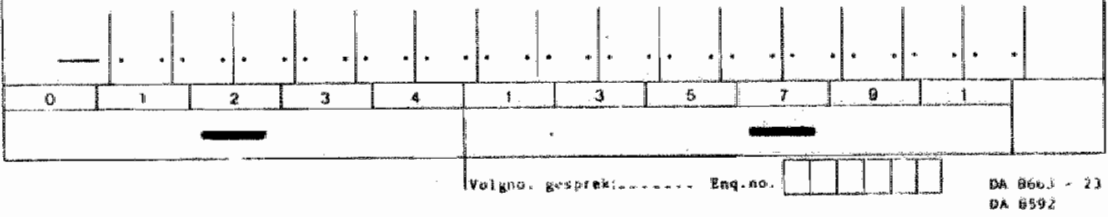




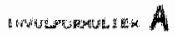

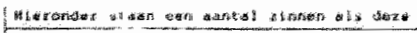

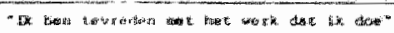

1.

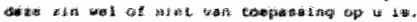

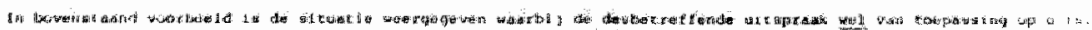
Ho

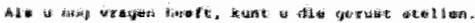

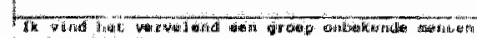

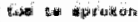

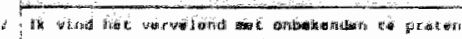

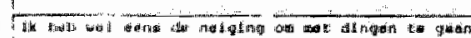
1000

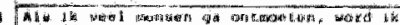

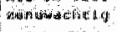

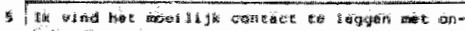
Heatianirith

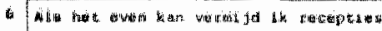

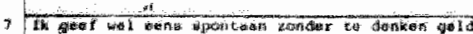

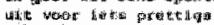

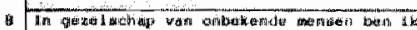

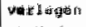

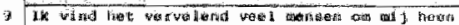
the thetelat

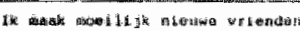

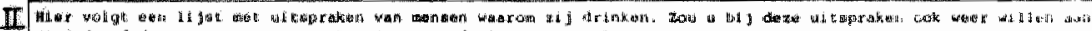

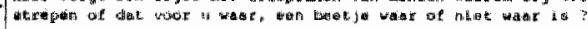

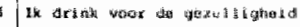

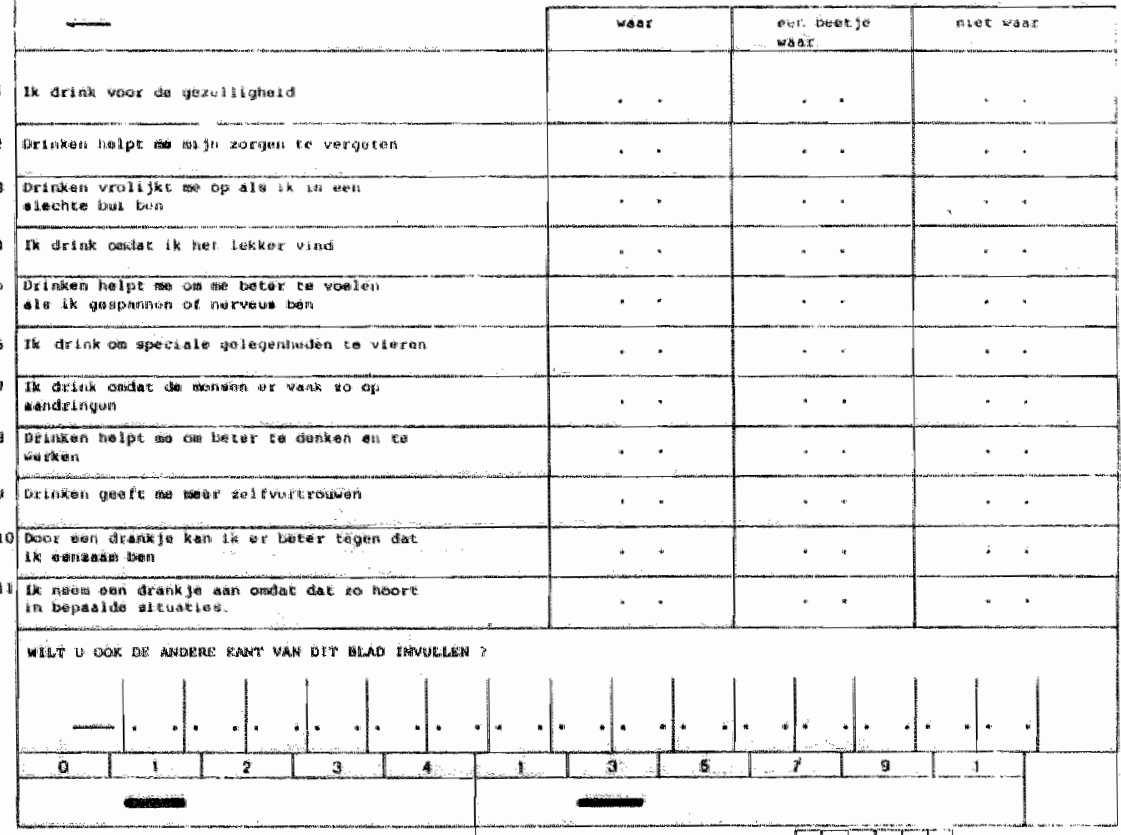




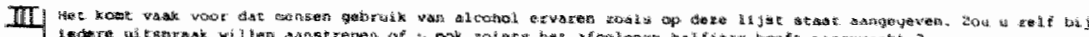

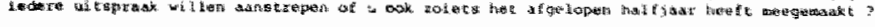

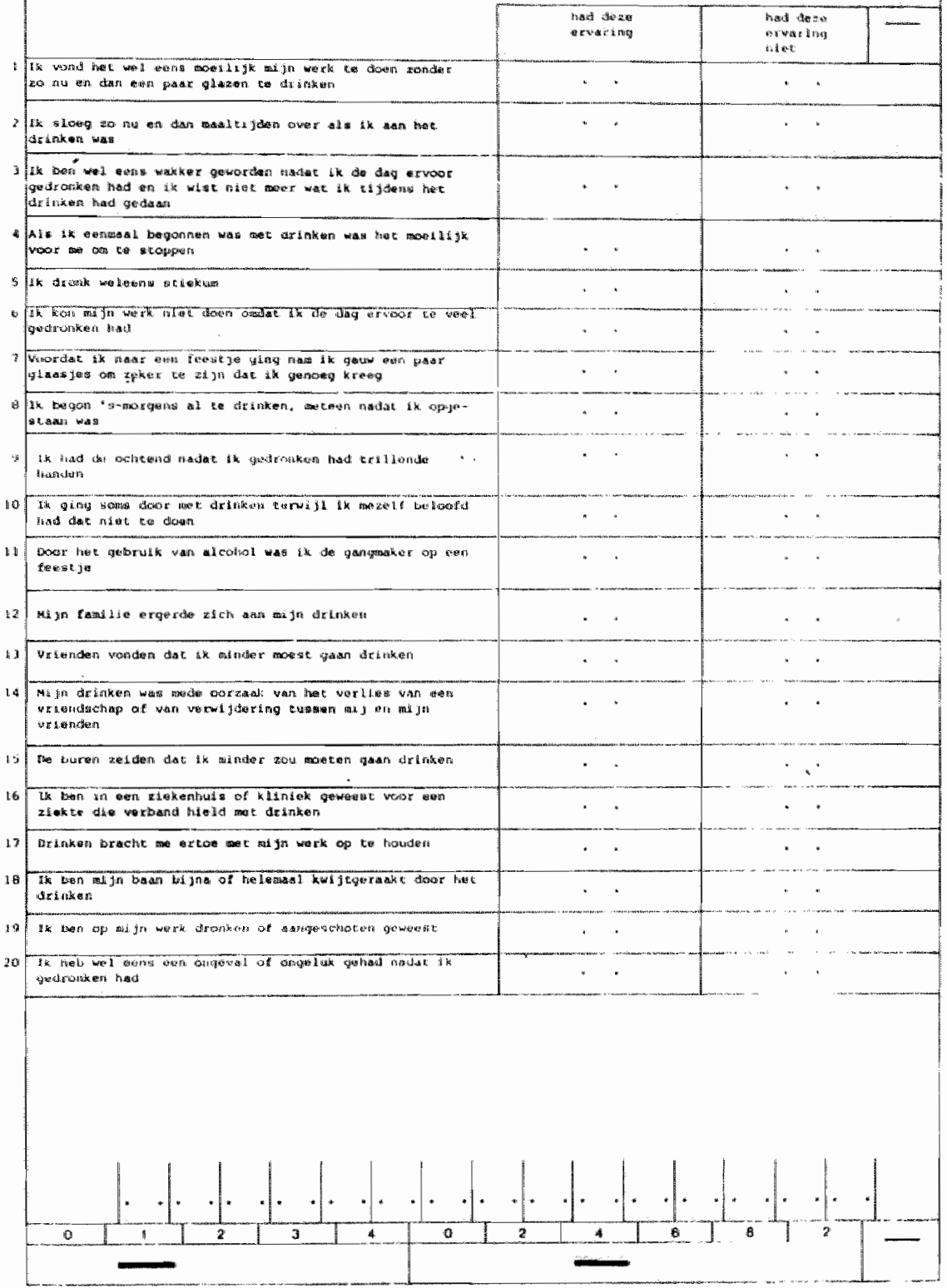


IN⿴囗十⺝

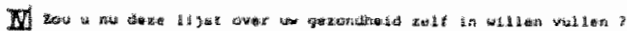

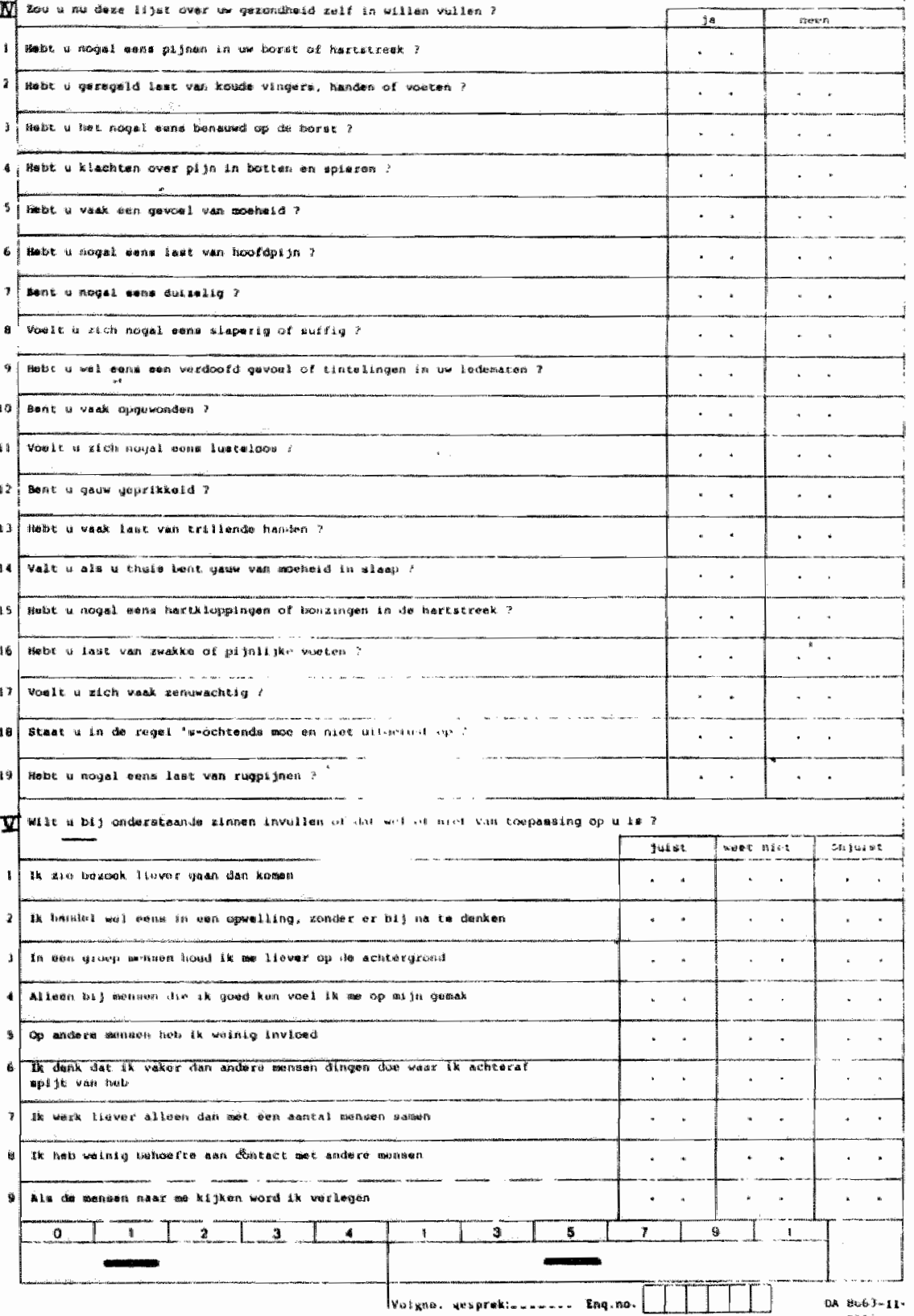




\section{DANKWOORD}

Professor dr. Marla J. Drop wil ik mijn dank betulgen voor de conscientieuse en persoonlijke wijze waarop ze mij heeft begeleid. Haar begeleiding heeft sterk bijgedragen aan het plezler in het werk en aan de vergeleken met eerdere versles, helderder opbouw en preciesere formulering van dit elndprodukt.

Professor dr. F. Sturmans en Prof.dr. J. Casselman, ben $1 \mathrm{k}$ zeer erkentelijk voor de positieve kritiek en konkrete adviezen die zif hebben gegeven.

Deze studie zou in zijn huidige vorm niet mogelijk zijn zonder de toesterming van de G.G. \& G.D- Rotterdam, afdeling G. V.O., on de onderzoeksgegevens van Rotterdam te gebrulken. Bij deze w1l $1 \mathrm{k}$ mijn erkentelljkheld betulgen voor de toesteming.

Kollega-onderzoeker Henk Garretsen in Rotterdam ben 1k dankbaar voor de vruchtbare wijze waarop we hebben samen gewerkt.

Professor dr. G. Saenger, die nauw betrokken is geweest bif het onderzoek in Limburg en Rotterdam, ben $1 \mathrm{k}$ zeer dankbaar voor de wijze waarop hif de samenwerking vorm en tnhoud heeft weten te geven.

Dr. J. Diederiks en A. Volovics van respektievelijk de capaciteltsgroep medische sociologle en medische informatika en Statistlek ben ik dank verschuldigd voor de bruikbare adviezen.

Ir. A. Muytjens wil ik blj deze hartelijk danken voor de ultwoering van de logit-analyse,

$\mathrm{Na}$ de auteur, is het Sylvia Nelk geweest die het proefschrift het meest onder ogen heeft gehad. Ik ben haar zeer erkentel1jk voor de inzet waarmee ze de tekst voor dit. proefschrift heeft verzorgd. Marjoke Arkenbout en Laura van Gytenbeek hebben geassisteerd bif de verzorging van de tabellen.

Truus custers heeft als onderzoeksassistente en kamergenote op velerle1 wijze bifgedragen aan het onderzoek, waarvoor $1 \mathrm{k}$ haar zeer dankbaar ben. Mieke Derickx heeft meegewerkt om de tekst op tijd bif de drukker te krljgen. Marga Doyle heeft waardevolle teikstadviezen gegeven voor de summary. Grote waardering heb lk ook voor de hulp die Henk Lebens bij het werken aan de computer heeft geboden. 
Ger van Wunnlk heeft de flguren verzorgd en advlezen voor tekstverzorging gegeven, warvoor miln dank.

Frank van Helfteren heeft de onslag verzorgd. De zekerheid van een zo goed verzorgde omslag heeft bljgedragen aan het plezler bij het afwerken van het proefschrift. 


\section{CURRICULUIM VITAE}

Ik ben geboren op 26 juni 1947 in Amsterdam.

De lagere en middelbare school heb ik in Utrecht doorlopen. Na beëindiging van de middelbare school heb ik een jaar gewerkt. In 1967 ben ik de studie soclologie aan de Rljksuniversiteit van Leiden begonnen. In deze disclpline ben ik in 1975 in Leiden afgestudeerd met als hoofdvak wljsgerlge sociologie, als bifvakken emptriese sociologie en sociale flilosofle.

TIjdens mijn studie heb ik ook aktlvitelten op ander gebled ontploold. Eén van deze aktiviteiten -koördinatie en koken in respektievelijk de Groene Waterman te Utrecht en de Maretak in Maastricht- heeft mij van begin 1975 tot midden 1980 ook als bron van inkomsten gediend.

Vanaf 1980 ben ik werkzaam bij de Rijksuniversitelt Limburg, capaciteitsgroep mediese sociologie. 